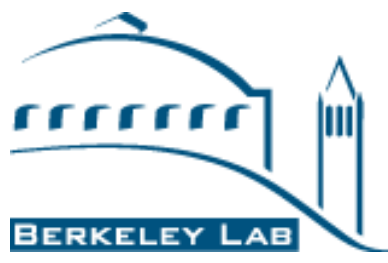

ERNEST DRLANDI LAWRENCE

BERKELEY NATIRNAL LABGRATRRY

\title{
Development of Hydrologic Characterization Technology of Fault Zones: Phase I, 2nd Report
}

Kenzi Karasaki, Celia Tiemi Onishi, Bill Black and Sebastien Biraud

Earth Sciences Division, Lawrence Berkeley National Laboratory

March 2009

NUMO-LBNL Collaborative Research Project Report 
This document was prepared as an account of work sponsored by the United States Government. While this document is believed to contain correct information, neither the United States Government nor any agency thereof, nor the Regents of the University of California, nor any of their employees, makes any warranty, express or implied, or assumes any legal responsibility for the accuracy, completeness, or usefulness of any information, apparatus, product, or process disclosed, or represents that its use would not infringe privately owned rights. Reference herein to any specific commercial product, process, or service by its trade name, trademark, manufacturer, or otherwise, does not necessarily constitute or imply its endorsement, recommendation, or favoring by the United States Government or any agency thereof, or the Regents of the University of California. The views and opinions of authors expressed herein do not necessarily state or reflect those of the United States Government or any agency thereof, or the Regents of the University of California. 


\section{Executive Summary}

This is the year-end report of the 2nd year of the NUMO-LBNL collaborative project: Development of Hydrologic Characterization Technology of Fault Zones under NUMO-DOE/LBNL collaboration agreement, the task description of which can be found in the Appendix 3.

Literature survey of published information on the relationship between geologic and hydrologic characteristics of faults was conducted. The survey concluded that it may be possible to classify faults by indicators based on various geometric and geologic attributes that may indirectly relate to the hydrologic property of faults. Analysis of existing information on the Wildcat Fault and its surrounding geology was performed. The Wildcat Fault is thought to be a strike-slip fault with a thrust component that runs along the eastern boundary of the Lawrence Berkeley National Laboratory. It is believed to be part of the Hayward Fault system but is considered inactive.

Three trenches were excavated at carefully selected locations mainly based on the information from the past investigative work inside the LBNL property. At least one fault was encountered in all three trenches. Detailed trench mapping was conducted by CRIEPI (Central Research Institute for Electric Power Industries) and LBNL scientists. Some intriguing and puzzling discoveries were made that may contradict with the published work in the past. Predictions are made regarding the hydrologic property of the Wildcat Fault based on the analysis of fault structure. Preliminary conceptual models of the Wildcat Fault were proposed. The Wildcat Fault appears to have multiple splays and some low angled faults may be part of the flower structure.

In parallel, surface geophysical investigations were conducted using electrical resistivity survey and seismic reflection profiling along three lines on the north and south of the LBNL site. Because of the steep terrain, it was difficult to find optimum locations for survey lines as it is desirable for them to be as straight as possible. One interpretation suggests that the Wildcat Fault is westerly dipping. This could imply that the Wildcat Fault may merge with the Hayward Fault at depth. However, due to the complex geology of the Berkeley Hills, multiple interpretations of the geophysical surveys are possible. 
An effort to construct a 3D GIS model is under way. The model will be used not so much for visualization of the existing data because only surface data are available thus far, but to conduct investigation of possible abutment relations of the buried formations offset by the fault. A 3D model would be useful to conduct 'what if' scenario testing to aid the selection of borehole drilling locations and configurations.

Based on the information available thus far, a preliminary plan for borehole drilling is outlined. The basic strategy is to first drill boreholes on both sides of the fault without penetrating it. Borehole tests will be conducted in these boreholes to estimate the property of the fault. Possibly a slanted borehole will be drilled later to intersect the fault to confirm the findings from the boreholes that do not intersect the fault.

Finally, the lessons learned from conducting the trenching and geophysical surveys are listed. It is believed that these lessons will be invaluable information for NUMO when it conducts preliminary investigations at yet-to-be selected candidate sites in Japan. 


\section{Table of Contents}

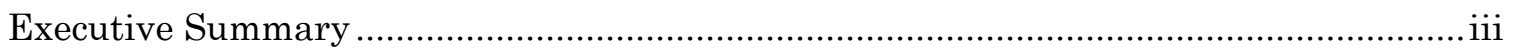

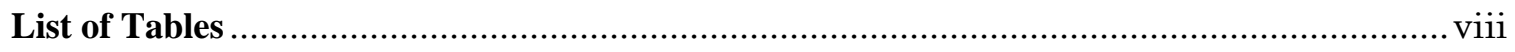

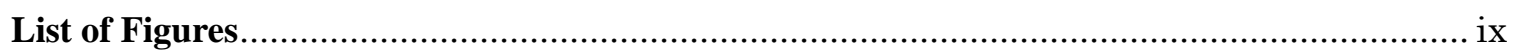

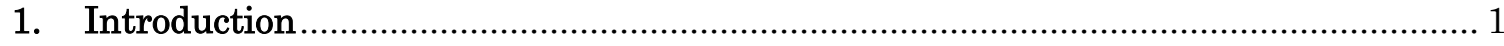

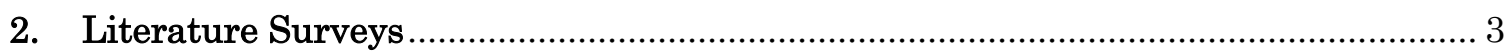

2.1. Relationship between Geologic and Hydrologic Characteristics ........................... 3

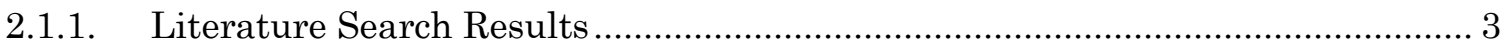

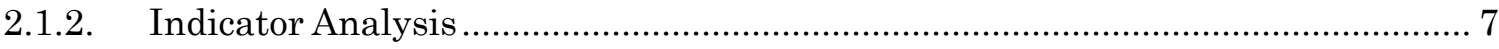

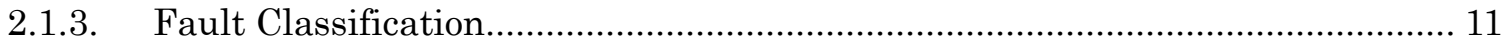

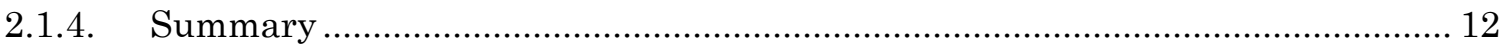

2.2. Procedure Development for Investigation and Characterization .......................... 23

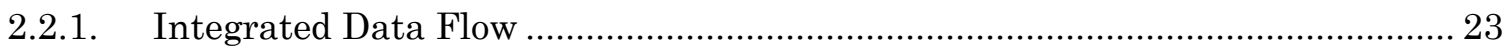

2.2.2. Hydrologic Investigation/Characterization Flow for Fault Zones...................... 23

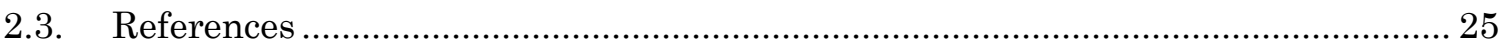

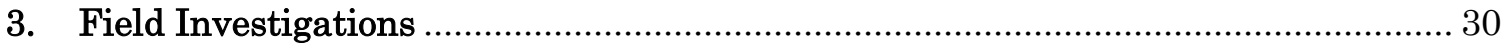

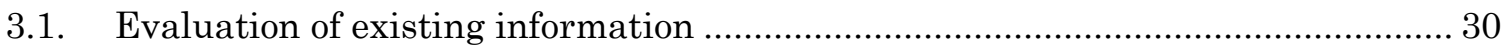

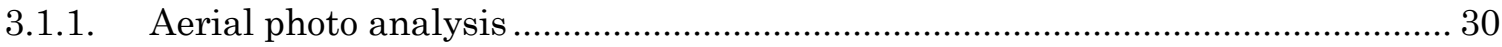

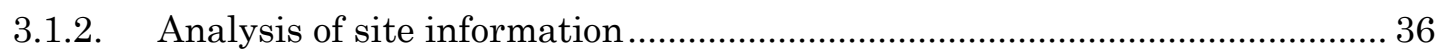

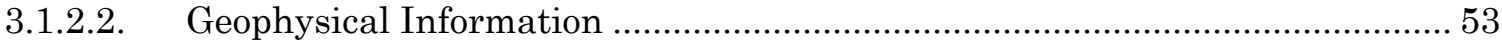

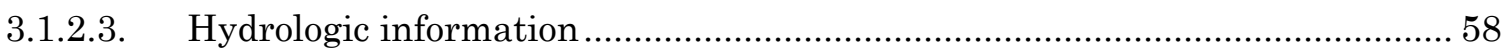

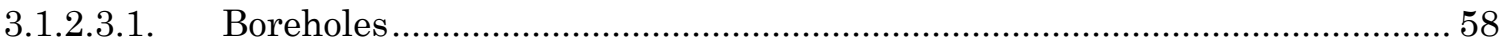

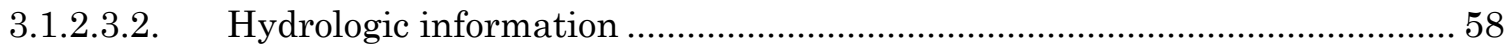

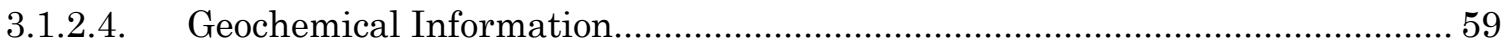

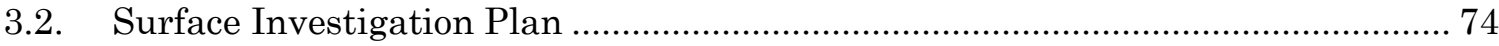

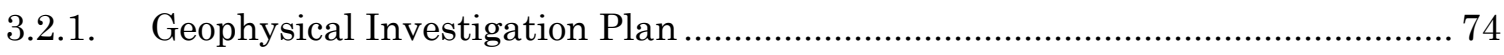

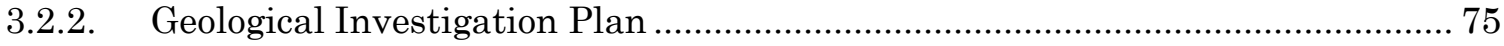

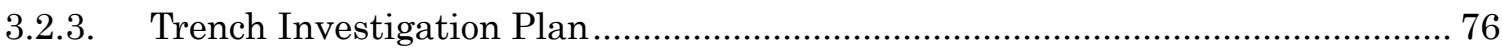

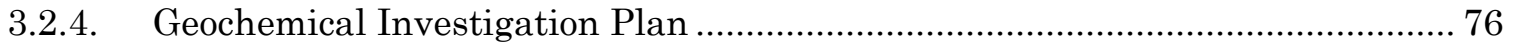




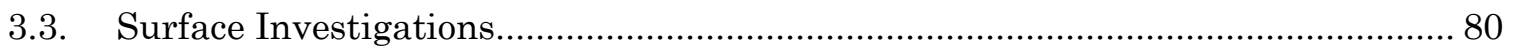

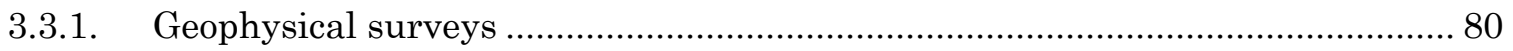

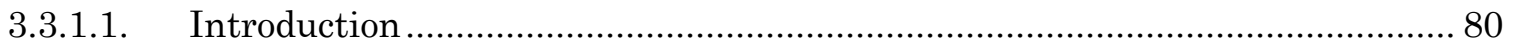

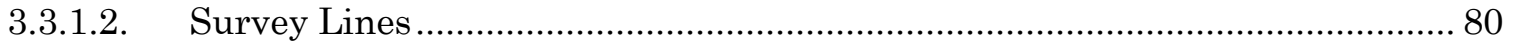

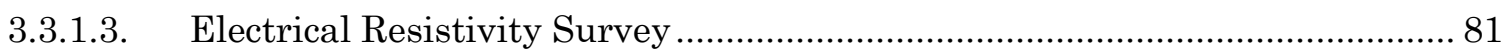

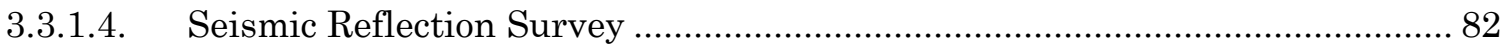

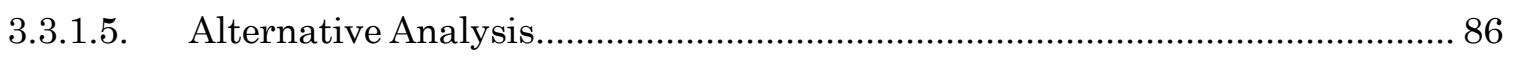

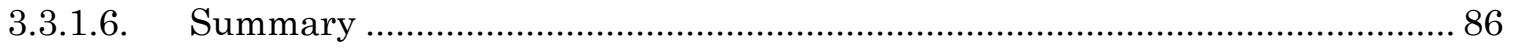

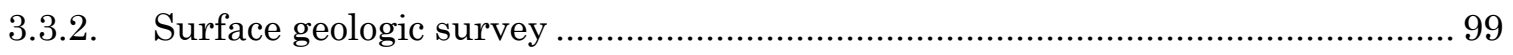

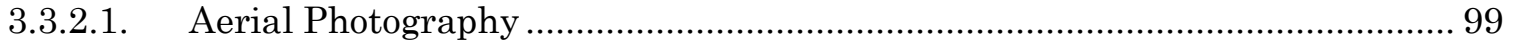

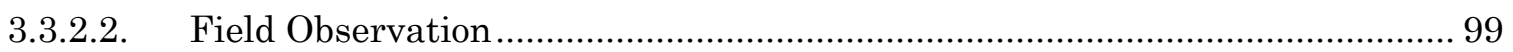

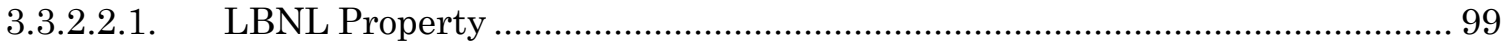

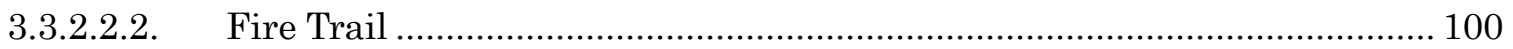

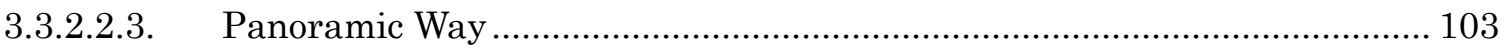

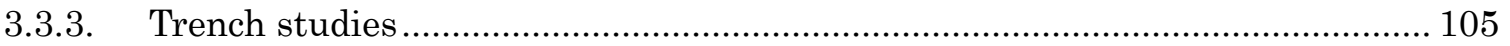

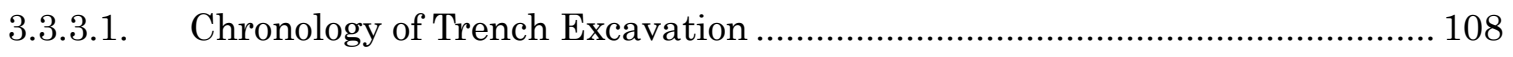

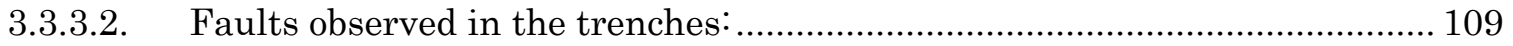

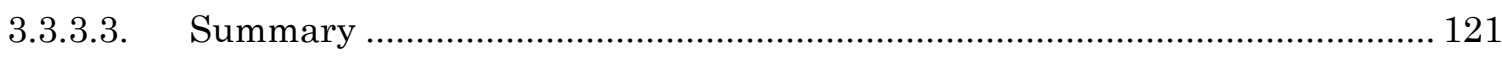

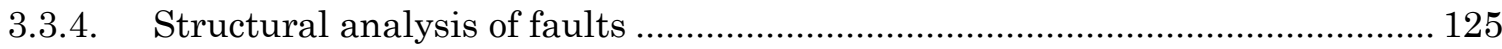

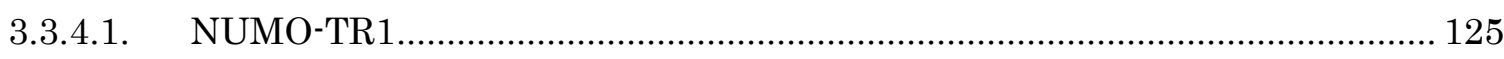

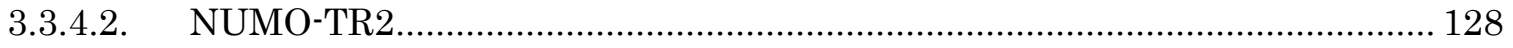

3.3.4.2.1. Fault Fracture Zone and Surrounding Deformation Structure ................. 128

3.3.4.2.2. $\quad$ Predicted Hydrologic Properties.................................................................... 129

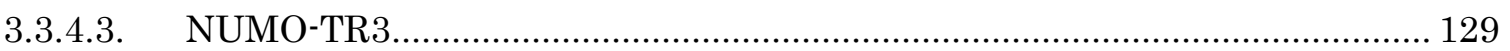

3.3.4.3.1. Fault Fracture Zone and Surrounding Deformation Structure ................. 129

3.3.4.3.2. Predicted Hydrologic Properties..................................................................... 129

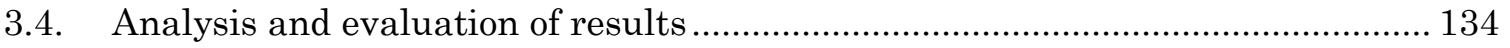

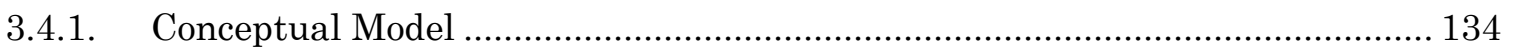

3.4.1.1. Conceptual model by Kiho et al.(2009) ......................................................... 134

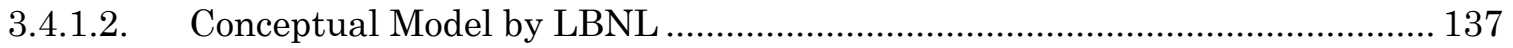




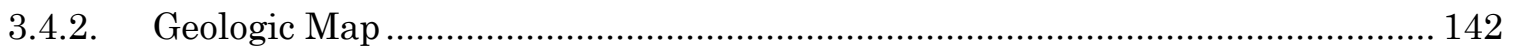

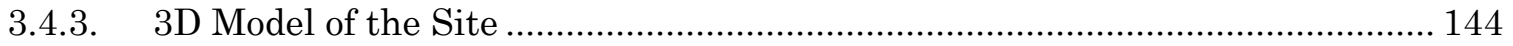

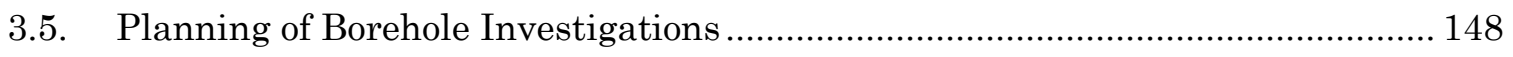

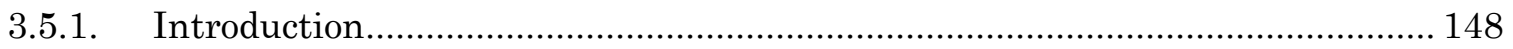

3.5.2. Borehole Drilling Plan............................................................................... 148

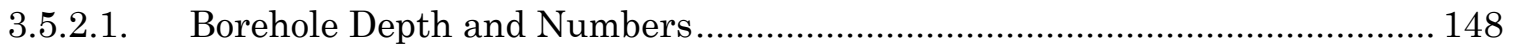

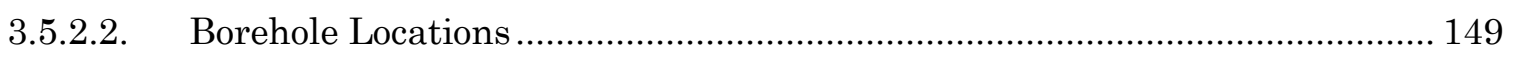

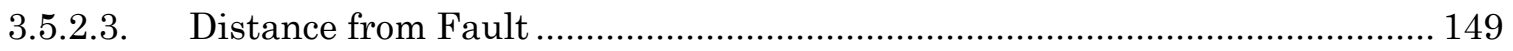

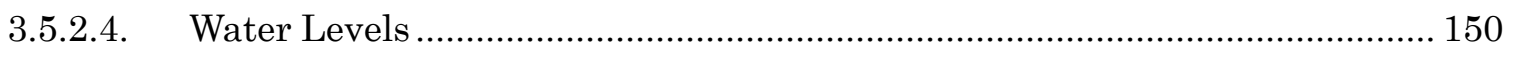

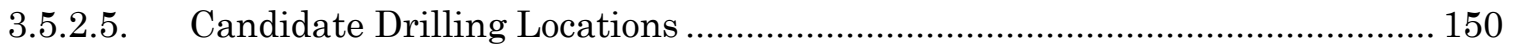

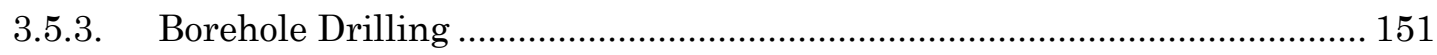

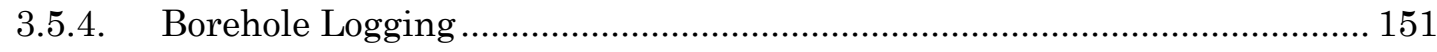

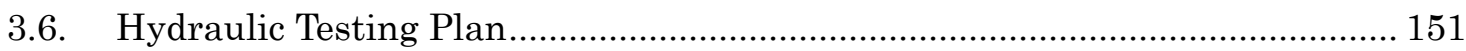

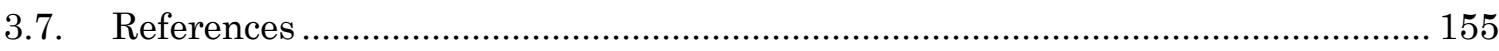

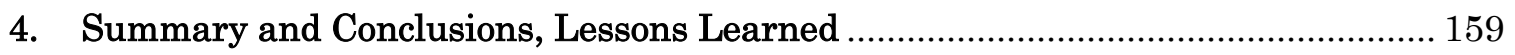

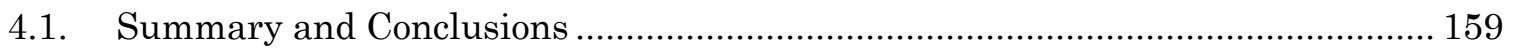

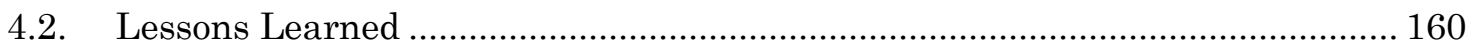

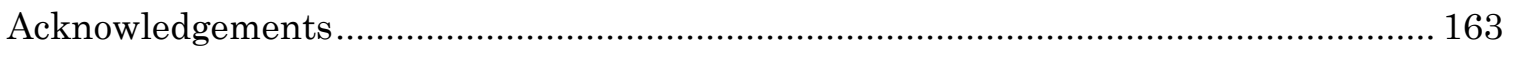

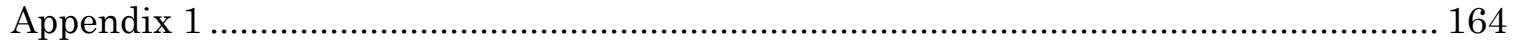

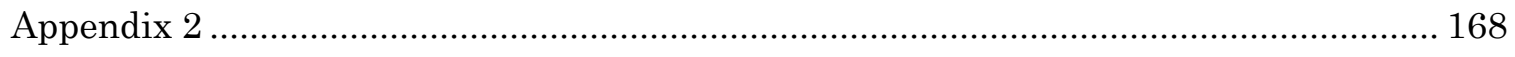

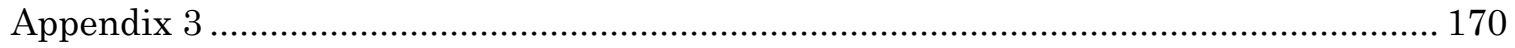

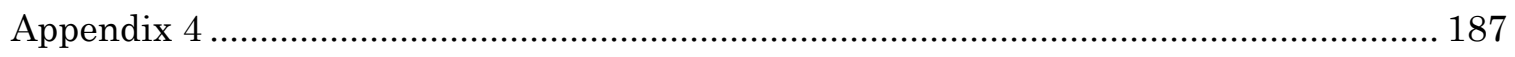




\section{List of Tables}

Table 2-1 Attributes used for indicator analysis and fault structures (Kiho et al., 2009)

Table 2-2 Correlations between the indicators and fault attributes and notable features (Kiho et al., 2009).

Table 2-3 Relationship between geologic and hydrologic characteristics (relative to position within a fault system), Kiho et al. (2009).

Table 2-4 Relationship between geologic and hydrologic characteristics (relative to fault type), Kiho et al. (2009)................................................................................ 14

Table 2-5 Relationship between geologic and hydrologic characteristics (relative to fault development stage), Kiho et al. (2009).

Table 2-6 Relationship between geologic and hydrologic characteristics (relative to

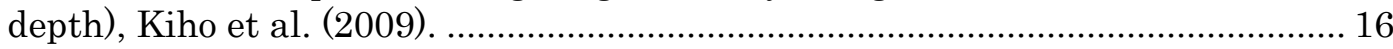

Table 2-7 Relationship between geologic and hydrologic characteristics (relative to protolith rock type), Kiho et al. (2009)

Table 2-8 Relationship between geologic and hydrologic characteristics (relative to material type), Kiho et al. (2009).

Table 2-9 Relationship between geologic and hydrologic characteristics (relative to regional stress field and hydrothermal alteration), Kiho et al. (2009).................. 19

Table 2-10 Type classification of faults (Kiho et al., 2009) .......................................... 20

Table 3-1 List of identified lineaments. (Kiho et al., 2009) ........................................ 35

Table 3-2. Well information near the Wildcat Fault （Modified from LBNL, 2000）.61 


\section{List of Figures}

Figure 2-1 Flow diagram for type classification determination. (Kiho et al., 2009) ..... 21

Figure 2-2 Application example of fault type classification. (Kiho et al., 2009) ....................... 22

Figure 2-3 Data flow diagram for fault distribution and characteristics that affect

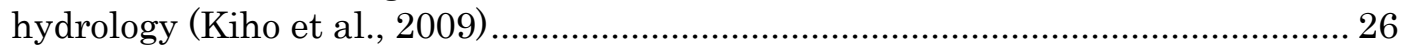

Figure 2-4 Data flow diagram for hydrologic characterization (Kiho et al., 2009) ...... 27

Figure 2-5 Proposed approach to hydrologic characterization of faults. (Kiho et al., 2009) 28

Figure 2-6 Investigation flow diagram for hydrologic characterization of faults. (Kiho et

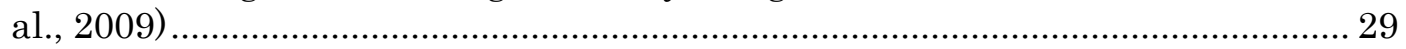

Figure 3-1 Aerial photo analysis area by Kiho et al. (2009) ......................................... 31

Figure 3-2 Lineaments associated with the Hayward Fault system (1). (Kiho et al.,

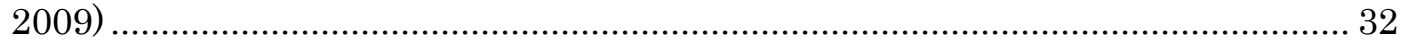

Figure 3-3 Lineaments associated with the Hayward Fault system (2). (Kiho et al.,

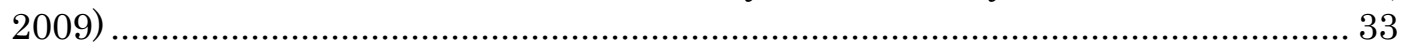

Figure 3-4 Lineaments associated with the Hayward Fault system (3). (Kiho et al.,

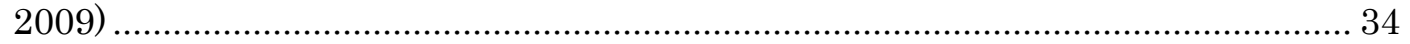

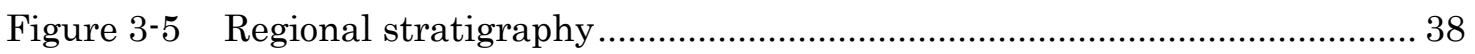

Figure 3-6. Faults and plate motions in the San Francisco Bay Region (USGS). Yellow lines show the location of two major earthquakes.............................................. 42

Figure 3-7. Displacement of the U.C. Berkeley Memorial Stadium wall as a result of the movement of the Hayward Fault ........................................................................ 43

Figure 3-8. Top: LIDAR image (top) from USGS showing the trace of the Hayward Fault crossing the Memorial Stadium and displaced streams. Source: http://pubs.usgs.gov/fs/2008/3019/fs2008-3019.pdf. .... 44

Figure 3-9. Locations of geotechnical boreholes near Bldg. 74(Subsurface consultants, 1994). 51

Figure 3-10. Borehole log of G-13 that encounters the Claremont chert formation and a claystone formation below it (Subsurface Consultants, 1994) ............................ 52

Figure 3-11 Seismic refraction lines conducted in the East Canyon. (Geo/Resource, 1994) 54

Figure 3-12 Magnetometer Survey in the East Canyon Area (Geo/Resource

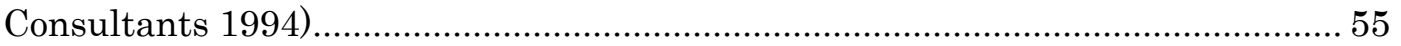

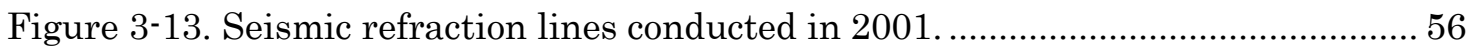

Figure 3-14. Seismic refraction profile form Line 1 (top) and Line 2 (bottom)............ 57 
Figure 3-15. LBNL site map with topography and the Widcat Fault trace. 62

Figure 3-16 LBNL geologic map superimposed with suspected fault traces, borehole

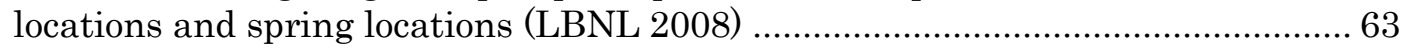

Figure 3-17 Mechanism for spring occurrence (木方他、2009） ....................................64

Figure 3-18. Existing monitoring well locations near the Wildcat Fault. Enlarged section from Figure 3-15..... 65

Figure 3-19. Water level contour near the Wildcat Fault (Modified from LBNL, 2000). 66

Figure 3-20 Krieged contour map of water levels in boreholes. (Kiho et al., 2009).................... 67

Figure 3-21 Krieged contour map of borehole elevations. (Kiho et al., 2009) ..............67

Figure 3-22. Rainfall data and water level in MW74-94-8. (fromLBNL 2008) ............ 68

Figure 3-23. Rainfall data and water level in MW74-95-6. (from LBNL-2008) ............ 69

Figure 3-24. Permeability of various geologic units measured by pump tests and slug

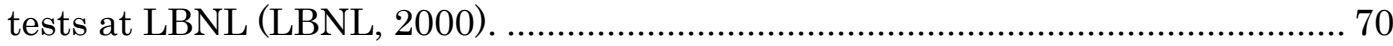

Figure 3-25. Stiff diagrams of geochemical compositions in the monitoring wells near

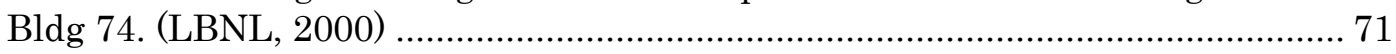

Figure 3-26 Principal component analysis of major dissolved ions. (Kiho, et al., 2009) 72

Figure 3-27. Historical springs near the Wildcat Fault................................................ 73

Figure 3-28 WLA and NUMO trench locations (Modified from William Lettis

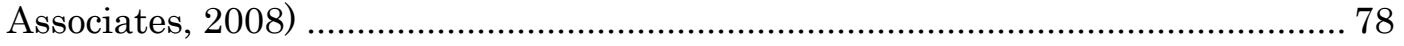

Figure 3-29 Contour map around the LBNL property and the Fire Trail. .................. 79

Figure 3-30. Supersting and Swift data acquisition system by AGI.......................... 81

Figure 3-31. Geode seismic system (left, yellow) and 40Hz geophone by Mark Products (right, orange) (Norcal Geophysics, 2009) .............................................................. 83

Figure 3-32. Accelerated weight drop system mounted on an ATV (Black, 2009)....... 83

Figure 3-33. Geophysical survey lines Line 1 to the north and lines 2 and 3 to the south of LBNL property. Green broken line denotes LBNL property line. ..................... 87

Figure 3-34. Enlarged view of Figure 3-33. Geophysical survey lines Line 1 to the north

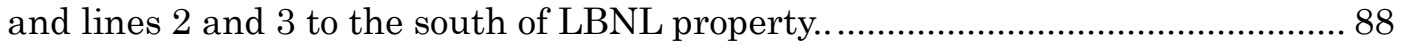

Figure 3-35. Further enlarged view of the survey lines 1, 2 and 3 for electrical

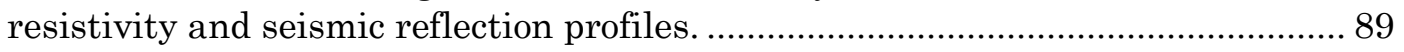

Figure 3-36. Electrical resistivity profiles for Line 1(top), 2 (middle) and 3 (bottom).. 90

Figure 3 -37. Interpreted seismic reflection profile from Line 1 ............................... 91 


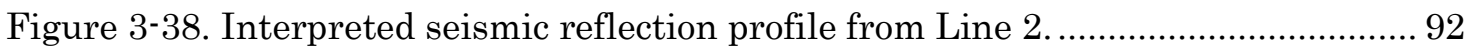

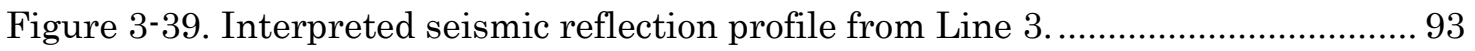

Figure 3-40. Superimposed plot of electrical resistivity and seismic reflection profiles

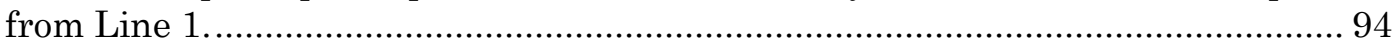

Figure 3-41. Superimposed plot of electrical resistivity and seismic profiles from Line

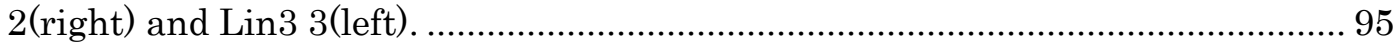

Figure 3-42. Alternative interpretation for Line 1 by Catchings (2009). .................... 96

Figure 3-43. Alternative interpretation for Line 2 by Catchings $(2009)$..................... 97

Figure 3-44. Alternative interpretation for Line 3 by Catchings (2009). ..................... 98

Figure 3-45. Weathered and fractured volcanics of the Moraga Formation ............... 100

Figure 3-46. Overturned beds of cherts and siltstone of the Claremont Fm, Fire Trail,

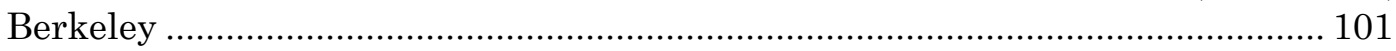

Figure 3-47. Outcrop of bedded Claremont chert and siltstone along the Fire Trail,

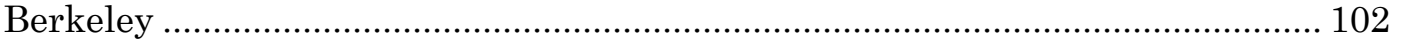

Figure 3-48. Outcrop of typical mottled weathered reddish and greenish siltstone of Orinda formation in the Fire Trail, Berkeley ..................................................... 103

Figure 3-49. Sub-horizontal slickensides in Cleramont chert .................................. 104

Figure 3-50. Proposed location of Trench TR0. On the north wall, the contact between cherts in the $\mathrm{E}$ and sandstone in the $\mathrm{W}$ follows the approximate location of the red dotted line. 106

Figure 3-51. Trench TR0 after filled, and location of trench TR1 ............................. 106

Figure 3-52. View from the Fire Trail of three open NUMO trenches. The lengths of NUMOTR01 and TR02 are approximate. Centennial Road and Building 74 are used as point of reference. 107

Figure 3-53. View to the east of trench NUMO TR1 before hydraulic shoring was placed. 109

Figure 3-54. Trench log of NUMO TR1 by Kiho et al (2009) ...................................... 110

Figure 3-55. View to the east of trench NUMO TR2 near the north gate to the Fire trail. .111

Figure 3-56. Main fault in NUMOTR2 showing main deformation concentrated in the Orinda Fm. 112

Figure 3-57. Clay gouges in faulted Orinda Formation 113

Figure 3-58. Several subvertical and subparallel dark seams observed in the sandstone 113

Figure 3-59. Mosaic of fault observed in the middle of NUMO TR2 114 
Figure 3-60. Scaly cleavage observed in dark-red mudstone, showing fine slickenside on cleavage plane 115

Figure 3-61. Sketch of Trench NUMO TR2. The main fault was observed in the west end of the trench. The fault is the contact between the sandstone of the Sobrante/Claremont Formation and the siltstone and mudstone of the Orinda Formation. 116

Figure 3-62. View to the east of the trench NUMOTR3 117

Figure 3-63. West view to NUMO TR3. Note the sharp fault contact between the Orinda and Claremont Formations. 118

Figure 3-64. Example of intrusive sandstone dike observed in cherts of the Claremont Formation. 119

Figure 3-65. Sketch of Trench NUMO TR3, showing the main fault contact between siltstone in the west and the cherts in the east. 120

Figure 3-66. Sketch of the north face of NUMO-TR1 125

Figure 3-67. Picture of the exposed fault in NUMO-TR1. The solid line is the boundary between the bedrock and the alluvium and the broken lines show estimated boundary of the fault rock. 127

Figure 3-68. Sketch of the north wall of NUMO-TR2. (Kiho et al, 2009). 130

Figure 3-69. East and bottom wall of NUMO-TR2. Yellow box shows the location Block Sample E was taken. (Kiho et al, 2009). 131

Figure 3-70. Block Sample E showing the details of Fa-1. (Kiho et al, 2009) 131

Figure 3-71. Cross sectional views of Block Sample E by CT scanner. (Kiho et al, 2009)

Figure 3-72. Photo and sketch of the north face of NUMO-TR3. (Kiho et al, 2009) ... 133

Figure 3-73. Conceptual model of the Wildcat Fault structure by Kiho et al(2009).. 136

Figure 3-74. General characteristics of strike-slip fault systems in plan view: (a) Bends in the fault surface produce localized zones of extension and subsidence, whereas restraining bends produce localized zones of contraction and uplift; (b) Stepovers between two offset fault systems produce either pull-apart basins for releasing stepovers or pop-ups and uplifts for restraining stepovers. 137

Figure 3-75. Analog model showing the complex structure generated during strike-slip faulting..... 138

Figure 3-76. Geologic cross section of the East Bay showing the flower structure of the Hayward fault and the relationship with the Wildcat and Moraga faults (Graymer, 2000) 139

Figure 3-77. Cartoon illustrating fault geometry at depth at Panoramic Way.......... 140

Figure 3-78. Illustration of the conceptual model of faults within LBNL property. The 
box in red represents trench locations.

Figure 3-79. Geologic map of the Wildcat Fault, Berkeley California ......................... 143

Figure 3-80. A 3D GIS model of the LBNL area with vertical exaggeration............... 146

Figure 3-81. A view to the east of the Wildcat Fault plane. ...................................... 147

Figure 3-82 A view to the north of the cross-section perpendicular to the Wildcat Fault.

Figure 3-83. Potential borehole locations and existing deep boreholes SSL-1 and SSL-2 in relation to the Wildcat Fault. 153

Figure 3-84. Hayward Fault (red) and Wildcat Fault (white). Symbols show where a fault is encountered along the Wildcat Fault Green squares show potential drilling locations outside LBNL property. 154 


\section{Introduction}

The Nuclear Waste Management Organization of Japan (NUMO) and the Department of Energy of the United States of America (DOE) established a cooperative agreement in the field of radioactive waste management on July 10, 2002. In May 2005, NUMO and the Regents of the University of California as the DOE Management and Operating Contractor for the Ernest Orlando Lawrence Berkeley National Laboratory (LBNL) entered into an agreement to collaborate, and for LBNL to conduct work under the auspices of the bilateral agreement.

In 2006, ANRE (Agency for Natural Resources and Energy) jointly with JAEA (Japan Atomic Energy Agency) identified outstanding technological issues and needs regarding the research and development for geologic disposal of HLW subsequent to the publication of the Second Progress Report by JNC (Japan Nuclear Cycle Development Institute) in 1999. Research organizations in Japan as well as NUMO have been conducting investigations on these issues and needs. In the area of groundwater hydrology, four R\&D needs were identified and are currently being investigated: improvement of groundwater flow characterization technology, development of testing and characterization technology in coastal areas, development of testing equipment and technology, and field application of testing and characterization technology. NUMO has been incorporating the results of the outcome of these R\&Ds as they become available and are deemed appropriate, and is in the process of systematizing the testing and characterization technology to form a solid technical foundation for selecting the sites for detailed investigation.

The first NUMO-LBNL collaborative project was entitled "Feature Detection, Characterization and Confirmation Methodology," which was designed to further develop radioactive waste management technologies related to an investigation strategy and technology for detection, characterization, and confirmation of key geologic features at possible nuclear waste repository sites. The project was carried out from May 2005 through March 2007. Among other important findings, the study has identified the hydrologic properties of fault zones as one of the most important parameters that need to be evaluated during the preliminary investigation stage. Based on the lessons learned at the Mizunami and Horonobe URLs, as well as at numerous mines, dams, and tunnels - and given the geologic environment of the Japanese Islands - faults are likely to exist almost ubiquitously, which 
need to be assessed both at the preliminary and the detailed investigation stage (the length scale of the faults of interest would range from several kilometers in the former down to several hundred meters in the latter). However, none of the four R\&D activities mentioned above sufficiently addresses the development of systematized hydrologic characterization technology specifically tailored for fault zones. At present, it is necessary to use perhaps overly conservative values for the hydrologic parameters of fault zones for the design and performance assessment of a repository. Therefore, development of a more efficient and reliable fault-zone characterization technology is highly desirable. The geologic properties of faults and the relationships among their geometry, type, fault parameters, and internal structures are being investigated mostly overseas. Hydrologic investigation of faults of various sizes are also being conducted at foreign as well as at domestic characterization sites. However, the relationship between the geologic and hydrologic properties of faults is not yet studied sufficiently.

In light of the above recognition, NUMO and LBNL entered an agreement for LBNL to conduct a study entitled "Development of Hydrologic Characterization Technology of Fault Zones" in August 2007. For FY2007, the objectives of the study was to organize the information available from overseas to ultimately establish an efficient and systematized methodology for hydrologic investigation and characterization of faults at the scale of interest during the preliminary investigation stage for more practical design and performance assessment. LBNL's study (Karasaki et al, 2008) concluded that there is very little available in the literature that relates the geologic structure of faults to hydrology, that it still may be feasible to classify faults based on geologic attributes to predict their hydrologic characteristics, and that it is critical to establish field investigation technology of fault zone hydrology. In July 2008, NUMO and LBNL agreed to continue the project and develop a field site to study fault zone hydrology. This report is a summary of the study conducted by LBNL from August 2008 through March 2009. The study is conducted as a collaborative study between NUMO and USDOE/LBNL. It should be possible to apply/transfer the results of the study obtained at a site in the West Coast of the United States, whose tectonic environment is just as active as that in Japan, to the Japanese repository program when they will be needed. These actions should also be beneficial to the U.S. program in the long run. 


\section{Literature Surveys}

\subsection{Relationship between Geologic and Hydrologic Characteristics}

木方他(2009)は既往文献資料に基づく断層の地質特性と水理特性に関するデータ収集，整理. 解析を行い, 断層の地質特性から間接的に水理特性を推定できる可能性について検討している。 本節では木方他(2009)の要約を記述する。

木方他(2009) らは文献については、国内で施工されたダム，トンネル，原子力発電所等の工 事誌及び申請書，S K B 等海外の H L Wサイト調査に関連した調査·研究事例のほか，断層構造 の特徴，断層構造と水理特性の関係等に着目した研究論文を対象としている。著さした文献・ 資料は全部で 749 資料であり，このうち，断層構造及び水理特性に着目して記載内容を確認し た資料は 620 資料に及んでいる。

\subsubsection{Literature Search Results}

木方他(2009)は調査した文献の記載内容を以下の 6 つの着眼点に基づいて整理している。

(1)：断層系全体からみた位置

(2) : 断層型

(3) : 断層系の発達段階

(4) : 深さ

(5) : 母岩の岩種

（6：熱水変質作用による影響

さらに、木方他(2009)は各々の着眼点の整理結果を次のようにまとめている。

(1) 断層系全体からみた位置

【構成物とその組み合わせ】

・断層構成物とその組み合わせには多様性があり，大局的には，断層系の中央部 で 14 パターン, 分岐・会合部及び㕍行部で 7 パターン, 端部で 2 パターンの組 み合わせからなり，全体で 17 パターンに区分できる。

・位置に係らず，断層構成物とその組み合わせは，「母岩/ダメージゾーン/断層核 (破砕帯/ガウジ/破砕帯) /ダメージゾーン/母岩」（破砕帯，ガウジを伴わない 場合もある）からなり，断層構造としては対称性が認められるものが多い。

\section{【幅】}


・断層核（ガウジ含む）及びダメージゾーンの幅は，断層系の中央部で大きく， 分岐・会合部及び雁行部で小さい。

・ただし，断層核とダメージゾーンの幅の比率に着目すると，断層系の中央部で は断層核の比率が大きく, 雁行部及び端部ではダメージゾーンの比率が大きく なる傾向が認められる。

\section{【連続性】}

- 大局的にみると, 断層核の連続性はあまり良くなく, 位置による明瞭な差異は 認められない。中央部の連続性は㕍行部よりやや良い傾向がある。(むしろ, 累 積変位量と相関が良く, 変位量が大きいほど連続性が良い傾向が認められる。

・ダメージゾーンの 連続性は良い。

\section{【透水性】}

・ 断層ガウジは低透水性, ダメージゾーンは高透水性を有する。断層ガウジの有 無が断層横断方向の透水性に大きな影響を与える。

・一般的に, 断層はセグメントごとに遮水性（ガウジを有する場合）を有するが, ダメージゾーンが発達するリレー部（分岐・会合部, 雁行部）では高い透水性 を有し地下水の広域流動を可能としている。

(2) 断層型

\section{【構成物とその組み合わせ】}

・断層の構成物とその組み合わせには多様性があり, 大局的には, 正断層では 3 パターン，逆断層では 7 パターン，横ずれ断層では 11 パターンの組み合わせか らなり，全体で 16 パターンに区分できる。

・断層型に係らず, 断層の構成物とその組み合わせは, 「母岩/ダメージゾーン/断 層核（破砕帯/ガウジ/破砕帯）/ダメージゾーン/母岩」(破䂗帯, ガウジを伴わ ない場合もある) からなり，断層構造としては対称性が認められるものが多い。

\section{【幅】}

・ 断層型の違いと断層の幅に明膫な関倸は認められない。しかし, ダメージゾー ンについては，逆断層より正断層の方が厚い傾向が認められる。

\section{【連続性】}

・断層ガウジは膨縮する傾向があり，その連続性はあまり良くない。

・ダメージン゙ーンは, 横ずれ断層で連続性の悪いものもみられるが，全体的には 比較的連続性は良いと考えられる。

\section{【透水性】}

・断層型の違いと透水性には明瞭な関係は認められない。

・断層ガウジは低透水性, ダメージジーンは高透水性を有する。断層ガウジの有 無が断層横断方向の透水性に大きな影響を与える。

・ダメージゾーンでは断層面に平行する水みちが多数存在し, 地下水の広域流動 
を可能にしている。

(3) 断層系の発達段階

【構成物とその組み合わせ】

・ 断層の発達段階の違いと断層の構成物とその組み合わせには明瞭な特徴は認め られないが, 累積変位量 $1 \mathrm{~m} \sim 100 \mathrm{~m}$ 程度の中規模断層では断層中央部に断層核(ガ ウジ等）が認められる傾向がある。

・断層の構成物とその組み合わせのパターンには多様性が認められる。

【幅】

・断層系の発達段階に応じて, 断層核（ガウジ含む）及びダメージゾーンの幅は ともに大きくなる。

\section{【連続性】}

・ 断層ガウジの連続性は, 累積変位量が大きい場合（100m 以上）で良いが，中程 度以下の累積変位量では悪くなる。

・ダメージゾーンの連続性は, 発達段階を通じて良い。

\section{【透水性】}

・ 断層系の発達段階の違いと透水性には明瞭な関係は認められない。

・ 断層ガウジは低透水性, ダメージゾーンは高透水性を有する。断層ガウジの有 無が断層横断方向の透水性に大きな影響を与える。

・ ダメージゾーンでは断層面に平行する水みちが多数存在し, 地下水の広域流動 を可能にしている。

・ 断層ガウジが断層系の中央部に発達するようになる中規模断層では, 断層が遮 水性の特徵を有することもある。

(4) 深さ

\section{【構成物とその組み合わせ】}

・ 断層の構成物とその組み合わせに関する文献・資料は，大深度に関するものが 存在しないが，深さ方向一断層構造が大きく変化するとは考え難い。

\section{【幅】}

・ 深さと断層の幅との関係の有無を示す文献・資料が認められない。

\section{【連続性】}

・ 断層構造は深さ方向に明瞭な差異がないと考えられることから, 連続性に関し ても深さ方向の顕著な差異はないものと考えられる。

\section{【透水性】}

・ 浅所〜中深度では, 断層ガウジと断層角礫での透水性の差異は小さいが, 大深 度では非常に大きい。しかし, どの深度でも, 断層ガウジを含む断層核は, 周 辺の角礫やダメージゾーンよりも透水性が低いため, 遮水層として機能する。 
・ 断層ガウジの有無が断層横断方向の透水性に大きな影響を与える。

・ 地下 $300 \mathrm{~m}$ 以深にある断層は大きな貯留能力を有し, 多量の地下水を供給するこ とがある

(5) 母岩の岩種

【構成物とその組み合わせ】

・未固結堆積物では，断層核（ガウジ含む）は形成されるが，ダメージゾーンは 未発達もしくは識別ができない。

- 非変形・非変成岩と変成・変成岩では, 断層構造, 断層の構成物とその組み合 わせに関する文献・資料はないものの，顕著な違いはないと考えられる。

\section{【幅】}

・未固結堆積物では，断層核（ガウジ含む）は形成されるが，ダメージゾーンは 未発達もしくは識別ができない。

・ 非変形・非変成岩と変成・変成岩では断層の幅に関する文献・資料が認められ ず，その関係は不明である。

\section{【連続性】}

・未固結堆積物では, 断層ガウジは不均一で連続性が良くないが，母岩と未固結 堆積物を境する断層では連続性が比較的よい場合もある。

\section{【透水性】}

・ 断層ガウジの透水性は, 母岩の岩種に係らず極めて低く, その有無が断層横断 方向の透水性に大きな影響を与える。

・ ダメージゾーンの透水性は, 変形・変成岩を母岩にした場合, その岩種により 様々な特性を示す。

・堆積岩において, 逆断層では上盤の水の流れは概ね地層に沿い, 一方, 異なる 帯水層の層序を破る流れは正断層及び亀裂を伝わってのみ流れる。

・ 結晶質岩では, ダメージゾーンは高透水性ゾーンとして機能し, 地下深部まで 達し，地下 $300 \mathrm{~m}$ 以深に大きな貯留能力を持つとされる。

６）熱水変質作用による影響

\section{【透水性】}

・熱水変質作用によって断層破砕帯やダメージゾーンに発達する割目は鉱化作用 を受けて，不透水バリアとして機能する。

・ダメージゾーンは, 熱水活動により割目が充填されるため, 熱水活動がない場 合に比べて透水性が著しく低くなる。

・熱水変質作用の有無に係らず，断層周辺（断層核・ダメージゾーンを含む）の 透水性は，断層活動時に高くなるものの，その後は徐々に低くなる。 


\subsubsection{Indicator Analysis}

木方他(2009)は文献整理の結果に基づき, 解析の指標とすべき着眼点として以下に示す $8 つ$ の要因（要素）を選んでいる。

\section{【断層パラメータ】}

着眼点(1) : 断層系全体からみた位置（要素：中央部，分岐・会合部，雁行部・端部・ 延長部)

着眼点(2) : 断層型（要素 : 正断層, 逆断層, 横ずれ断層）

着眼点(3) : 断層系の発達段階（要素 : 累積変位量）

着眼点(4) : 深さ

\section{【母岩の特性等】}

着眼点(5)：母岩の岩種（要素 : 地質年代，岩種，変成・変形度）

着眼点 (6) : 物性等（要素：透水係数, $\mathrm{P}$ 波速度，断層構造，湧水量，土被り）

着眼点(7):広域応力場

着眼点 8：熱水変質作用

Table 2-1 に木方他(2009)が使用した解析指標の要因と断層構造、物性との組み合わせを示す。 木方他(2009)はこれらの解析指標をもとにして, 国内事例から整理した基礎データ間の相関関 係を把握するために, 着眼点（要因・要素並びに断層構造, 物性等）ごとにグラフを作成し， 作成したグラフから読み取れる断層によるその周辺の水理特性に影響を及ぼす断層構造並びに 母岩及び断層の物性との関係を検討した。Table 2-2 に木方他(2009)らが行ったデータ解析によ る相関性の有無とその特徴を示す。 
Table 2-1 Attributes used for indicator analysis and fault structures (Kiho et al., 2009)

\begin{tabular}{|c|c|}
\hline 着眼した要因 & データ解析のための要素と断層構造等の組み合わせ \\
\hline \multirow{5}{*}{ (1) : 断層系全体からみた位置* } & ·断層の空間的位置－破砕帯幅（及びその頻度分布） \\
\hline & ・断層の空間的位置－粘土状破砕幅（及びその頻度分布） \\
\hline & ・断層の空間的位置ーダメージゾーン幅（及びその頻度分布） \\
\hline & ・断層の空間的位置－透水係数（及びその頻度分布） \\
\hline & ・断層の空間的位置－P波速度（及びその頻度分布） \\
\hline \multirow{3}{*}{ (2) : 断層型* } & ・断層型－破砕帯幅（及びその頻度分布） \\
\hline & ・断層型－粘土状破砕幅（及びその頻度分布） \\
\hline & ・断層型ーダメージゾーン幅（及びその頻度分布） \\
\hline \multirow[b]{2}{*}{ (3) : 断層系の発達段階* } & ・鉛直変位量－破砕帯・粘土状破砕部・ダメージゾーン幅 \\
\hline & $\begin{array}{l}\text { ・水平変位量 (右ずれ・左ずれ) } \\
\text { 一破砕帯幅・粘土状破砕部・ダメージゾーン幅 }\end{array}$ \\
\hline \multirow{3}{*}{ (4) : 深さ* } & \begin{tabular}{|l} 
・断層の深さ一破砕帯幅 \\
(同一断層における深さ一破砕帯幅)
\end{tabular} \\
\hline & ・断層の深さ一粘土状破砕幅 \\
\hline & ・断層の深さーダメージゾーン幅 \\
\hline \multirow{5}{*}{ (5) : 母岩の岩種* } & $\begin{array}{l}\text { ・地質年代・岩種－破砕帯幅（及びその頻度分布） } \\
\text { ・岩種（軟岩・硬岩）－破䂗帯幅（及びその頻度分布） }\end{array}$ \\
\hline & $\begin{array}{l}\text { ・地質年代・岩種一粘土状破砕幅（及びその頻度分布） } \\
\text { ・岩種（軟岩・硬岩）-破砕帯幅（及びその頻度分布） }\end{array}$ \\
\hline & $\begin{array}{l}\text { ・地質年代・岩種一ダメージゾーン幅（及びその頻度分布） } \\
\text { ・岩種（軟岩・硬岩）-破砕帯幅（及びその頻度分布） }\end{array}$ \\
\hline & $\begin{array}{l}\text { ・地質年代・岩種－透水係数（及びその頻度分布） } \\
\text { ・岩種（軟岩・硬岩）－破䂺帯幅（及びその頻度分布） }\end{array}$ \\
\hline & $\begin{array}{l}\cdot \text { ・地質年代・岩種－P波速度（及びその頻度分布） } \\
\text { ・岩種（軟岩・硬岩）－破砕帯幅（及びその頻度分布） }\end{array}$ \\
\hline \multirow{5}{*}{$\begin{array}{l}\text { (6) a : 物性 } \\
\text { (透水係数, 湧水量との関係) * }\end{array}$} & ・健岩部の透水係数一破砕帯の透水係数 \\
\hline & ・健岩部の透水係数一粘土状破砕部の透水係数 \\
\hline & ・健岩部の透水係数ーダメージゾーンの透水係数 \\
\hline & ・破砕带の透水係数ーダメージゾーンの透水係数 \\
\hline & ・湧水量－士被り \\
\hline \multirow{3}{*}{$\begin{array}{l}\text { (6) b : 物性 } \\
\text { ( } \mathrm{P} \text { 波速度との関係) * }\end{array}$} & ・健岩部のP 波速度－破砕帯のP 波速度 \\
\hline & ・健岩部のP 波速度ーダメージゾーンのP 波速度 \\
\hline & ・破砕带のP 波速度ーダメージゾーンのP 波速度 \\
\hline \multirow{3}{*}{$\begin{array}{l}\text { (6) c : 物性等 } \\
\text { (幅, 深さの関係) * }\end{array}$} & ・破砕帯幅－粘土状破砕幅 \\
\hline & 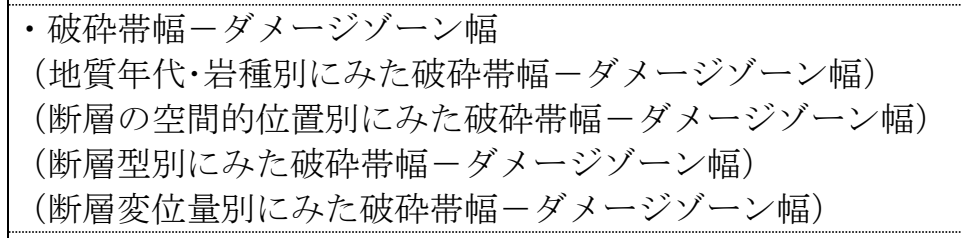 \\
\hline & ・粘土状破砕幅ーダメージゾーン幅 \\
\hline (7) : 広域応力場 & ·広域応力場 ·土被り－湧水量 \\
\hline (7) : 熱水変質作用 & - \\
\hline
\end{tabular}


Table 2-2 Correlations between the indicators and fault attributes and notable features (Kiho et al., 2009).

\begin{tabular}{|c|c|c|c|}
\hline $\begin{array}{l}\text { 着眼した } \\
\text { 要肉 }\end{array}$ & 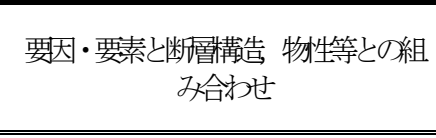 & $\begin{array}{l}\text { 相関生 } \\
の \\
\text { 有 } \\
\text { 無 }(x) \\
\end{array}$ & 特 徵 \\
\hline \multirow{5}{*}{$\begin{array}{l}\text { (1: 楣 } \\
\text { 系全本 } \\
\text { からみた } \\
\text { 位置 }\end{array}$} & •断層历空間的位置一破本带幅 & 不明 & \multirow{5}{*}{ 断㞒采の中央部のデータか殆どであり，相関生の傾向を捉えられない! } \\
\hline & •断層O空間的位置一粘十打破斾幅 & 不明 & \\
\hline & $\begin{array}{l}\text { •断層の空間的位置一ダメージラーン } \\
\text { 幅 }\end{array}$ & 不明 & \\
\hline & •断㞒の空間的置一透水綵数 & 不明 & \\
\hline & •栯層の空間的立置一P波速度 & 不明 & \\
\hline \multirow{3}{*}{$\begin{array}{l}\text { (2): 断層 } \\
\text { 型 }\end{array}$} & •断層型一破乐帯輻 & $\times$ & 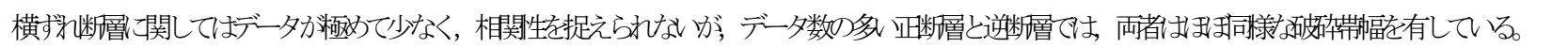 \\
\hline & •瞇㞒型一粘十状破辐 & 不明 & 正䉼畐のデータか洺じであり，相関生の僋向を捉えられない。 \\
\hline & ・断瘖型ーダメージラ゙ー幅 & $\circ$ & 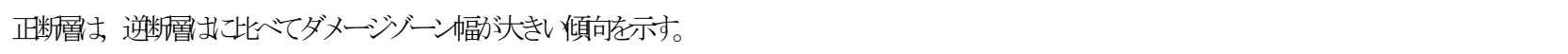 \\
\hline \multirow{2}{*}{$\begin{array}{l}\text { (3):断層 } \\
\text { 系の } \\
\text { 発達段皆 }\end{array}$} & 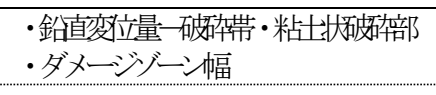 & $\circ$ & 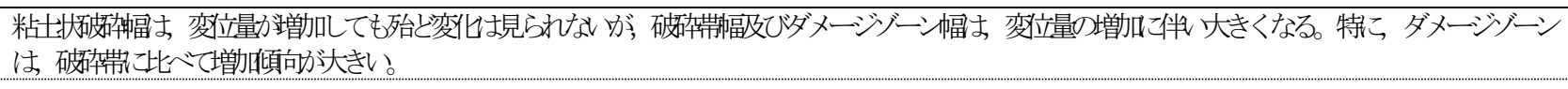 \\
\hline & 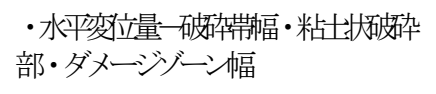 & $\circ$ & 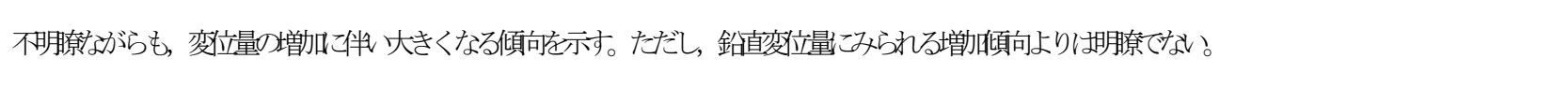 \\
\hline \multirow{3}{*}{ (4): 深さ } & 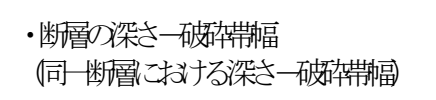 & $\begin{array}{l}\circ \\
(x)\end{array}$ & 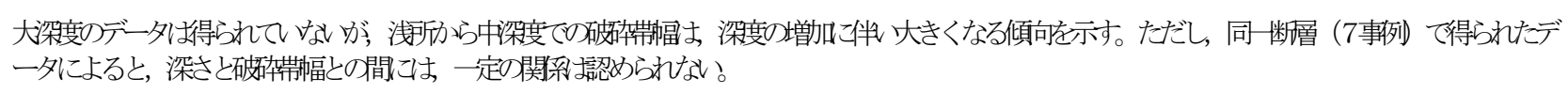 \\
\hline & •断㾇の深さ一粘十状破种畐 & $\circ$ & 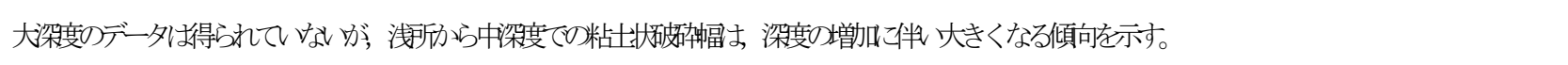 \\
\hline & 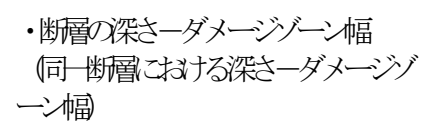 & $\begin{array}{l}\circ \\
(0)\end{array}$ & 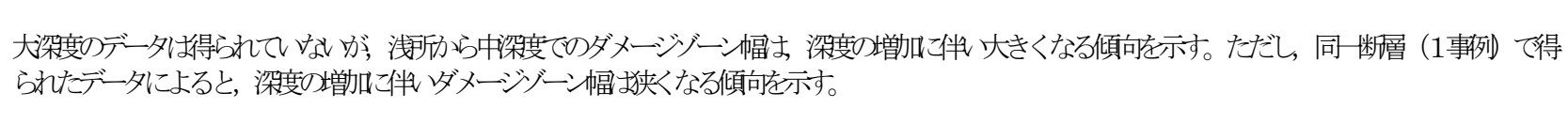 \\
\hline
\end{tabular}


(Continued)

\begin{tabular}{|c|c|c|c|}
\hline 着眼した要因 & 要因・要素と断層構造, 物性等との組み合わせ & $\begin{array}{l}\text { 相関性の } \\
\text { 有 }(\bigcirc) \text { 無 }(\times) \\
\end{array}$ & 特 徵 \\
\hline \multirow{10}{*}{ (5) : 母岩の岩種 } & 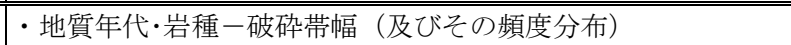 & $\times$ & 破砕帯幅は，地質年代・岩種に係わらず同様な幅を有する。 \\
\hline & ・岩種（軟岩・硬岩）一破砕帯幅（及びその頻度分布） & O & 全体にバラツキはあるものの，破砕帯幅は，硬岩＞軟岩の傾向を示す。 \\
\hline & ・地質年代·岩種一粘土状破砕幅（及びその頻度分布） & $\bigcirc$ & $\begin{array}{l}\text { 粘土状破砕幅は，堆積岩では中生代＞新第三紀，火山岩類・花骨岩類では中生代＞新 } \\
\text { 第三紀の傾向がみられる。 }\end{array}$ \\
\hline & ・岩種（軟岩·硬岩）－粘土状破砕幅（及びその頻度分布） & $\bigcirc$ & 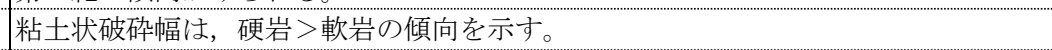 \\
\hline & ・地質年代·岩種－ダメージゾーン幅（及びその頻度分布） & $\bigcirc$ & $\begin{array}{l}\text { 全体にバラツキはあるものの, ダメージゾーン幅は, 中生代火山岩類·花骨岩類 > 中 } \\
\text { 古生層堆積岩類の傾向を示す。 }\end{array}$ \\
\hline & •岩種（軟岩·硬岩）ーダメージゾーン幅（及びその頻度分布） & 不明 & 硬岩のデータが殆どであり, 相関性の傾向を捉えられない。 \\
\hline & ・地質年代·岩種一透水係数（及びその頻度分布） & $\times$ & $\begin{array}{l}\text { 断層構成物は, その種類により透水係数は異なっており，地質年代・岩種からみた } \\
\text { 相関性は認められな。 }\end{array}$ \\
\hline & ・岩種（軟岩·硬岩）一透水係数（及びその頻度分布） & 不明 & 硬岩のデータが殆どであり，相関性の傾向を捉えられない。 \\
\hline & ・地質年代·岩種－P波速度（及びその頻度分布） & $\times$ & $\begin{array}{l}\text { データ数の極めて少ない粘土状破䂗部を除くと, 地質年代・岩種ではほぼ同様な } \mathrm{P} \\
\text { 波速度を示す。 }\end{array}$ \\
\hline & •岩種（軟岩·硬岩）－P波速度（及びその頻度分布） & $\bigcirc$ & $\begin{array}{l}\text { データ数の極めて少ない粘土状破砕部を除くと, 破砕帯・ダメージソーンのP 波速度 } \\
\text { は, 硬岩＞軟岩の傾向を示す。 }\end{array}$ \\
\hline \multirow{5}{*}{$\begin{array}{l}\text { (6) } \mathbf{a}: \text { 物性 } \\
\text { (透水係数, 湧水との } \\
\text { 関係) }\end{array}$} & ・健岩部の透水係数－破砕帯の透水係数 & O & 破砕帯の透水性は，健岩部に比して 1〜2オーダ程度高い。 \\
\hline & •健岩部の透水係数一粘土状破砕部の透水係数 & $\bigcirc$ & 粘土状破砕部の透水性は，健岩部に比して1〜3オーダ程度低い。 \\
\hline & ・健岩部の透水係数ーダメージゾーンの透水係数 & 0 & ダメージゾーンの透水性は，健岩部に比して 1〜3 オーダ程度高い。 \\
\hline & ・破砕帯の透水係数ーダメージゾーンの透水係数 & $x$ & 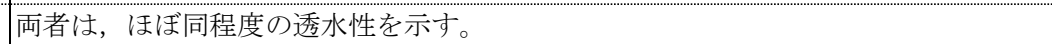 \\
\hline & ・湧水量－土被り & 0 & 湧水量は, 土被りの増加に伴って大きくなる傾向を示す。 \\
\hline \multirow{3}{*}{$\begin{array}{l}\text { (6) } \mathrm{b} \text { : 物性 } \\
\text { ( } \mathrm{P} \text { 波速度との関係) }\end{array}$} & ・健岩部のP波速度一破砕帯のP 波速度 & 0 & 破砕帯のP 波速度は，健岩部に比して最大で $1 / 5$ 程度低い。 \\
\hline & ・健岩部のP 波速度ーダメージゾーンのP波速度 & $\bigcirc$ & ダメージゾーンの P 波速度，健岩部に比して最大で $1 / 2$ 程度低い。 \\
\hline & ・破砕帯のP波速度ーダメージゾーンのP波速度 & $x$ & 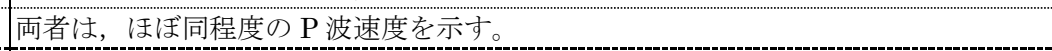 \\
\hline \multirow{7}{*}{$\begin{array}{l}\text { (6) c : 物性等 } \\
\text { (幅, 深さとの関係) }\end{array}$} & ・破砕帯幅－粘土状破研幅 & $x$ & 粘土状破砕幅は，破砕帯幅の大きさに関係なく，ほほ数 mm〜10cm 未満である。 \\
\hline & ・破砕帯幅ーダメージゾーン幅 & $\bigcirc$ & $\begin{array}{l}\text { ダメージゾーン幅は, 破砕帯幅が } 10 \mathrm{~cm} \text { 数 } \mathrm{m} \text { では } 10 \mathrm{~cm} \text { 未満であるが, 破砕帯幅 } \\
\text { が数 } \mathrm{m} \text { 数 } 10 \mathrm{~m} \text { と大きくなるとダメージゾーン幅も } 70 \text { 大 } 100 \mathrm{~m} \text { 程度と大きくなる。 }\end{array}$ \\
\hline & ・地質年代·岩種別にみた破砕帯幅ーダメージゾーン幅 & $\times$ & 破砕帯幅とダメージゾーン幅との関係は，地質年代·岩種に依存していない。 \\
\hline & ・断層の空間的位置別にみた破砕帯幅ーダメージゾーン幅 & 不明 & 断層系の中央部のデータが殆どであり，相関性の傾向を捉えられない。 \\
\hline & ・断層型別にみた破砕帯幅ーダメージゾーン幅 & 不明 & データの殆どが断層型を特定できないものが多く，相関性の傾向を捉えられない。 \\
\hline & ・断層変位量別にみた破砕帯幅ーダメージゾーン幅 & 不明 & データの殆どが変位量を特定できないものが多く, 相関性の傾向を捉えられない。 \\
\hline & ・粘土状破䂶幅ーダメージゾーン幅 & O & ダメージゾーン幅は，粘土状破砕幅の増加に伴って大きくなる傾向を示す。 \\
\hline (7) : 広域応力場 & ·広域応力場 $\cdot$ 土被り－湧水量 & O & $\begin{array}{l}\text { 湧水量は, 伸びの歪方向と断層走向とが一致している場合に大きくなる傾向が認め } \\
\text { られる。(土被りの増加に伴っても湧水量は増加傾向を示し, 湧水量の増加に広域岕 } \\
\text { 力場の影響がどの程度依存しているか評価すると難) }\end{array}$ \\
\hline
\end{tabular}




\subsubsection{Fault Classification}

木方他(2009)はさらに、前節の着眼点における地質特性と断層の水理特性の関連性について 整理している（Table 2-3 9）。それらの結果に基づいて木方他(2009)は断層の水理特性を念頭に 置いた地質特性に基づく断層のタイプ分類法の提案を行っている（Table 2-10、Figure 2-1 およ び Figure 2-2）。彼らは以下のようなタイプ分類判定作業の流れを例示している。

(1)母岩の岩種・年代による分類

母岩の岩種が軟質岩であるか硬質岩であるか。

（例）硬質岩＜wide>断層ガウジ，ダメージゾーンが発達する

軟質岩＜wide>断層ガウジやダメージゾーンの発達度が低い。

(2)断層の発達段階による分類

累積変位量が大（100m 程度以上），中（100 $1 \mathrm{~m}$ 程度），小（1m 程度未満）。

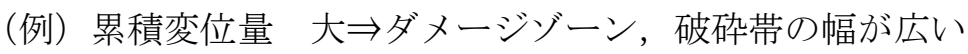

＼cjkstart断層ガウジの連続性が高い

(3)断層型および断層系全体における位置による分類

対象とする断層が，正断層，逆断層，横ずれ断層のいずれか。断層系全体のなかで，中 心部，端部，分岐・会合部のどこに位置するか。

(例) 断層の主要トレースの中心部

$\Rightarrow$ 破砕帯, ダメージゾーン, ガウジが発達し, 連続性も高い（硬質 岩, 累積変位量が大)

横ずれ断層の分岐・会合部

）断層ガウジが不連続であり，ダメージゾーンの連結により断層を横断する方向の高 透水ゾーンが形成される可能性。

(4)破砕帯の幅, 断層ガウジの連続性による分類

（例）断層ガウジの発達，連続性が高い（硬質岩）

$\Rightarrow$ 低透水性の断層ガウジが遮水ゾーンを形成する。

(5)ダメージゾーンの幅，連続性による分類

（例）ダメージゾーンの幅が広いの断層周辺に高透水性ゾーンが広く分布する。 


\subsubsection{Summary}

木方他(2009)は断層の水理特性を変化させる地質学的要因を組み合わせることで，断層の地 質特性から断層の周辺の高透水性となる範囲の大小と異方性の強弱を間接的に推定できる可能 性があることを示した。以下、木方他(2009)の結論を要約した。

1. 断層ガウジが母岩の種類によらず低い透水性を示す。

2. ガウジを除く断層破砕帯やダメージゾーンは概ね高い透水性を示す。

3. 断層破砕帯やダメージゾーンの幅の大きさは, 母岩の物性的な強度や断層の累積変位 量との相関性が比較的高い。

4. 断層核に対するダメージゾーンの幅は 10 倍〜100 倍と考えられる。

5. ダメージゾーンの連続性は比較的良い傾向が見られる。

6. 変位量が大きくなるほど断層核の連続性が良くなる傾向が認められる。

7. ガウジが不連続的である場合や, 分岐・雁行部・端部ではガウジが分布しない場合が 多い。

8. 断層を地質特性からタイプ分類することにより, 間接的に水理特性を推定できる可能 性がある。

9. 位置と水理特性との関連性をデータに基づいて示すことは出来なかった。

10. 断層ガウジの有無や, ダメージゾーンの空間的拡がり等は, ほぼ同一な条件下でもデ ータのばらつきが大きい

11．地質特性からの水理特性の推定においては，ある程度の不確実性が伴う

12. 土被り及び応力場や熱水変質作用との関係を合わせて検討することで水理特性の推 定の精度が高められる可能性がある。 
Table 2-3 Relationship between geologic and hydrologic characteristics (relative to position within a fault system), Kiho et al. (2009).

\section{断層系全体からみた位置との関係}

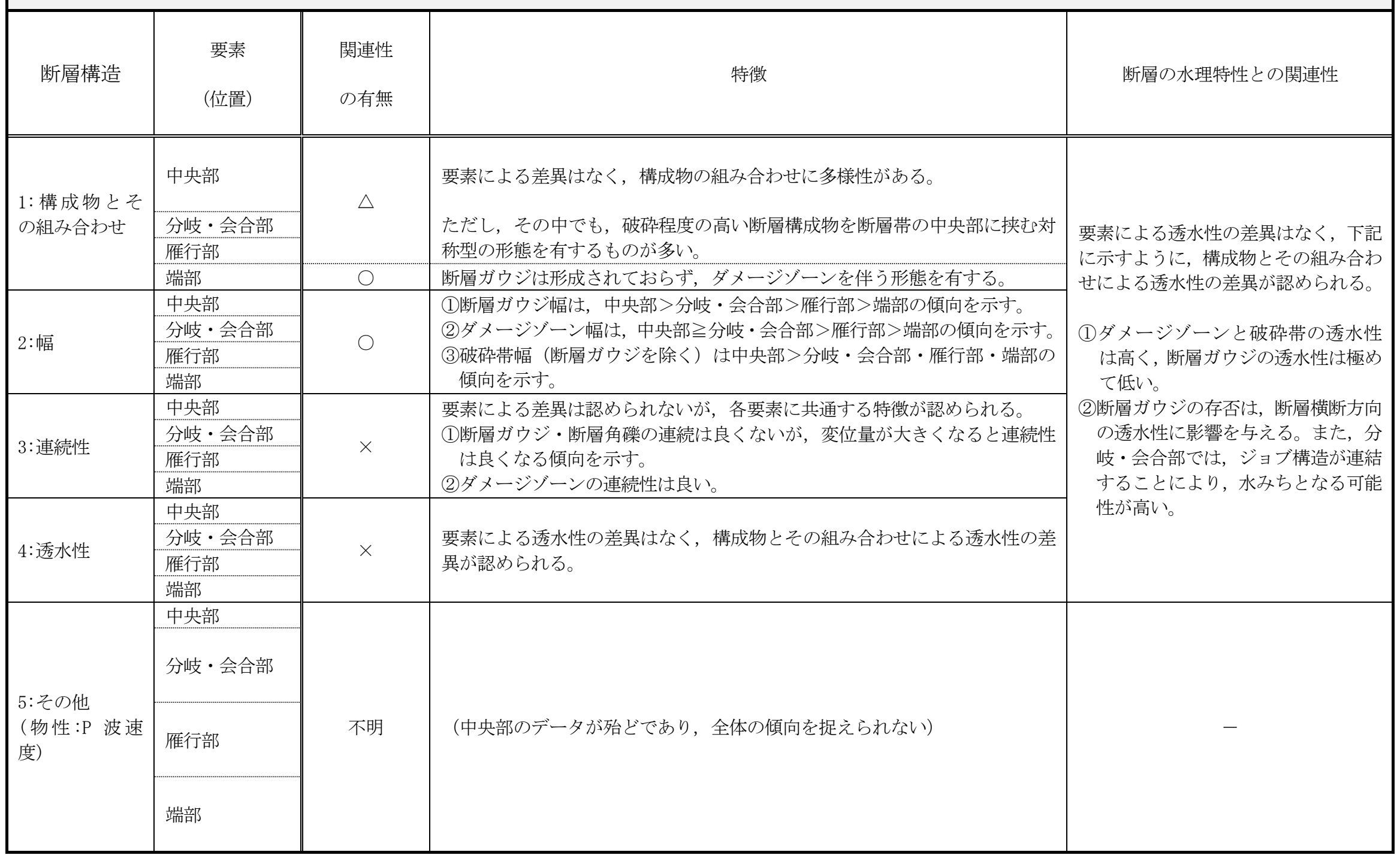


Table 2-4 Relationship between geologic and hydrologic characteristics (relative to fault type), Kiho et al. (2009).

\begin{tabular}{|c|c|c|c|c|}
\hline 断層型との関係 & & & & \\
\hline 断層構造 & $\begin{array}{c}\text { 要素 } \\
\text { (断層型) }\end{array}$ & $\begin{array}{l}\text { 関連性 } \\
\text { の有無 }\end{array}$ & 特徵 & 断層の水理特性との関連性 \\
\hline \multirow{3}{*}{$\begin{array}{l}1 \text { : 構成物と } \\
\text { その組み合わせ }\end{array}$} & 正断層 & $x$ & $\begin{array}{l}\text { 断層ガウジが破砕帯の上盤側及び下盤側の母岩との境界部に形成されてお } \\
\text { り, 多椂性を有する。 }\end{array}$ & \multirow{12}{*}{$\begin{array}{l}\text { 要素による透水性の差異はなく, 構成 } \\
\text { 物とその組み合わせて透水性が } \\
\text { 異なる。 } \\
\text { (1)断層ガウジは透水性が極めて小さ } \\
\text { く, その存在の有無が断層横断方向 } \\
\text { の透水性を支配する。 } \\
\text { (2)ダメージゾーンでは断層面に平行す } \\
\text { る水みち } \\
\text { (縌・横方向) が多数存在し, 地下の } \\
\text { 広域流動を可能にする。 }\end{array}$} \\
\hline & 逆断層 & & 断層ガウジを伴うものと伴わないものとが存在するとともに, 破砕程度の高 & \\
\hline & 横ずれ断層 & 人 & 在する非対称型を示すものとが混在しており，多様性を有する。 & \\
\hline \multirow{3}{*}{ 2:幅 } & 正断層 & \multirow{3}{*}{$\triangle$} & \multirow{3}{*}{$\begin{array}{l}\text { 全体的にみれば, による構成物の幅に差異は認められない。ただし, ダメー } \\
\text { ジゾーンにに限ってみると, 正断層＞逆断層の傾向が認められる。 }\end{array}$} & \\
\hline & 逆断層 & & & \\
\hline & 横ずれ断層 & & & \\
\hline \multirow{3}{*}{ 3:連続性 } & 正断層 & \multirow{3}{*}{$x$} & \multirow{3}{*}{$\begin{array}{l}\text { 要素による構成物の連続性に差異はないが，下記の傾向が認められる。 } \\
\text { (1)断層ガウジ・断層角砅は膨張する。断層ガウジの連続性は悪い。 } \\
\text { (2)ターメージン゙ーンは, 比較的連続性は良い。 }\end{array}$} & \\
\hline & 逆断層 & & & \\
\hline & 横ずれ断層 & & & \\
\hline \multirow{3}{*}{ 4:透水性 } & 正断層 & \multirow{3}{*}{$x$} & \multirow{3}{*}{$\begin{array}{l}\text { 要素による透水性の差異はなく, 構成物とその組み合わせによって透水性が } \\
\text { 異なる。 }\end{array}$} & \\
\hline & 逆断層 & & & \\
\hline & 横ずれ断層 & & & \\
\hline
\end{tabular}


Table 2-5 Relationship between geologic and hydrologic characteristics (relative to fault development stage), Kiho et al. (2009).

\section{断層系の発達段階との関係}

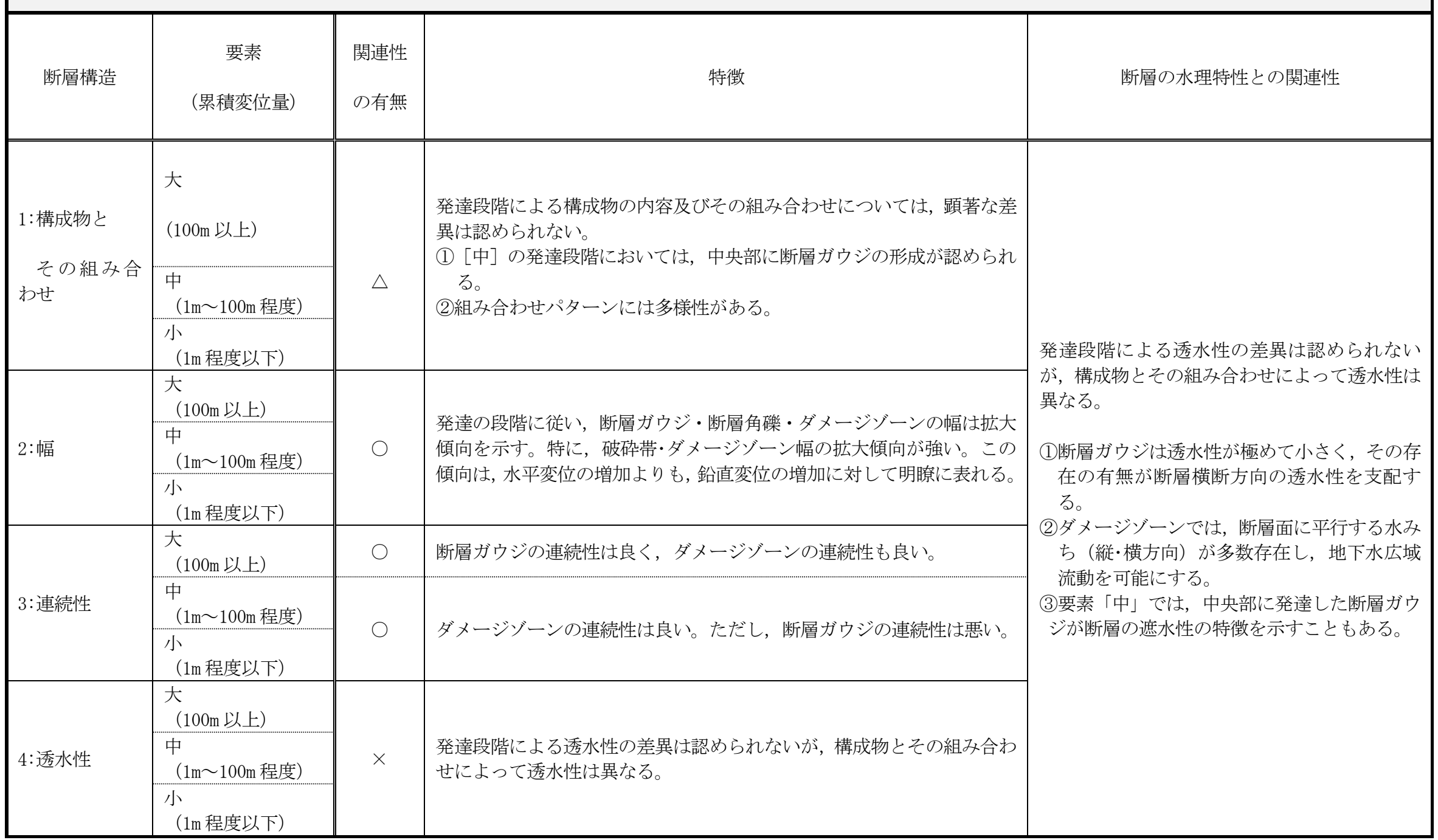


Table 2-6 Relationship between geologic and hydrologic characteristics (relative to depth), Kiho et al. (2009).

\begin{tabular}{|c|c|c|c|c|}
\hline \multicolumn{5}{|l|}{ 深さとの関係 } \\
\hline 断層構造 & $\begin{array}{l}\text { 要素 } \\
\text { (深さ) }\end{array}$ & $\begin{array}{l}\text { 関連性 } \\
\text { の有無 }\end{array}$ & 特徵 & 断層の水理特性との関連性 \\
\hline $\begin{array}{l}1 \text { : 構成物とそ } \\
\text { の組み合わせ }\end{array}$ & $\begin{array}{l}\text { 浅所 } \\
\text { (数十 } \mathrm{m} \text { 以浅) } \\
\text { 中深度 (数百 } \mathrm{m} \text { ) } \\
\text { 大深度 } \\
\text { (数 } \mathrm{km} \text { 以深) }\end{array}$ & 不明 & $\begin{array}{l}\text { 深さ方向にみた断層構成物の組み合わせに関する文献は極めて少なく, その関連 } \\
\text { 性については不明である。 } \\
\text { ただし, 断層構造に深さ方向の差異がないことから判断すると, 深さによって構 } \\
\text { 成物の内容及びその組み合わせが変化するとは考えにくい。 }\end{array}$ & \multirow{6}{*}{ 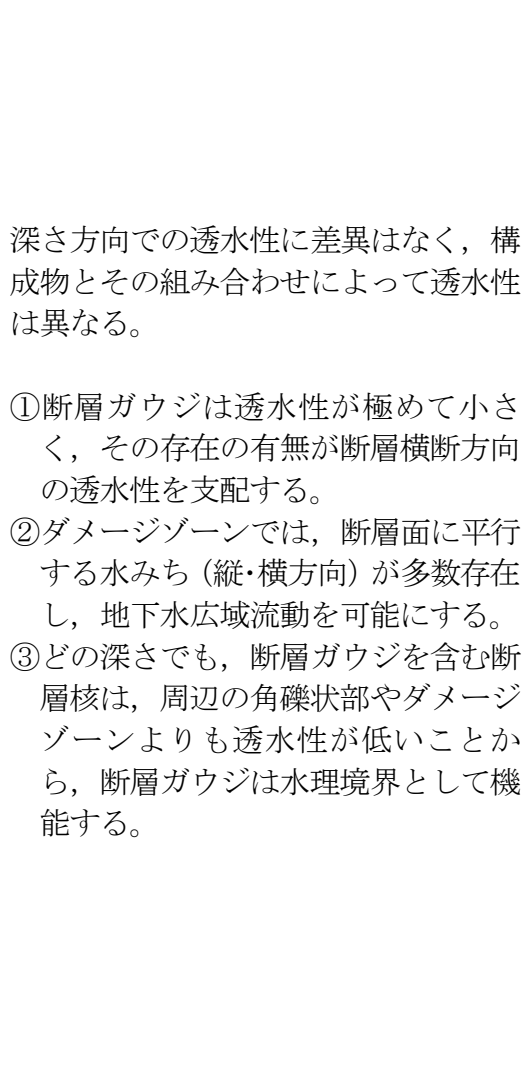 } \\
\hline \multirow[t]{2}{*}{ 2:幅 } & $\begin{array}{l}\text { 浅所 } \\
\text { (数十 } \mathrm{m} \text { 以浅) } \\
\text { 中深度 } \\
\text { (数百 } \mathrm{m} \text { ) }\end{array}$ & $\triangle$ & $\begin{array}{l}\text { 同一断層における深さと破䂗帯幅との関係をみると, 両者間には一定の関係は認 } \\
\text { められない。 } \\
\text { ただし, 同一断層における深さとダメージゾーン幅との関係が得られた事例では, } \\
\text { 深さが増すにつれで゙メージゾーン幅が狭くなる傾向がみられる。 }\end{array}$ & \\
\hline & $\begin{array}{l}\text { 大深度 } \\
\text { (数 km 以深) }\end{array}$ & 不明 & (データが得られていない。) & \\
\hline \multirow[t]{2}{*}{ 3:連続性 } & $\begin{array}{l}\text { 浅所 } \\
\text { (数十 } \mathrm{m} \text { 以浅) } \\
\text { 中深度 } \\
\text { (数百 } \mathrm{m})\end{array}$ & 不明 & $\begin{array}{l}\text { 連続性に関するデータは得られていないため不明であるが, 断層構造に深さ方向 } \\
\text { の差異がことから判断すると, 基本的には, 深さによって連続性が著しく変 } \\
\text { 化するとは考えにくい。 }\end{array}$ & \\
\hline & $\begin{array}{l}\text { 大深度 } \\
\text { (数 km 以深) }\end{array}$ & 不明 & (データが得られていない。) & \\
\hline 4 : 透水性 & $\begin{array}{l}\text { 浅所 } \\
\text { (数十 } \mathrm{m} \text { 以浅) } \\
\text { 中深度 } \\
\text { (数百 } \mathrm{m} \text { ) } \\
\text { 大深度 } \\
\text { (数 } \mathrm{km} \text { 以深) }\end{array}$ & $\times$ & $\begin{array}{l}\text { 深さ方向での透水性に差異はなく, 構成物とその組み合わせによって透水性は異 } \\
\text { なる。 }\end{array}$ & \\
\hline
\end{tabular}


Table 2-7 Relationship between geologic and hydrologic characteristics (relative to protolith rock type), Kiho et al. (2009).

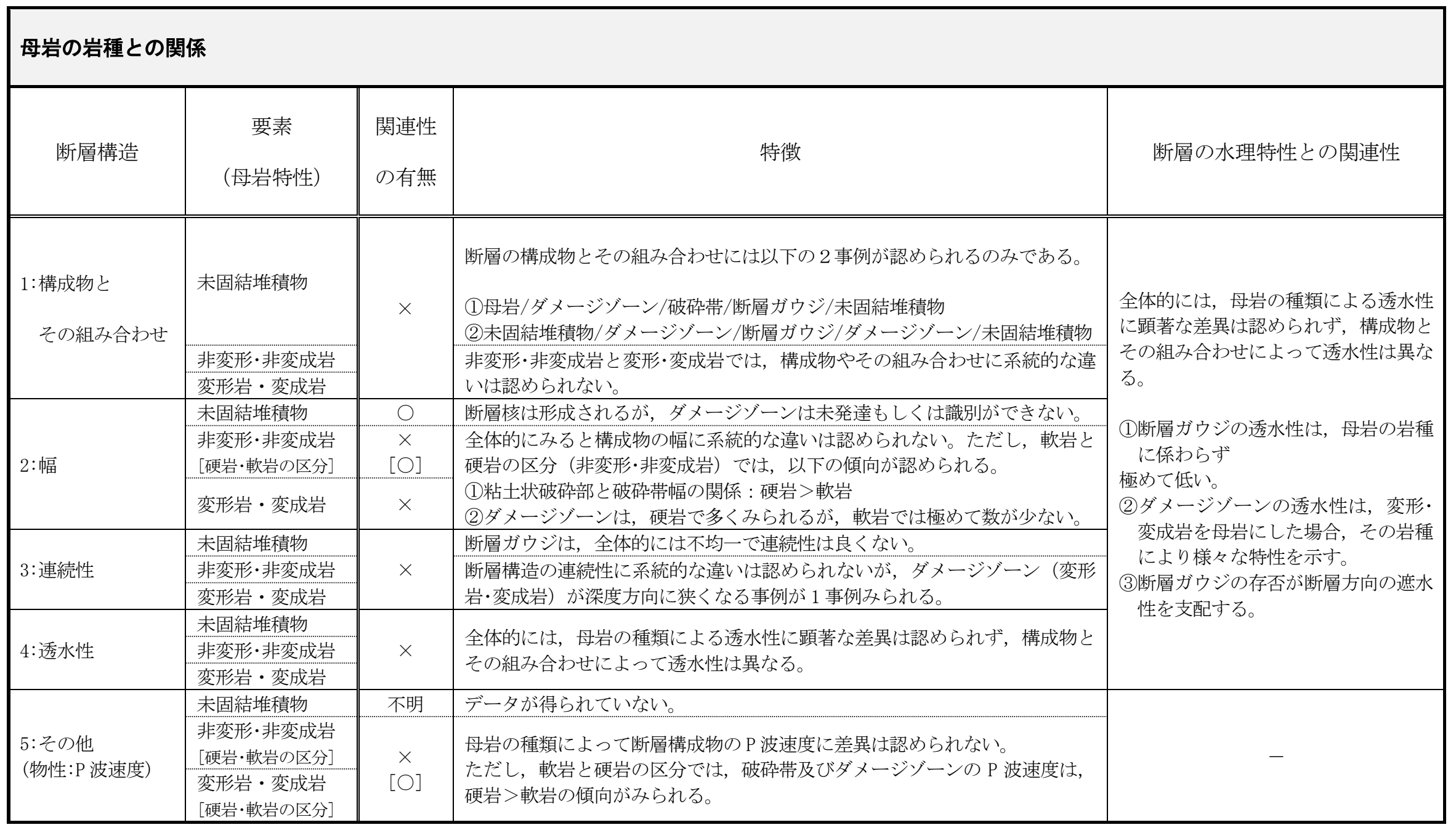


Table 2-8 Relationship between geologic and hydrologic characteristics (relative to material type), Kiho et al. (2009).

\begin{tabular}{|c|c|c|c|c|}
\hline \multicolumn{5}{|c|}{ 断層帯の構造とその物性等との関係 } \\
\hline 特徵 & 関係 & $\begin{array}{l}\text { 関連性 } \\
\text { の有無 }\end{array}$ & 特徵 & 断層の水理特性との関連性 \\
\hline \multirow{3}{*}{1 :透水性 } & $\begin{array}{l}\text { 粘土状破砕部/健 } \\
\text { 岩部 }\end{array}$ & $\bigcirc$ & 粘土状破砕部＜健岩部（1～3 オーダ程度） & \multirow{3}{*}{ 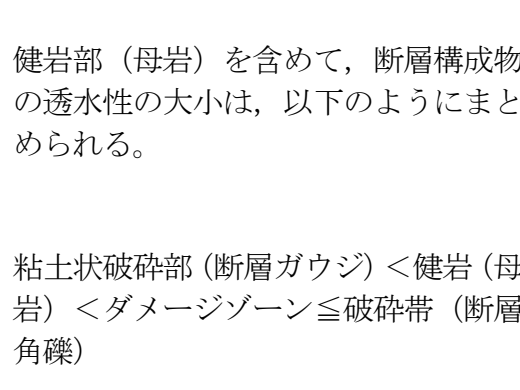 } \\
\hline & $\begin{array}{l}\text { ダメージゾーン/ } \\
\text { 健岩部 }\end{array}$ & $\bigcirc$ & 健岩部＜ダメージゾーン（1〜3オーダ程度） & \\
\hline & $\begin{array}{l}\text { ダメージゾーン/ } \\
\text { 破砕帯 }\end{array}$ & $\bigcirc$ & ダメージゾーンミ破砕带 & \\
\hline \multirow[t]{2}{*}{$\begin{array}{l}\text { 2: 力学的特性 } \\
\text { (P 波速度) }\end{array}$} & $\begin{array}{l}\text { ダメージゾーン/ } \\
\text { 健岩部 }\end{array}$ & $\bigcirc$ & 健岩部>ダメージゾーン & \multirow[t]{2}{*}{-} \\
\hline & $\begin{array}{l}\text { ダメージゾーン/ } \\
\text { 破砕帯 }\end{array}$ & $\bigcirc$ & 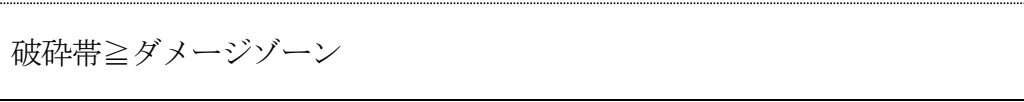 & \\
\hline \multirow{3}{*}{ 3:断層構造 } & $\begin{array}{l}\text { 破砕帯幅/粘土状 } \\
\text { 破哗幅 }\end{array}$ & $\bigcirc$ & $\begin{array}{l}\text { 粘土状破砕部は，破砕带幅に関係なく，以下のような関係を示す。 } \\
\text { 数 } \mathrm{mm}<\text { 粘土状破砕部（断層ガウジ）<10cm }\end{array}$ & - \\
\hline & $\begin{array}{l}\text { ダメージゾーン幅 } \\
\text { /破硪帯幅 }\end{array}$ & $\bigcirc$ & $\begin{array}{l}\text { 破砕幅が数 } \mathrm{m} \text { 未満 : ダメージゾーンミ破砕帯 } \\
\text { 破砕幅が数 } \mathrm{m} \text { 未満 : ダメージゾーン》破䂗帯 }\end{array}$ & - \\
\hline & $\begin{array}{l}\text { 粘土状破砕幅/ダ } \\
\text { メージゾーン幅 }\end{array}$ & $\bigcirc$ & 粘土状破砝幅の増加に伴い，ダメージゾーンの幅も大きくなる傾向を示す。 & - \\
\hline
\end{tabular}


Table 2-9 Relationship between geologic and hydrologic characteristics (relative to regional stress field and hydrothermal alteration), Kiho et al. (2009).

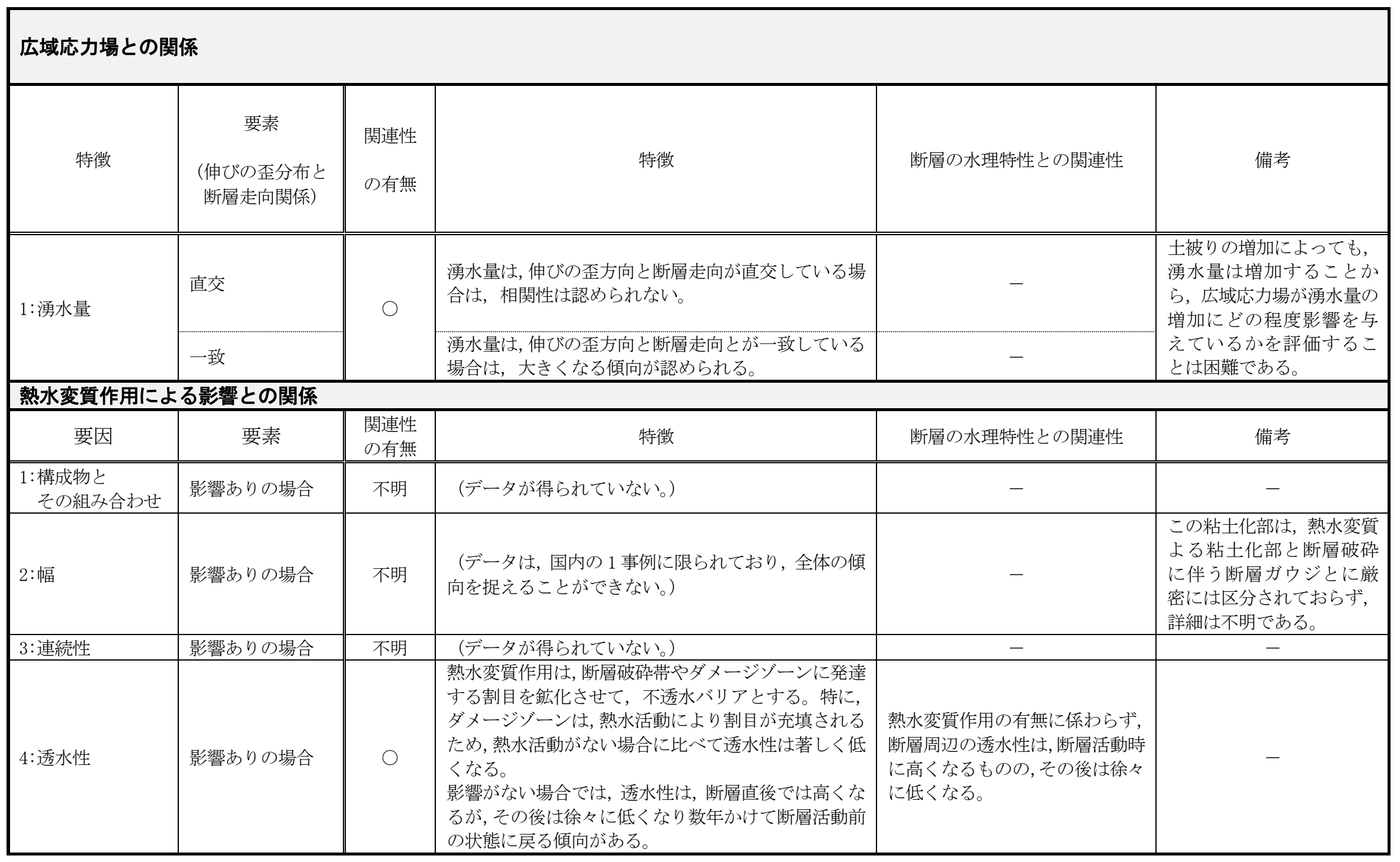


Table 2-10 Type classification of faults (Kiho et al., 2009)

\begin{tabular}{|c|c|c|c|c|c|c|}
\hline & 岩種, 地質年代 & 累積変位量 & 断層型および断層系全体における位置 & 破砕帯幅 & $\begin{array}{l}\text { ダメージゾー } \\
\text { ンを含めた } \\
\text { 幅 }\end{array}$ & 高透水性となる範囲の大小と異方性の強弱 \\
\hline タイプ1 & 硬質岩 & 大 & 正·逆断層, 横ずれ断層の主要トレース & $\begin{array}{c}\stackrel{大}{\text { (ガウジ連続) }} \\
\text { ( }\end{array}$ & 大 & $\begin{array}{l}\text { 高透水性となる範囲は広い。ガウジは連続するた } \\
\text { め, 難透水性ゾーンは連続性を示す（異方性強 } \\
\text { い)。 }\end{array}$ \\
\hline タイプ2 & 硬質岩 & 大 & 正·逆断層, 横ずれ断層の主要トレース & $\begin{array}{c}\stackrel{\text { 大 }}{\text { (ガウジ不連続) }} \\
\text { (カ) }\end{array}$ & 大 & $\begin{array}{l}\text { 高透水性となる範囲は広い。ガウジは不連続なた } \\
\text { め, 難透水性ゾーンは不連続性を示す（異方性弱 } \\
\text { (）。 }\end{array}$ \\
\hline タイプ3 & 硬質岩 & 中〜小 & $\begin{array}{l}\text { 正·逆断層, 横ずれ断層の主要トレース, } \\
\text { 屈曲部, ステップ部, 末端部 }\end{array}$ & $\begin{array}{c}\text { 小 } \\
\text { (ガウジ不連続) }\end{array}$ & 大 & $\begin{array}{l}\text { 高透水性となる範囲は広い。ガウジは不連続なた } \\
\text { め, 難透水性ゾーンは不連続性を示す（異方性弱 } \\
\text { い)。 }\end{array}$ \\
\hline タイプ4 & 硬質岩 & 中 小 & $\begin{array}{l}\text { 正·逆断層, 横ずれ断層の主要トレース, } \\
\text { 屈曲部, ステップ部, 末端部 }\end{array}$ & $\begin{array}{c}\text { 小 } \\
\text { (ガウジ不連続) }\end{array}$ & 小 & $\begin{array}{l}\text { 高透水性となる範囲は比較的狭い。ガウジは不連 } \\
\text { 続なため, 難透水性ゾーンは不連続性を示す（異方 } \\
\text { 性弱い)。 }\end{array}$ \\
\hline タイプ5 & 硬質岩 & 中〜小 & $\begin{array}{l}\text { 横ずれ断層の屈曲部, ステップ部，末端 } \\
\text { 部 }\end{array}$ & $\begin{array}{c}\text { 小 } \\
\text { (ガウジなし) }\end{array}$ & 大 & $\begin{array}{l}\text { 高透水性となる範囲は広い。ガウジは存在しないた } \\
\text { め, 難透水性ゾーン分布しない(異方性弱い)。 }\end{array}$ \\
\hline タイプ6 & 硬質岩 & 中〜小 & $\begin{array}{l}\text { 正·逆断層, 横ずれ断層の主要トレース, } \\
\text { 屈曲部, ステップ部, 末端部 }\end{array}$ & $\begin{array}{c}\text { 小 } \\
\text { (ガウジなし) }\end{array}$ & 小 & $\begin{array}{l}\text { 高透水性となる範囲は比較的狭い。ガウジは存在 } \\
\text { しないため, 難透水性ゾーンは分布しない(異方性 } \\
\text { 弱い)。 }\end{array}$ \\
\hline タイプ7 & 軟質岩 & 中〜小 & $\begin{array}{l}\text { 正·逆断層, 横ずれ断層の主要トレース, } \\
\text { 屈曲部, ステップ部, 末端部 }\end{array}$ & $\begin{array}{c}\text { 小 } \\
\text { (ガウジ不連続) }\end{array}$ & 小 & $\begin{array}{l}\text { 高透水性となる範囲は比較的狭い。ガウジは不連 } \\
\text { 続なため, 難透水性ゾーンは不連続性を示す（異方 } \\
\text { 性弱い)。 }\end{array}$ \\
\hline タイプ8 & 軟質岩 & 中〜小 & $\begin{array}{l}\text { 正·逆断層, 横ずれ断層の主要トレース, } \\
\text { 屈曲部, ステップ部, 末端部 }\end{array}$ & $\begin{array}{c}\text { 小 } \\
\text { (ガウジなし) }\end{array}$ & 小 & $\begin{array}{l}\text { 高透水性となる範囲は比較的狭い。ガウジは存在 } \\
\text { しないため, 難透水性ゾーンは分布しない(異方性 } \\
\text { 弱い)。 }\end{array}$ \\
\hline
\end{tabular}




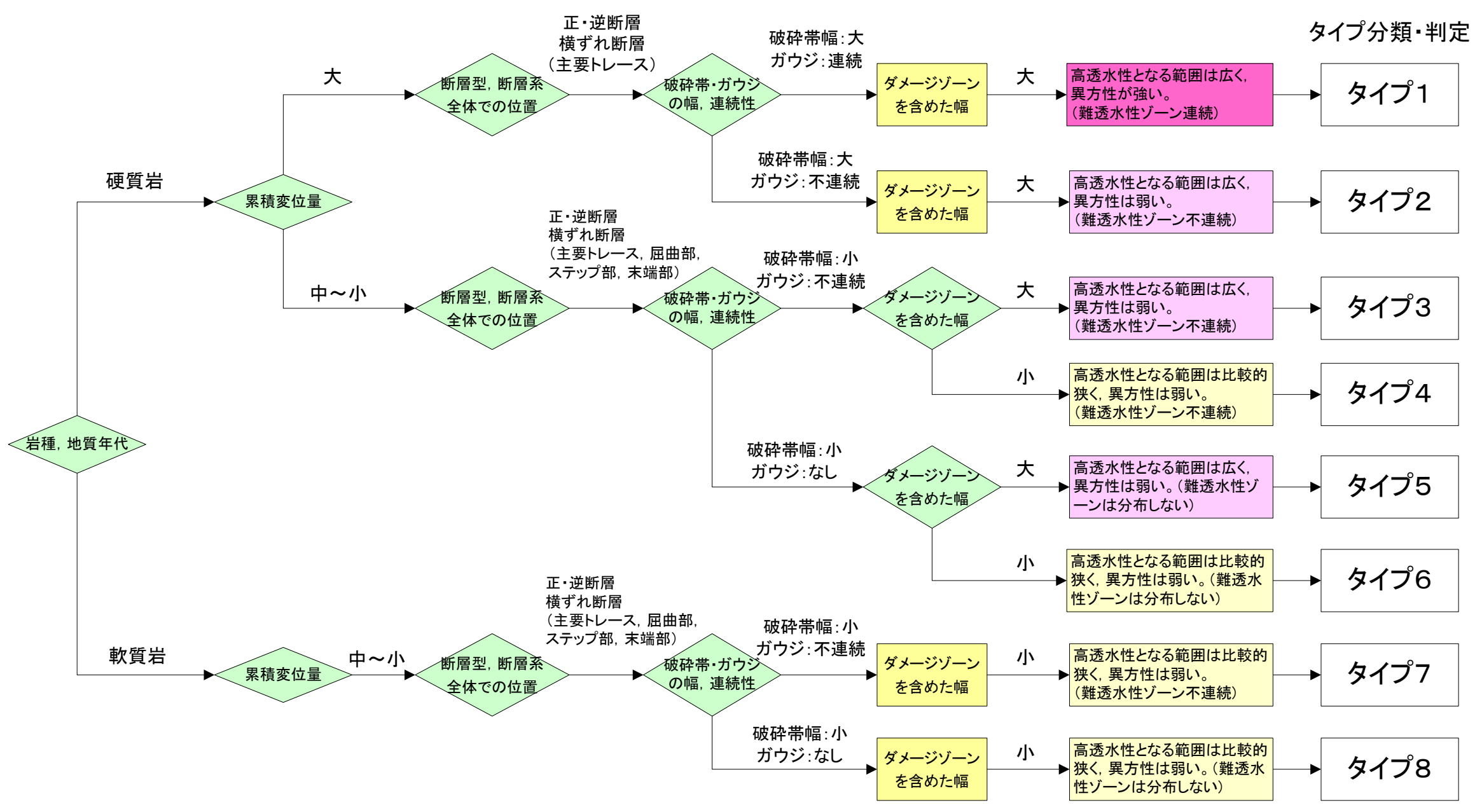

Figure 2-1 Flow diagram for type classification determination. (Kiho et al., 2009) 


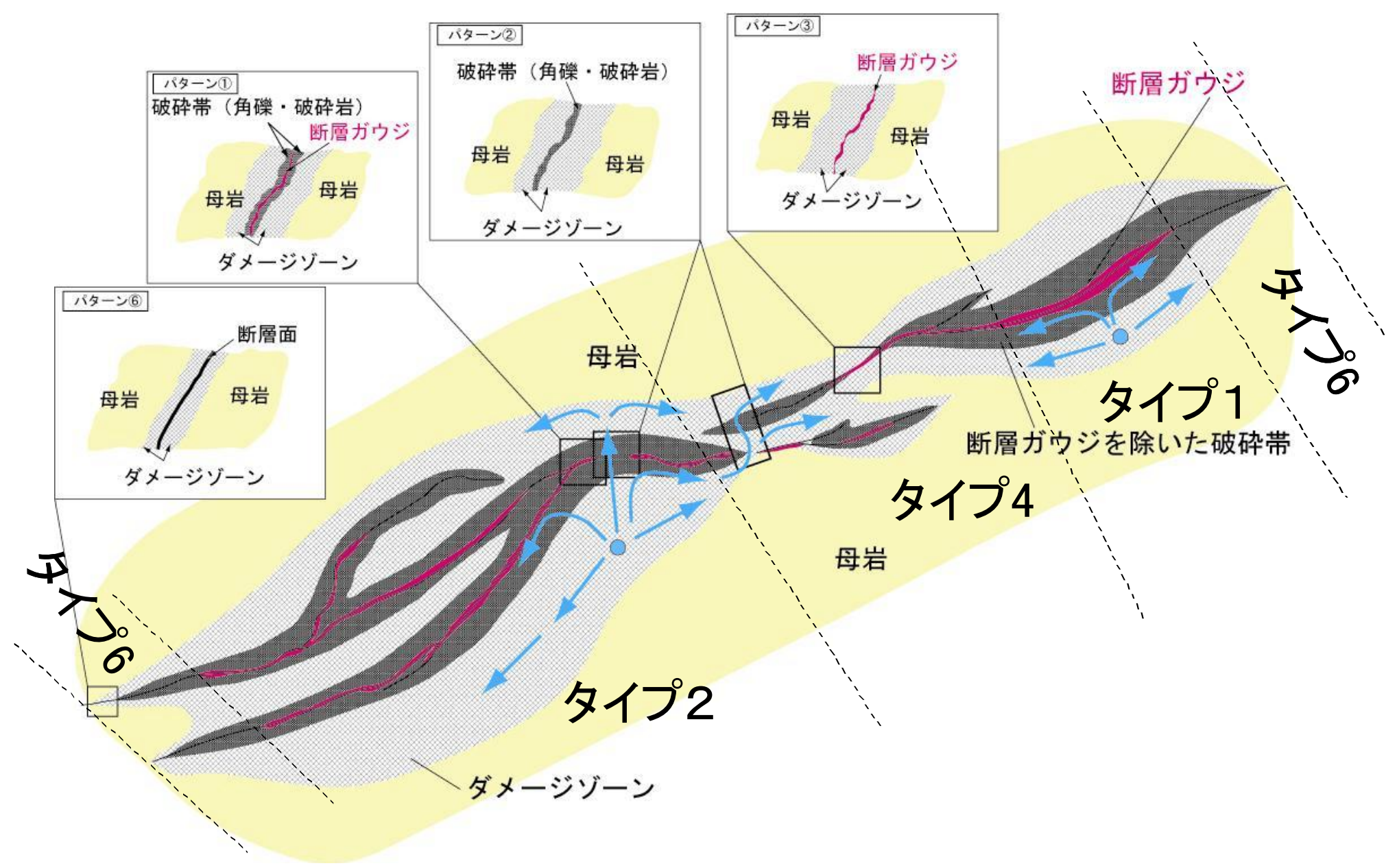

Figure 2-2 Application example of fault type classification. (Kiho et al., 2009) 


\subsection{Procedure Development for Investigation and Characterization}

本節では木方他(2009)が行った断層の影響を高所下水理特性調查の体系化を要約して記述する。木方他(2009)は概要調查、さらに 引き続き実施される精密調查時に必要となる、断層破砕帯が性能評価上重要な地下水流動特性に与える影響を考慮した調查・評価 法を体系化することを目的として、まず、概要調査やこれに類する調查に関する体系化研究の国内での事例調查を行っている。対 象機関としては, (1)日本原子力研究開発機構 (以降原子力機構)，(2)原子力環境整備促進・資金管理センター (以降原環センター),

(3)土木学会原子力土木委員会地下環境部会（以降土木学会）および(4)電力中央研究所（以降電中研）であった。

その結果、原子力機構および原環センターでは評価から調査への流れとその関連を表したデータフローダイアグラムを中心に研 究が行われているのに対し，土木学会，電中研では，これを踏まえて時系列的な調查・評価フローを中心にまとめられていること が明らかになった。木方他(2009)は，断層の影響を考慮した地下水流動特性を効率的に調査することを目的としていることを理由 に後者の時系列的な調査・評価フローを参考にまとめている。

\subsubsection{Integrated Data Flow}

木方他(2009)は評価項目，評価に用いるデータ・情報，そのデータを取得するための調查項目，調查技術の関連性のデータフロ ー（Figure 2-3）、および水理特性に関するデータフローを構築した（Figure 2-4）。

\subsubsection{Hydrologic Investigation/Characterization Flow for Fault Zones}

木方他 (2009) は地表調査段階とその後のボーリング調査段階に分割し、オーバーラップした調査・評価が行われることも想定し、 両段階において評価すべき項目として下記の 4 項目を挙げた。

(1) 透水性・貯留性

(2) ポテンシャル分布 
(3) 水質進化/地下水年代

(4) 深部フラックス

木方他(2009)はこれらの項目の調査データに基づいて, 地表調査段階のモデルを修正し, 地下水流動解析によって, 評価すべき 項目と照らし合わせることにより，断層が地下水流動へ与える影響と最終的に処分システムへ与える影響について検討する断層の 水理特性評価の考え方のフローを構築している（Figure 2-5）。さらに、断層の水理特性調査フローも前半の地表調查段階と後半 のボーリング調查段階とに分けて示している（Figure 2-6）。 


\subsection{References}

木方建造，上田圭一，宮川公雄，長谷川玩磨，田中姿郎，佐々木俊法，濱田崇臣，末永弘，金沢淳(2009)：断層の 水理特性の調査・評価手法に関する検討(その 2 )に係る調査・解析報告書, 財団法人電力中央研究所、2009. 


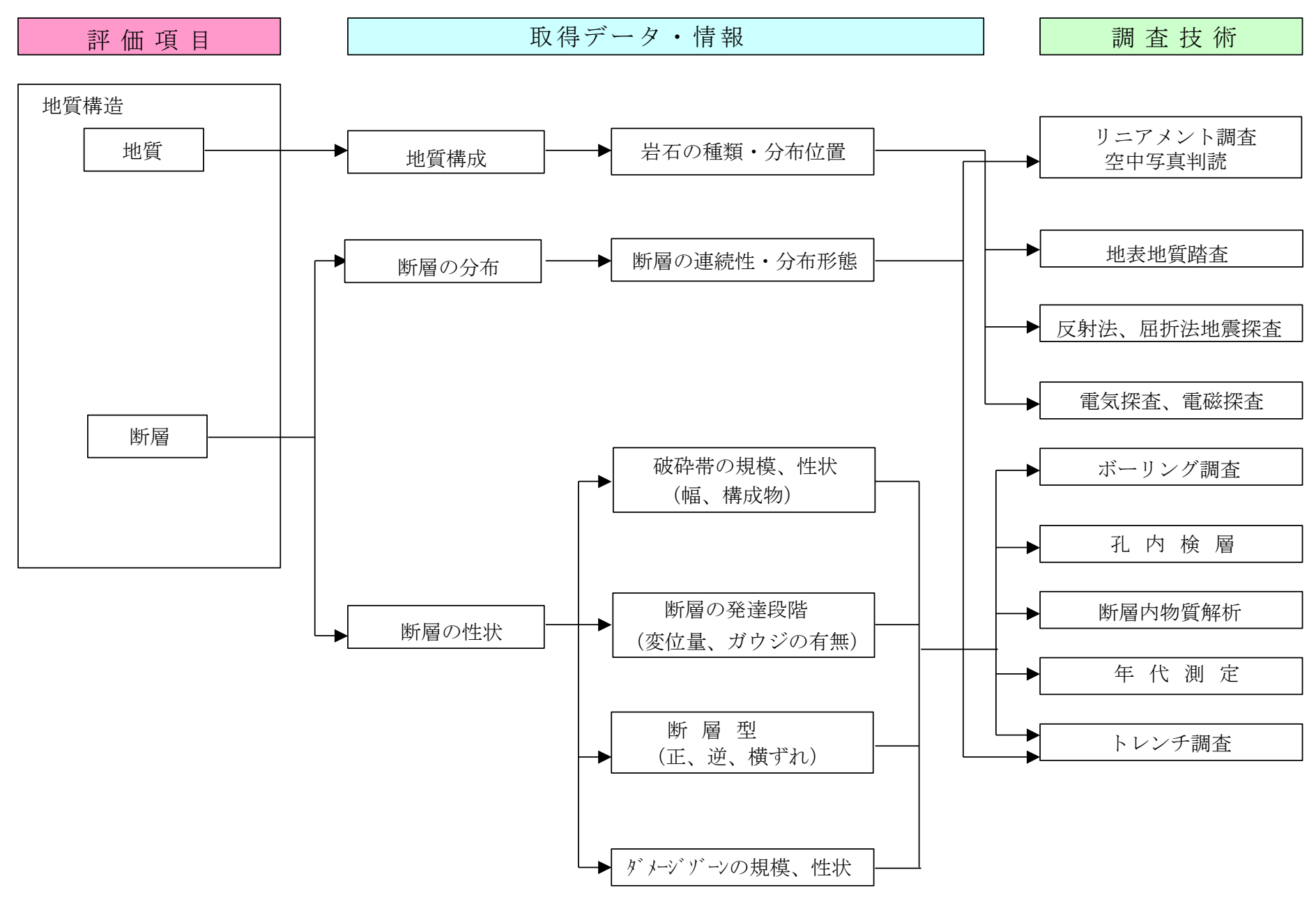

Figure 2-3 Data flow diagram for fault distribution and characteristics that affect hydrology (Kiho et al., 2009) 


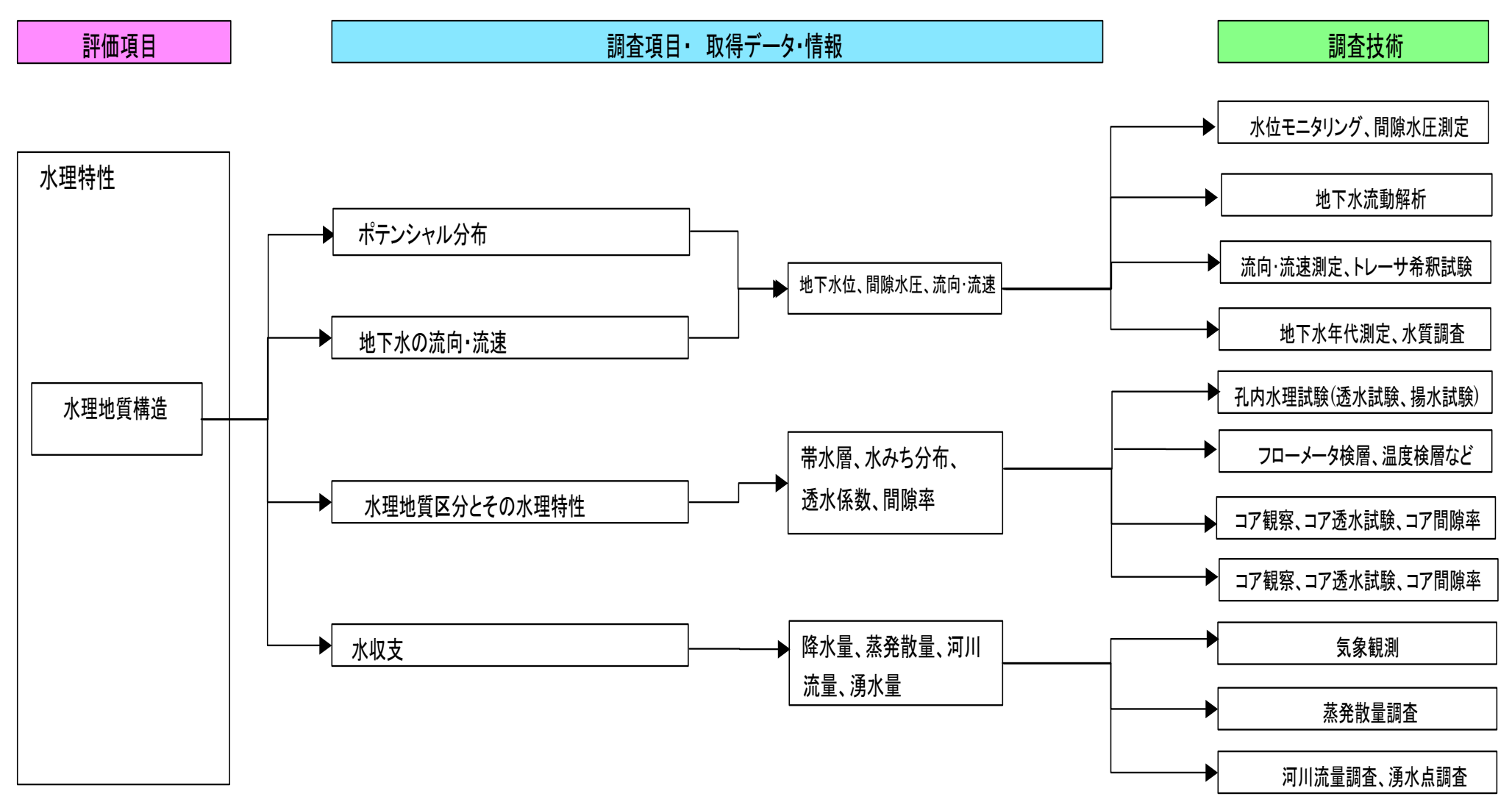

Figure 2-4 Data flow diagram for hydrologic characterization (Kiho et al., 2009) 


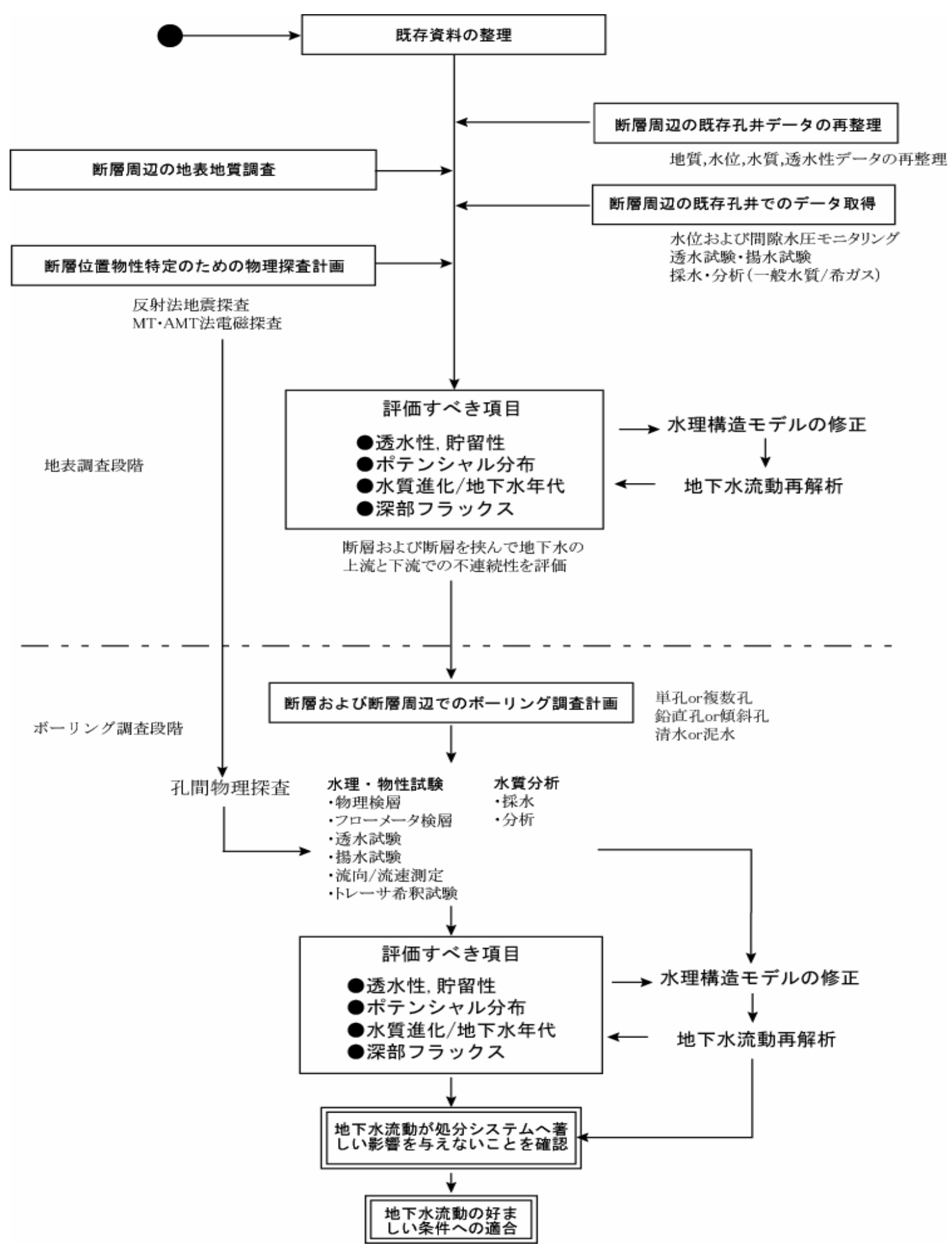

Figure 2-5 Proposed approach to hydrologic characterization of faults. (Kiho et al., 2009) 


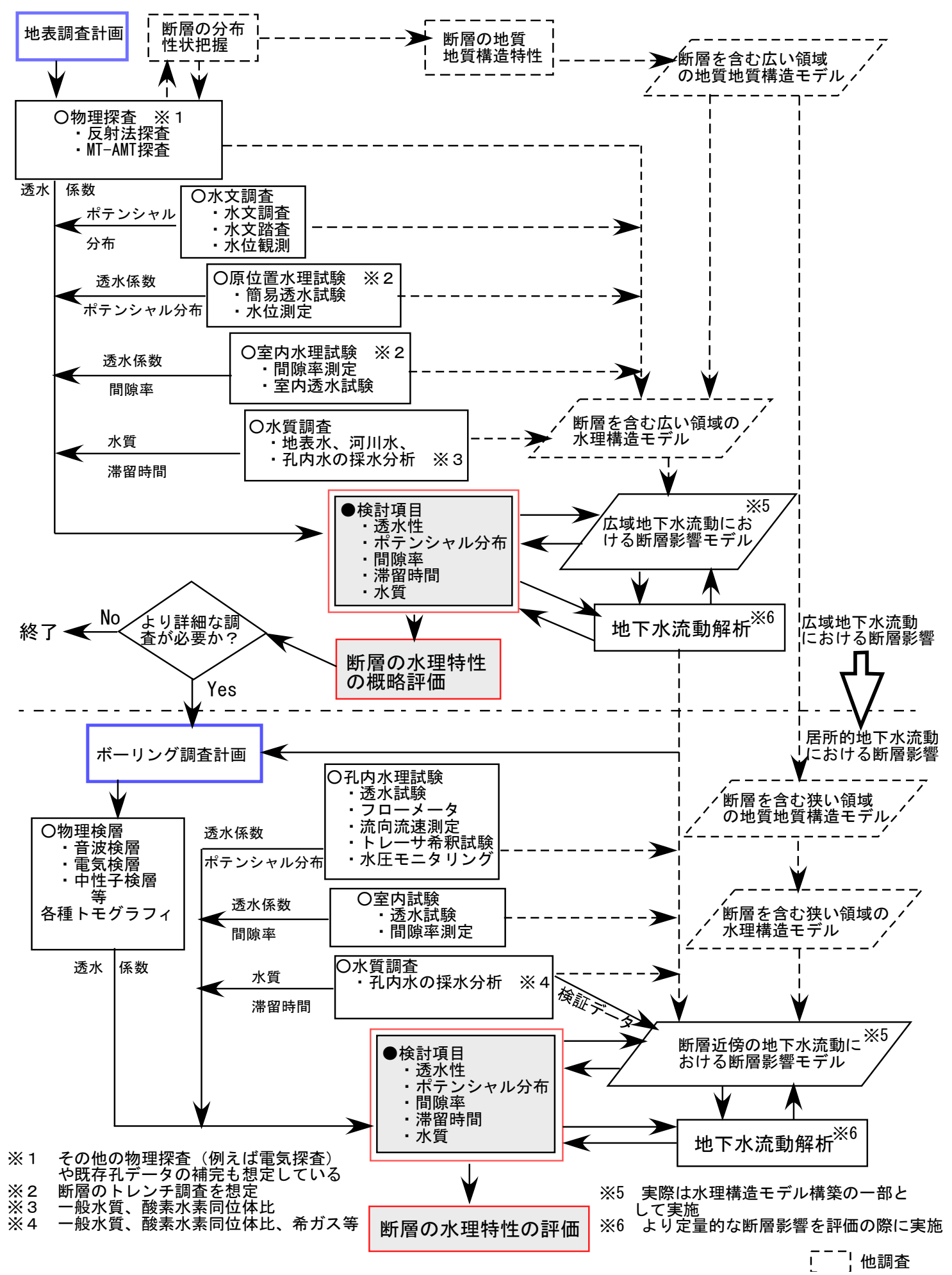

Figure 2-6 Investigation flow diagram for hydrologic characterization of faults. (Kiho et al., 2009) 


\section{Field Investigations}

\subsection{Evaluation of existing information}

In this section we summarize the results of the evaluation of existing information on the Wildcat Fault including aerial photos, published articles, project reports and other available information. The analysis of aerial photos is an excerpt from Kiho et al (2009).

\subsubsection{Aerial photo analysis}

USGS によって 1968 年に撮影された縮尺約 3 万分の 1 のモノクロ写真を使って木方他(2009) はヘイワード断層系沿いに, LBNLの敷地周辺に分布するWildcat 断層を中心とした長さ約 $25 \mathrm{~km}$ について空中写真判読をおこなっている（Figure 3-1）。Figure 3-2、Figure 3-3Figure 3-4 に彼ら の判読したリニアメントを示す。 


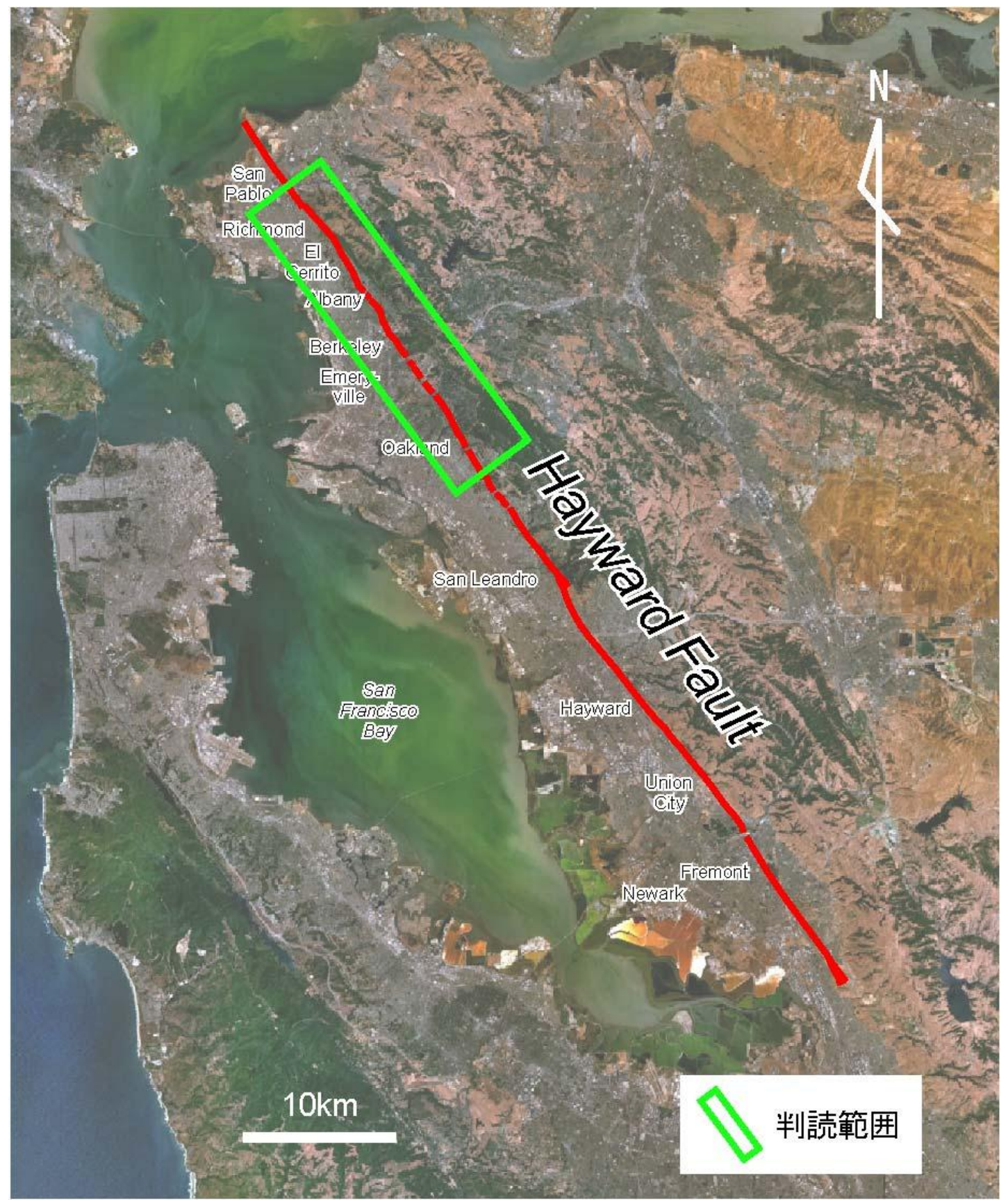

Figure 3-1 Aerial photo analysis area by Kiho et al. (2009). 


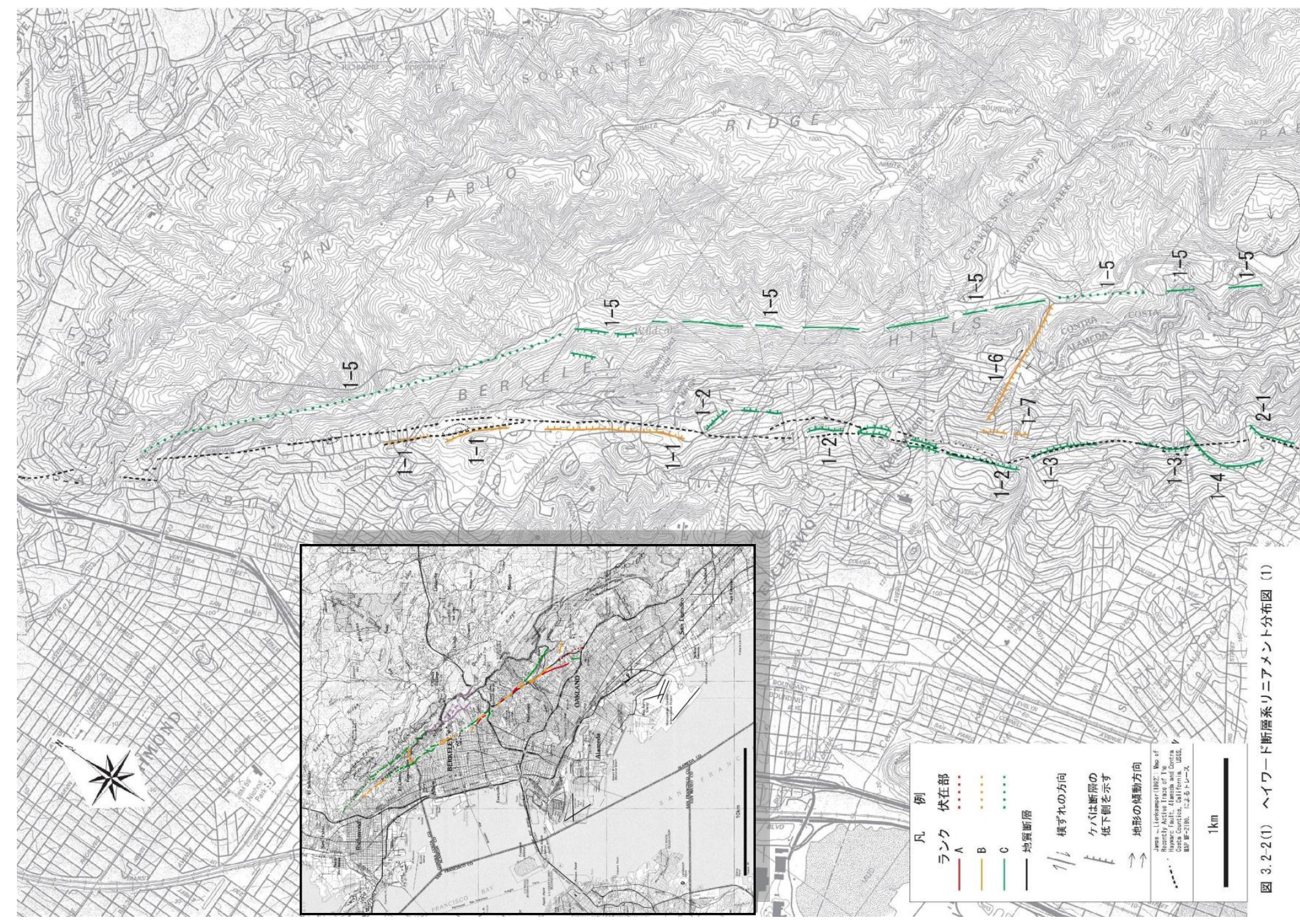

Figure 3-2 Lineaments associated with the Hayward Fault system (1). (Kiho et al., 2009) 


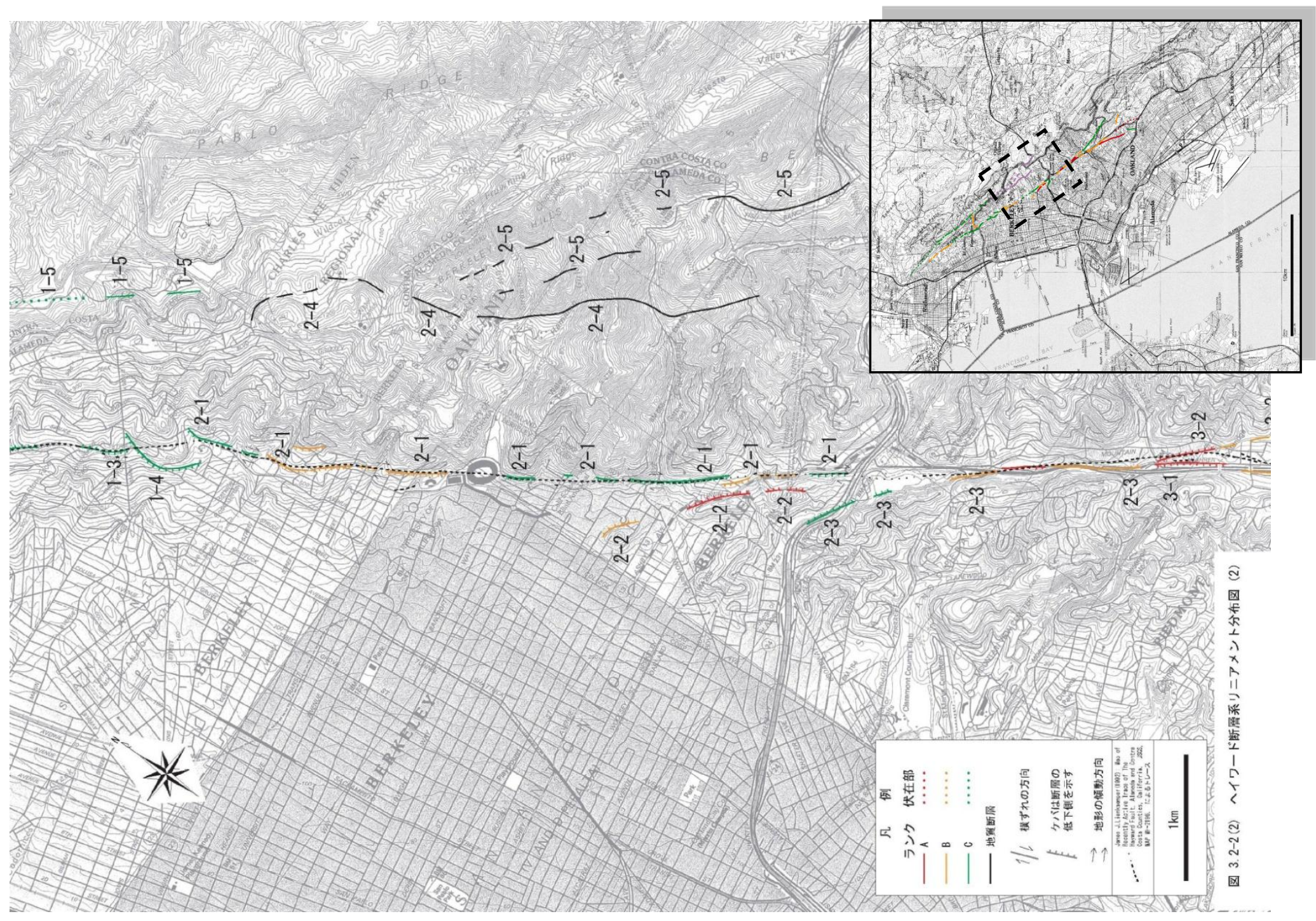

Figure 3-3 Lineaments associated with the Hayward Fault system (2). (Kiho et al., 2009) 


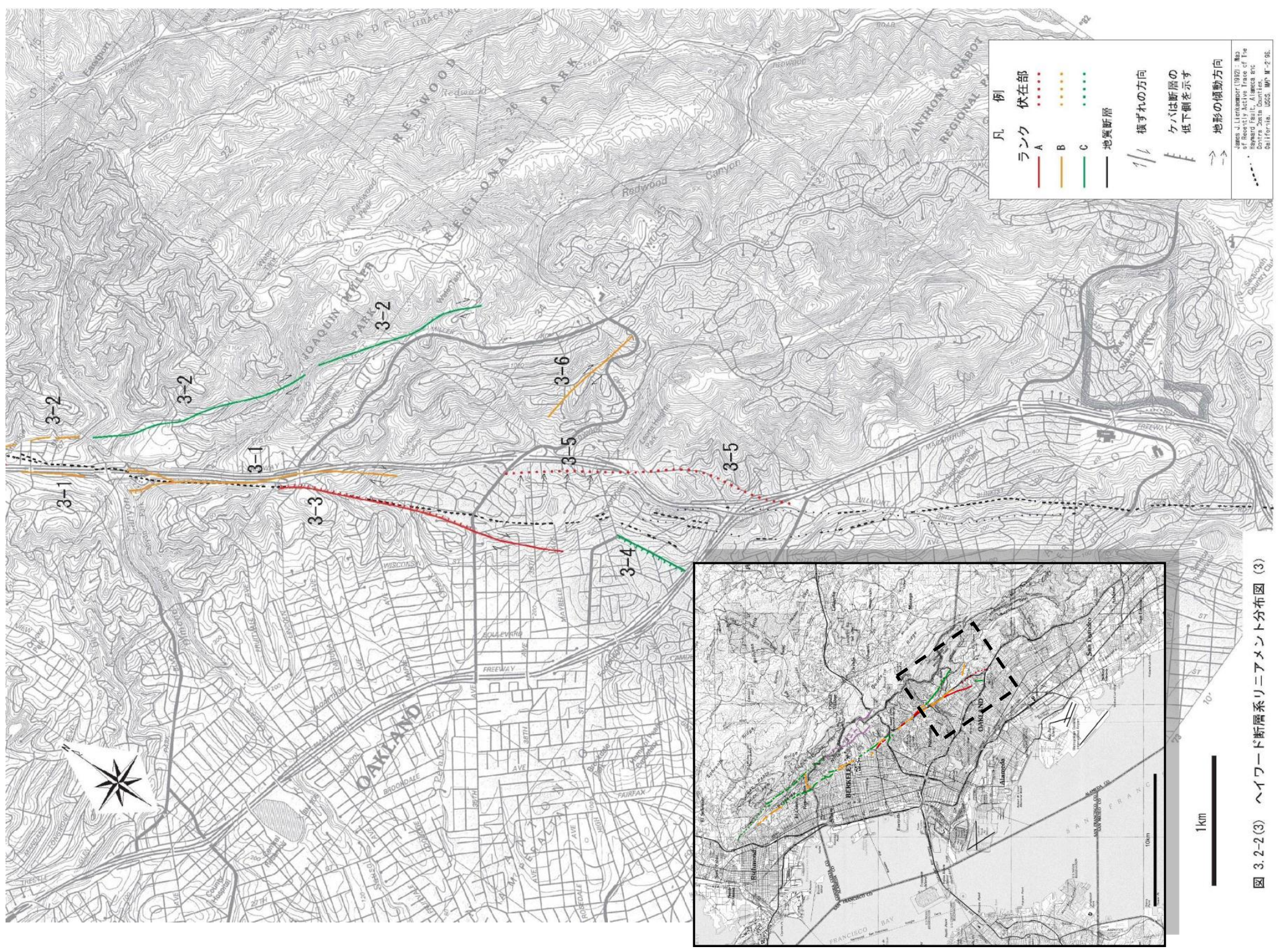

Figure 3-4 Lineaments associated with the Hayward Fault system (3). (Kiho et al., 2009) 
Table 3-1 List of identified lineaments. (Kiho et al., 2009)

\begin{tabular}{|c|c|c|c|c|c|}
\hline トレースNo. & ランク & 伏在 & 走向 & 長さ(km) & 地形形態 ${ }^{*}$ \\
\hline $1-1$ & B & & NE & 2.4 & rs \\
\hline $1-2$ & C & & NE & 2.4 & rs, d \\
\hline $1-3$ & C & & NE & 1.2 & $\mathrm{rs}, \mathrm{s}$ \\
\hline $1-4$ & C & & NE & 0.7 & ss \\
\hline $1-5$ & C & 0 & NE & 9.1 & v \\
\hline $1-6$ & $B, C$ & & EW & 1.0 & Ro/r \\
\hline $1-7$ & $A, B$ & & NE & 0.4 & rs \\
\hline $2-1$ & $B, C$ & & $\mathrm{NNE} \sim \mathrm{NE}$ & 5.3 & ss,Ro/v \\
\hline $2-2$ & $A, B$ & & NE & 1.7 & rs \\
\hline $2-3$ & $B, C$ & & ENE & 2.7 & $r s, w$ \\
\hline $2-4$ & $G$ & & NE & 4.1 & $c, v$ \\
\hline $2-5$ & G & & NE & 3.2 & $\mathrm{c}, \mathrm{v}$ \\
\hline $3-1$ & $A, B$ & & NE & 5.0 & s, Ro/v,pr \\
\hline $3-2$ & $\mathrm{~A}, \mathrm{~B}, \mathrm{C}$ & & NNE & 3.6 & $\mathrm{v}, \mathrm{Ro} / \mathrm{r}, \mathrm{Ro} / \mathrm{v}$ \\
\hline $3-3$ & A & & NE & 2.3 & $\mathrm{rs}, \mathrm{Ro} / \mathrm{v}$ \\
\hline $3-4$ & C & & NS & 0.7 & Ro/v \\
\hline $3-5$ & A & 0 & NE & 2.4 & $p$ \\
\hline $3-6$ & B & & EW & 1.0 & ss \\
\hline
\end{tabular}

* : rs 逆向き崖, $\mathrm{d}$ 凹地, $\mathrm{s}$ 崖, $\mathrm{ss}$ 急斜面, $\mathrm{v}$ 直線状谷, $\mathrm{Ro} / \mathrm{r}$ 右横ずれの尾根, $\mathrm{Ro} / \mathrm{v}$ 右横ずれの谷, $\mathrm{w}$ ウインドギャップ, c 鞍部, pr プレッシャーリッジ, p 傾斜 


\subsubsection{Analysis of site information}

\subsubsection{Geologic information}

In FY 2007, a literature survey was conducted in an effort to develop fault classification based on geologic and hydrologic properties. Results from this literature survey (of published peer-review journals), which focused on fault hydrology, showed that there was no clear correlation between the type of fault (i.e. normal, reverse, and strike-slip) and hydrologic properties. However, a comprehensive study of fault characteristics (such as change in fault properties along the fault length, variations in fault geometry, spatial heterogeneity, and internal structure) may give indications of how fault and fault zones could potentially affect local and regional hydrology.

As described in the report entitled "Development of Hydrologic Characterization Technology of Fault Zones," faults can directly affect the hydrology of a region by obstructing flow, changing flow direction, and affecting fluid chemistry. Faults will also change the physical properties of surrounding bedrock by changing rock porosity, permeability, conductivity and stress field. In our previous study, we stated that there is a lack of hydrologic data on fault zones at well scale in the literature. Most available information on fault hydrologic properties, i.e., porosity and permeability, comes from outcrop samples. The main problem with using these outcrop (and small core) samples for measuring hydrologic properties is that they do not incorporate large faults and fractures. Consequently, porosity and permeability values can be underestimated. In these samples, hydrologic properties are affected by localized scale, stress-relief, and weathering processes. Therefore, we emphasize the importance of drilling studies across fault zones in determining the in situ transport properties.

In order to evaluate this subject in detail, which revealed to be limited, a site within the Lawrence-Berkeley National Laboratory (LBNL) was selected to further examine the relationship between fault and hydrology.

\subsection{Regional Geology and Tectonics}

The geology of the San Francisco Bay Area is intertwined with some of the most complex and active geology in the world. The California geology is a result of plate 
subduction, active volcanoes, and faults along plate boundaries. The bedrock age ranges from Jurassic to Pliocene (see Figure 3-5). The oldest rock in the Bay Area region is the Jurassic to Cretaceous age (200-65 Ma) Franciscan assemblage, which was originally deposited in a deep marine environment and trench deposits. It was subsequently accreted during the plate subduction along the coast of Northern California. Over more than 100 million years of subduction, accretion brought together many types of Mesozoic rock we now see in the Bay Area. Extensive tectonic activity uplifted and folded the Franciscan mélanges, which consisted of exotic blocks of basalt, chert, limestone embedded in matrix of sheared greywacke and shales.

To the east of the Bay Area, a thick sequence of clastic submarine fan and basin plain deposits filled the forearc basin, between the accretionary wedge of the Franciscan and subduction-related volcanic arc (the present location of the Sierra Nevada batolith). This thick sequence of over 14,000 $\mathrm{m}$ is the Great Valley Sequence. The contact between the Franciscan and Great Valley Sequence is by fault, where discontinuous and dismembered fragments of the Coast Range Ophiolite crop out.

In the Eocene, about 25-30 millions year ago, there was a change in the tectonics when the Pacific plate met the North American plate. Subduction stopped along the contact of the two plates, and the Pacific plate began to slide northward past the North American plate along a transform boundary, the San Andreas Fault (Atwater, 1998; Sloan and Karachewski, 2006). These tectonics created shallow basins and mountain ranges. The basins were filled by marine as well continental sediments. Many varieties of sediments - future conglomerate, sandstone, shale, and chert-accumulated in these basins. These include the deposition of the Claremont and Orinda formations. Most of these sediments have been tightly folded. The diverse topography in the San Francisco Bay Area region has been also affected by faulting that has occurred since the Cretaceous. As the subduction continued into the Tertiary period, local faulting broke up extensive trenches in which sediments had been accumulating.

During the late Tertiary, volcanic lava flows were produced by local vents associated with fault movement. These flows created most of the volcanic rock in the San Francisco Bay region, largely basalts and andesites. Examples of this volcanism are: Quien Sabe volcanics (11-13 Ma), East Bay Hills volcanics (9-10.5 Ma), Sonoma volcanics (2.6-8 
Ma), and Clear Lake volcanics (2-10,000 Ma) (Graymer et al., 2002; Sloan, 2006).

Although the dominant movement between the Pacific and North America plates is strike-slip, about 3.5 million years ago, a small change in plate motion took place. The Pacific and North American plates begun to collide at a slight angle instead of just sliding past each other, resulting in transpression (Atwater, 1998). Sloan and Karachewski (2006) indicated that $90 \%$ of the movement between plates is strike-slip and $10 \%$ or less is compressional. Folding and faulting are the main processes involved in transpression. Good examples of hills in the San Francisco bay region resulting from transpression are Mt. Diablo and Mt. Tamalpais.

\begin{tabular}{|c|c|c|c|c|c|c|}
\hline Era & Period & Epoch & Group & Formation & Lithology & Deposition/Deformation \\
\hline \multirow{5}{*}{ 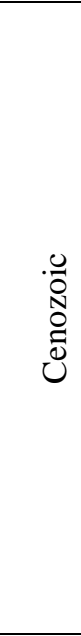 } & Quaternary & $\begin{array}{l}\text { Pleistocene/ } \\
\text { Holocene }\end{array}$ & & $\begin{array}{l}\text { Colluvium/ } \\
\text { Landslide } \\
\text { deposits }\end{array}$ & $\begin{array}{l}\text { Clays and silts and } \\
\text { weathered material }\end{array}$ & $\begin{array}{l}\text { Resulted from } \\
\text { erosional process }\end{array}$ \\
\hline & \multirow{4}{*}{ Late Tertiary } & $\begin{array}{l}\text { Late Miocene - } \\
\text { Pliocene }\end{array}$ & $\begin{array}{l}\text { Contra } \\
\text { Costa }\end{array}$ & Moraga & $\begin{array}{l}\text { Volcanic flows of } \\
\text { basalt and andesite; } \\
\text { tuff }\end{array}$ & \begin{tabular}{|l|} 
Lava flow related to \\
eruption of Bald Peak \\
and Round Top volcanoes
\end{tabular} \\
\hline & & $\begin{array}{l}\text { Miocene-Plioce } \\
\text { ne }\end{array}$ & $\begin{array}{l}\text { Contra } \\
\text { Costa }\end{array}$ & Orinda & $\begin{array}{l}\text { Poorly consolidated } \\
\text { sandsone, siltsone, } \\
\text { claystone, occasional } \\
\text { conglomerate }\end{array}$ & $\begin{array}{l}\text { Flood plan or alluvial to } \\
\text { shallow lake depositional } \\
\text { environment. } \\
\text { Unconformity over } \\
\text { Claremont Fm. } \\
\end{array}$ \\
\hline & & \begin{tabular}{|l|} 
Miocene-Plioce \\
ne
\end{tabular} & San Pablo & Briones (?) & sandstones & \begin{tabular}{|l|} 
shallow marine \\
environment
\end{tabular} \\
\hline & & Middle Miocene & $\begin{array}{l}\text { Monte- } \\
\text { rey }\end{array}$ & Claremont & $\begin{array}{l}\text { Siliceous shale, chert, } \\
\text { siltstone, occasional } \\
\text { sandsotne }\end{array}$ & $\begin{array}{l}\text { Marine deposition; } \\
\text { well interbedded, folded, } \\
\text { fractured and faulted and } \\
\text { overturned beds. }\end{array}$ \\
\hline \multirow[t]{2}{*}{ 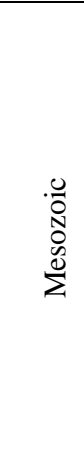 } & \multirow[t]{2}{*}{$\begin{array}{l}\text { Cretaceous to } \\
\text { Jurassic }\end{array}$} & & $\begin{array}{l}\text { Great } \\
\text { Valley } \\
\text { Complex }\end{array}$ & $\begin{array}{l}\text { Coast Range } \\
\text { Ophiolite } \\
\text { (CRO) and } \\
\text { Great Valley } \\
\text { Sequence } \\
\text { (GVS) }\end{array}$ & $\begin{array}{l}\mathrm{CRO}=\text { rocks of upper } \\
\text { mantle (serpentine) to } \\
\text { basalt } \\
\mathrm{GVS}=\text { marine } \\
\text { sedimentary rocks } \\
\text { (sandstone, shale, } \\
\text { conglomerate, } \\
\text { volcanic eroded } \\
\text { material) }\end{array}$ & $\begin{array}{l}\text { Fore-arc basin sediments } \\
\text { over } 10 \mathrm{~km} \text { thick over } \\
\text { oceanic rocks. }\end{array}$ \\
\hline & & & & Franciscan & $\begin{array}{l}\text { Pillow basaslts, } \\
\text { cherts, mélanges of } \\
\text { greywacke and shale }\end{array}$ & $\begin{array}{l}\text { From ocean spread center } \\
\text { to subduction and } \\
\text { accretion process. } \\
\text { Sheared and faulted. }\end{array}$ \\
\hline
\end{tabular}

In summary, the bedrock exposed in the Berkeley hills is highly deformed by extensive folding and faulting that has occurred since Cretaceous time, with very strong deformation occurring during the Pliocene epoch. The bedrock has been folded into a series of northwest trending anticlines and synclines, which are offset by faulting (Page,

Figure 3-5 Regional stratigraphy

1950; Graymer et al., 2002; HWL, 1982). 


\subsection{Geology of LBNL and Surrounding Areas}

Lawrence-Berkeley National Laboratory (LBNL) is located in the hills of Berkeley, eastern side of the San Francisco Bay Area, California. The bedrock at LBNL consists of Cretaceous and Miocene sedimentary rock overlain by volcanic flows. They are part of a homocline of the Great Valley sequence that gently dips $20-30^{\circ}$ to the northeast. The homocline is disrupted by the Wildcat Fault in the eastern part of LBNL (LBNL and Parsons, 2000).

\subsection{Claremont Formation}

The oldest rock in the study area is the Miocene age Claremont Formation, which is part of the Monterey Group. Rock from the Claremont formation is about 14-16 million years old and consists of well-consolidated, moderately weathered, light yellow siliceous shale and bedded chert, intercaleted with thin layers of siltstone. The Claremont Formation is regionally and locally folded and commonly overturned; bedding dip varies from northeast to southwest. Compared to surrounding bedrock, cherts are generally weather-resistant, forming some of the steeply slopes hills in the area (Untermman, 1935; Page, 1950; Graham et al., 1984).

Cherts at LBNL are described as light brown to yellow or gray and locally black silicified, thin to thick bedded to laminated, and moderately weathered. The chert is interbedded with gray to brown shale laminae and small amounts of light brown to white sandstone that occurs as dikes, beds, and boudins. Both the cherts and sandstones are weak to strong. All lithologies are intensely to closely fractured (LBNL and Parsons, 2000; Galpin, 1994).

\subsection{Orinda Formation}

The Orinda Formation is part of the Contra Costa Group and includes alluvial-fluvial sequences and lacustrine sequences (Graham et al., 1984). In the study area, it overlies the Claremont cherts unconformably (Jones and Curtis, 1991). The Orinda Formation comprises a succession of stacked fluvial, fining upward sequences (channelized gravel-to-cobble conglomerate, coarse grain sandstone to marron and green-gray sandy mudstone) and lenticular conglomerate units, some of which are 
separated by thick mudstone intervals (Graham et al., 1984). The non-marine unconsolidated sediments, primarily sandstone, siltstone, and conglomerate, are interbeded with volcanic rock. The Orinda Formation was originally deposited in a shallow lake or alluvial fan environment, except for the lowest portion, which may have been deposited in a shallow marine basin. The sediments deposited in marine environment is described as the San Pablo Group.

The Orinda Formation within LBNL is described as mudstone sand and fine- to medium-grained sandstones ranging in color from blue-to greenish gray to reddish-brown, and intensely-to-mildly fractured, friable, and little-to-moderately weathered (LBNL and Parsons, 2000).

\subsection{San Pablo Group}

The San Pablo Group is characterized by fossiliferous shallow marine sandstones. As described by Graham et al. (1984), the Orinda Formation is genetically linked to the San Pablo Group as a shallow marine equivalent by widespread interfingering with the Brione sandstone (Contra Costa Group). They both display the same Franciscan provenance in the sandstone.

The presence of the San Pablo Group at LBNL is not well documented. This fossiliferous marine sandstone, which contains bivalve and plant fossils, was discovered in the eastern portion of LBNL near Building 85 (Geo/Resources Consultant, 1994), and was thought by D.L. Jones to be part of the San Pablo Group (LBNL and Parsons, 2000). However, there is still uncertainty in defining the extent of this Group within the study area. A queried San Pablo Group is used by WLA (2008) trench studies near Building 74, but J. Baldwin (personal communication, 2008) agreed that the lack of fossil makes it difficult to differentiate the sediments of the San Pablo Group and Orinda Formation. Therefore, given the lack of exposure and radiometric dating data from fossils found in this group, there was no attempt to distinguish it from Orinda formation.

\subsection{Moraga Volcanics}

The Moraga volcanics overlies and interfingers with the Orinda Formation. It consists of alternating volcanic flows of basalt, andesite, and agglomerate, along with 
occasional tuffaceous sediments. The Moraga volcanics consist of up to ten basaltic volcanic flows, with interbedded volcaniclastic sediments (Curtis, 1989). It is primarily a result of Lower Pliocene (9-10.2 Ma) activity. The eruption of the Grizzly Peak volcanics constitutes the first evidence of fracturing along the Hayward trend (Graham et al., 1984). Outcrops of the Moraga are found in the north to northwest part of the study area and are typically highly fractured.

\subsection{Colluvium and Landslide Material}

The steep topography and high hills surrounding LNBL has been extensively evaluated by geotechnical consultants. Their geological and geotechnical studies show that a large part of the LBNL property is composed of landslide and colluvium deposits. Large masses of landslide, composed primarily of the Moraga Formation, has been mapped near the study area. The masses are generally lenticular in cross section, and several are elongated in plan view (LBNL and Parsons, 2000). The thickness of colluvium/landslide material varies from 5 to $40 \mathrm{ft}$ deep.

\subsection{Geological Structures}

\subsection{San Andreas Fault}

The San Andreas Fault system of coastal California is one of the best-known transform fault systems in the world. It is part of the boundary between the Pacific and North America plates. The right-lateral strike slip fault has accommodated over $330 \mathrm{~km}$ of displacement since Neogene. In the San Francisco Bay Area, especially in the East Bay, the San Andreas Fault splays into many subparallel fault zones. Those fault zones includes the active Hayward-Rogers Creek-Maacama (commonly referred to as the Hayward Fault), Calaveras-Sunol, Concord-Green Valley, and Greenville fault zones (Graymer et al., 2002). They are characterized by northwesterly-trending faults (N3040W). The San Andreas Fault system runs approximately 15-20 miles west of LBNL. The study area is primarily influenced by the Hayward Fault, which consists of a set of northwest-striking, right-lateral strike-slip faults. The study area is situated in a seismically active area of California, with a known history of earthquake events such as 
the 1906 and 1989 events along the San Andreas Fault, and the 1868 along the Hayward Fault (Figure 3-6).

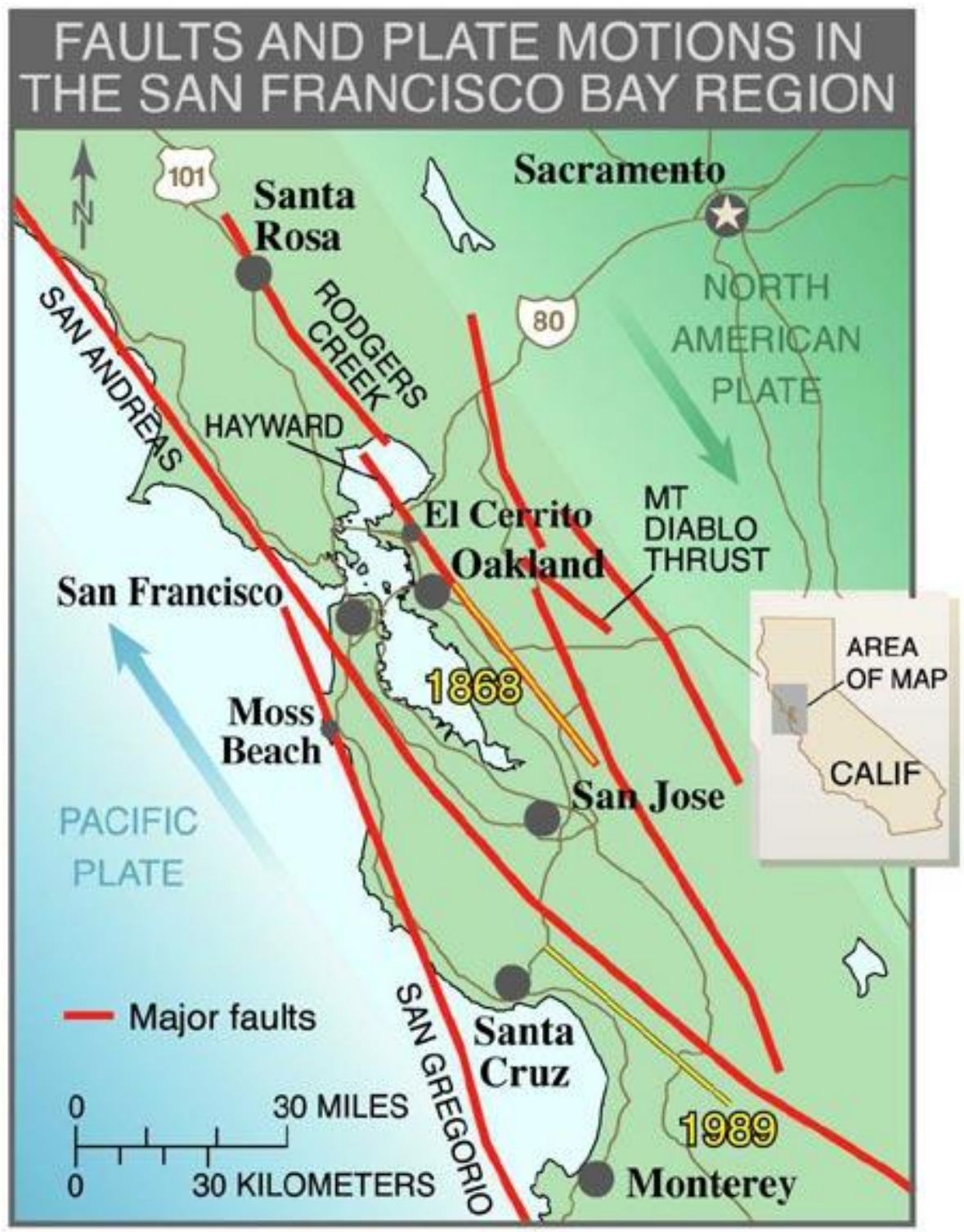

Figure 3-6. Faults and plate motions in the San Francisco Bay Region (USGS). Yellow lines show the location of two major earthquakes.

\subsection{The Hayward Fault}

The Hayward fault system, which runs northward and parallel to the San Andreas Fault system, initiated about 12 million years ago. The East Bay Hills, including where Berkeley is now, are actively rising at present, squeezed upward between two major faults, the Hayward Fault and the Calaveras Fault. The Hayward Fault is one of the main 
branches of the San Andreas Fault system sharing the same relative motion, i.e., a right-lateral strike slip movement. It trends N30W and runs from an area southeast of San Jose to San Pablo Bay. The fault is around $100 \mathrm{~km}$ long, parts of which are either locked or creeping. The Hayward Fault crosses the eastern border of the UC Berkeley campus, which is creeping at a rate of about $5 \mathrm{~mm} / \mathrm{year}$ (Simpson, 2000), crossing the football stadium, as shown in Figure 3-7 and Figure 3-8. Most subtle geomorphic expression in the LBNL has been removed by new development, erosion, and landslide. However, in the region, some clear geomorphic expression still remains, such as a linear northwest-trending zone of geomorphic features, subtle stream offset, and beheaded channels, as shown in the LIDAR image (Figure 3-8). The last major earthquake on the Hayward fault occurred in 1868, with an estimated magnitude of 7.0. The Hayward Fault is a prime candidate for a magnitude 7 earthquake within the next 30 years (USGS, 2008).

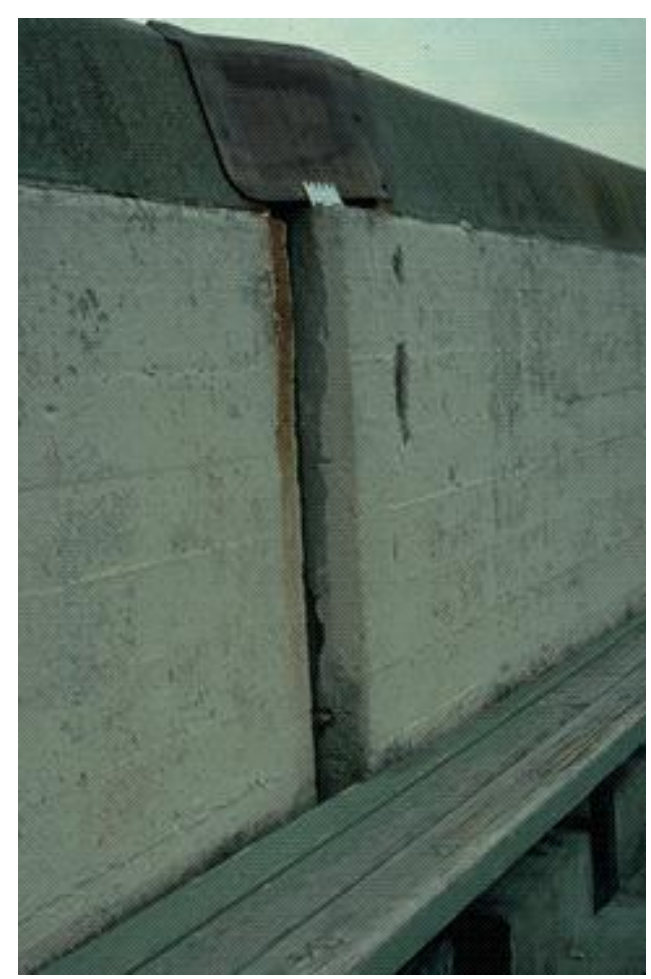

Figure 3-7. Displacement of the U.C. Berkeley Memorial Stadium wall as a result of the movement of the Hayward Fault 

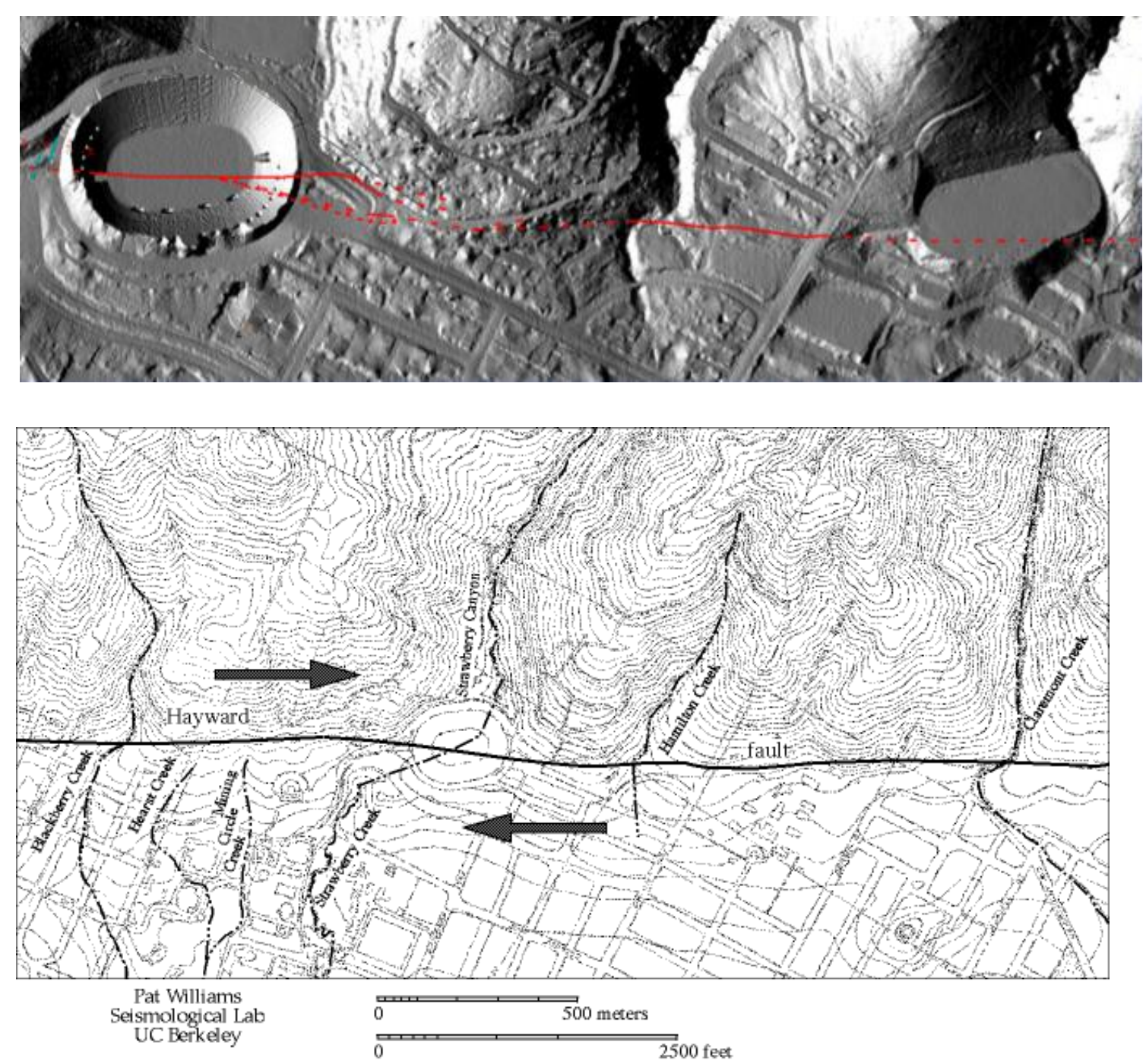

Figure 3-8. Top: LIDAR image (top) from USGS showing the trace of the Hayward Fault crossing the Memorial Stadium and displaced streams. Source: http://pubs.usgs.gov/fs/2008/3019/fs2008-3019.pdf.

Bottom: a topographic map illustrating the Hayward Fault. Source:

http://seismo.berkeley.edu/hayward/ucb_fault.html

\subsection{Uplift of the Berkeley Hills}

During late Miocene (c.a. $12 \mathrm{Ma}$ ), uplift of the Berkeley hills started with the initiation of the Hayward Fault as a result of the transition to transform-margin setting. The uplift has also changed the sedimentation patterns in the East Bay, specifically changing the deposition in the area from marine to non-marine sediments. Paleogeographic reconstruction of the East Bay suggests changes in sedimentation 
pattern during the deposition of the Orinda and San Pablo groups. The eruption of the Grizzly Peak volcanics constitutes the first tangible evidence of fracturing along the Hayward Fault (Graham et al., 1984). Deformation and uplift west of the Hayward Fault spread eastward activating the Moraga fault thrust.

\subsection{Wildcat Fault-Previous Studies}

The Wildcat fault is a secondary splay fault associated with the Hayward fault. It cuts late Cenozoic strata, striking subparallel to the Hayward Fault. The fault runs about one and one-half kilometers east of the Hayward Fault, and it has been identified as part of the San Andreas Fault system (LBNL and Parsons, 2000). The Wildcat Fault passes along the eastern margin of LBNL and runs from Oakland to Richmond. Regionally, the fault is difficult to map throughout its length and appears to be discontinuous, although it clearly truncates and offsets strata at many locations. At regional scale, the fault shows right-lateral strike-slip movement (Curtis, 1989), and local reverse movement has also been observed and described (Jones and Curtis, 1991). The history of the Wildcat fault at regional scale is summarized below:

- The Wildcat fault has been shown on geologic maps since the early 1900's. It was originally mapped by Lawson and Palache (1900).

- Untermann (1935) named the Wildcat fault as a long break in the Berkeley Hills. Its disturbance can be one-fourth of a mile $(400 \mathrm{~m})$ wide in some places. According to Untermann, the Wildcat fault is described as having a northwest-southeast trend generally dipping to SW. On his map, north of Strawberry Canyon, the fault follows the contact between cherts to the east and a series of sediments and volcanics to the west as part of the Orinda Formation. The saddles indicating the location of the fault near LBNL are the Little Grizzly Peak in the north and Sugar Loaf (named after Untermann, 1935) along the Fire Trail to the south. Shear zones, gouge, and slickensides in cherts are reported along road cuts north of Signal Hill and below Sugar Loaf, near Claremont Canyon. On the south side of Claremont Canyon, an outcrop of chert with bedding (N46W/82SW) shows horizontal striations. The disturbance zone varies from approximately $300 \mathrm{ft}(90 \mathrm{~m})$ to the west and a gouge zone of 18 inches $(46 \mathrm{~cm})$ to $8 \mathrm{ft}(2.4 \mathrm{~m})$ wide to the east. Sandstone of Sobrante (Lower Miocene) or of Cretaceous has been described south of Strawberry Canyon. The presence 
of older and higher beds to the west would also suggest elevation of the west side. North of Strawberry Creek up to Little Grizzly Peak, Untermann reported the contact of the Wildcat fault as between the Claremont chert in the east and the sediments (conglomerate, sandstone, and shales of reddish brown and greenish color) of the Orinda Formation. Untermann also describes several locations where he observed striation in cherts (varying from vertical to horizontal) as well the presence of a secondary fault along Strawberry Canyon. Further north, Untermann describe a horizontal displacement of 1320feet (402m) that was measured in the lava along the Wildcat Canyon, south of Cerrito creek. The fault follows the Wildcat canyon merging with the Hayward fault somewhere south of San Pablo bay. To the south the fault was mapped in the Claremont tunnel within the cherts and in the San Pablo tunnel as a contact between Orinda and Claremont. The fault plane was reported dipping steeply to the southwest.

- A major fault zone of about $30 \mathrm{ft}(9 \mathrm{~m})$ was partially exposed during the construction of the Broadway Tunnel in Oakland (Page, 1950). The fault cuts through the Claremont formation. The strata were highly fractured, locally contorted and cut by many irregular dikes (Page, 1950).

- The Wildcat fault is parallel to the Hayward fault and, according to Bishop (1973), eventually joins the Hayward Fault in the north near the San Pablo. Fault creep has been used as an indicator of fault creep along the north end of the fault. The evidence consists of a slight curb offset, pavement cracks, a deflected stream, and a break-in-slope. According to Bishop (personal communication in HLA, 1980), there are no known creep features along the Wildcat fault south of the El Cerrito-Richmond line.

Several geotechnical reports have been compiled since the middle 1970s to evaluate the geologic conditions of LBNL. The reports focus on potential geological hazards such as earthquake and landslides for construction of roads and buildings. In these geotechnical reports, the Wildcat fault has been assessed for its activity; however, no evidence of Holocene (last 11,000 years) deposit displacement in the area has been found. The study of the Wildcat fault in the LBNL is summarized below:

- Field notes by Korbay (1975), discussed in Gilpin (1994), documents a fault 
exposure in bedrock bench cut east of Building 84. The fault trend is $\mathrm{N} 15 \mathrm{~W}$ and dip 70NE.

- Korbay and Lewis, in HLA (1980), evaluated the Wildcat fault and cross faults north of the LBNL property line and Building 74. In Trench A, located in the north of LBNL property, the fault is described as consisting of several thin shears separating the green-red highly mottled clay of the Orinda sediments from sandstone of either the Sobrante or Claremont unit. It is described as two and one-half inches wide, with fine vertical striations on a plane striking N6W/vertical. Trench B normal to the cross fault was located SW of Building 74. After trenching up to $13 \mathrm{ft}(4 \mathrm{~m})$, they did not encounter the bedrock but rather a dark gray to black silty clay, as well as light-colored volcanic on the bottom of the trench. The investigators did not found any conclusive evidence of the cross fault in the trench.

- According to Curtis (1989), the Moraga Formation has been displaced approximately $6 \mathrm{~km}$ northwest, from a position adjacent to the volcanic center at Round Top along the Wildcat Fault.

- Jones and Curtis (1991) interpret the Wildcat Fault as a thrust fault associated with a fold and thrust belt attributed to left-stepping on the Calaveras-Hayward fault system.

- Gilpin (1994) conducted a review of previous geotechnical investigations of the Wildcat fault and provided an independent assessment of whether the fault is active. Galpin argued that ductile deformation observed in the Orinda at the Hazardous Waste Handling Facility excavation is part of the landslide, but the review by Korbey disagree that the vertical fault observed during HLA trench is result of landslide.

- Jordan (1997) observed that the Wildcat fault was exposed by the excavation of Building 84. The fault separates the sandstone of the Miocene San Pablo Group from chert and shales of the Miocene Claremont Formation. The fault gouge is approximately $14 \mathrm{~cm}$ to $1.5 \mathrm{~m}$. According to Jordan (personal communication), a very thin $(<1 \mathrm{~cm})$ dark vitreous material was observed in the fault near Building 74.

- Jones (personal communication) in LBNL and Parsons (2000) stated that the SanPablo Group exposed adjacent to the fault at LBNL may have been displaced 
from similar San Pablo Group rock, on the opposite side of the Wildcat Fault system that lies near Lake Chabot, $14 \mathrm{~km}$ to the south.

- Graymer (2000) in the regional geologic map of the East Bay, includes several traces of a fault cutting through the LBNL property. To the north, the fault traces merged near Grizzly Peak, while to the south, the faults are cut and displaced by two EW-oriented faults. According to Graymer (personal communication 2009), the main trace of the Wildcat fault is considered to the one in contact between the Claremont Formation in the east and the Orinda Formation in the west. The fault eventually merges with the Hayward Fault south of LBNL, near Oakland.

- In 2008, William Lettis and Associates (WLA) logged three trenches, T1, T2 and T3, about 2 meters south of the parking lot of Building 74. The trenches intersected the previously mapped locations of the Wildcat fault. In these trenches, cherts of the Claremont Formation were exposed in the eastern part and siltstone and sandstones of San Pablo Group were exposed in the west. The dip of bedded chert varies from $\mathrm{E}$ to $\mathrm{W}$, possibly due to a downslope creep process. Relict folding, S-type and chevron type, is described as affecting the bed dip. The Wildcat Fault was mapped in trenches T2 and T3, and it is described as a contact between the weathered chert and sandstone with silt and clay, grayish green to dark-reddish brown, described as belonging to the San Pablo Group. In T2, the fault strikes N50E/20E. The fault zone contains mottled clay that supports the chert-rich matrix (WLA, 2008). The same fault is observed in T3. The fault strikes N17 to N40 and dips 40-42E and is about a meter wide.

- Previous studies (i.e., HLA, 1974, 1980; WLA, 2008) indicated that the fault is not active because there is no evidence of fault movement in the sediments deposited in the past 11,000 years. The site is not located within the California Special Earthquake Fault Studies Zone (formerly referred to as the Alquist-Priolo Special Studies Zone) by the California Division of Mines and Geology (1992) in Kleinfelder (2001).

- Graymer (personal communication, 2009) argued that it is possible that the Wildcat Fault could have previously been a trace of the Hayward Fault and could possibly be one of the branches of a flower structure of the existing trace of the Hawyard Fault.

- Subsurface Consultants (1999) drilled numerous geotechnical drillholes near Bldg. 84 before it was constructed. Most of the drillholes were shallow and 
encountered only San Pablo or Claremont formation with the exception of G-13. In G-13 drillhole (Figure 3-9), it appears that the formation below Claremont is encountered, which is described as gray silty clay stone (Figure 3-10). One possibility is that G-13 had drilled through the Wildcat Fault and the formation encountered below the Claremont is the Wildcat Fault itself and/or San Pablo. Another possibility is that the formation is the Sobrante formation, which is conformant to the Claremont. Only deep drilling on the both side of the Wildcat Fault would clarify this ambiguity.

\subsection{Cross Fault}

Cross faults were originally mapped by Lawson and Palache (1900), Untermann (1935), and mentioned in Dames and Moore (1962). Untermann (1935) describes the presence of a secondary fault along Strawberry Canyon, striking N65W and steeply dipping to the NE, suggesting the possibility that the Wildcat Fault had been displaced by a cross-fault.

HLA (1974) reports a cross fault cutting through Building 74, although it was not observed either in borings or caissons, or exposed on the surface. It is based on relative exposure of the Orinda to Claremont shale on the cut slope. Then, in 1980, HLA trenched across the cross fault near Building 74. The thick colluvium deposit did not expose the fault. Jordan (2008, personal communication) mapped a fault behind Building 84 that merged with the Wildcat fault instead of cutting through it (see map by LBNL and Parsons, 2000). Therefore, owing to a lack of conclusive evidence showing that the cross fault displaces the Wildcat Fault, no further attempt was made to describe this fault.

\subsection{Folding and Thrusting}

Major Neogene and younger compression are recorded in the geology of the East Bay. It includes several east-verging fold and thrust belts, such as the Moraga Fault (Aydin, 1982). In the study area, cherts of the Claremont Formation are strongly folded, generally overturned to the east, and are probably repeated several times by faulting and folding (Jones and Curtis, 1991). The age of thrusting in the Berkeley Hills is now well 
constrained, with evidence of the Moraga Fault displacing rock as old as $8.4 \mathrm{Ma}$ (Jones and Curtis, 1991). 

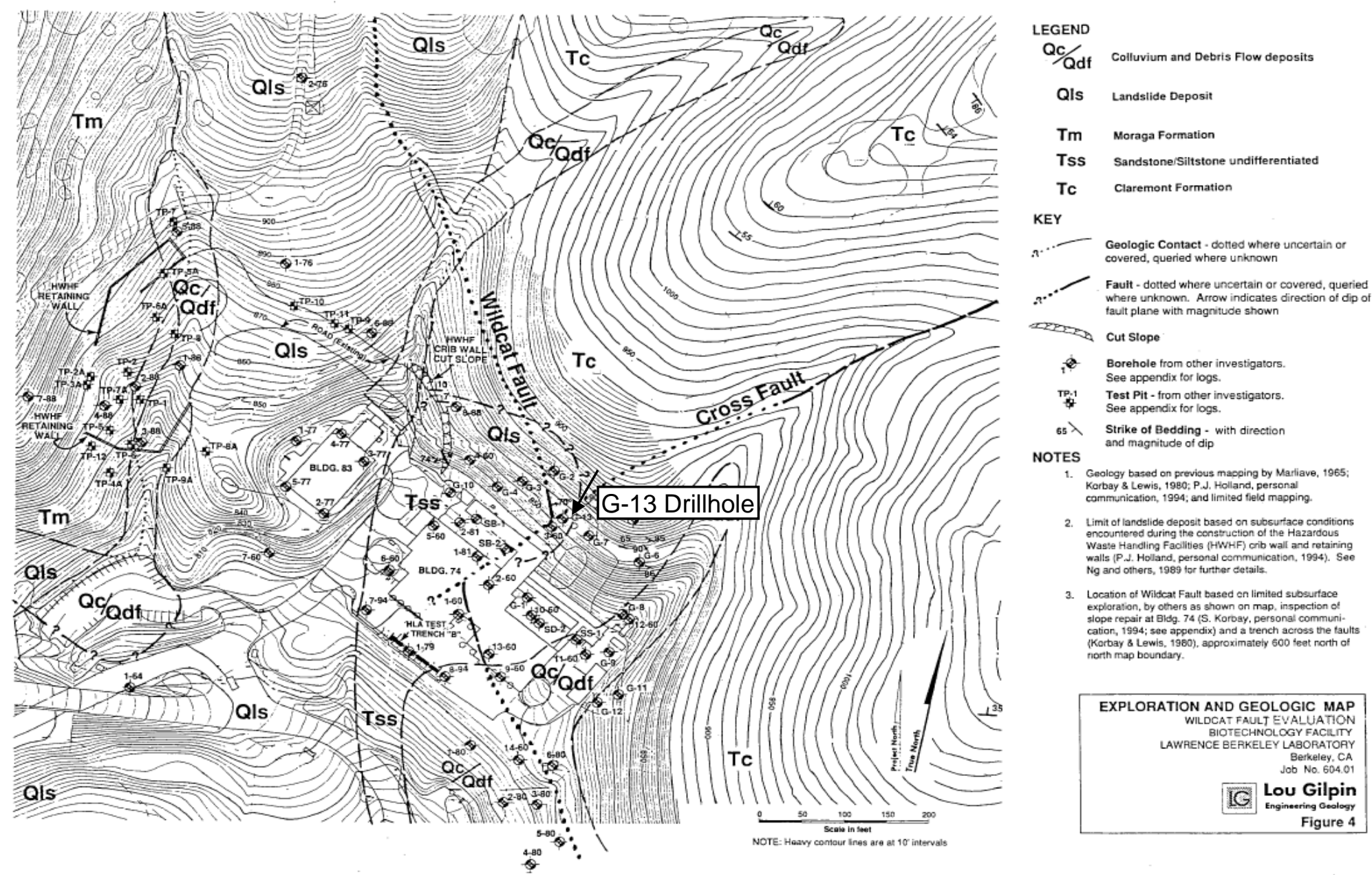

Figure 3-9. Locations of geotechnical boreholes near Bldg. 74(Subsurface consultants, 1994). 


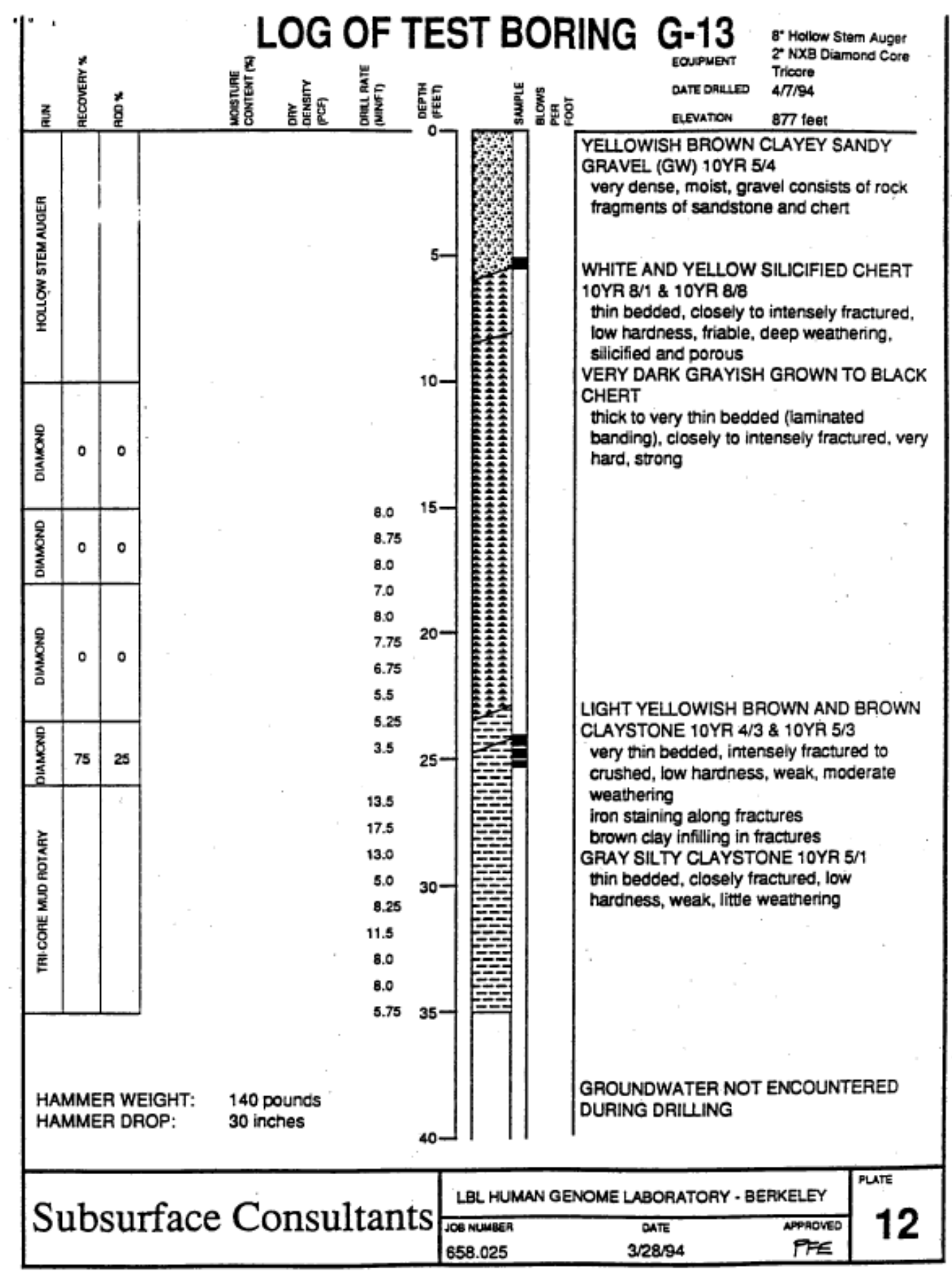

Figure 3-10. Borehole log of G-13 that encounters the Claremont chert formation and a claystone formation below it (Subsurface Consultants, 1994). 


\subsubsection{Geophysical Information}

LBNL の敷地内に於いて過去に物理探査が行われた例が数例存在する。LBNL 敷地の東部 の East Canyon では以前から存在が予測されていた East Canyon 断層（Figure 3-16 参照）を 確認する為に磁気探査(Magnetometer Survey)および屈折法探查、続いてトレンチ掘削が行わ れている（GeoResources, 1994）。Figure 3-11 に屈折法探査の測線、Figure 3-12 に磁気探 査の結果を示すが、いずれも結果は不明瞭であった。理由として古い地滑りのため被りが 複雑で、地震波速度や磁気異常がその影響を受けたと思われる。その後 2008 年に William Lettice Associates (以降はWLA)が行ったトレンチ調査でも East Canyon 断層は確認されてい ない。

その他に、LBNL の Old Town 地域で Figure 3-15 に緑の楕円で示寸箇所で高精度の反射法 地震探查と VSP(Vertical Seismic Profiling)が行われている（Daley et al, 1996; Daley, 2000）。 この調査は深部の石油探査などで有効な手法を浅部を扱う環境回復プロジェクトに応用す る目的で行われた。しかしながら、これらの調查も地滑り、地表堆積物、盛り土などの浅 部の複雑な地質の為、ノイズが多く解析が非常に困難で思うような結果が得られていない。

本プロジェクトの Wildcat 断層の調査に最も関連性が高いと思われるのが、Keinfelder (2001)による屈折法を使った調査である。この調査は Calvin Road を北に延伸する工事の予 備の岩盤調查として行われた。Figure 3-13 に緑の線で屈折法探査の測線を示す。これらの調 查はWildcat 断層のおよそ $40 \mathrm{~m} \sim 60 \mathrm{~m}$ 西側で断層にほぼ平行に行われている。Figure 3-14 に屈折法の解析結果を示す。それによれば、Line 1、Line 2 ともに地表から 9m 12m の 深度に基盤岩が存在すると考えられる。また Line 1 の地下の基盤岩は Line 2 に比較して倍 のP 波速度であり、Line 1 の下と Line 2 の下では基盤岩の種類が異なっている可能性がある。 これらの情報は次年度のボアホール掘削時の貴重な参考になると思われる。 


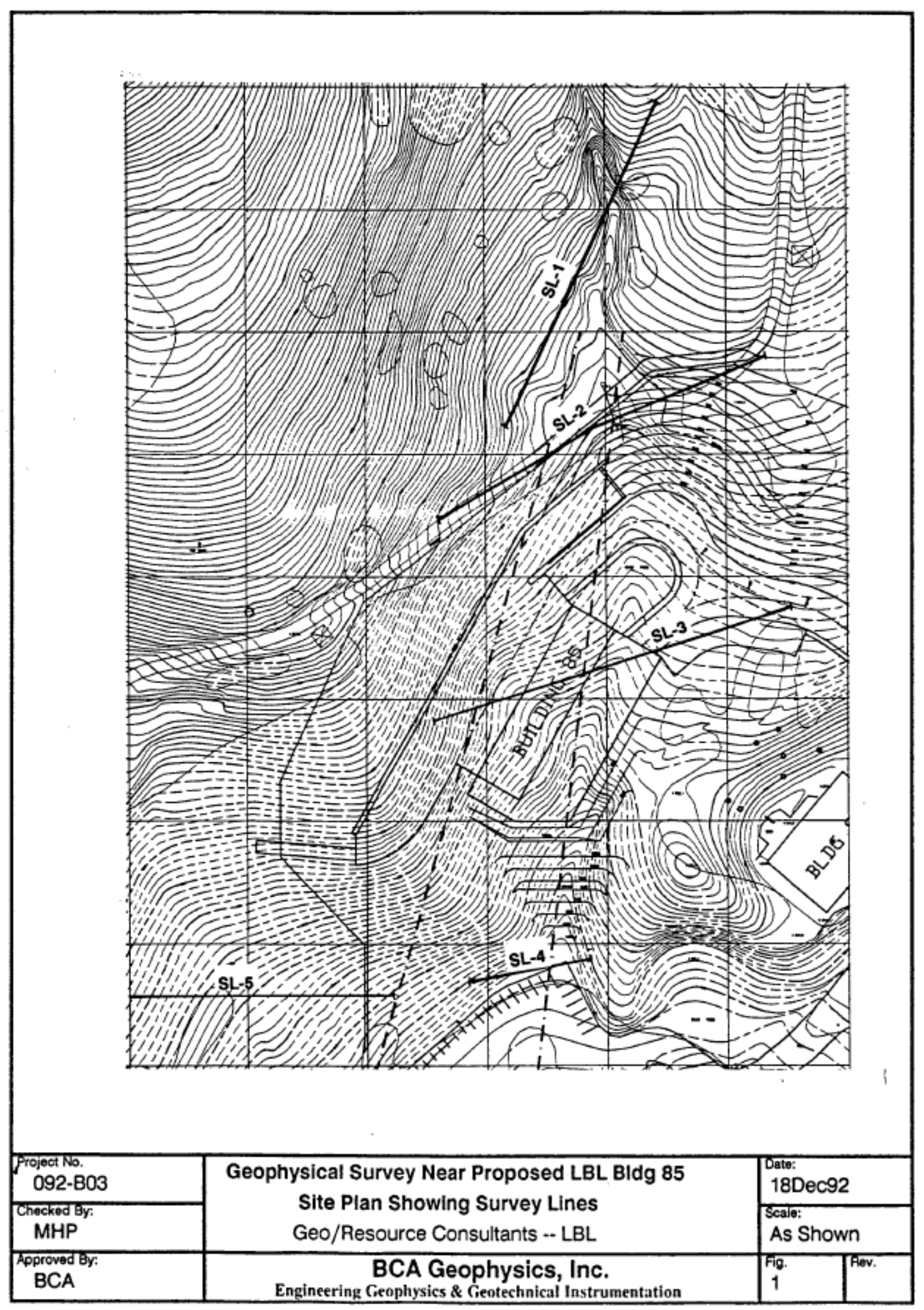

Figure 3-11 Seismic refraction lines conducted in the East Canyon. (Geo/Resource, 1994) 


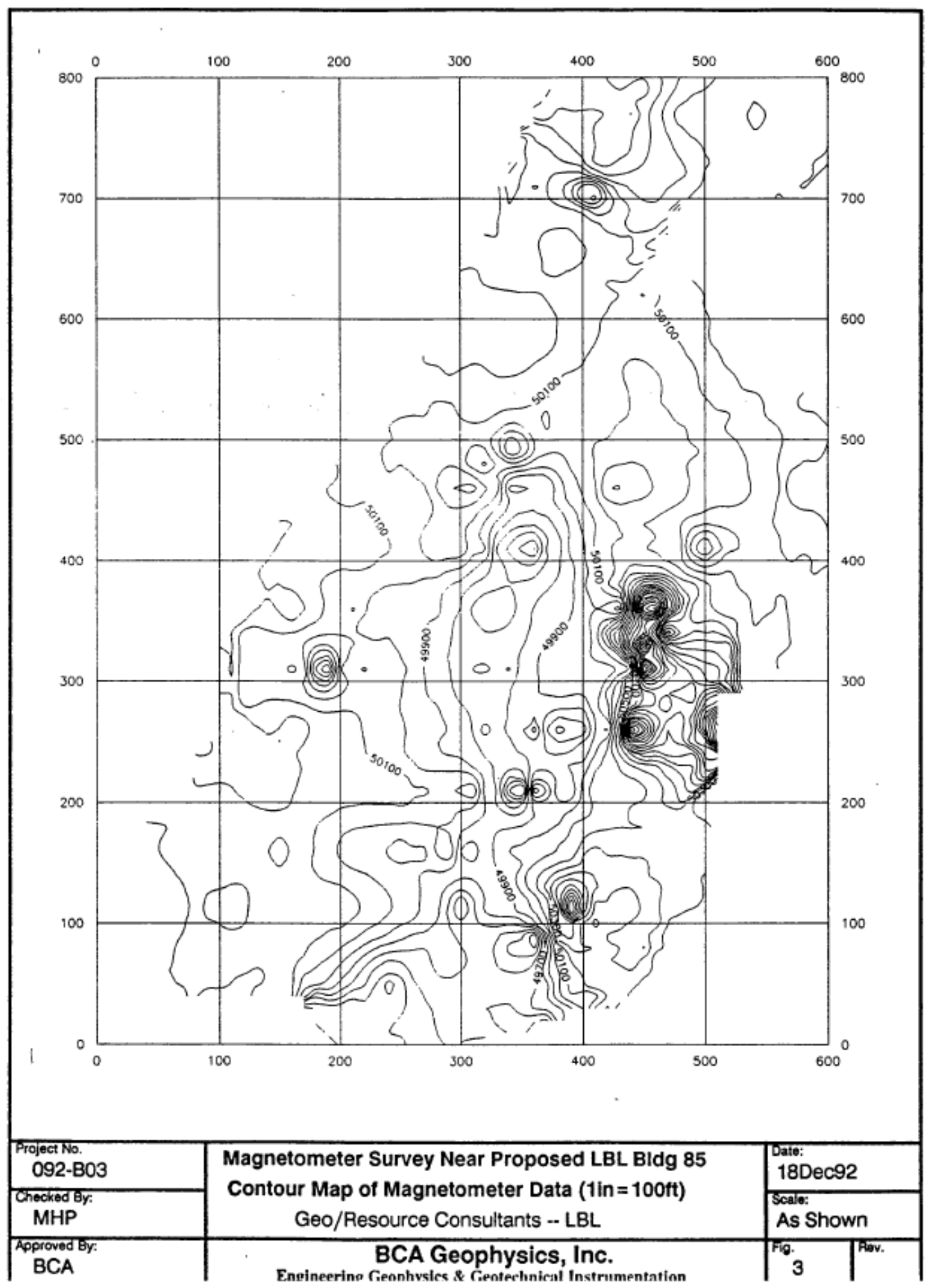

Figure 3-12 Magnetometer Survey in the East Canyon Area (Geo/Resource Consultants 


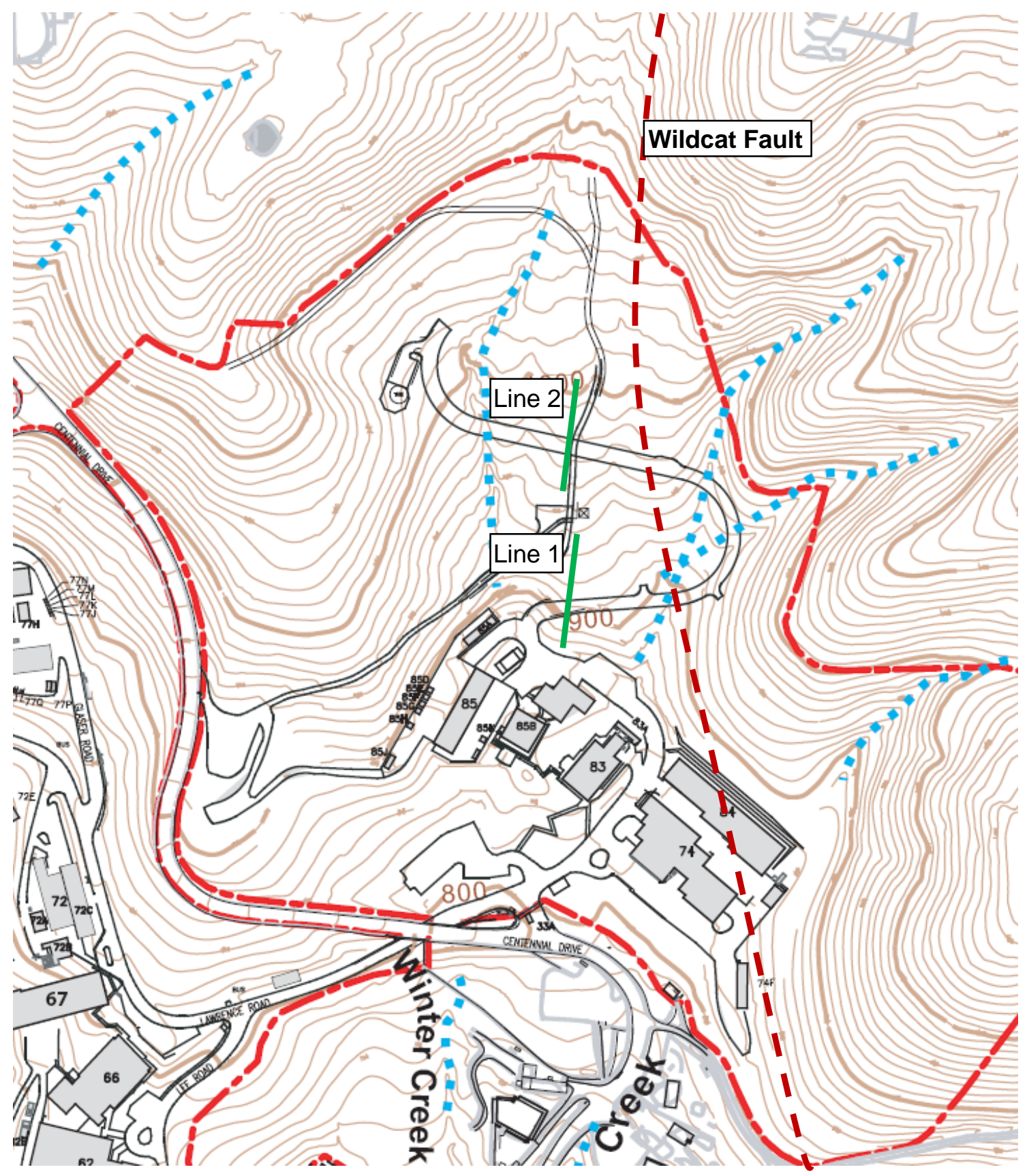

Figure 3-13. Seismic refraction lines conducted in 2001. 

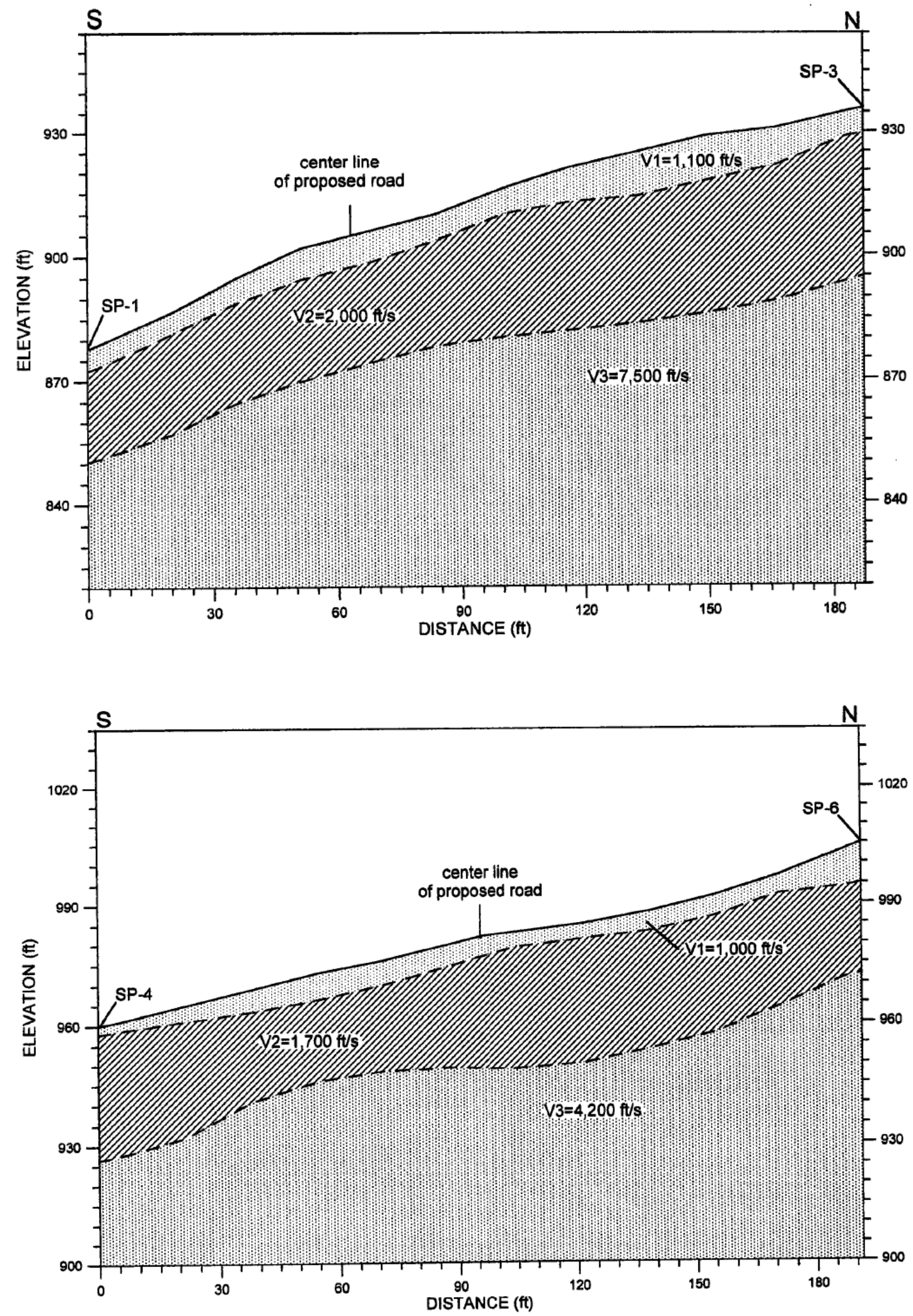

Figure 3-14. Seismic refraction profile form Line 1 (top) and Line 2 (bottom). 


\subsubsection{Hydrologic information}

\subsection{Boreholes}

LBNL のサイト環境回復プロジェクトによって掘削されたボアホールは浅部地下水の污 染状況を観測する目的である為、深度が比較的浅く（ 15m）、污染が及んでいないと考え られる Wildcat 断層の東側には 1 本も掘られていない。Figure 3-16に LBNLの地質図にボア ホールの位置、推定される断層のトレース、および湧水箇所を重祆合わせた図を示す。Figure 3-17 には木方他(2009)の考えた湧水メカニズムを示す。Figure 3-18 に Wildcat 断層の西側の 断層に近い既存の観測井の位置を示す。Figure 3-18 は Figure 3-15 に示す LBNL サイトの地 形図の南西に位置するの長方形で囲まれた部分の拡大図である。また、Table 3-2 にこれら の井戸の諸元を示す。

Figure 3-15にLBNLの北の丘の上に存在する Space Science Laboratory の敷地に地滑り対策 用に掘削された SSL-1、SSL-2 の位置を示す。SSL-1 はおよそ 110m、SSL-2 は 200m の深度 に掘削され、SSL-1 には、揚水ポンプが設置されており、地下水面が一定以上の高さになる とポンプの電源が自動的に入り排水するように設定されている。SSL-2 は現在のところ使用 されていない。

現状ではこれらの井戸に計測装置は設置されていないが、Wildcat 断層の水理テストを行 う際にこれらを地下水面の観測井として使うことが可能である。

\subsection{Hydrologic information}

LBNL(2000)によれば、Wildcat 断層の西側には Table 3-2 に示すように“?”付きでSan Pablo 層が存在すると考えられている。Figure 3-19 は Figure 3-18 に記載されているモニタリング 井で観測された地下水位のコンターマップを示す。これらのモニタリング井はケーシング が設置され、孔底近くにスクリーンを設けてあり、殆どが San Pablo 層に砂をパッキングし てある事から、San Pablo 層の水頭を表していると考えられる。図から明らかなようにWildcat 断層の西側の地下水面はほぼ地表面に平行に南に向かって低下している。しかしながら、 Wildcat 断層の東側にはボーリング孔が存在しないことから、図中の赤い破線で表される Wildcat 断層の東側の地下水面の分布は不明である。

木方他(2009)はLBNLの敷地全体に存在するボーリング孔で観測された水位を Kriging し、 ボーリング孔口の標高を Kriging した標高マップと比較した（Figure 3-20、Figure 3-21）結 
果、水位と標高が同じ傾向を示していることを指摘している。

Figure 3-22 および Figure 3-23 は MW74-94-8 と MW74-95-6 のそれぞれ過去 14 年間に渡る 降雨量と地下水位のデータのプロットである。MW74-95-6 と周辺の井戸はおそらく84 号棟 の建設の影響と思われる地下水位の上昇傾向が 97 年から 2006 年までみられる。また、2006 年冬の降雨量が少なかった為と思われる地下水位の低下が認められる。しかしながら、 MW74-94- 7 (not shown) と MW74-94-8 は過去 14 年間、一定で、その他の井戸も 30cm から $60 \mathrm{~cm}$ の降雨量に連動した季節変動はあるものの、ほぼ一定の水位を保っている。

Table 3-2 の井戸のうち、MW34-95-6 を除いた 5 本の井戸でスラグ試験および一部揚水試 験（MW74-92-13）を用いた水理試験を行った結果を併せて Table 3-2 に示す。これらの結果 はS San Pablo 層の透水係数は $3 \times 10^{-8} \mathrm{~m} / \mathrm{s}$ から $8 \times 10^{-6} \mathrm{~m} / \mathrm{s}$ である事を示している。

Wildcat 断層の近傍でボアホールを掘削すれば、Claremont、San Pablo、Moraga、さらに Orinda の各層に当たる可能性がある。LBNL(2000)による Claremont 層を除いた各層の透水 係数を Figure 3-24に示す。図から明らかなようにLBNLで見られる地層の透水係数は $4 \times 10^{-4}$ $\mathrm{m} / \mathrm{s}$ から $3 \times 10^{-12} \mathrm{~m} / \mathrm{s}$ までの 8 オーダーに渡る分布がある。火山岩の Moraga 層は平均が $10^{-5}$ $\mathrm{m} / \mathrm{s}$ に近い高い透水性を示しているが、主として亀裂による透水性であると考えられる。 Orinda 層は最もばらつきが大きく、砂と粘土の含有量に依存すると考えられる。

LBNL 東部の南側に隣接する Botanical Garden (Figure 3-15 参照)では庭園の東部の $2 、 3$ 箇所で季節に拘らず通年の湧き水が見られる。これらの箇所は概ね Wildcat 断層に沿ってお り、断層に関連した湧き水と考えられる。これはWildcat 断層がそれを横切る方向で透水性 が低く、標高の高い東側からの地下水が地表面に出てきていると仮説することが可能であ る。

Figure 3-27 に Widlcat 断層の周辺の古い湧き水の痕跡と Harding and Lawson Associates (1976) による湧き水の位置を示す。図から明らかなように、湧き水の痕跡が Wildcat 断層の トレースにほぼ平行に崩積土 $\left(Q_{c}\right)$ の外郭線上に並んでいる。これらの泉が East Canyon 断層のトレースを表すという学説もある。あるいは、崩積土の下に埋れている Wildcat 断層 から湧き出ていた水の痕跡と考える事も可能である。

\subsubsection{Geochemical Information}

Table 3-2 にリストされるモニタリング井において地化学成分の解析が行われている 
(LBNL, 2000)。Figure 3-25 にシュティフダイアグラムを示す。MW74-92-13 孔以外はすべて 類似した組成を示している。深度の浅さ、San Pablo 層の透水性の高さや降雨に連動した水 位変動から予想できるように年代の浅い天水性の地下水組成であると推測される。前出の ようにWildcat断層の東側においては、ボアホールが存在しない為、地化学データが無い為、 断層の両側での地化学成分の比較は出来ないが、今後東側に掘削するボアホールからのサ ンプルと比較すると興味深い。これらの井戸は地下水位の計測に加えて現在は 3 ケ月に一 度の割合で地下水のサンプリングが行われており、本プロジェクトのベースラインデータ として利用可能である。

木方他(2009)は各ボーリング孔における地下水の水質分析結果と地質の関連性，断層との 関連性を調べOrinda Formation の方が主要溶存イオン量が大きく, $\mathrm{Na}-\mathrm{HCO}_{3}$ 型の水質が多く, Great Valley Group では主要溶存イオン量が少なく, $\mathrm{Ca}-\mathrm{HCO}_{3}$ 型の水質が多いと考えた。木 方他(2009)によれば、Great Valley Group では透水係数が大きく，地下水流速が早いために， それほど水質の進化が進んでおらず，炭酸塩鉱物の溶解よって水質が形成されており， Orinda Formation は透水係数が小さく, 流動性が低いため, 溶存イオン量が Great Valley Group に比べて大きく, 炭酸塩鉱物の溶解後に $\mathrm{Ca}$ と $\mathrm{Na}$ の陽イオン交換が発生するため, $\mathrm{Na}-\mathrm{HCO}_{3}$ になっているものと推測している。

また、木方他(2009)はLBNL の水質データを用いて主成分分析を実施している(Figure 3-26)。 それによれば、水質の変化はスティフダイアグラムと同様、主要溶存イオン量と陽イオン 交換 $\left(\mathrm{Ca}-\mathrm{HCO}_{3}\right.$ 型 $\rightarrow \mathrm{Na}-\mathrm{HCO}_{3}$ 型 $)$ の変化が支配的であると結論付けている。 
Table 3-2. Well information near the Wildcat Fault (Modified from LBNL, 2000)

\begin{tabular}{|l|c|c|c|c|c|c|c|c|}
\hline Well ID & $\begin{array}{c}\text { UC Grid } \\
\text { Northing }\end{array}$ & $\begin{array}{l}\text { UC Grid } \\
\text { Easting }\end{array}$ & $\begin{array}{c}\text { Total depth } \\
(\mathrm{ft})\end{array}$ & $\begin{array}{c}\text { Top of casing } \\
\text { elevation (ft) }\end{array}$ & $\begin{array}{c}\text { Casing } \\
\text { Diameter (in) }\end{array}$ & $\begin{array}{c}\text { Completion } \\
\text { interval (ft) }\end{array}$ & $\begin{array}{c}\text { Permeability } \\
(\mathrm{m} / \mathrm{s})\end{array}$ & $\begin{array}{c}\text { Geologic units exposed to } \\
\text { sandpack }\end{array}$ \\
\hline $74-92-13$ & -355.80 & 5301.10 & 48.2 & 834.90 & 2 & $38.2-48.2$ & $8 \times 10^{-6}$ & San Pablo (?) \\
\hline $83-92-14$ & -354.70 & 5254.65 & 59.0 & 830.09 & 2 & $48-58$ & $2.7 \times 10^{-8}$ & San Pablo (?) \\
\hline $74-94-7$ & -508.66 & 5233.24 & 44.2 & 819.82 & 2 & $33.5-43.5$ & $4.6 \times 10^{-8}$ & San Pablo (?) \\
\hline $74-94-8$ & -594.5 & 5343.25 & 30.4 & 815.74 & 2 & $20-30$ & $6.3 \times 10^{-7}$ & Colluvium/San Pablo (?) \\
\hline $74-95-6$ & -354.67 & 5334.83 & 49.5 & 838.16 & 4 & $35-50$ & - & San Pablo (?) \\
\hline $83-95-7$ & -285.14 & 5246.70 & 47.0 & 840.75 & 4 & $36-46$ & $1.7 \times 10^{-6}$ & San Pablo (?) \\
\hline
\end{tabular}




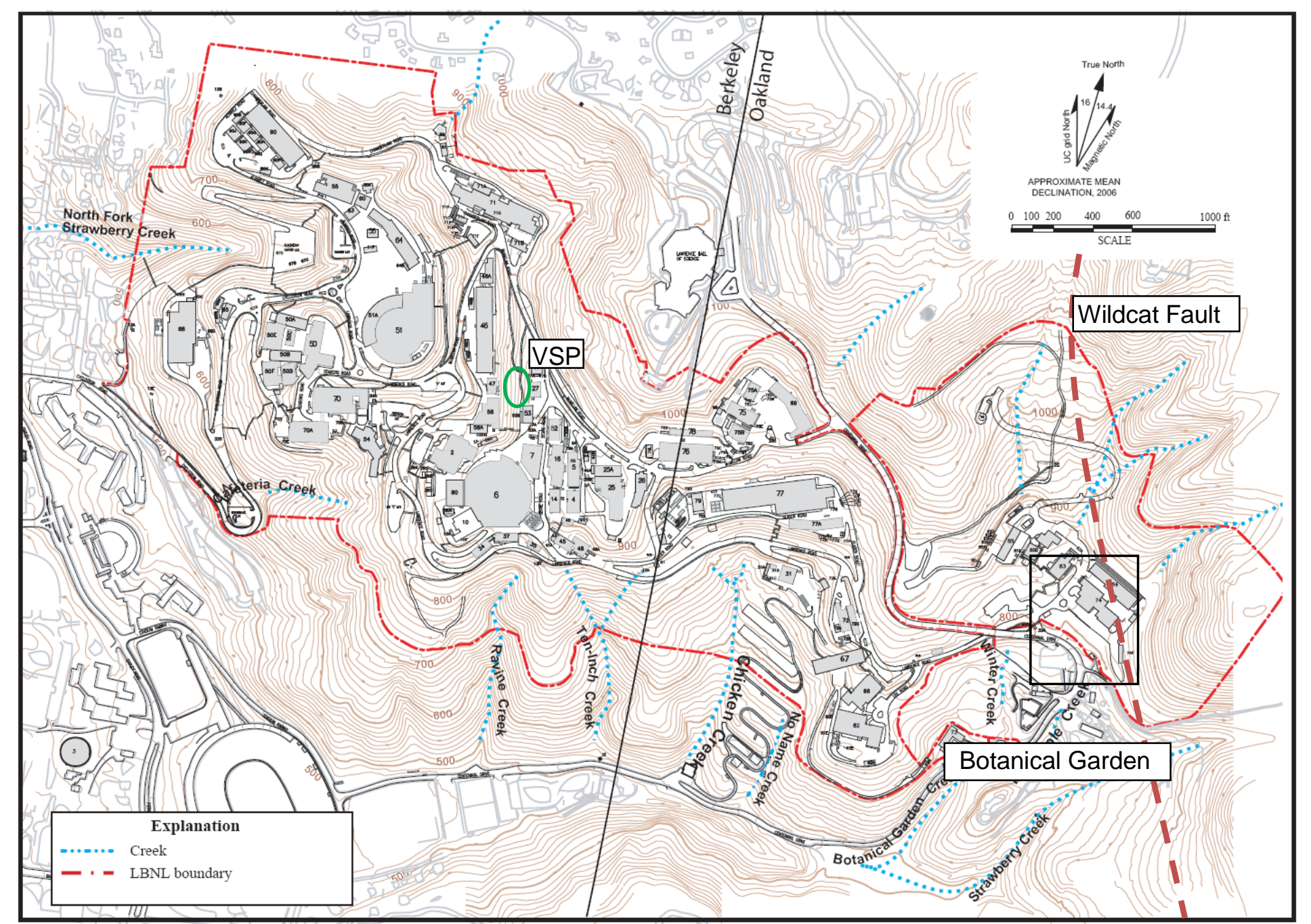

Figure 3-15. LBNL site map with topography and the Widcat Fault trace. 


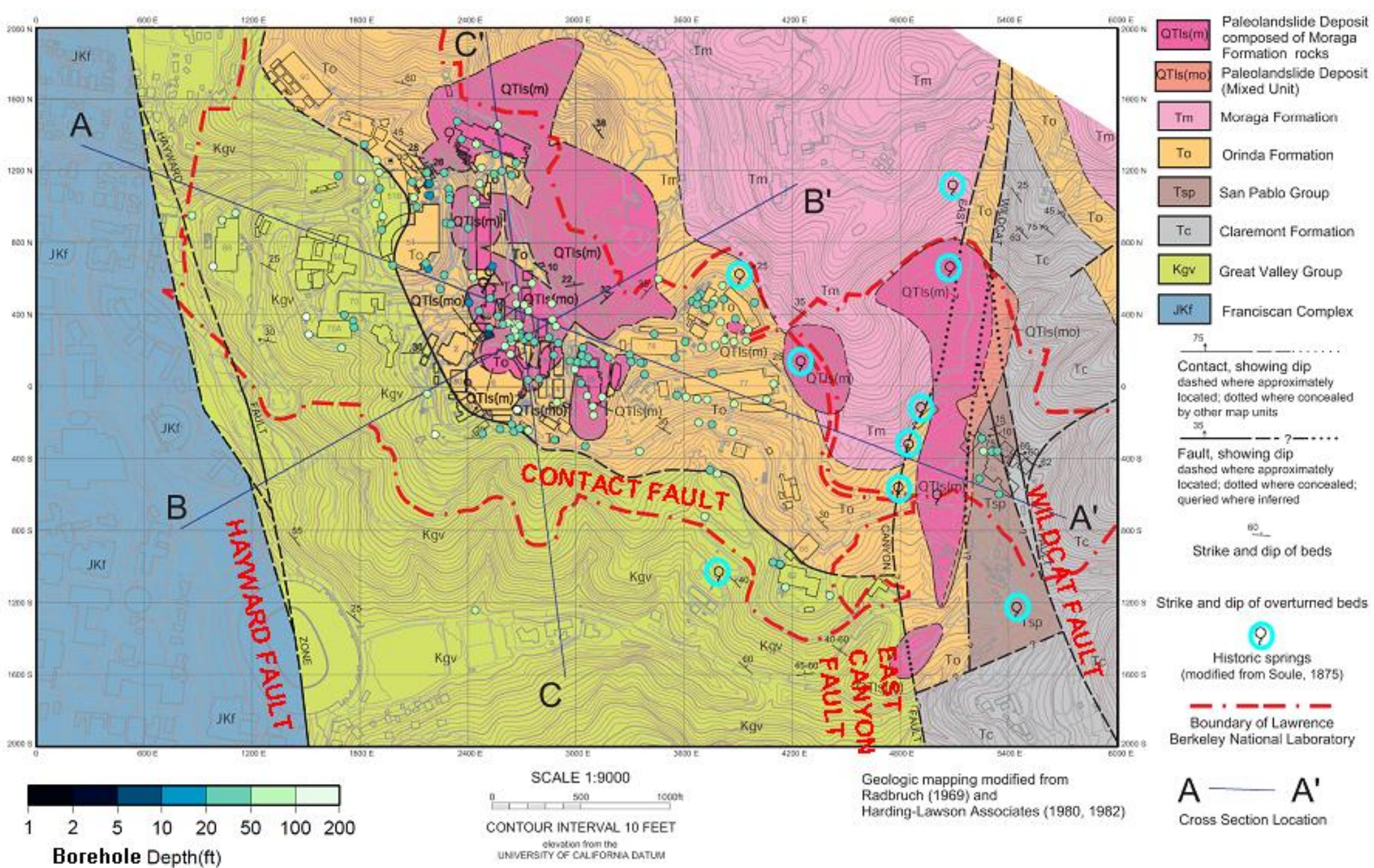

Figure 3-16 LBNL geologic map superimposed with suspected fault traces, borehole locations and spring locations (LBNL 2008) 


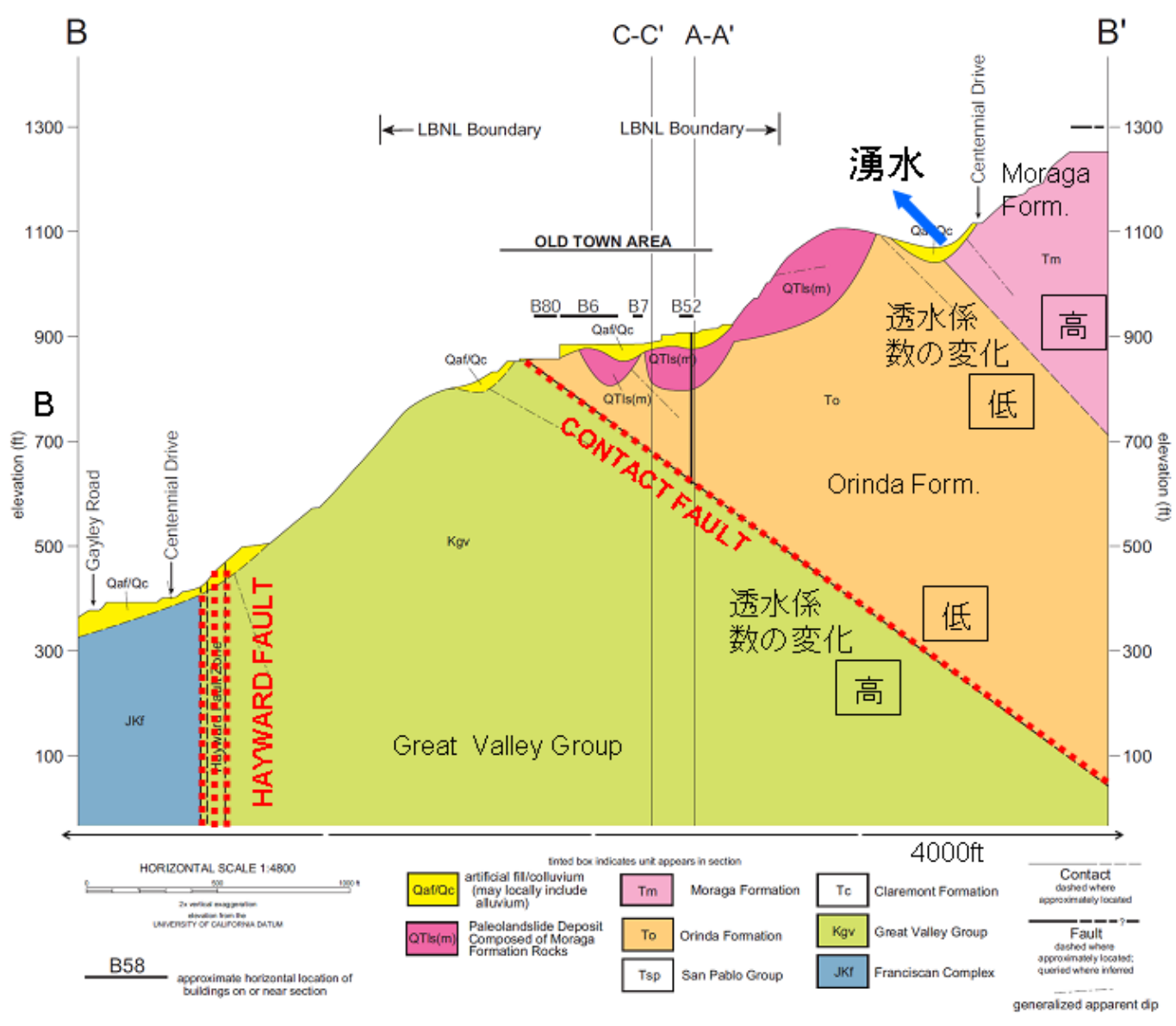

Figure 3-17 Mechanism for spring occurrence (木方他、2009) 


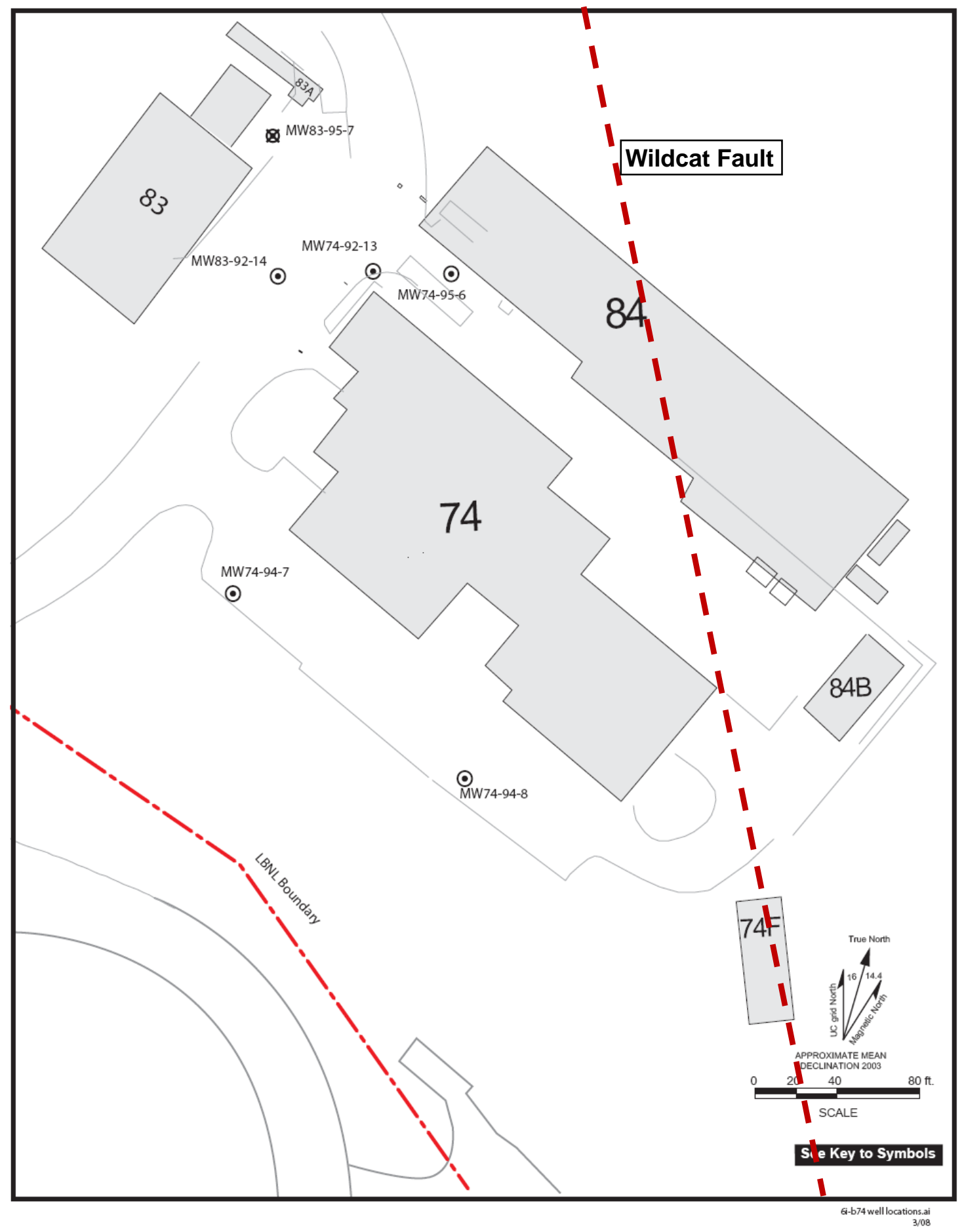

Figure 3-18. Existing monitoring well locations near the Wildcat Fault. Enlarged section from Figure 3-15 


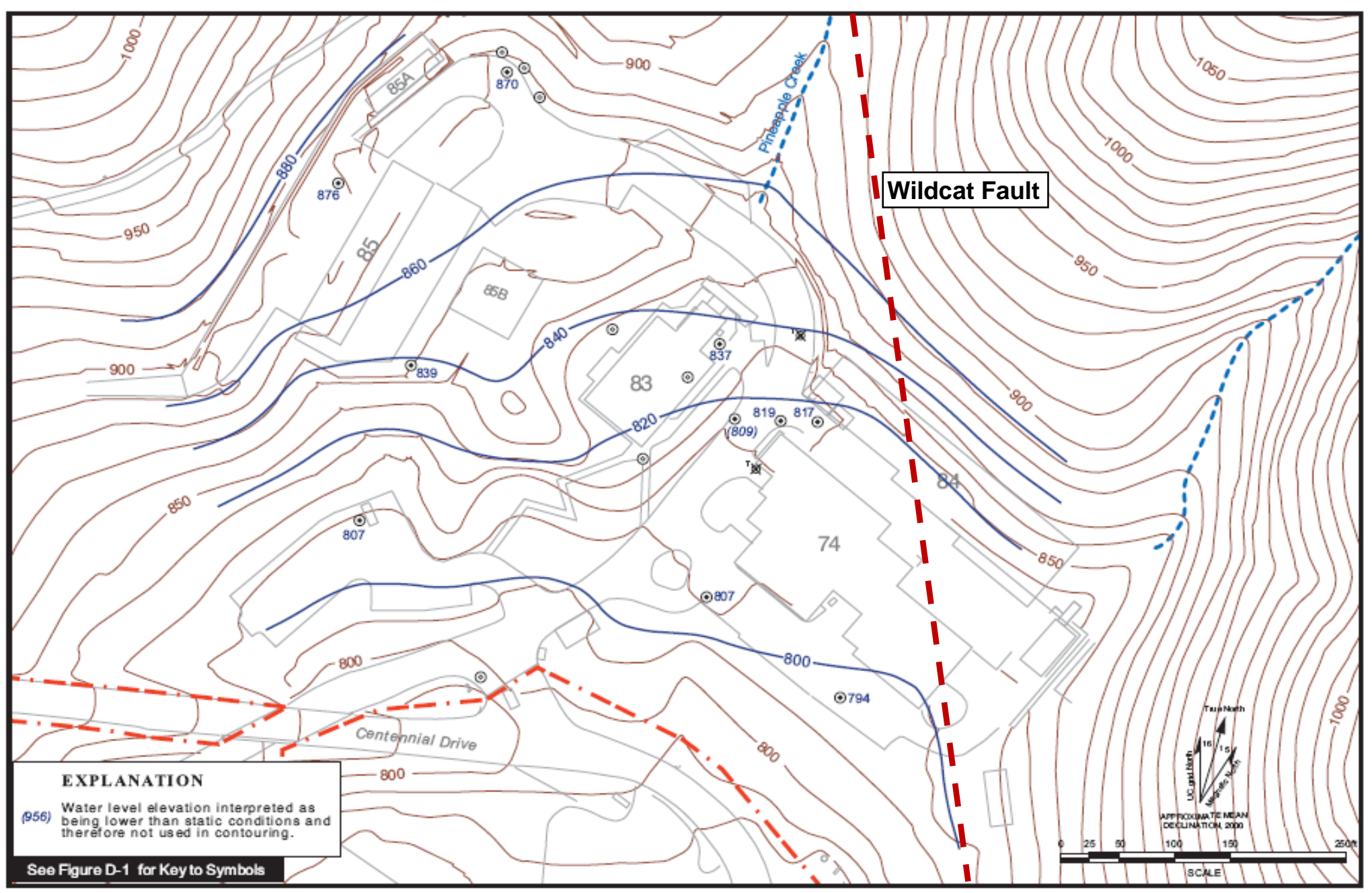

Figure 3-19. Water level contour near the Wildcat Fault (Modified from LBNL, 2000). 


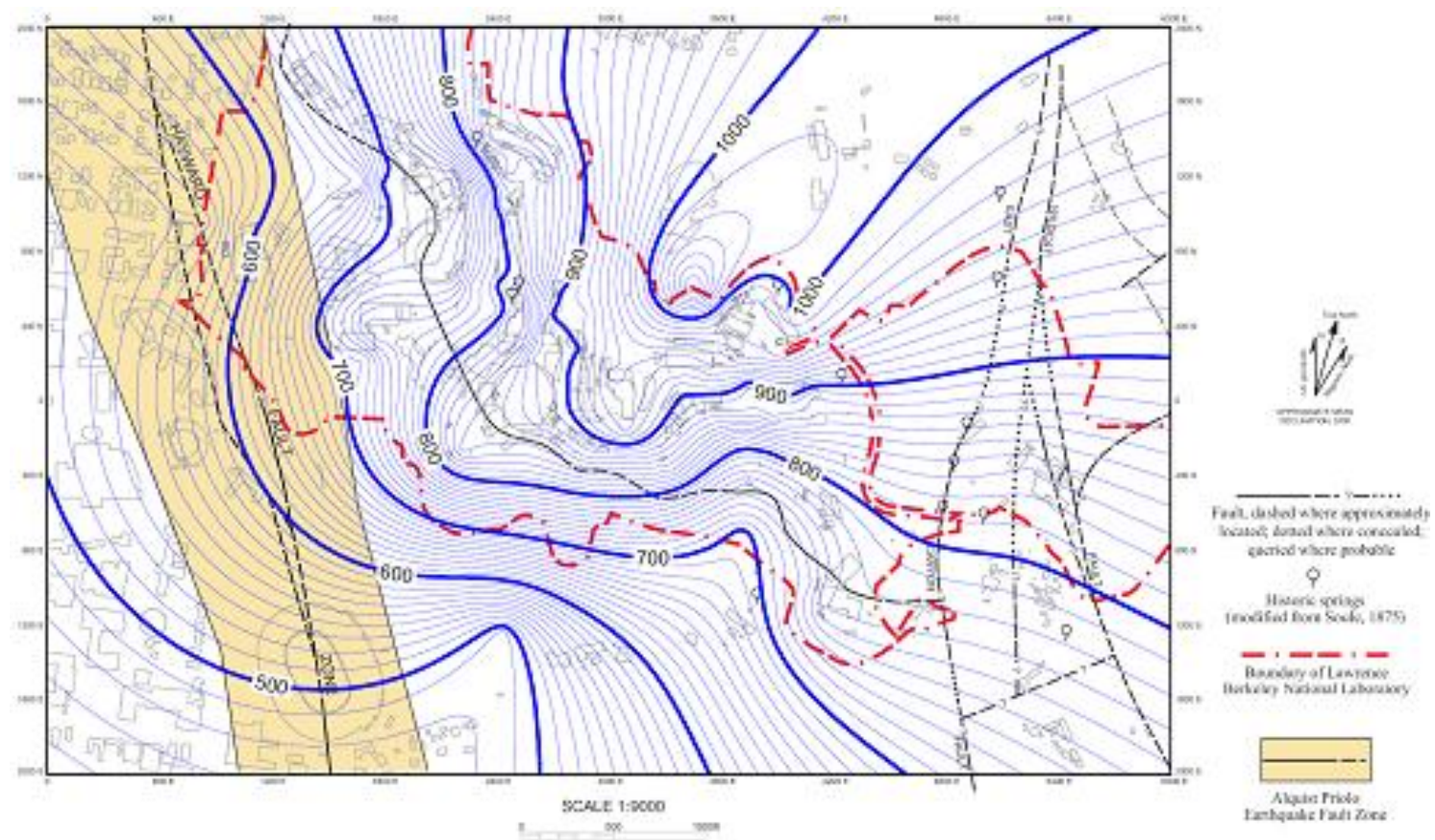

Figure 3-20 Krieged contour map of water levels in boreholes. (Kiho et al., 2009)

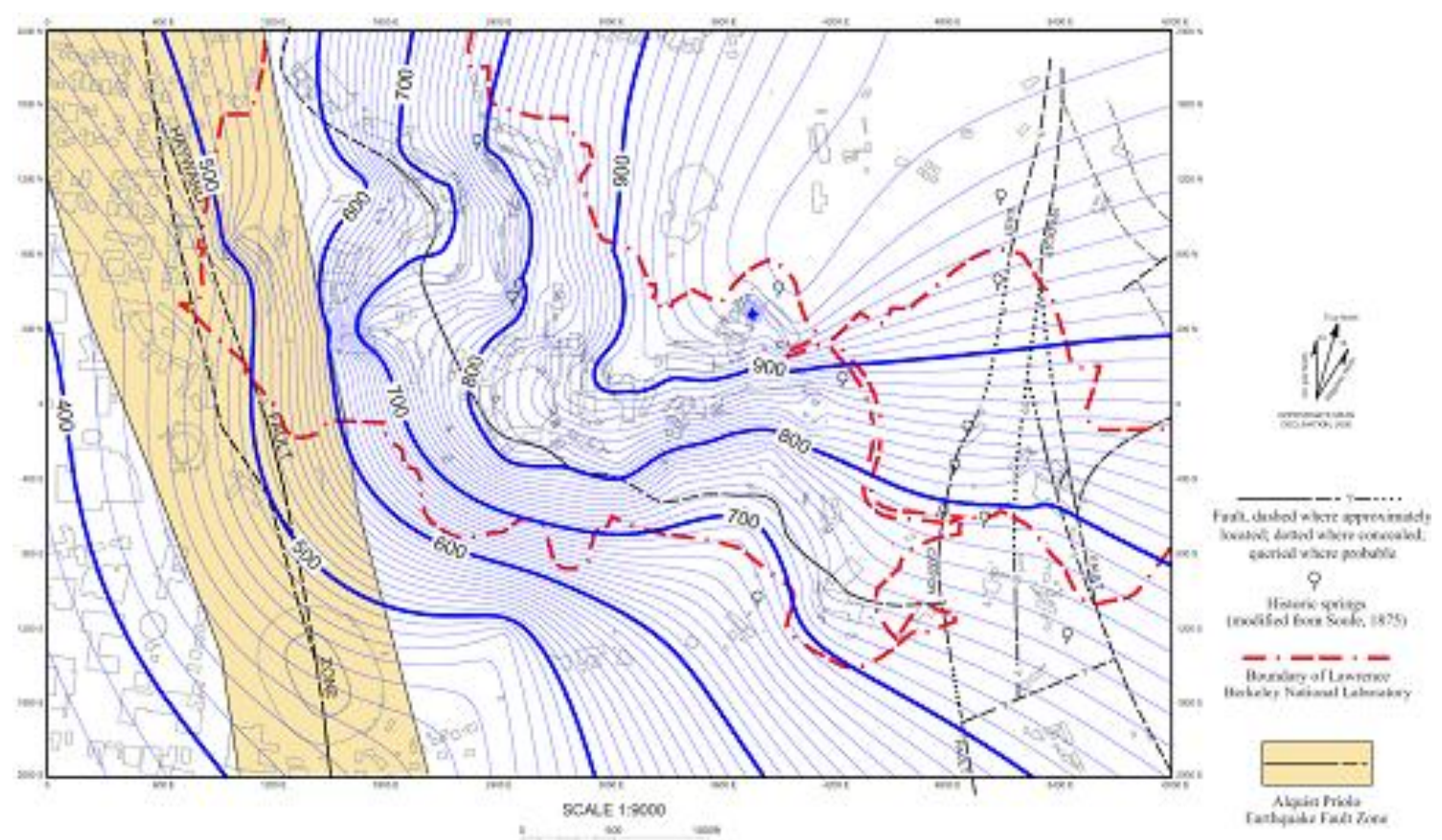

Figure 3-21 Krieged contour map of borehole elevations. (Kiho et al., 2009) 


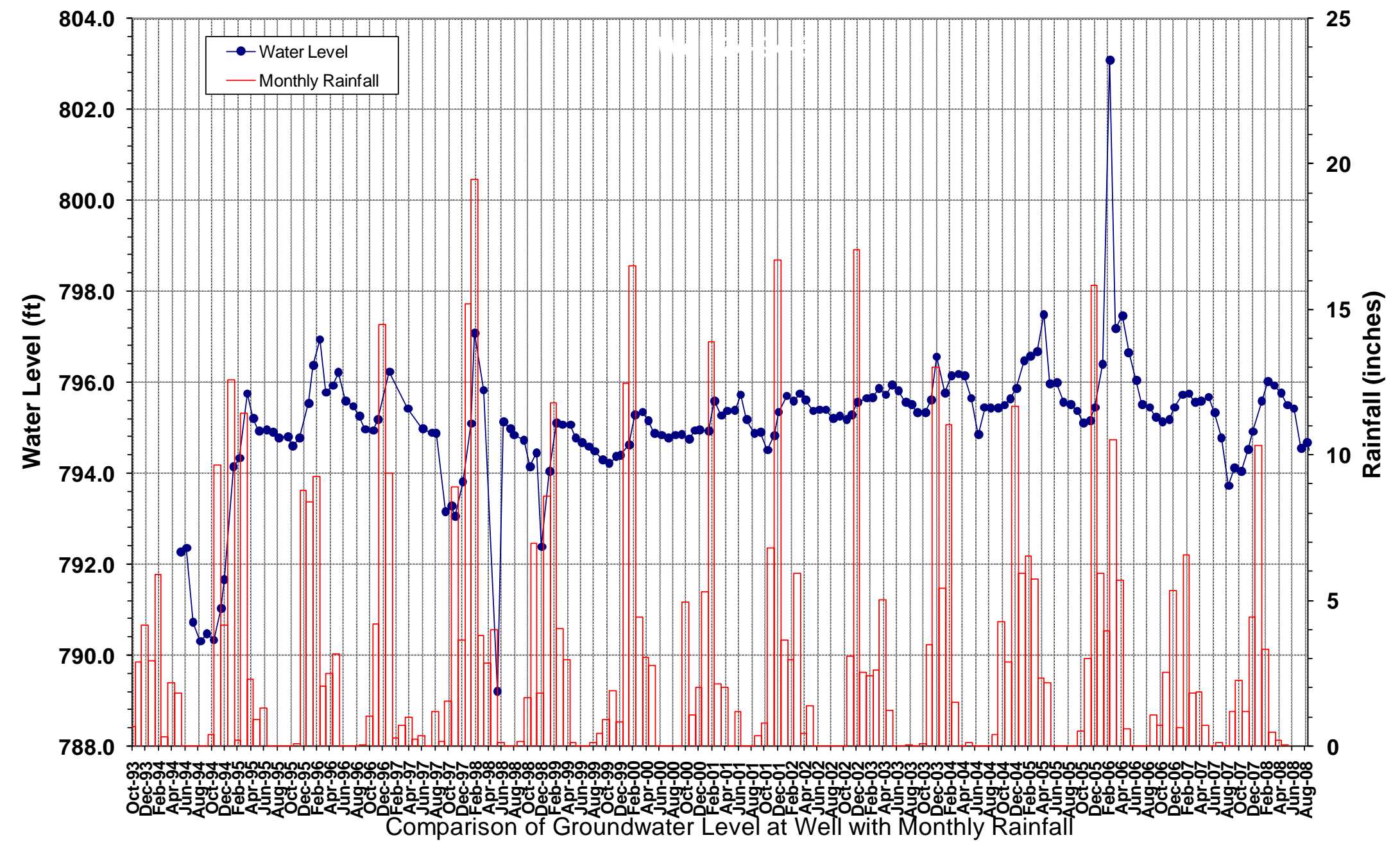

Figure 3-22. Rainfall data and water level in MW74-94-8. (fromLBNL 2008) 


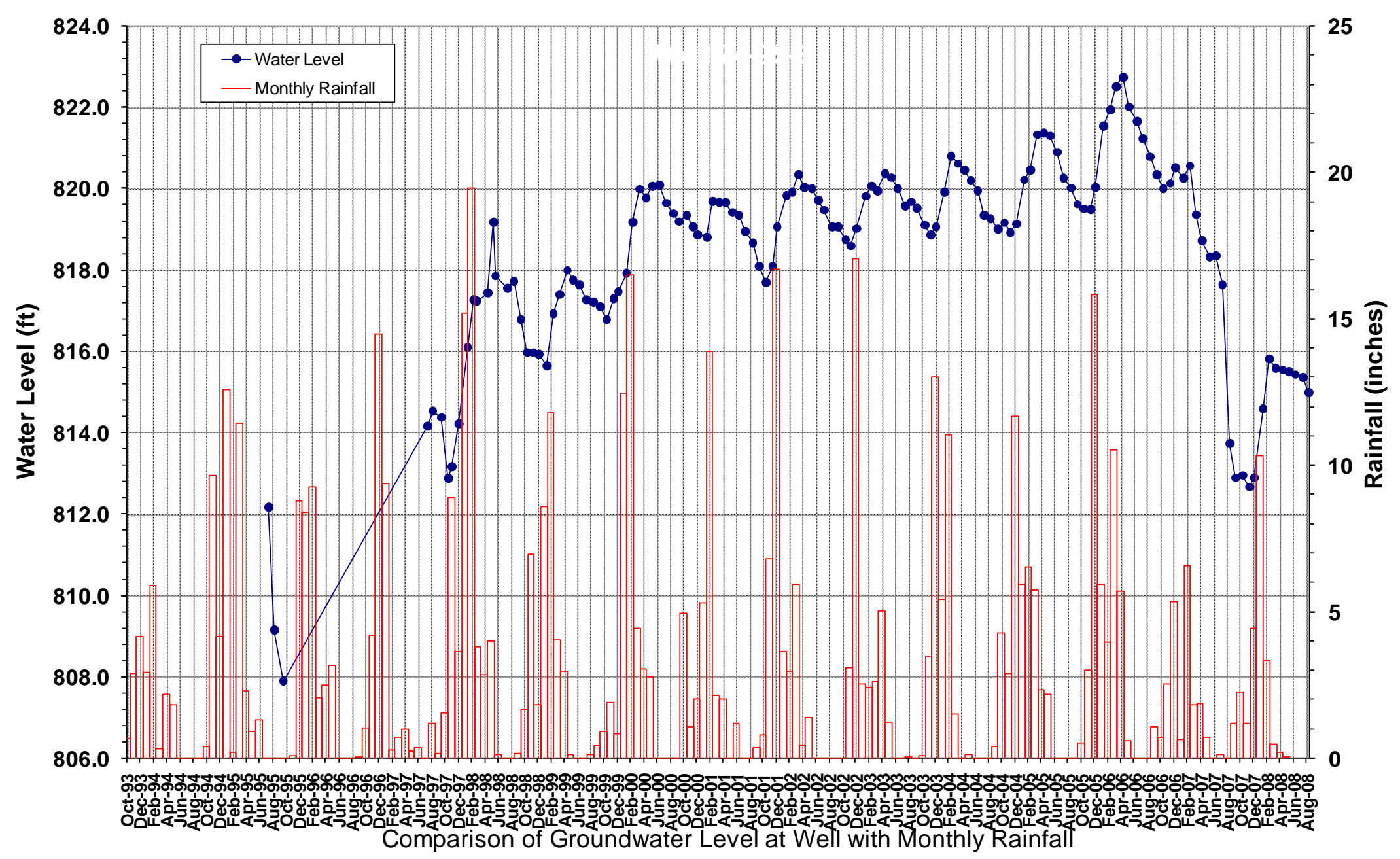

Figure 3-23. Rainfall data and water level in MW74-95-6. (from LBNL-2008) 


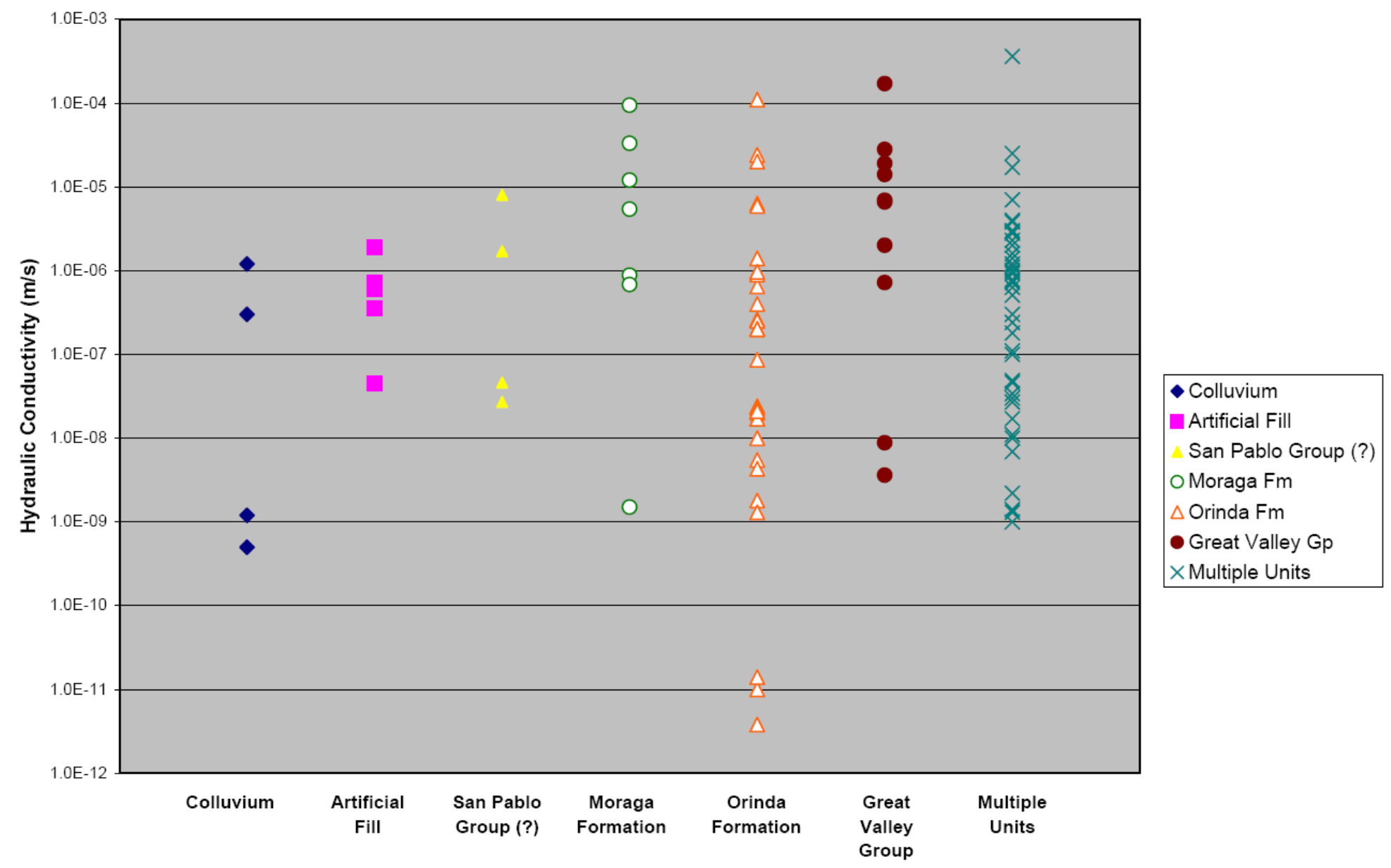

Figure 3-24. Permeability of various geologic units measured by pump tests and slug tests at LBNL (LBNL, 2000). 


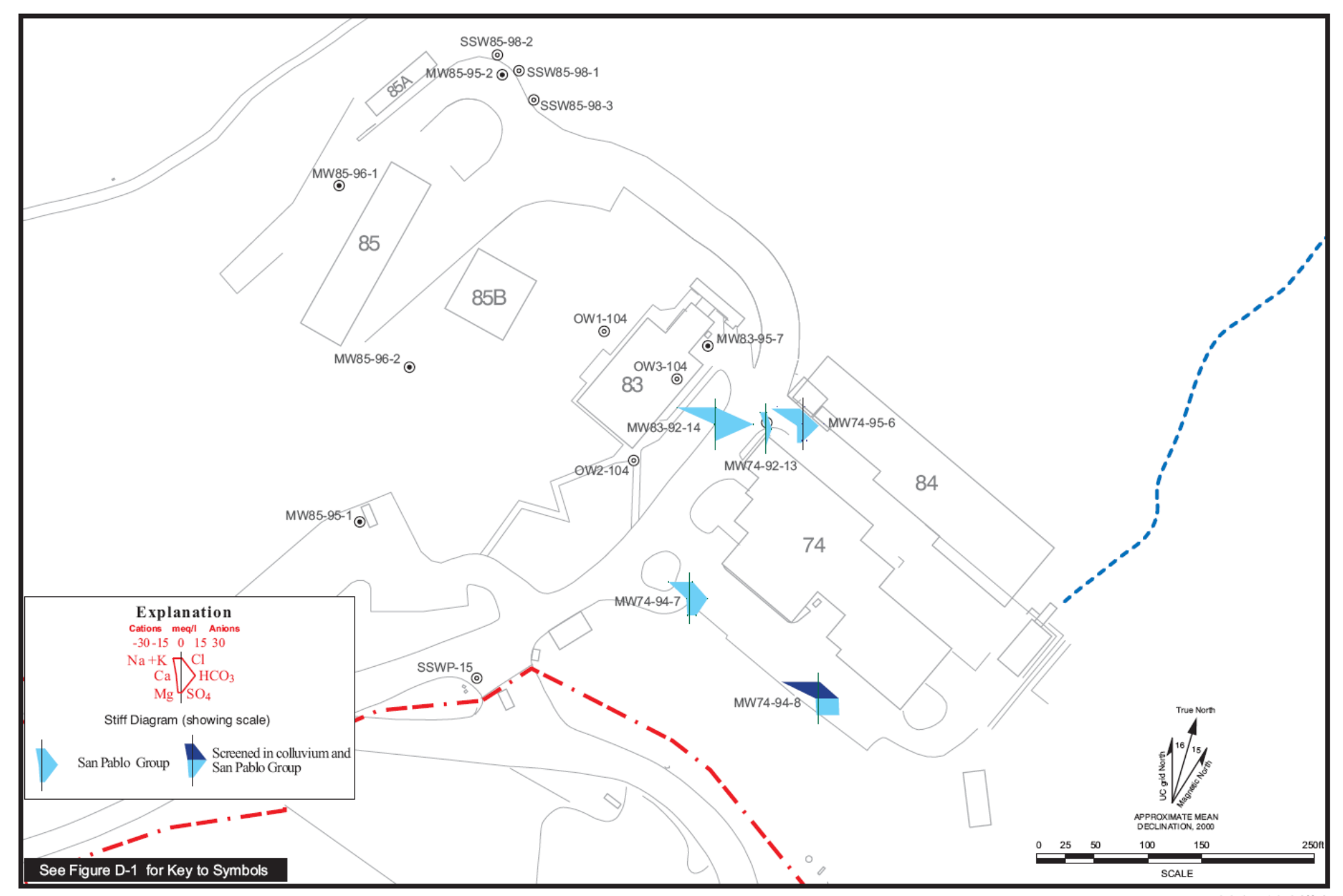

Figure 3-25. Stiff diagrams of geochemical compositions in the monitoring wells near Bldg 74. (LBNL, 2000) 


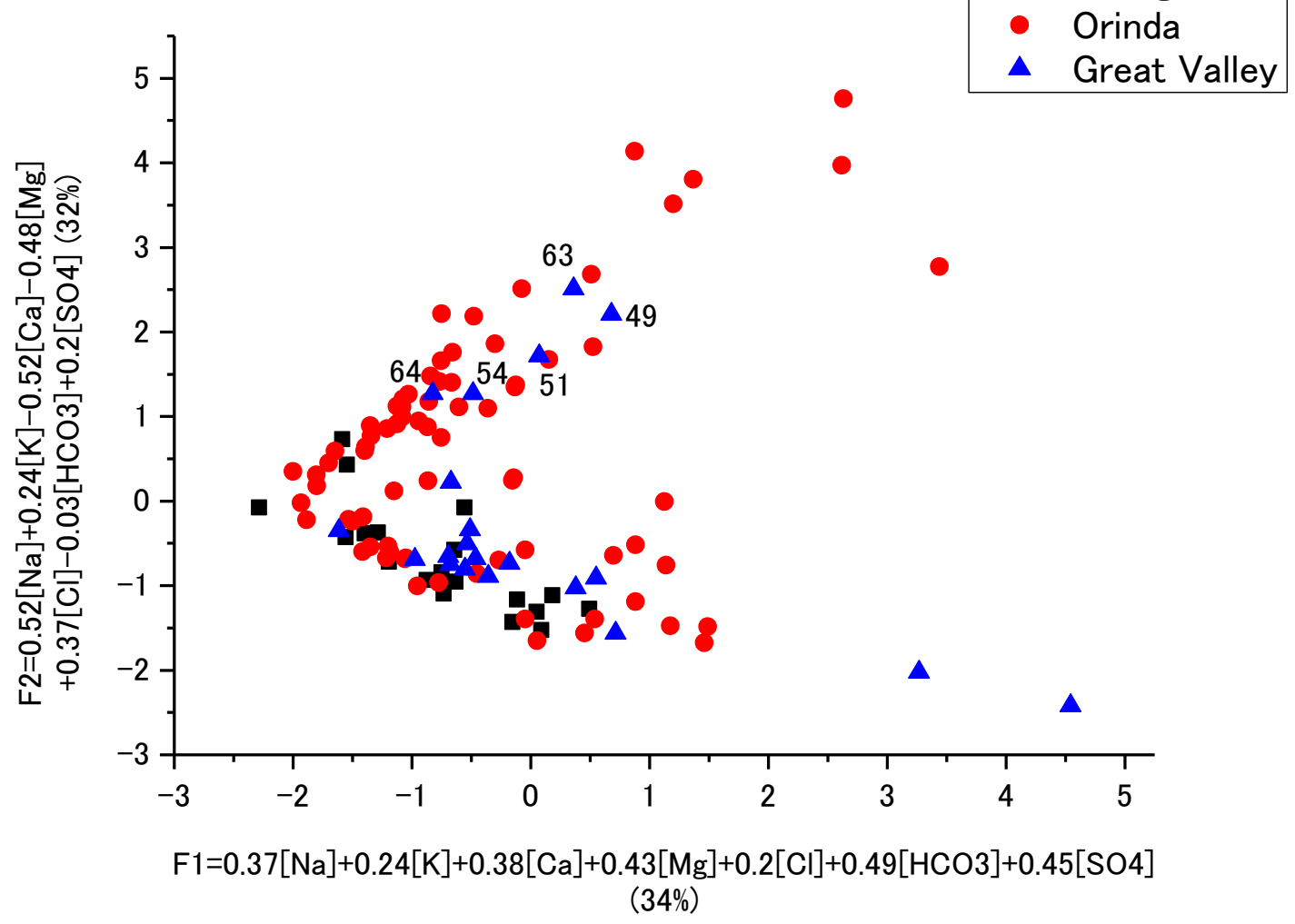

Figure 3-26 Principal component analysis of major dissolved ions. (Kiho, et al., 2009) 


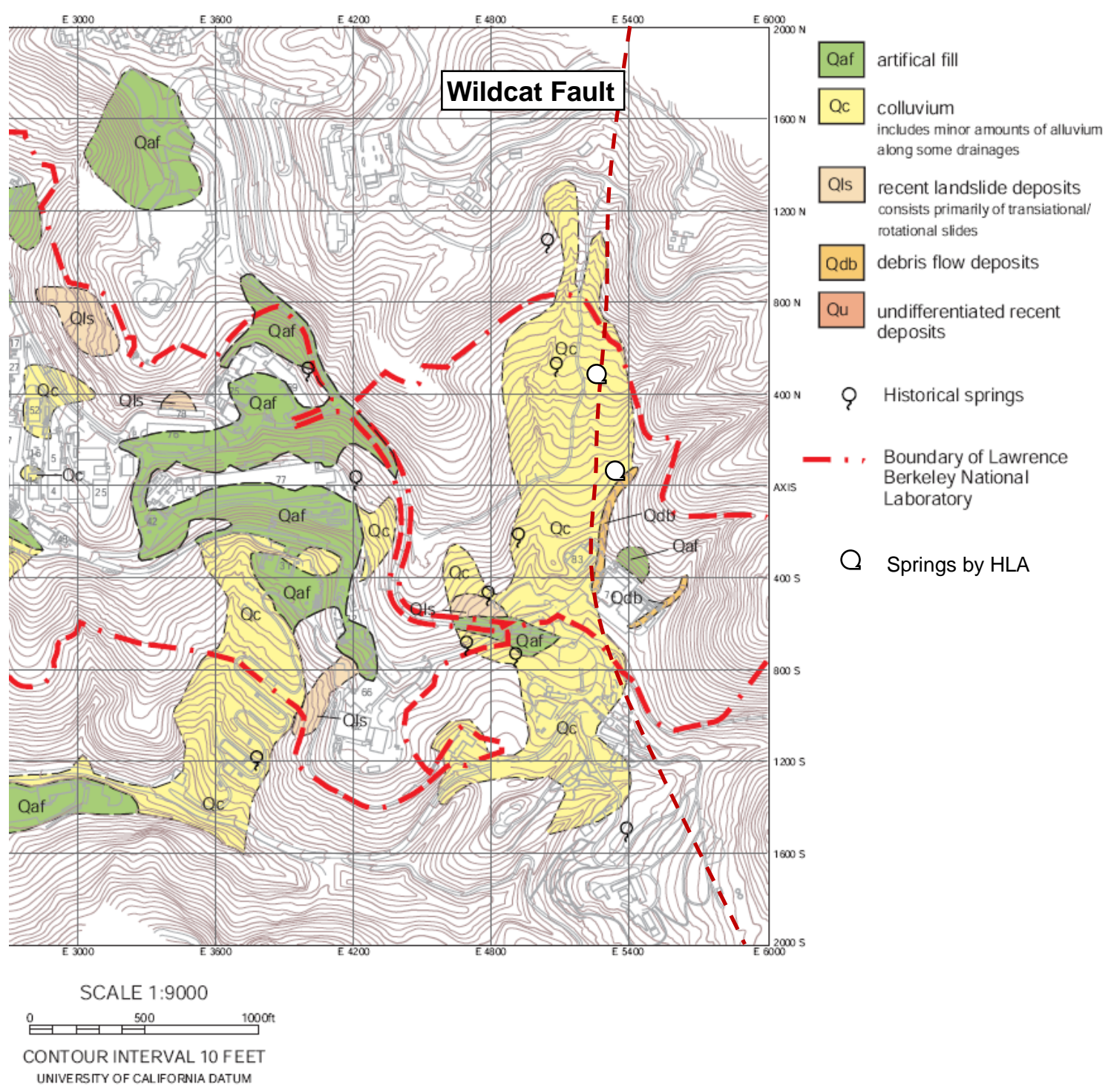

Figure 3-27. Historical springs near the Wildcat Fault. 


\subsection{Surface Investigation Plan}

本項では Wildcat 断層を対象にして行った地表踏査、物理探査、及びトレンチ調査の手 法や場所の選定の経緯について簡単に述べる。概要調査においてはスケジュールに余裕が あれば、文献調查、空中写真解析結果から物理探査の位置を決定し、物理探查の結果に基 づいて詳しい地表踏査を行う範囲を選定し、地表踏査の結果を反映してトレンチを掘削す る場所を決定できれば理想的である。本研究においては、第 3.1.1 項で述べた空中写真判 読の結果から LBNL の敷地の南部と北部で断層の性状が異なる可能性があることが判明 したことから、少なくとも LBNLの南部と北部の 2 箇所で物理探査とトレンチ調査を行う 計画を立てた。一般に物理探查で断層のおおまかな位置や性状を推定することが可能であ るが、活断層でない限り地表堆積物が断層のトレースを覆っている場合が多く、断層を横 切る事を狙ったトレンチの正確な位置を決定する根拠とはなりにくい。地表踏査に関して も同様で、断層のある基盤岩が路頭していない限り、地表踏查から断層の正確な位置を決 定する事は難しい。Wildcat 断層の場合は、具体的な物理探査の測線の位置やトレンチの 場所に関して、既存の情報や文献調查から断層のほぼ正確な位置が把握できていた。さら に、本研究においては時間の制約の理由から物理探査とトレンチ調査は同時進行的に行っ た。

\subsubsection{Geophysical Investigation Plan}

物理探查においては、時間と予算が許せば 3 次元の測定（地表面に 2 次元的にセンサー を展開）、さらには 4 次元のタイムラプス（経時変化）の計測をするのが理想的であるが、 今回の調査では 2 次元（地表面では直線上にセンサーを展開）計測を行う計画を立てた。 2 次元の測定に於いて留意すべき重要な点は以下である。

・可能な限り直線上に測線を取る。

解析において平面（断面）を仮定している為である。しかしながら、地形、建物、 道路、塀などの障害物にはばまれる場合が多い。ある程度の屈曲は解析ソフトで 補正が可能である場合がある。

・＼cjkstart対象とする断層になるべく直行するように測線を取る。

断層の性状が母岩と大きく異なるほど検出し易く、直交させることにより対比が 大きくなる。

・ 電気探査の場合、金属製の塀、ガードレール、埋設管、高圧線などからなるべく 遠ざかる。

・ より深部まで調査する為にはより長い測線が必要。 
浅部からの反射と識別するには長い水平距離を必要とする為。

・ より深部まで調査する為にはより強い震源が必要

深部まで地震波エネルギーを伝えるには大きな震源が必要

・強い震源を使うには平坦な道路が必要。

強い震源は大きな器材を必要とし、大型器材を積んだトラックが移動できる為に は良好で平坦な道路が必要。

- 深度と解像度は反比例する。

周期の長い波は深部まで到達するが、反面細かい構造には感度が低い。

今回の調査では想定される断層に直交し、出来る限り長い直線の測線の場所を決定する のが困難であった。理想的には物理探査を行った後にその結果に基づいてトレンチ箇所を 決定するのが望ましく、少なくとも物理探査とトレンチ掘削を同じ箇所で行うのが両者の データを比較対比させる上で望ましいが、現実上、不可能であった。LBNL のサイト及び 周辺は地形が険しく、震源を積んだトラックはおろか、ハンマーを持った人間が移動する ことすら困難な地形と植生に阻まれる。また、MT 法は人工物、特に近くを通る Bay Area Rapid Transit (BART) と呼ばれる電車の線路からのノイズが大きすぎると䀣念された結 果、今回の調查では MT 法は行わなかった。深度およそ $1000 \mathrm{~m}$ までの解像度を狙った場 合、有効と考えられる周波数は BART の電源の $60 \mathrm{~Hz}$ の周波数帯に近い為である。

前出のようにWildcat 断層の性状が LBNL の北と南で異なっている可能性があること から、北と南の両方で物理探査を行うこととした。上記の条件および、実際的な制約を満 たした Figure 3-33〜Figure 3-35 に示す 3 つの測線を選んだ。南の測線 2 は Graymer (2000)による Wildcat 断層を中間点としているが、さらに 3 本目の測線を西側に選んだ。 その理由は、地表踏查中に Claremont 層とSan Pablo 層と考えられる地層のコンタクト が観測されたからである。3 本目の測線はちょうどそのコンタクトが中間点になるような 測線である。

\subsubsection{Geological Investigation Plan}

LBNL の敷地内および周辺で Wildcat 断層や基盤岩が露頭しているであろうと思われる 箇所を重点的に踏査する計画を立てた。具体的には Figure 3-29 に示す Ridge Rd、、Fire Trail と Grizzly Peak Blvd.の道路に沿った地域を踏査対象とした。地形が険しい ことと、道路付近以外は基盤岩の路頭が存在しない為である。路頭している地 
層および断層を写真撮影し、特徵を記述、GPSによりその位置を記録すること とした。

\subsubsection{Trench Investigation Plan}

物理探査と同様、LBNL の敷地の南と北において Wildcat 断層の性状が異なっている 可能性を鑑みて、北と南においてトレンチを掘削する計画を立てた。理想的には物理探査 の測線と同じ箇所にトレンチを掘削する事が望まれるが、実際的な制約から物理探査の測 線と同一箇所でもあさらに、中間部の断層が確認されている場所を 3 箇所目として選んだ。 Wildcat 断層は不活断層と考えられ、LBNL 内では地表に路頭しておらず、トレンチは地 表の堆積層を過ぎて基盤岩を少なくとも $1 \mathrm{~m}$ は掘り下げる計画であった。しかし、安全面 から深度 $4 \mathrm{~m}$ を限度とした。長さについては、長ければ長い程断層を横切る可能性が高く なるが、地面の形状、建造物、操業面、コストなどの制約があり、30m 程度の長さとした。 幅に関しては掘削機械のバスケットの幅が $1 \mathrm{~m}$ 程度であり、この幅がトレンチ内での観測 作業を容易に行う為に可能な最低限の幅と考えられる事から $1 \mathrm{~m}$ 幅とした。

空中写真判読から望ましいトレンチのおおよその箇所は選定できるが、細かい正確な位 置については、今回のサイトのように地形と人工物の制約がある場合が多く、現地踏査を 行って確定する必要がある。実際のトレンチ調査の場所の選択においては前述のように LBNL(1999)、Harding Lawson Associates (HLA、1980)、Subsurface Consultants (1994), Jordan (1997)、William Lettis and Associates (WLA, 2008) の各レポートの既 存の情報から Wildcat 断層のほぼ正確な位置が事前に把握できていたことから、重機のア クセス、被りの厚さ、トレンチ観察作業の安全性、通行人の安全性などの実際的な制約と 技術的な点を総合的に考慮して最終的には 3 箇所選定した（Figure 3-28）。NUMO-TR1 と名付けた南のトレンチは WLA のトレンチの 40m 程度南側である。Graymer(2000)に よれば Wildcat 断層はこの辺りから東に湾曲しているとされている為、僅かに東寄りを選 んだ。北の NUMO-TR2 は HLA の Trench A の 20m 程度南に選定した。NUMO-TR3 は前述の Calvin Rd.を造成する際に斜面の切り取り工事の際に Jordan (2008)によって確 認された断層の箇所を選んだ。

\subsubsection{Geochemical Investigation Plan}

地下水の地化学的調査はスケジュールとコストの観点から本年度は執り行わないこと 
とした。技術面から鑑みても、既存のボアホールからの地下水のサンプル取得は何時でも 容易に可能である事、それらの主要イオンについては既存データが存在する事、肝心の Wildcat 断層の近傍には既存のボアホールが存在せず、次年度でのボアホール掘削を待つ 必要がある事が挙げられる。 


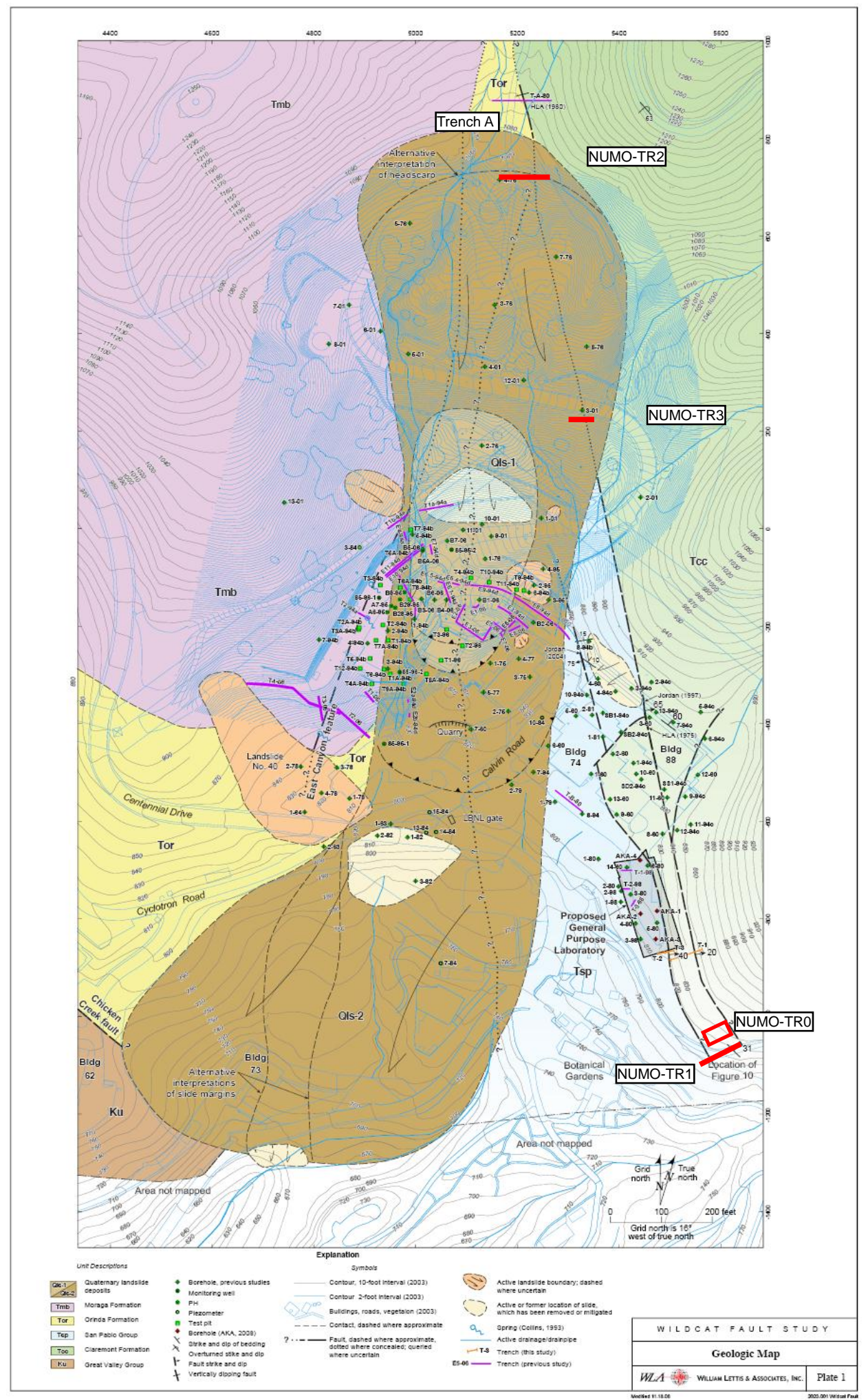

Figure 3-28 WLA and NUMO trench locations (Modified from William Lettis Associates, 2008) 


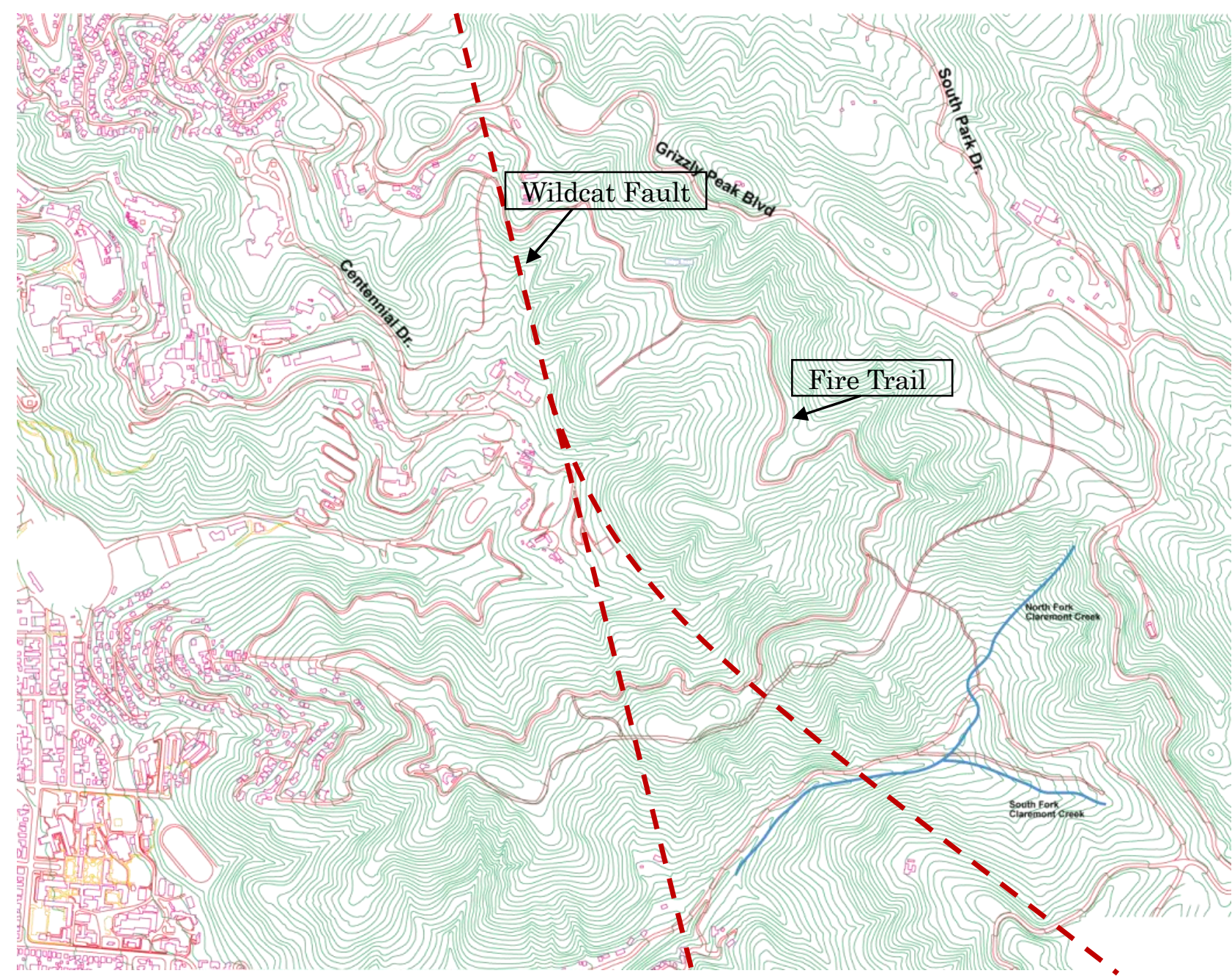

Figure 3-29 Contour map around the LBNL property and the Fire Trail. 


\subsection{Surface Investigations}

\subsubsection{Geophysical surveys}

\subsubsection{Introduction}

物理探查は地表から地下の性状を探る有効な手法である。概要調查においては、通常文 献調查の次のステップとして行われる。物理探查の情報に基づいて断層の位置を推定し、 それに基づいて詳しい地表踏査やトレンチの箇所を選定し掘削、観察が行われる。しかし ながら、実際に物理探査と地表調查のどちらが先に行われるかは状況次第である。今回の Wildcat 断層の調査においては、断層の位置がすでに過去の調査からかなりの精度で既知 であった事、物理探査と地質調査のスケジュールの都合により、物理探査とトレンチ調査 はほぼ平行して行われた。実際、物理探查の現地調查が終了したのはトレンチ調查の後で あった。

物理探査は万能ではなく、どこで物理探査を行うかは地質調査のデータが役立つ。無論 調查対象地域全域にわたって 3 次元、さらには 4 次元の物理探查を行えれば理想的である が、コストが嵩む上、全域にわたってセンサーを展開することは実際上難しい。一般には 限定された箘所で限られた数の測線上で物理探查を行うことになる。その場合は事前の地 表調查が欠かせない。今回の物理探查も前もって地表を踏査した上で測線の場所を決定し た。本セクションでは電気探查と反射法地震波探查の結果についてまとめる。実際の調查 は Norcal Geophysics 社（Black, 2009）によって行われた。

\subsubsection{Survey Lines}

前節でも述べたが、断層を対象とした測線は断層に直行する方向で可能な限り一直線に 長い測線を取るのが望ましい。しかし、往々にして地形や構造物などの制約がある。本プ ロジェクトも例外ではなく、Wildcat 断層が走る LBNL 付近の地形は険しく震源を搭載 した車両のアクセス可能か否かが測線の場所を決定する重要なファクターとなった。

Figure 3-33、Figure 3-34Figure 3-35 に詳しい測線の位置を示寸。図に示寸ように測線 1 は Field Station for Behavioral Research (FSBR) と呼ばれる UC Berkeley の研究施設 内の南西から北東に走る狭い道路の西側に沿って長さ $330 \mathrm{~m}$ でほぼ直線に取った。測線 2 と 3 は図に示すように、LBNL の南のバークレー丘陵の稜線上を南西から北東に走る Panoramic Rd. または Ridge Rd. と呼ばれる山火事時の緊急自動車専用道路を使用し 
た。これらの測線は測線 1 から約 $1500 \mathrm{~m}$ の南の距離に位置する。測線 2 は長さ約 $340 \mathrm{~m}$ で Graymer (2000)による Wildcat 断層が中間点となるように設定し、測線 3 は長さ約 250m で地表踏査で確認された Claremont 層と砂岩（San Pablo 層?）のコンタクトを中 間点として設定した。

\subsubsection{Electrical Resistivity Survey}

電気比抵抗は dipole-dipole array を使い、測線 1 と 2 は $6 \mathrm{~m}$ おきに合計で 56 機 の電極を全長 $336 \mathrm{~m}$ に渡って展開した。測線 3 では $252 \mathrm{~m}$ の長さに $4.5 \mathrm{~m}$ おきに 56 機 を配置した。データの取得には Advanced Geosciences 社の SuperSting R1 と呼ばれる比抵 抗測定装置と Swift と呼ばれる自動複数電極システムを組み合わせて使用した。

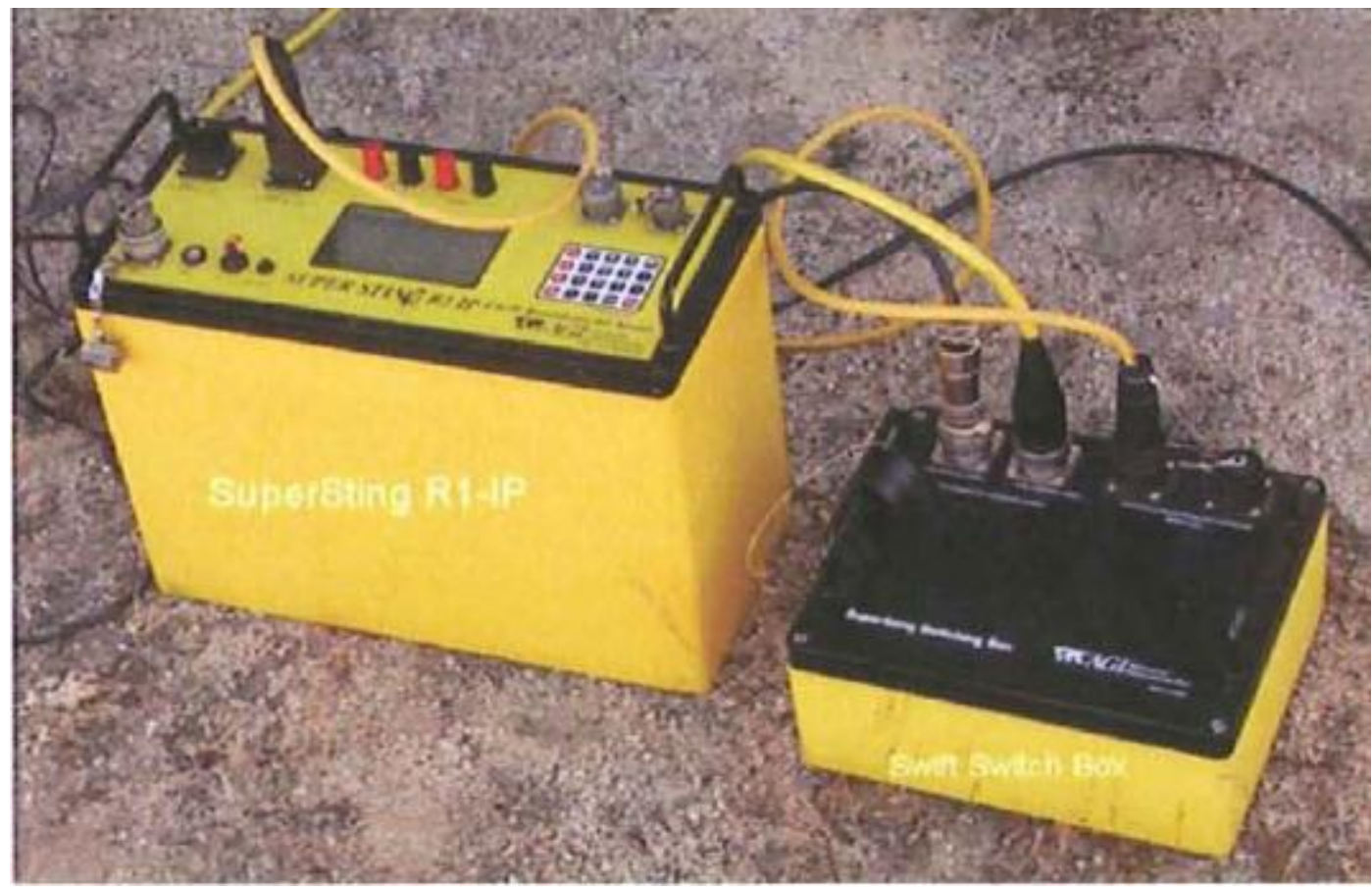

Figure 3-30. Supersting and Swift data acquisition system by AGI.

Supersting は単体で 1 900mA の間で出力が調節可能であり、電圧降下を見かけの比 抵抗に換算する機能がある。Swift は最大 $10 \mathrm{~m}$ 間隔で 1 本につき 14 機の電極をつないだ 4 本のケーブルを接続可能で、最大 56 機のステンレス製の電極の測定が可能である。電 極を動かさずに 1 回の測定に付き 4 つの電極を選ぶことにより Dipole-dipole 法の測定が 可能となる。選ぶ 4 つ電極の間隔を変えることによって測定深度を変化できる利点がある。 
測定データの再現性を保証する為に最低2回は繰り返して計測を行うように設定されてい る。取得データは内臓メモリーに記録され、後にパソコンにダウンロードして解析を行う。 データ解析は AGI 社の EarthImager と呼ばれる逆解析ソフトを使用した。同一測定区間 で再現性に 5\% 以上の誤差があればそのデータは使用しない設定とした。EarthImager は 中途の逆解析結果をグラフ状にディスプレーする事が可能で、測定データが計算結果と一 致するまでノイズの多いデータやシグナルが弱い測点を除きながら繰り返し解析を行っ た。

最終解析結果は深度対距離の 2 次元垂直断面に比抵抗の分布として求まり、Surfer と呼 ばれる可視化プログラムを使用してコンターマップで表した（Figure 3-36）。図に見られ るように比抵抗は 10 1000 Ohm-m の間で分布している。すべての測線において深度 $15 \mathrm{~m}$ 〜 50m ではばらつきが著しい。それ以上の深度では比抵抗のばらつきが減少傾向にある。 これらの事から、深度 $50 \mathrm{~m}$ までは風化の進んだ亀裂の多い岩盤であり、それ以深ではあま り風化されておらず、亀裂も少ないと考えられる。

側線 1 と 3 は青色や緑色で示される比較的低い比抵抗を示すが、測線 2 では黄色やオレ ンジ色で表される比抵抗の高いゾーンが東に向かって深度方向に伸びており、およそ $2 / 3$ の地点で消滅している。これは測線 1 や 3 の地下にある岩盤とは違った種類の岩盤である 可能性が高い。測線 2 で見られる水平方向の急激な比抵抗の変化は断層の影響として解釈 することが出来る。測線 1 や 3 でも垂直方向に低い比抵抗の分布や不連続性から断層が存 在すると思われる箇所を図に赤い破線で示した。

\subsubsection{Seismic Reflection Survey}

反射法地震探査の計測には Geometrics 社の Geode と呼ばれる 96 チャンネルの震探シ ステムと 96 機の固有振動数が $40 \mathrm{~Hz}$ の Mark Products の受振機（Geophone）を使用した (Figure 3-31)。測線 1 と 2 では geophone の間隔を $3 \mathrm{~m}$ とし、3m×(96-1)で全長 $285 \mathrm{~m}$ の配 列とした。測線 3 は 72 個の geophone を使用し、全長 $213 \mathrm{~m}$ であった。いずれの測線も予 想されているWildcat 断層のトレースを中間点として展開した。震源はそれぞれの測線の 端の受振機の $1.5 \mathrm{~m}$ 外側から開始し、 $3 \mathrm{~m}$ おきに発振した。結果、測線 1 は 96 地点で発震、 測線 2 は 97 地点、測線 3 は 73 点の発震点となった。殁どの地点において震源は ATV(All Terrain Vehicle、全地形万能車)に搭載した accelerated weight drop と呼ばれる震源を使用し た。ATVでもアクセス不能であった測線 1 の東端ではハンマーとプレートを使用した。 


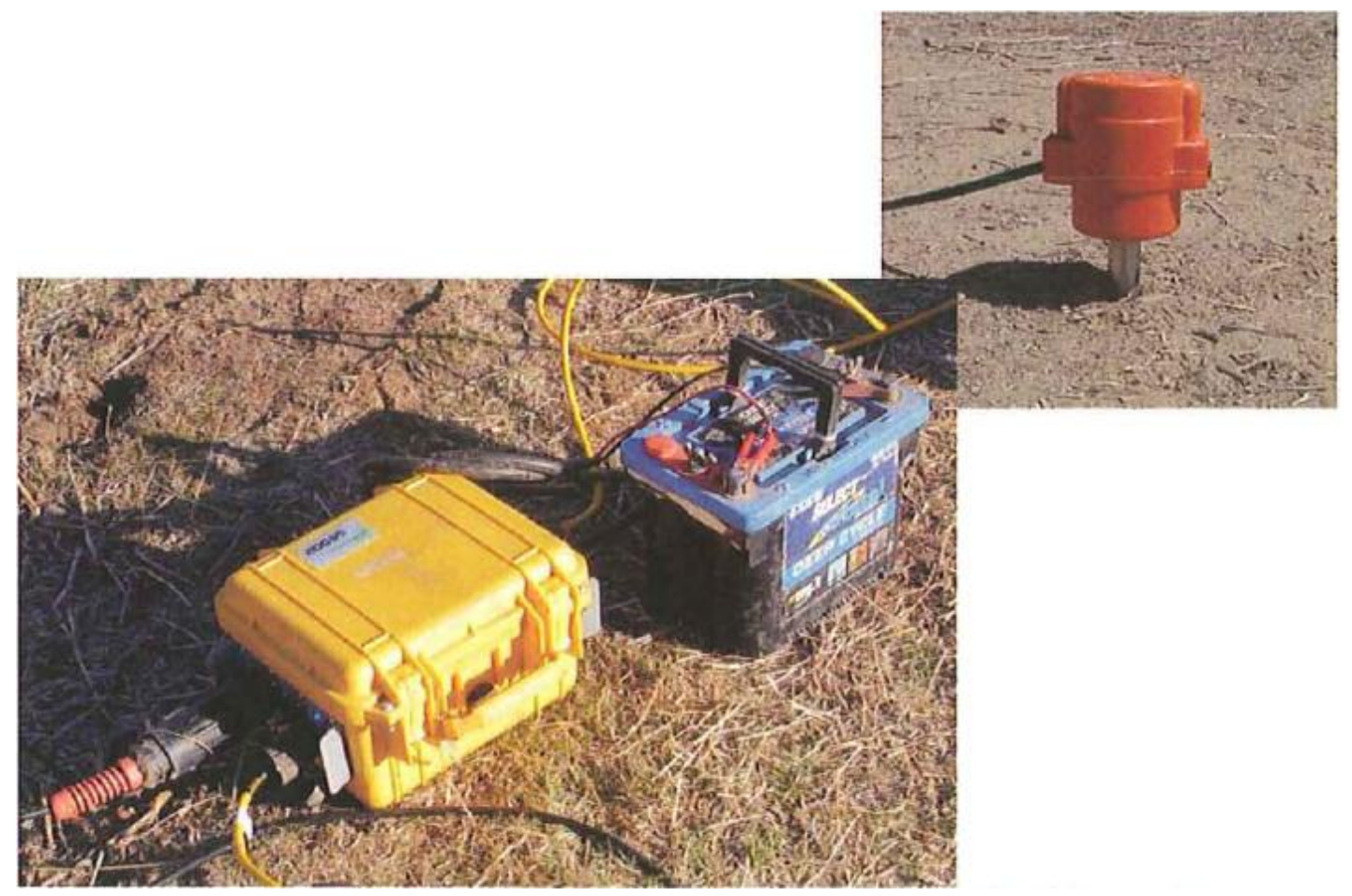

Figure 3-31. Geode seismic system (left, yellow) and 40Hz geophone by Mark Products (right, orange) (Norcal Geophysics, 2009)

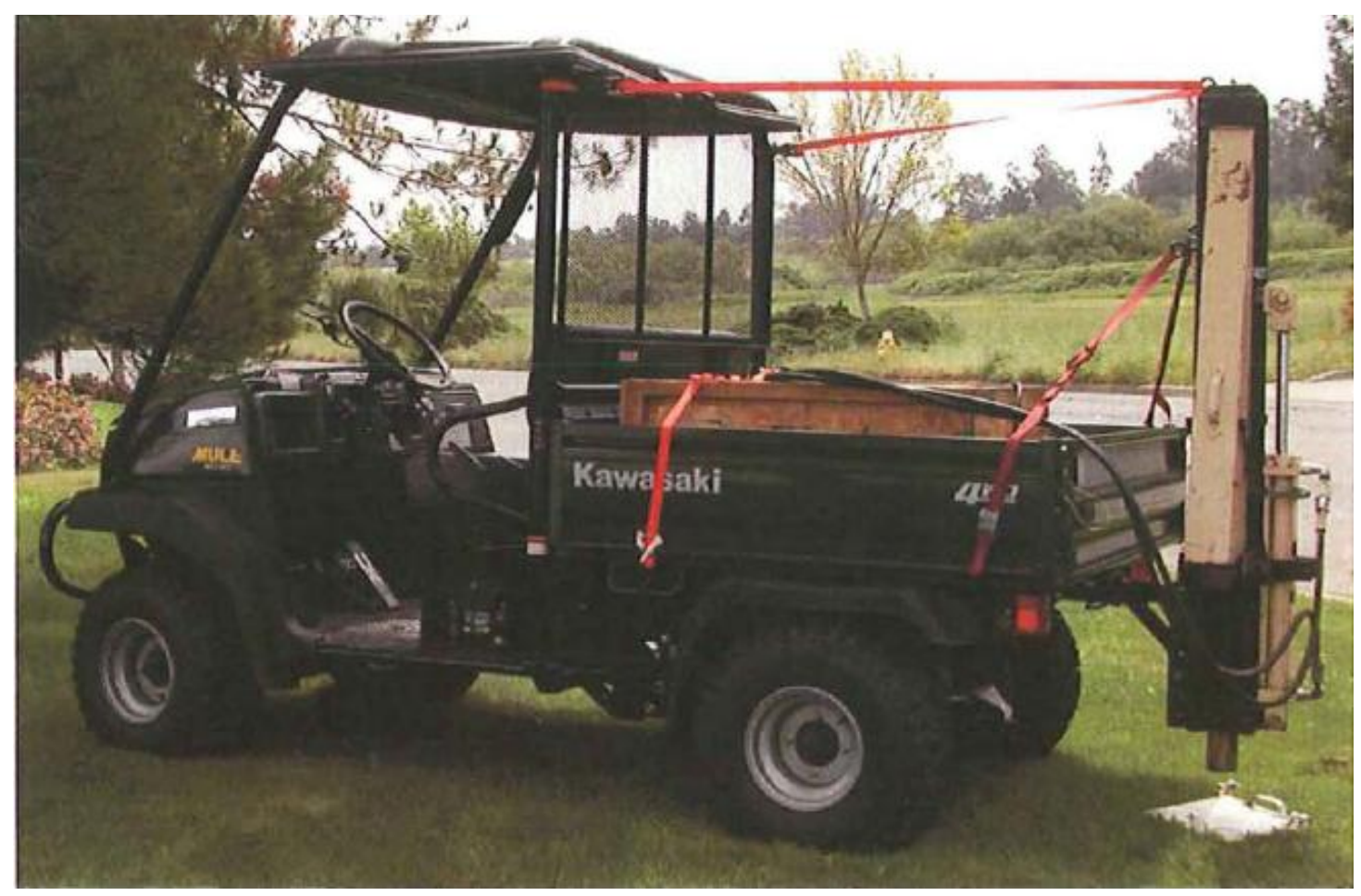

Figure 3-32. Accelerated weight drop system mounted on an ATV (Black, 2009). 
反射法の解析は主として Advanced Geosciences 社の Mark Olson による。解析には Gedco 社の Vista 8.0 2D/3D と呼ばれるソフトを使用した。最終的な重合結果を得るまで の基本的な解析手順や設計概念は石油やガスの探査の震探データの解析手法と同様であ る。以下解析手順を列挙する。

1. Trace editing

2. Geometry definition

3. 2D crooked line common-midpoint (CMP) binning

4. Trace muting of first arrivals

5. FK (time-space frequency) filtering to attenuate ground roll

6. Bandpass filtering 50/60 - 180/200 Hertz

7. Automatic gain control (AGC) using $80 \mathrm{~ms}$ windows

8. Static shift to horizontal datum elevations

9. Trial velocity analyses using semblance and common-offset stacks

10. Trial CMP (Common Mid Point) stacks

11. Final velocity analysis

12. Final CMP stack

13. Trace mixing using weighted average 01 three traces

14. Bandpass filtering 40/50 - 150/180 Hertz

15. AGC using 60 to $80 \mathrm{~ms}$ windows for final display

Figure 3-37Figure 3-38、Figure 3-39 にそれぞれ測線 1、2、および3 の静補正を施し た重合断面図を示す。マイグレーションアパチャーが広く、データの品質のばらつきが大 きく、CMP フォールドの水平方向の変化がある為、重合後の時間マイグレーションは行 っていない。地表面の簡単な標高補正は測線 1 を標高 $430 \mathrm{~m}$ 、測線 2 と 3 を標高 $390 \mathrm{~m}$ を基 準として静補正を行っている。CMP は 1.5m 間隔であり、Figure 3-35 に共通中間点重合 
（CMP Stacking）の地点番号を示す。Figure 3-37、Figure 3-38、及び Figure 3-39 の縦軸 は往復走時であり、深度に比例するが、深度の絶対值を決定する為には各地層の $\mathrm{P}$ 波速度 が必要である。一般に $\mathrm{P}$ 波速度はボアホールを掘削して計測するが、現時点ではデータが 存在しない。その為、比抵抗解析結果と総合して P 波速度を推定した。具体的には比抵抗 が概ね一定になる深度と最も浅い $\mathrm{P}$ 波の反射面を同一深度として重站合わせた（Figure 3-40 及び Figure 3-41）。その結果、風化していない基盤岩表面は標高 $256 \mathrm{~m}$ 付近であると 推定される。これは往復走時にして $400 \mathrm{msec}$ となり、P 波速度では $1280 \mathrm{~m} / \mathrm{s}$ となる。この 速度は比抵抗探査の到達深度である $50 \mathrm{~m} 75 \mathrm{~m}$ の深度では妥当であると考えられる。ただ し、より深度が深くなるにつれて速度が早くなると考えられるので $75 \mathrm{~m}$ 以深の反射面は図 に示す深度より、深い深度である可能性があると考えられる。

Figure 3-37Figure 3-38Figure 3-39 および Figure 3-40、Figure 3-41 に反射波と比抵抗の 総合解析から推定される反射ホライゾン A、B、C をそれぞれ緑色、紫色、青色の線で示 す。これらの層は地質図からも推定されるそれぞれ異なった堆積地層の反射面であると考 えられる。ホライゾン A は識別を容易にする為に Figure 3-40 及び Figure 3-41 では黄色、 茶色の線で表す。測線 1 の反射断面図の Figure 3-37 にCMP73 地点の直下のホライゾン A の上下方向の顕著なオフセットによると考えられるアーチ状の回折パターンを黄線で 示す。さらに、Aより深い深度の反射ホライゾン B、C も鉛直方向にオフセットしている と考えられる。これらのオフセットの位置を総合して判断すると黒の破線で示す断層が存 在すると解釈できる。この断層は東側がせり上がり、西に高角度で傾斜していると思われ る。これはHLA (1980)が行ったトレンチAの調査で確認された Wildcat 断層と考えられる 断層と性状が一致している。測線 2，3 においても、Figure 3-38Figure 3-39 に見られる ように反射ホライゾン A 及び B の存在が推定できる。さらに測線 3 では Figure 3-39 に黄 線で示すように測線 1 で見られた反射ホライゾン A の不連続性による回折パターンが確 認できる。しかしながら、測線 1 で見られた反射ホライゾンは測線 2、3 では認める事が 出来ない。上下方向のオフセットは測線 1 で見られたほど大きくないが、測線 1 で見られ たと同様、東側がせり上がっており、西に傾斜している。測線 2 で解釈される断層は傾斜 角度が測線 1 や 3 と比較してかなり浅い。これらを総合し、想定される断層を Figure 3-38Figure 3-39 に黒い破線で示す。これらを地表に外挿すると地表踏查で確認された断 層の位置とほぼ一致する。 


\subsubsection{Alternative Analysis}

Figure 3-42、Figure 3-43、及び Figure 3-44 に Rufus Catchings (2009)による解釈結果を示 す。図から明らかなように Figure 3-37Figure 3-38Figure 3-39 の解釈とはかなり異なってい る。この事から分かるように、反射断面は複数の解釈が可能である。一般にバークレー丘 陵の地層は非常に複雑であり、Claremnnt チャートは褶曲が顕著で亀裂も非常に発達して いる。また Moraga 層は火山岩であり亀裂が発達し、連続性にそしい。これらのことから 反射法地震探查に適した連続した反射面が存在しないか、存在していても地表面近くの不 均質性によりノイズが多く反射面を捉えにくいことが原因である。

\subsubsection{Summary}

以上に述べた電気比抵抗探査及び反射法地震探査の結果を以下にまとめる。

1. 西に傾斜し、東側の地層がせり上がった Wildcat 断層と推定される断層が何れの 測線でも認められた。

2. 測線 1 及び 3 で認められた断層は類似して急な傾斜であるが、測線 2 の断層は傾 斜が浅い。

3. Wildcat 断層は深部で Hayward 断層に合流している可能性がある。

4. 電気比抵抗探査あるいは反射法地震探査のみの結果の解析では不確実性が多いが 両者を組み合わせて総合的に解釈寸ることによりそれぞれの手法の結果の信頼性 が増し、Wildcat 断層の性状に関して不確実性を減らすことが可能になった。

5. 物理探査の測線の位置は既存のWildcat 断層の情報に基づいて決定したため、何 れも断層を横切っていると考えられるが、既存の情報が無い場合は断層を中心に 測線を取る事が困難である可能性がある。 


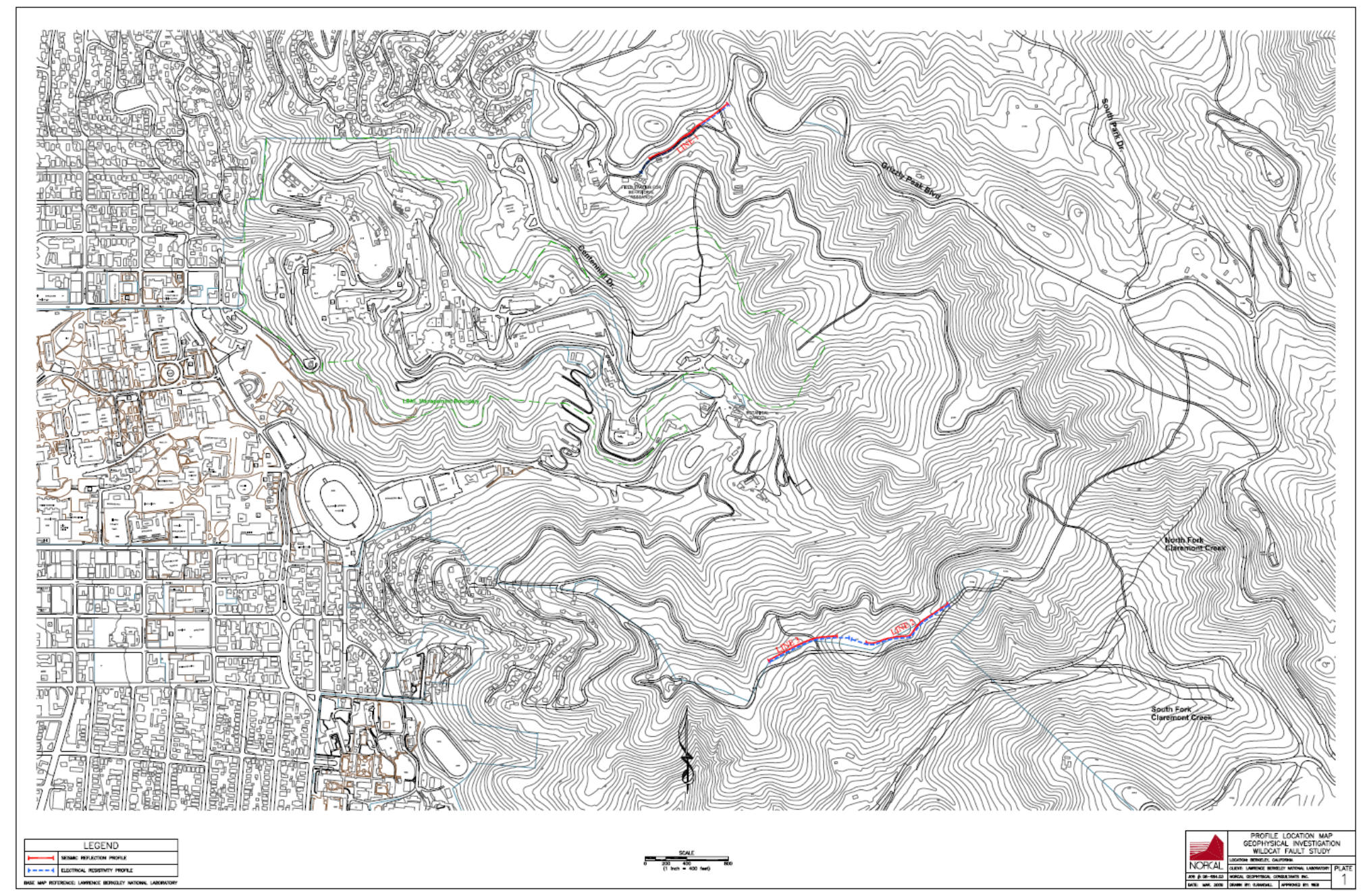

Figure 3-33. Geophysical survey lines Line 1 to the north and lines 2 and 3 to the south of LBNL property. Green broken line denotes LBNL property line. 


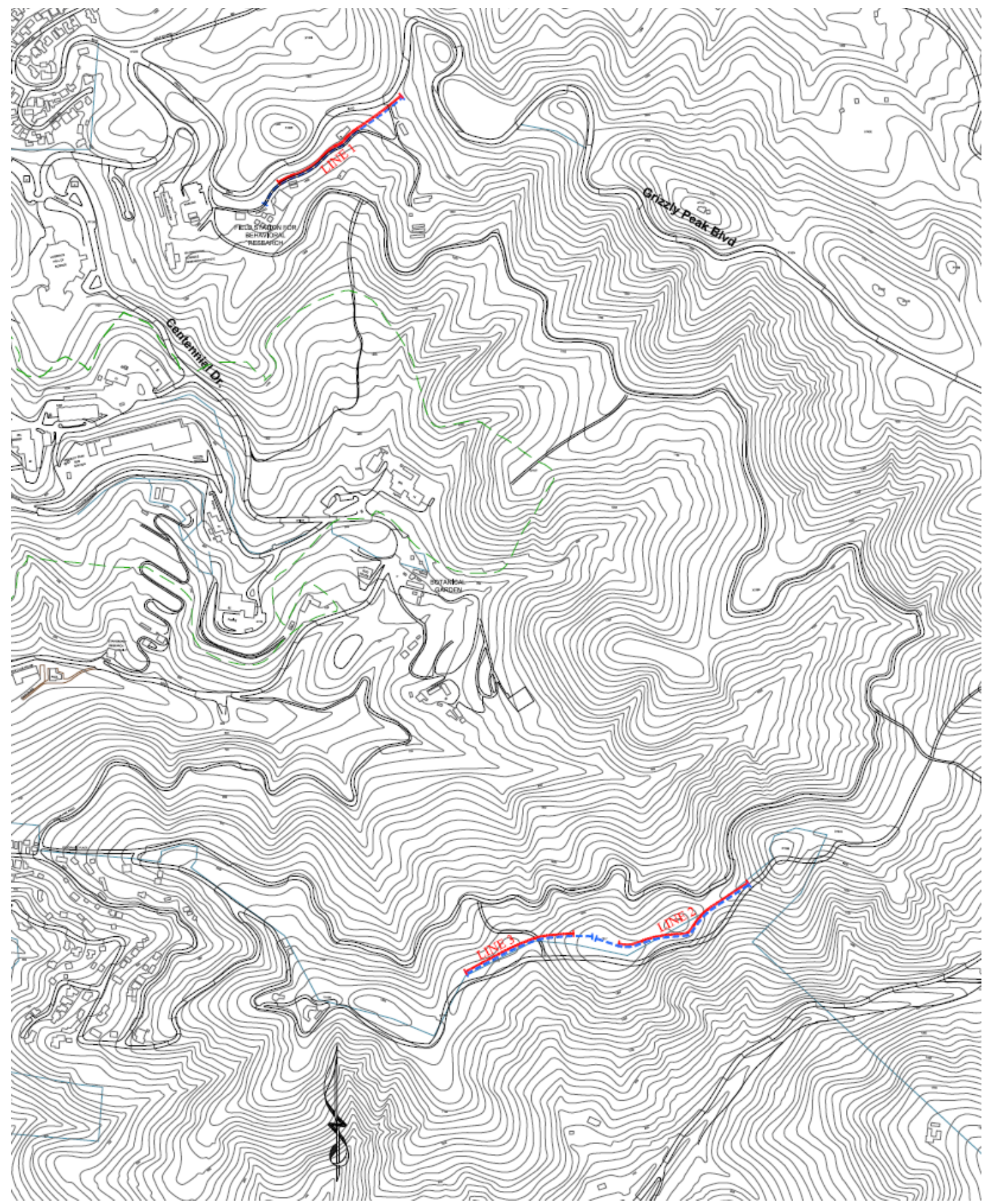

Figure 3-34. Enlarged view of Figure 3-33. Geophysical survey lines Line 1 to the north and lines 2 and 3 to the south of LBNL property.. 


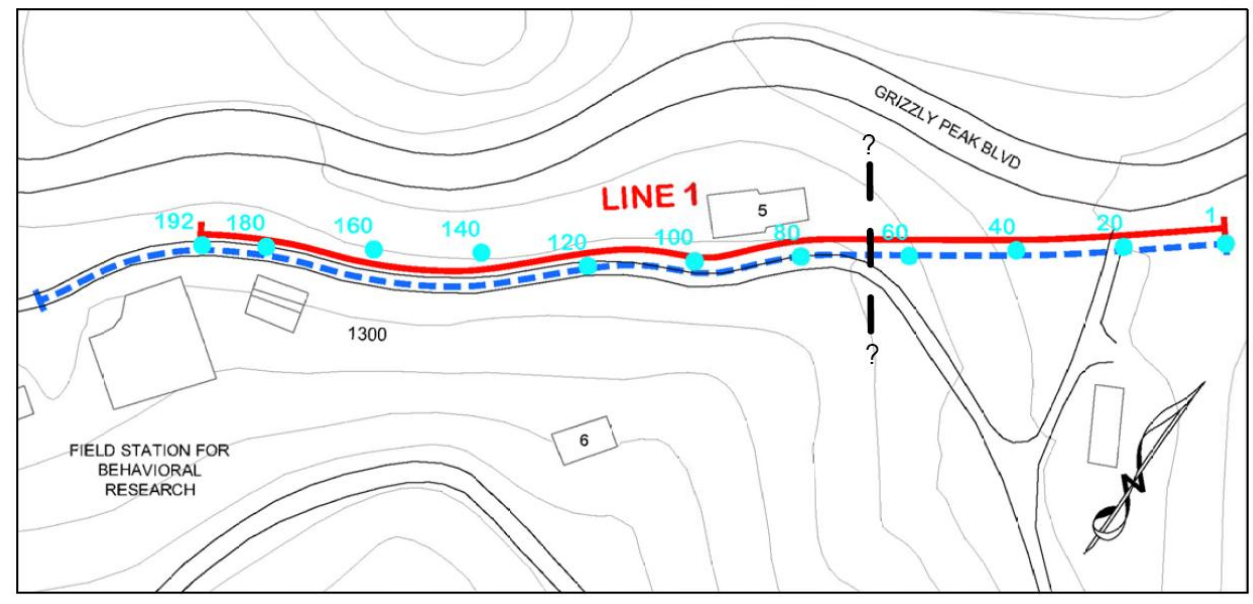

\begin{tabular}{|c|l|}
\hline \multicolumn{2}{|c|}{ LEGEND } \\
\hline$\longmapsto+1$ & SEISMIC REFLECTION PROFILE \\
\hline rーーーー & ELECTRICAL RESISTIVITY PROFILE \\
\hline 10 & CMP \\
\hline
\end{tabular}

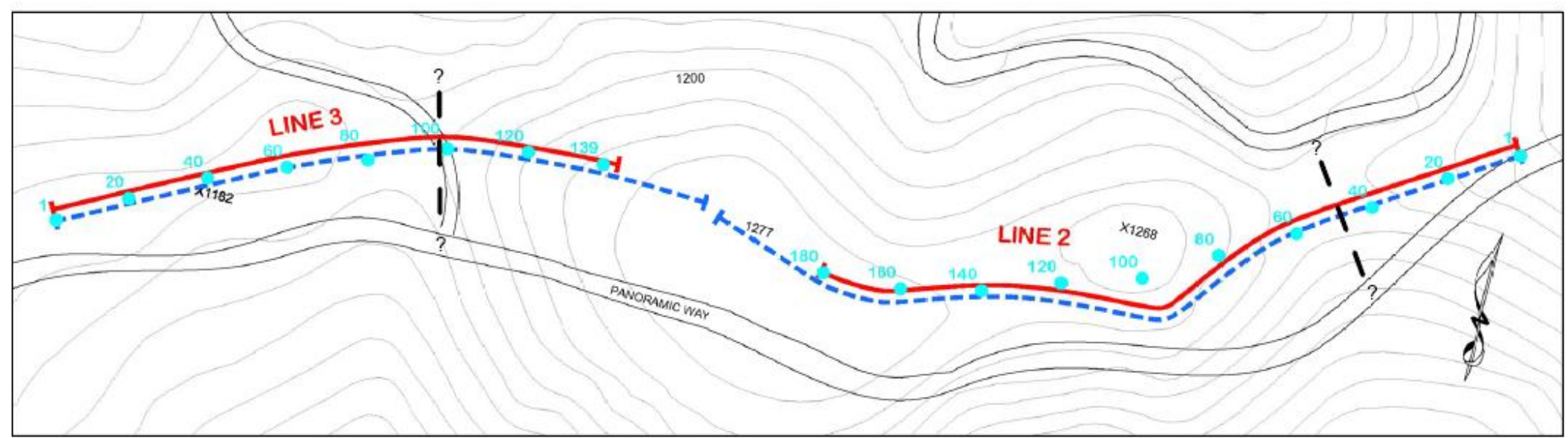

Figure 3-35. Further enlarged view of the survey lines 1, 2 and 3 for electrical resistivity and seismic reflection profiles. 

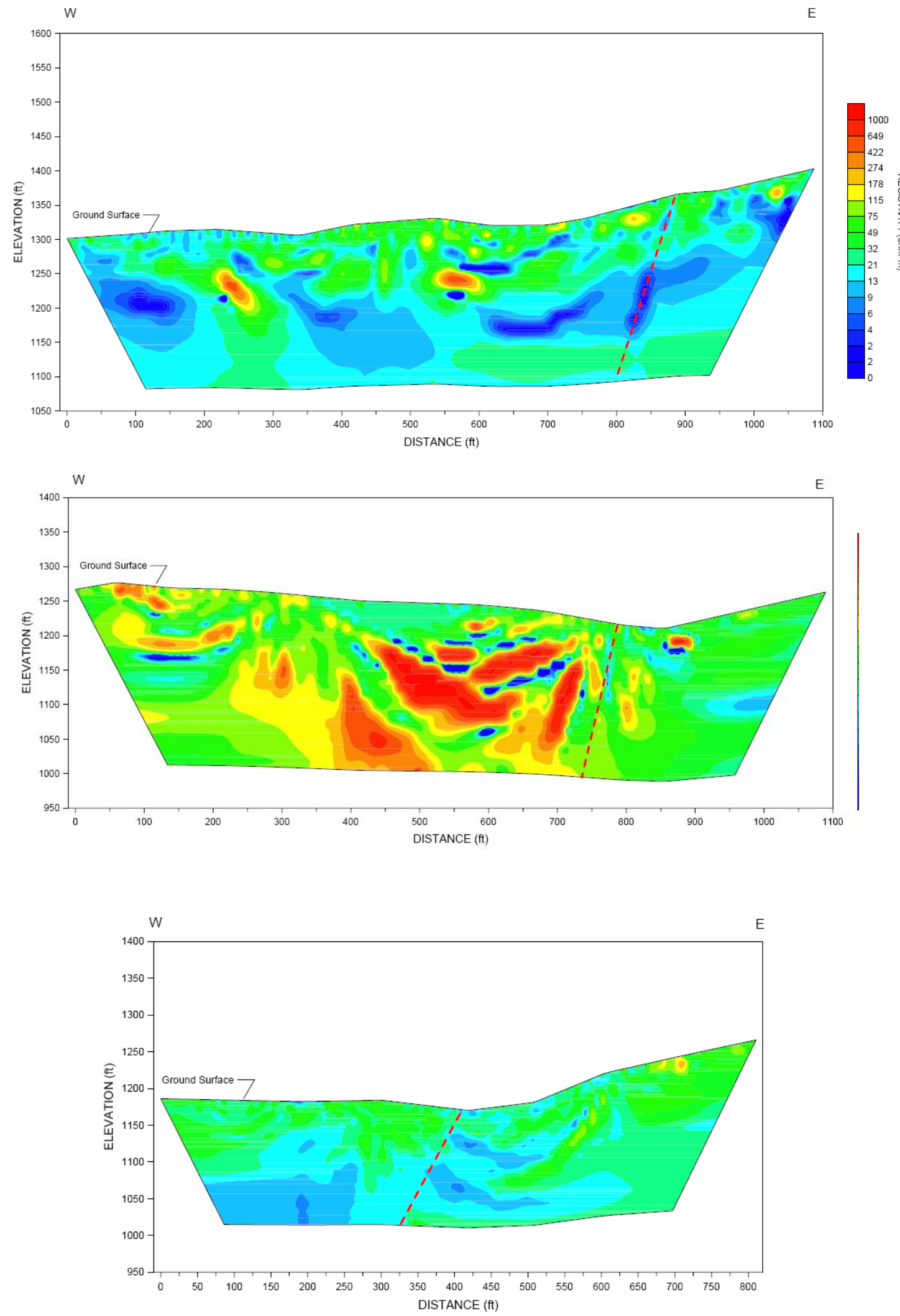

Figure 3-36. Electrical resistivity profiles for Line 1(top), 2 (middle) and 3 (bottom). 
LINE 1

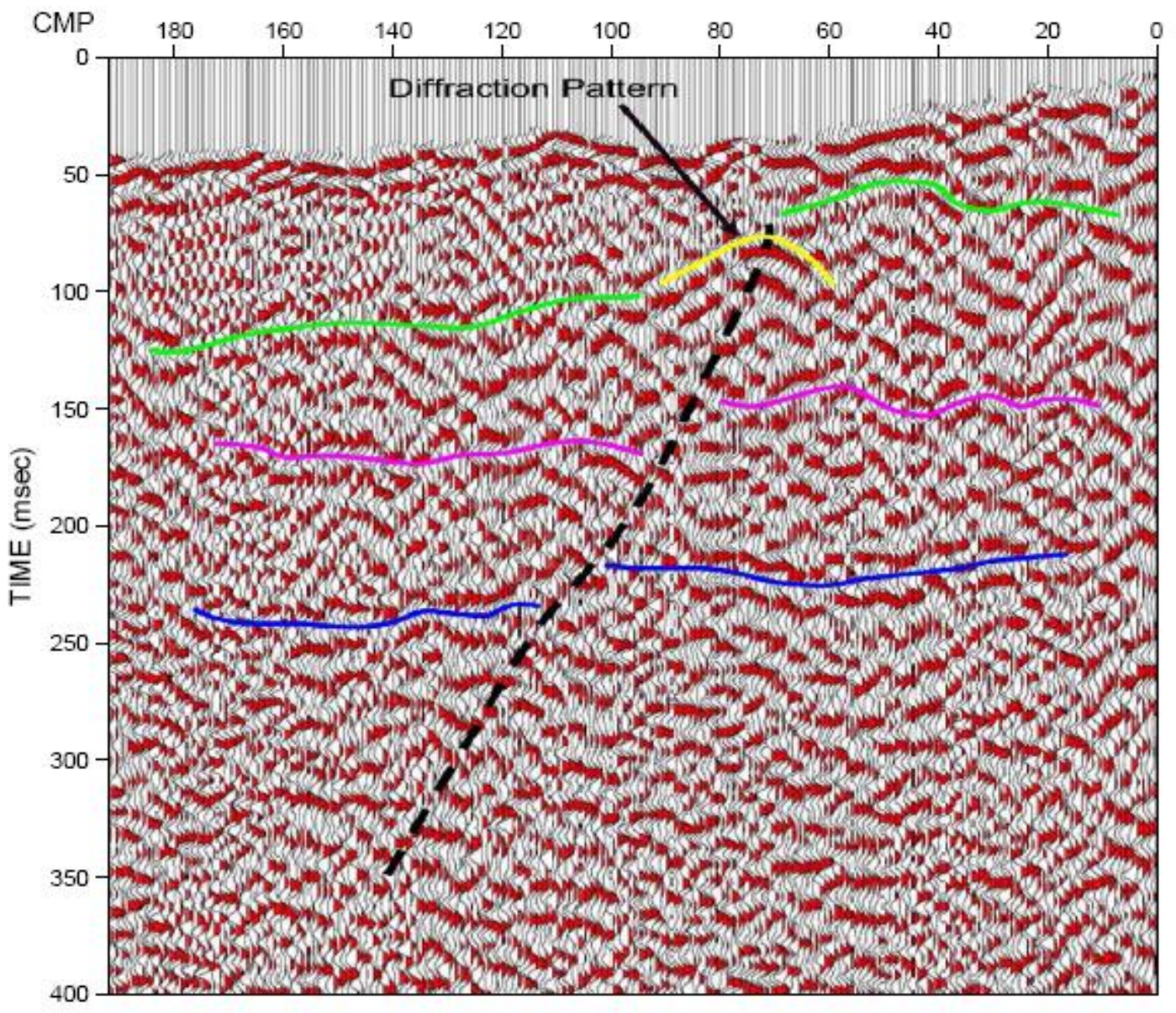

Figure 3-37. Interpreted seismic reflection profile from Line 1. 
LINE 2

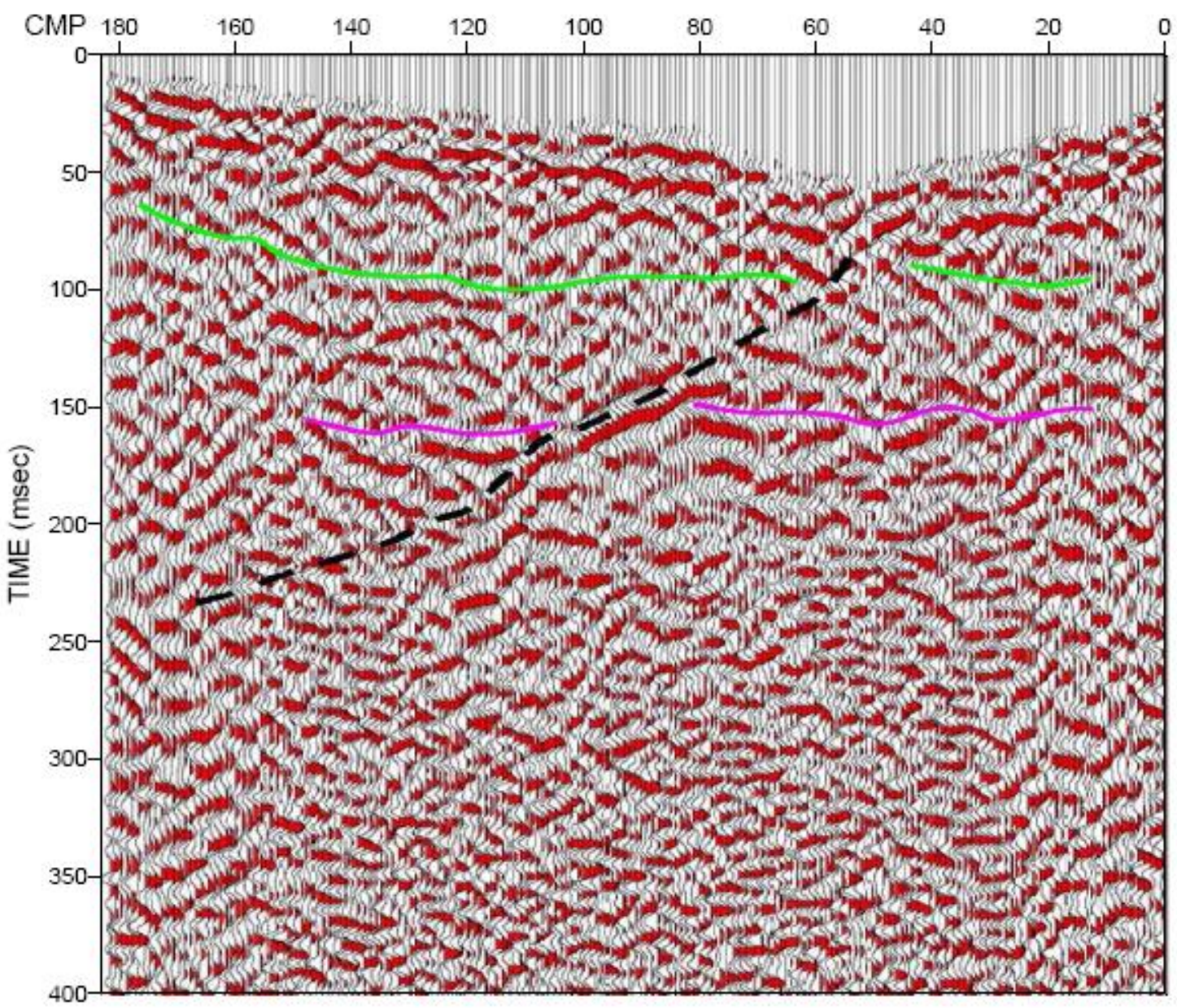

NE

Figure 3-38. Interpreted seismic reflection profile from Line 2. 


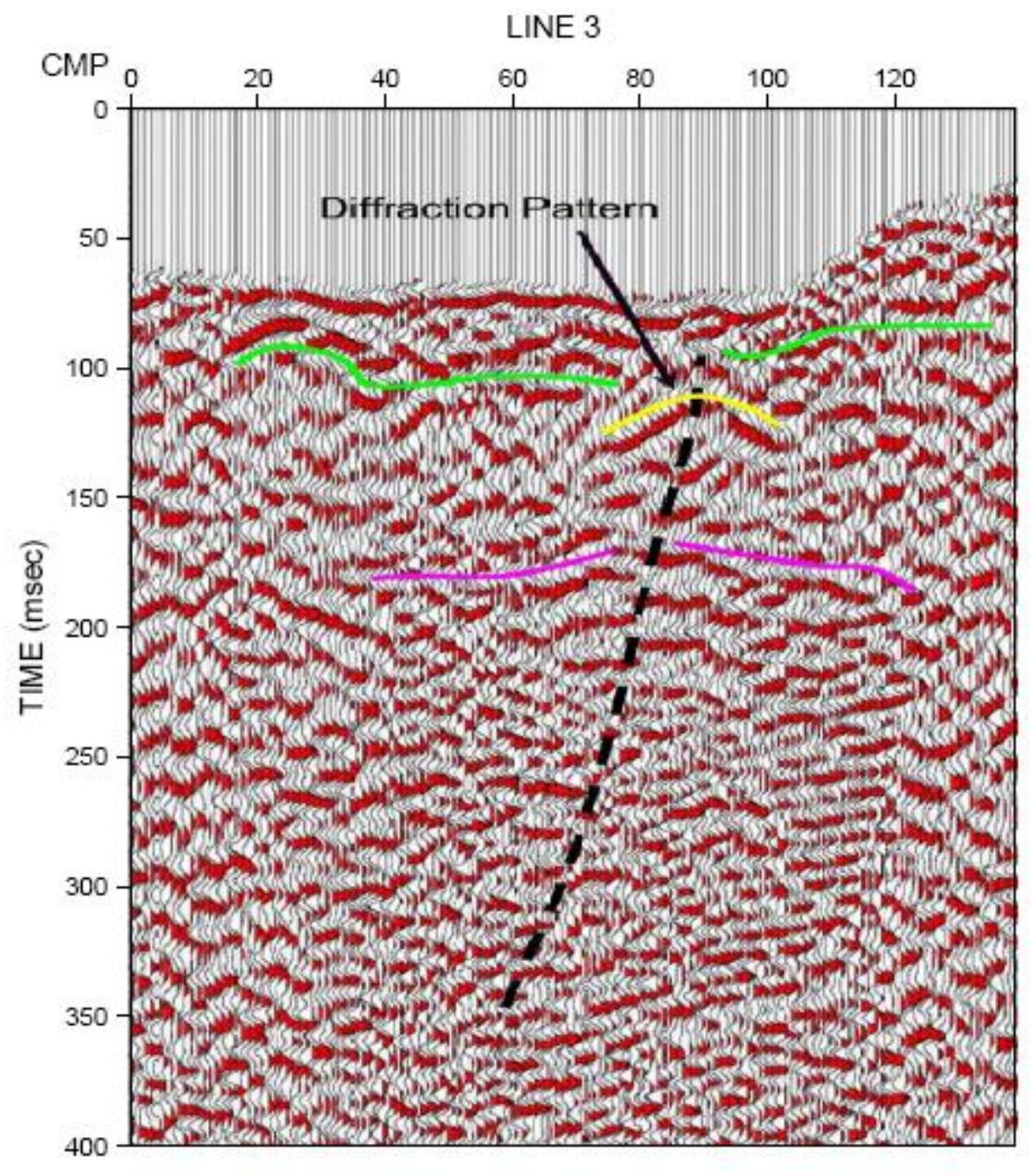

Figure 3-39. Interpreted seismic reflection profile from Line 3. 


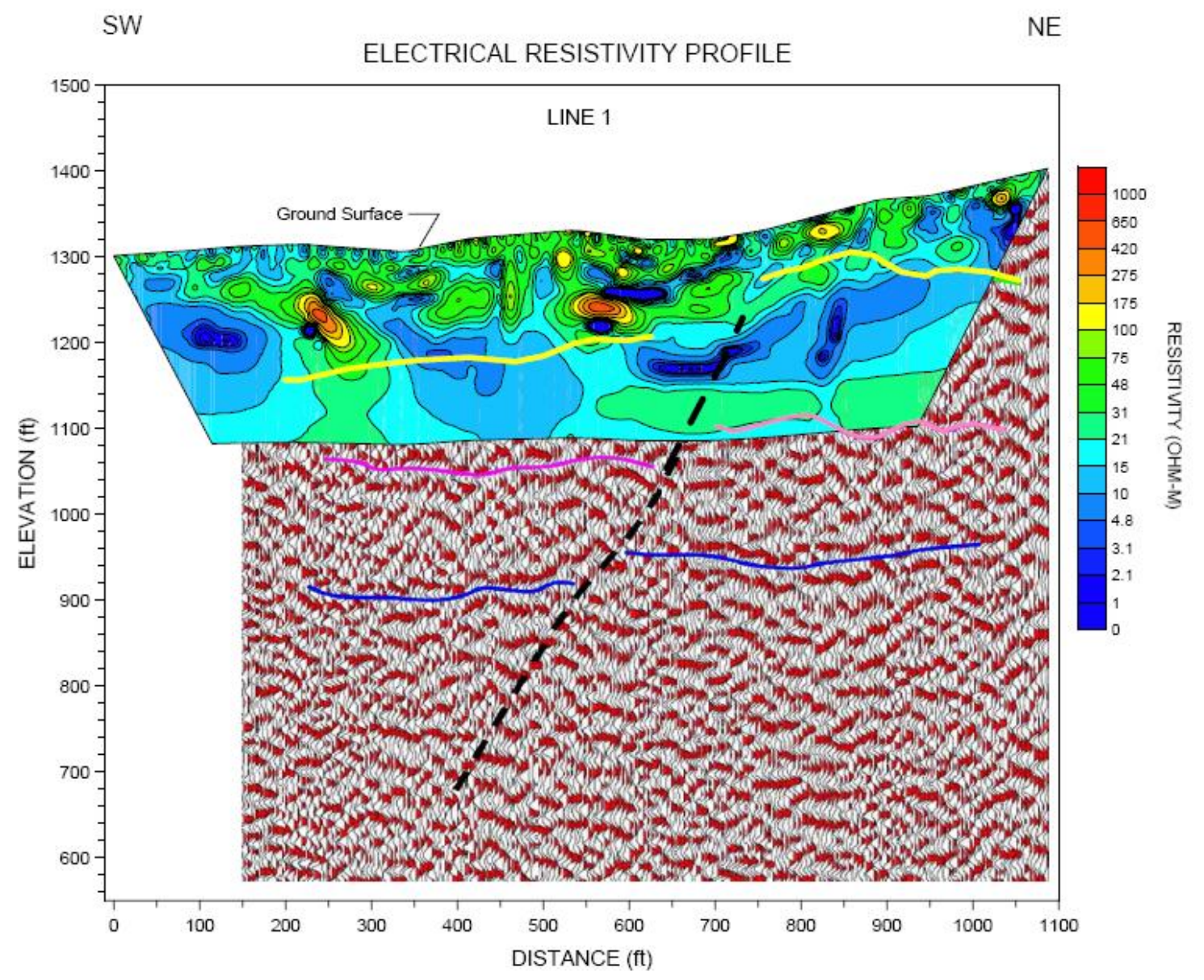

Figure 3-40. Superimposed plot of electrical resistivity and seismic reflection profiles from Line 1. 


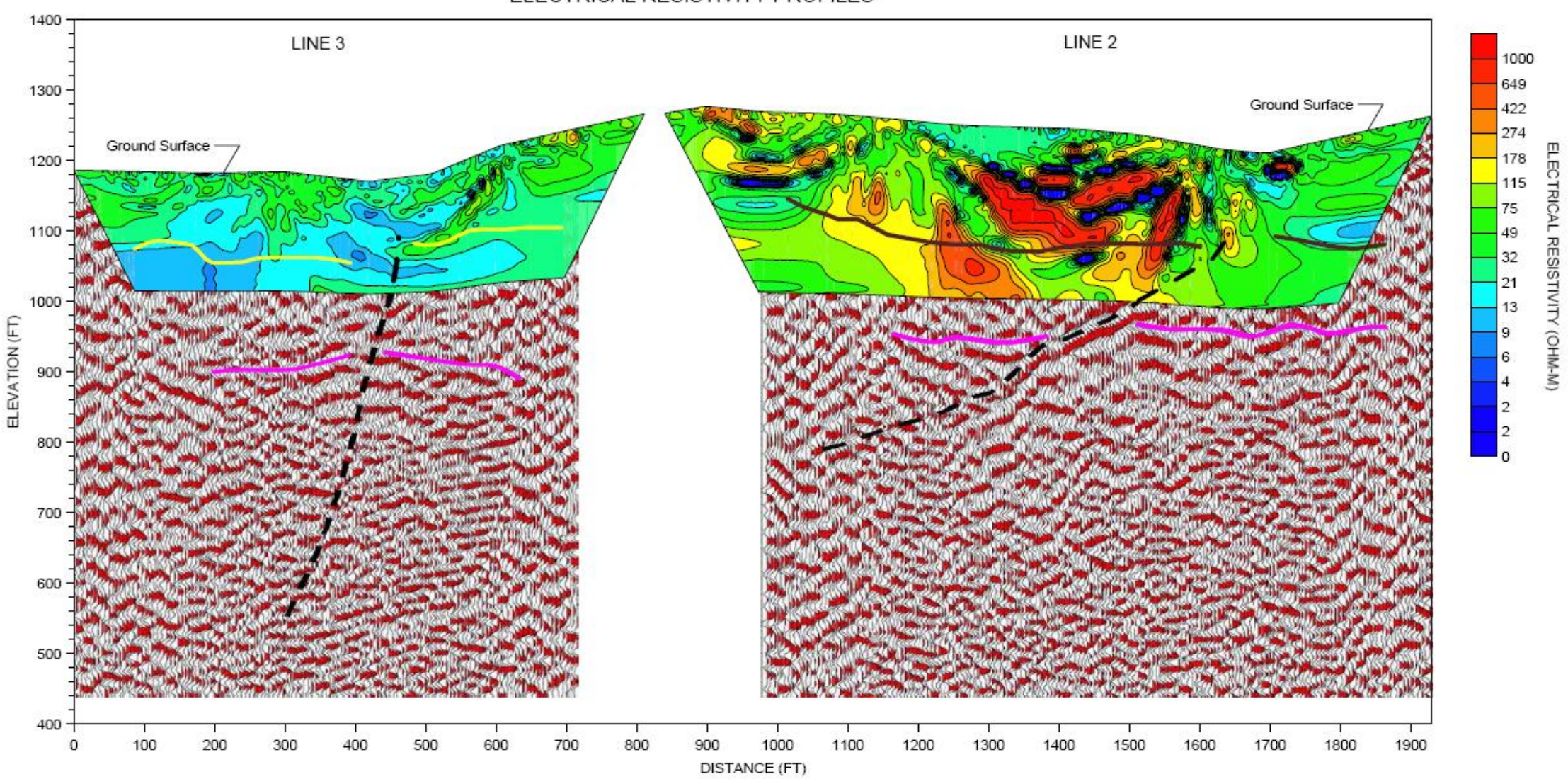

Figure 3-41. Superimposed plot of electrical resistivity and seismic profiles from Line 2(right) and Lin3 3(left). 


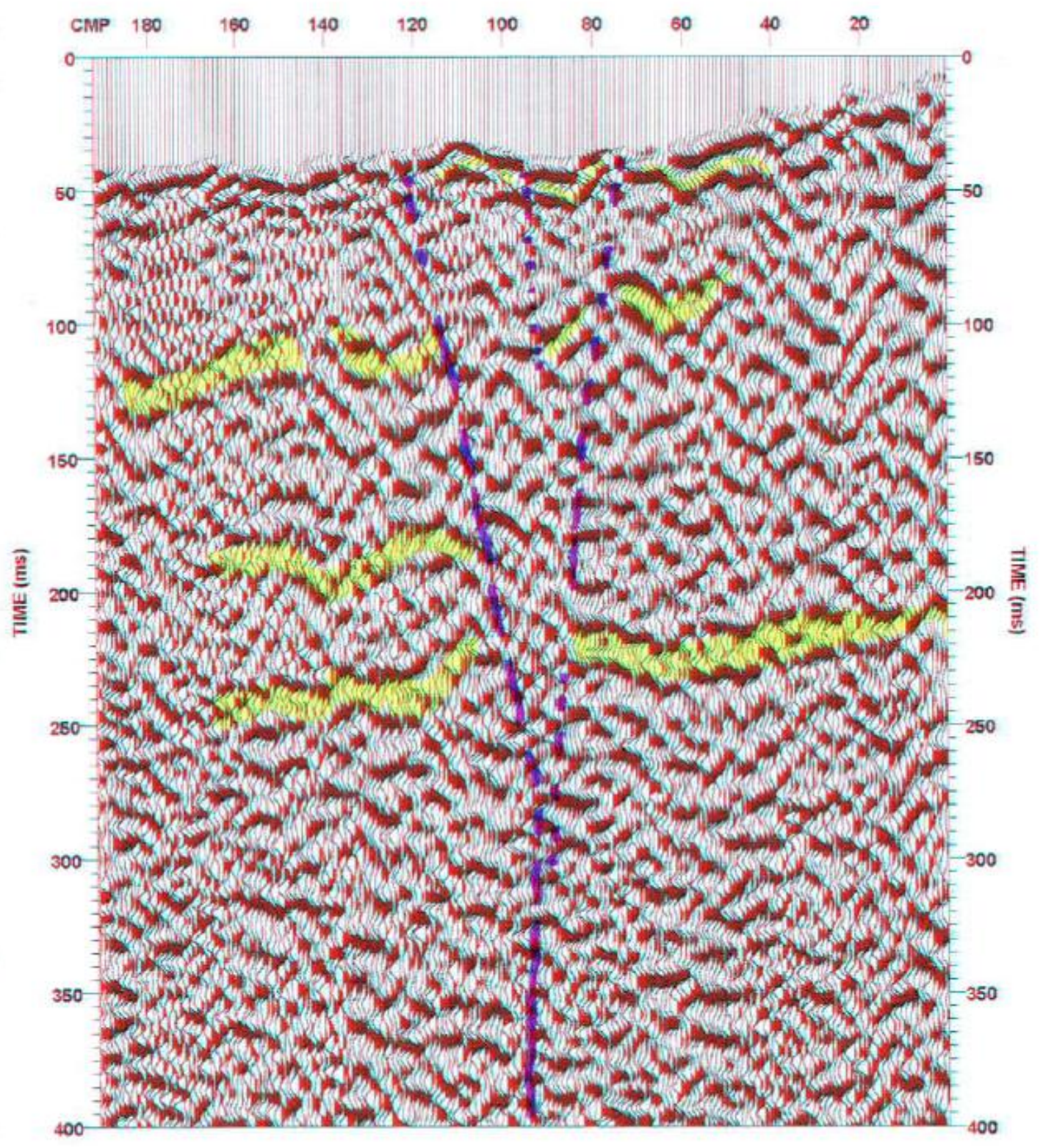

Figure 3-42. Alternative interpretation for Line 1 by Catchings (2009). 


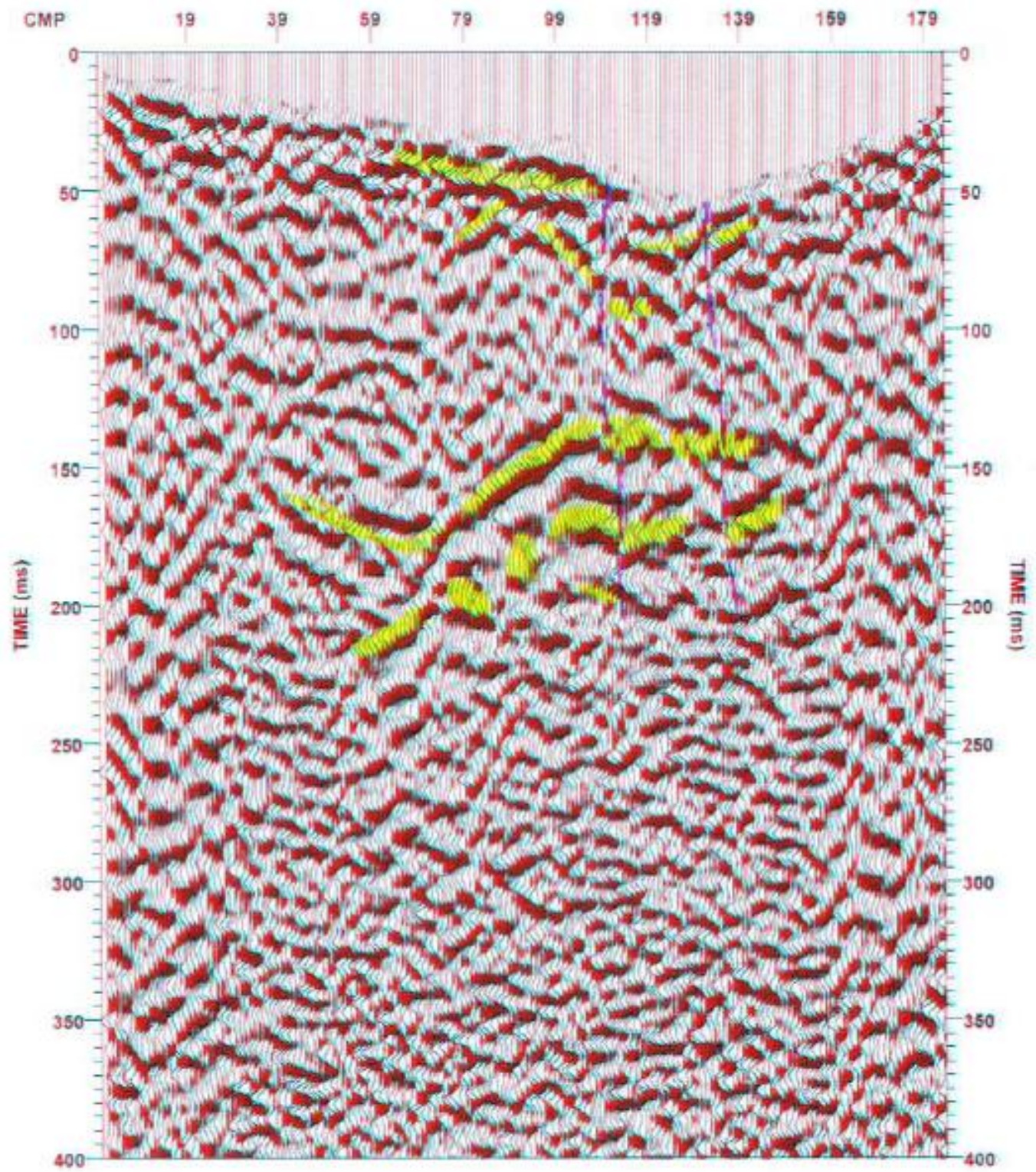

Figure 3-43. Alternative interpretation for Line 2 by Catchings (2009). 


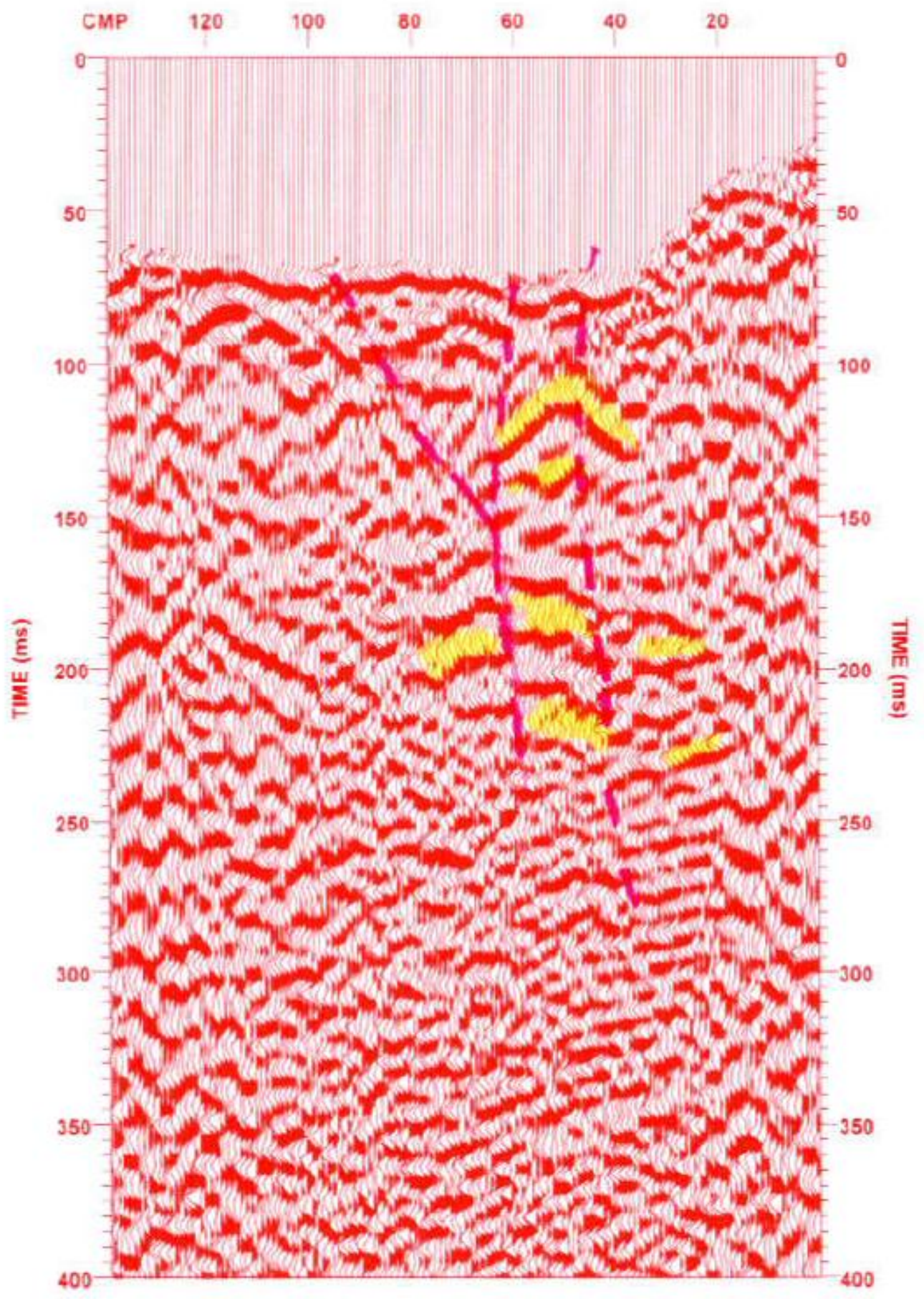

Figure 3-44. Alternative interpretation for Line 3 by Catchings (2009). 


\subsubsection{Surface geologic survey}

\subsubsection{Aerial Photography}

Black and white vertical stereographic aerial photographs from the U.S. Geological Survey library - dating back to 1939-were analyzed for identification of fault-related topographic features. Unfortunately, there are no typical topographic features, such as sagponds, linear depressions or offset drainage, within the LBNL property. This may result from the fact that the fault is inactive, and surficial deposits have covered most of the area. The analysis of the aerial photographs of a larger scale that includes the Hayward Fault and Wildcat Fault in the northern Bay Area is summarized in Chapter 3.1.1.

\subsubsection{Field Observation}

Field work near LBNL was conducted to understand the local geology and to find evidence of the Wildcat Fault trace. As previously described, the geologic and geomorphologic features of the Wildcat Fault are not evident in the LBNL property. Outcrops especially of the Claremont Formation are exposed along the eastern end of the LBNL property, the Fire Trail and Panoramic Way. Outcrop data were recorded on a GPS Garmin device and latter plot on Google Earth and topographic maps. Although the western side of the trace of the Wildcat Fault is covered by thick colluvial soil, the geologic map is intended to show the bedrock based on exposure and past borehole data. Therefore, no landslide and colluvial soils are shown in the geologic map.

\subsection{LBNL Property}

Bedrock exposure at LNBL is very limited. The only bedrock exposed near the study area is the Claremont chert and siltstone, which crops out in the eastern-end hills near the property line. Preston Jordan, LBNL geologist, explained that most of the geology of the LNBL site came from road cuts, trenches, and boring from geotechnical studies and borehole data from site restoration. During some of the geotechnical investigation, Jordan visited and mapped the Wildcat Fault, particularly the fault exposure during site evaluation of Building 84, near the parking lot construction west of Building 74, and along a road cut at Calvin Road. This information is plotted in the geologic map (see Appendix 1). 


\subsection{Fire Trail}

Several outcrops of volcanics of Moraga, cherts and siltstone of Claremont, and sandstone and siltstone of the Orinda Formation are exposed along the Fire Trail. Near the north entrance of Grizzly Peak Road, several blocks of weathered volcanic basalts and volcanoclastics were observed on the ground and exposed at road cut. The exposure near the road cut are highly weathered and fractured near the trace of the Wildcat Fault. It is less weathered farther east along the Fire Trail (see map for details of the outcrop location). Figure 3-45 shows an example of the weathered and fractured volcanic rock near Grizzly Peak.

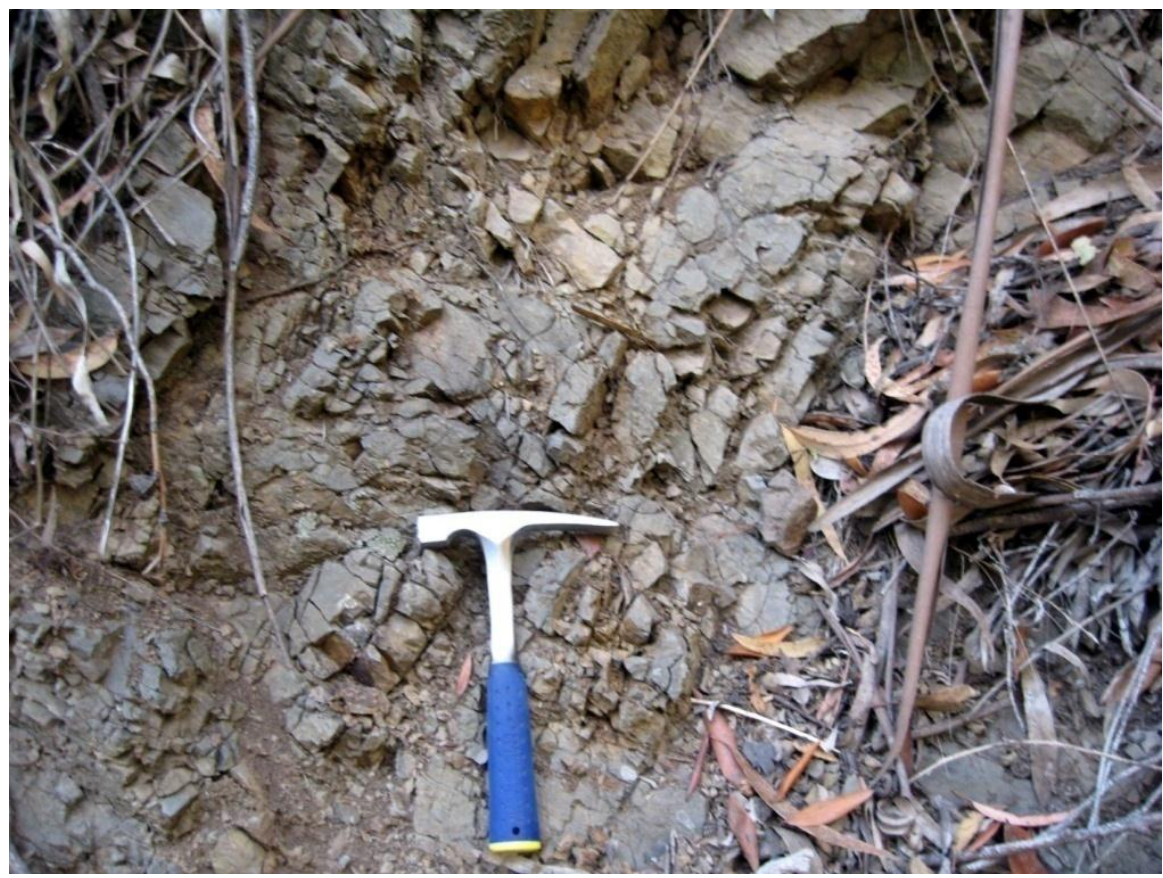

Figure 3-45. Weathered and fractured volcanics of the Moraga Formation

The outcrops of the Claremont cherts and siltstone are well exposed along the Fire Trail. The bedding varies from subhorizontal to steep dip to the south. Locally, the beds are overturned and tightly folded (Figure 3-46) in the shape of a wave. The cherts are moderately weathered, usually pale yellow with fractures visible normal to the bedding. The average fracture space is $10 \mathrm{~cm}$. Each bed contains millmetric intercalations of a thin ( $~ 5 \mathrm{~mm}$ wide) layer of gray siltstone. Black cherts are also commonly interbedded with light-colored chert. The average thickness of the chert varies from 2 to $10 \mathrm{~cm}$. Occasionally, thick (up to $50 \mathrm{~cm}$ ), weathered tuffeceous siltistone, oxidized to an orange color, is found intercalated with bedded cherts. 


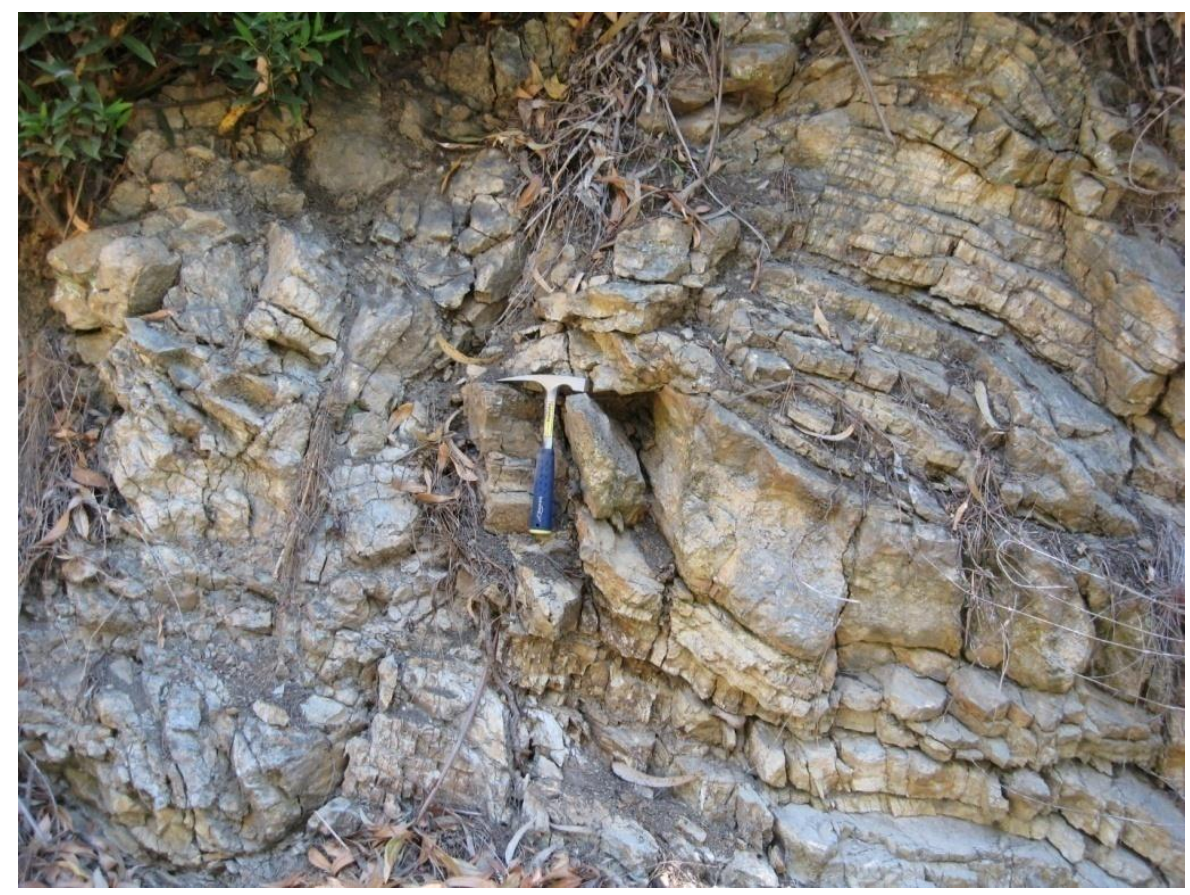

Figure 3-46. Overturned beds of cherts and siltstone of the Claremont Fm, Fire Trail, Berkeley

The Claremont formation is also well exposed along the Sugar Loaf ridge, where a couple of low-angle normal faults have cut and displaced the beds (Figure 3-47). In another outcrop, several horizontal slickensides were observed in planes oblique to the bedding, showing right-lateral strike-slip movement. In addition, several blocks of chert with slickensides were found on the ground near the trace of the Wildcat Fault at Sugar Loaf Saddle. 


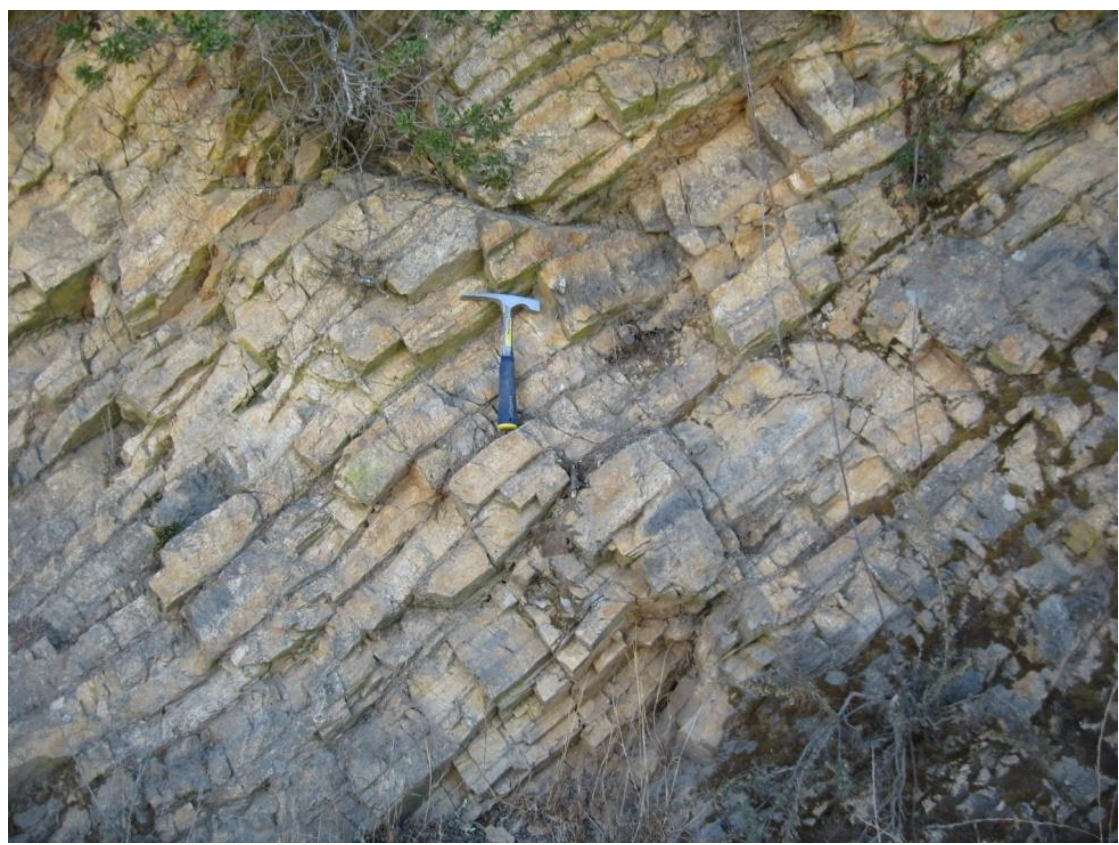

Figure 3-47. Outcrop of bedded Claremont chert and siltstone along the Fire Trail, Berkeley

Outcrops of the Orinda Formation are rare along the Fire Trail. One of the main and typical exposures is near a creek that connects Grizzly Peak and Panoramic Way. There, mottled reddish mudstone, with scaly cleavages and greenish, unconsolidated, and friable fine-grain sandstone to siltstone are exposed at the sidewalk and along the creek (Figure 3-48). According to HLA (1985), several boring tests have been conducted near Bldg 74. The weak consolidated siltstone of the Orinda Formation is found below $45 \mathrm{ft}$ of colluvial soil. 


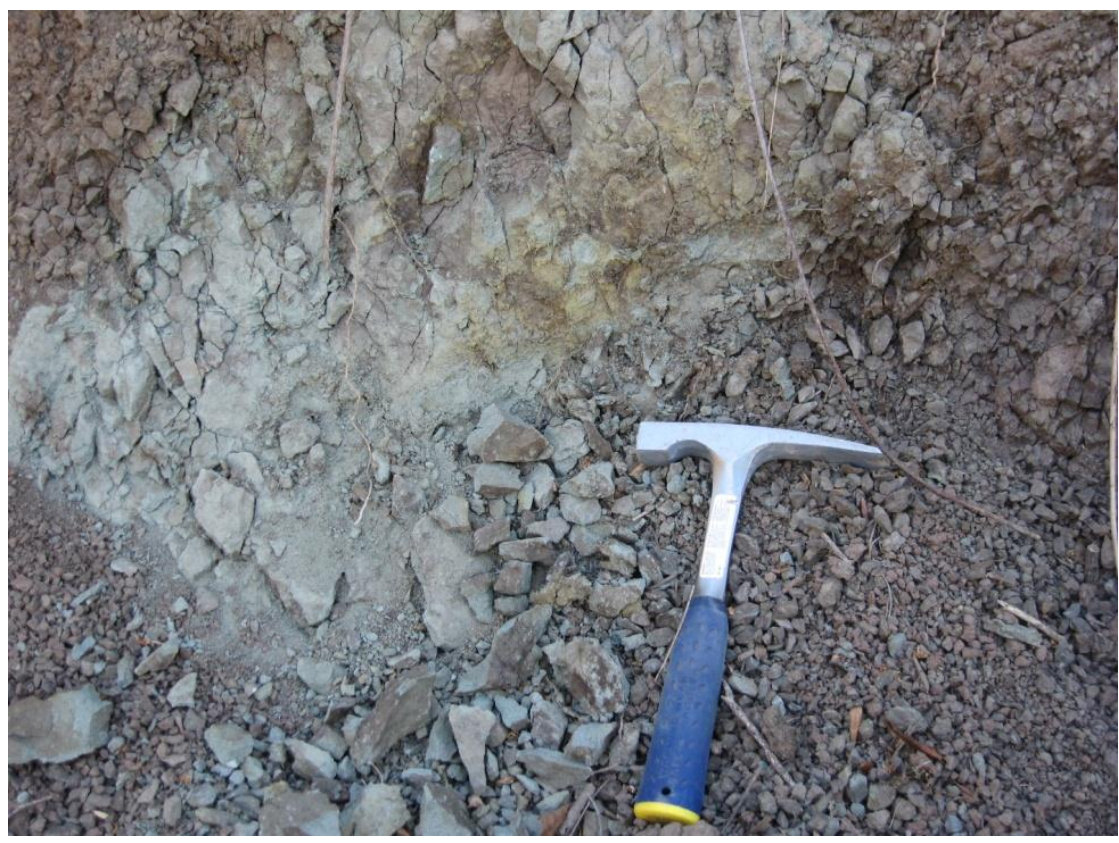

Figure 3-48. Outcrop of typical mottled weathered reddish and greenish siltstone of Orinda formation in the Fire Trail, Berkeley

\subsection{Panoramic Way}

Along Panoramic Way, which follows a ridge south of LBNL property, cherts of Claremont formation are the bedrock that makes the Sugar Loaf ridge. Several blocks of weathered cherts with slickensides were found near the saddle, suggesting the presence of a fault. About $20 \mathrm{~m}$ to the west of the saddle, an outcrop of bedded chert with slickenside indicates right-lateral strike-slip fault movement (Figure 3-49). The fault plane is oriented 37 degrees to the northwest dipping 78 degrees to the northwest, and it shows slickenside with rake of $20^{\circ}$. Near the fault, cherts are fractured in small blocks ranging from 1-2 cm fracture spacing. The bed strikes 27 degrees to the northwest and dips 32 degrees to northeast. 


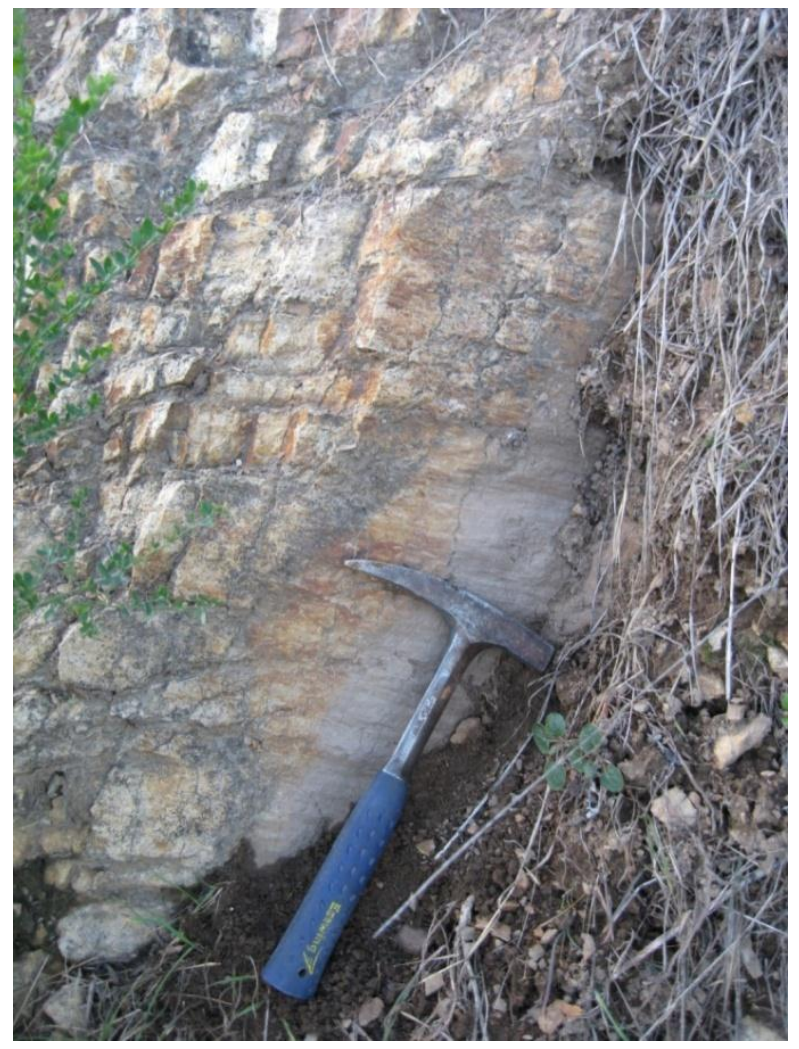

Figure 3-49. Sub-horizontal slickensides in Cleramont chert

About $200 \mathrm{~m}$ toward the west, down the hill, there is an exposure of weathered chert that soon changes to coherent white well sorted fine sandstone. They are exposed at the road cut. This soon changes to a highly fractured and weathered light-grey silicious siltstone that easily crumbles. The average fracture spacing is $<0.5 \mathrm{~cm}$. The bedding is somewhat shadowy.. It is oriented 47 to the northwest and dips 48 degrees northeast.

Walking down the hill, along the slope and on the ground, a zone of transition is observed between fine, massive, light-brown sandstone to a gray to brown silt sandstone. They are cut by fine black seams of about $1 \mathrm{~mm}$ wide, striking N32-59E and dipping 40-52 degrees to southeast. This appears to be a zone of disturbance; however, no plane was identified. This zone, when projected to the Fire Trail, it's not observed in the road cut or on the ground, although cherts are observed a few meters west of the Fire Trail. It is possible that a fault splay may be responsible for mixing cherts and sediments from the Orinda Formation in this region. 


\subsubsection{Trench studies}

To improve our confidence in the location of the trace of the Wildcat Fault-its geometry, deformation, and changes in fault properties along the fault length - trenching locations were chosen after a detailed surface geological survey. The criteria used in selecting trench locations were based on (a) proximity of the previously described or observed fault location; (b) the ability to dig at least three trenches, as requested by the Central Research Institute of Electric Power Industry (CRIEPI) to examine changes in fault properties, and (c) digging deep enough to characterize the bedrock (lithologic variation and distribution of deformation across the fault). The location of two trenches, NUMO TR1 and TR2, were near Trenches T1 and T2 of WLA (2008) and Trench A of HLA (1980), respectively. Trench NUMOTR3 was located near Calvin Road.

On December 9, 2008, an excavator started trenching NUMO TR0 near Building 74, about $10 \mathrm{~m}$ to the south and parallel to Trench T1 of WLA, 2008. The plan was to have a step trench. Excavation started by opening an area of about $5 \mathrm{~m}$ wide into the hill (Figure 3-50). During excavation, a clear contact between the cherts in the east and medium-to-coarse-grained sandstone in the west was observed on the north wall, but before notes and samples could be taken, the site was buried because of safety issues. The lithological contact aligned with the orientation of the trace of the Wildcat Fault from previous work (Figure 3-51).

Soon after Trench NUMO TR0 was closed, trench NUMO TR1 was excavated about $10 \mathrm{~m}$ further to the south. Two subsequent trenches were excavated in the north. Trench NUMO TR2 was excavated north of the LBNL property line, right next to the access gate to the Fire Trail. A shallow trench, NUMO TR3, was excavated near Calvin Road and in between NUMO TR1 and NUMO TR2. Figure 3-52 illustrates the location of the three trenches (photo taken from the Fire Trail). The hills in the eastern part of Building 74 correspond to the Claremont formation. Most of the topography in the western side of Building 74 is composed of thick landslide and colluvium deposits. 


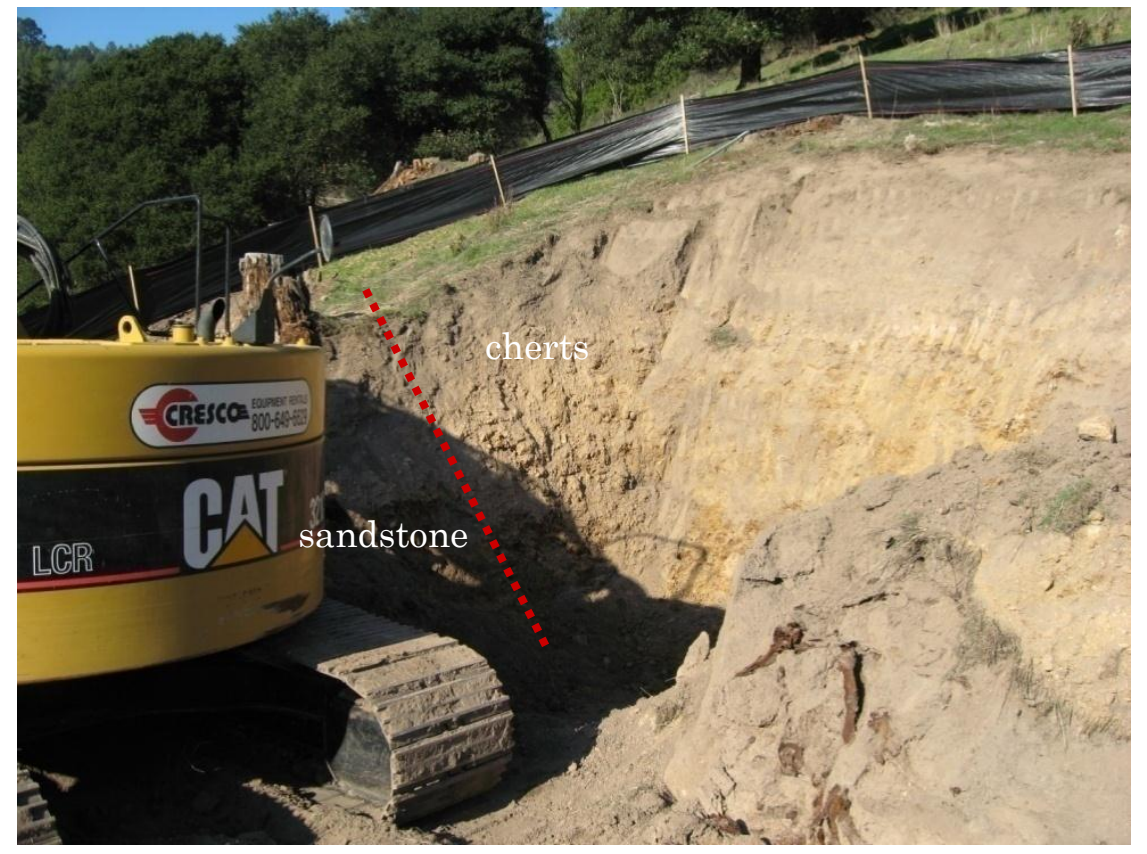

Figure 3-50. Proposed location of Trench TR0. On the north wall, the contact between cherts in the $\mathrm{E}$ and sandstone in the $\mathrm{W}$ follows the approximate location of the red dotted line.

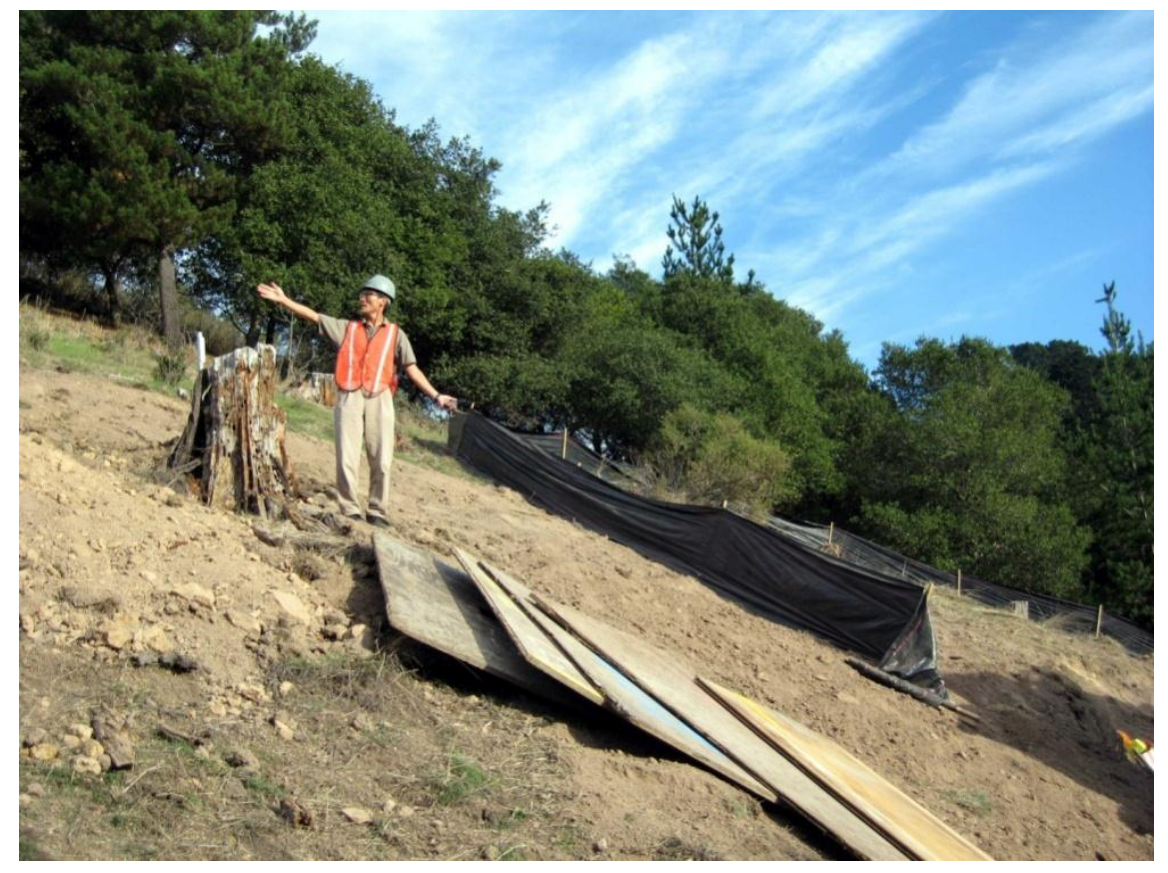

Figure 3-51. Trench TR0 after filled, and location of trench TR1 


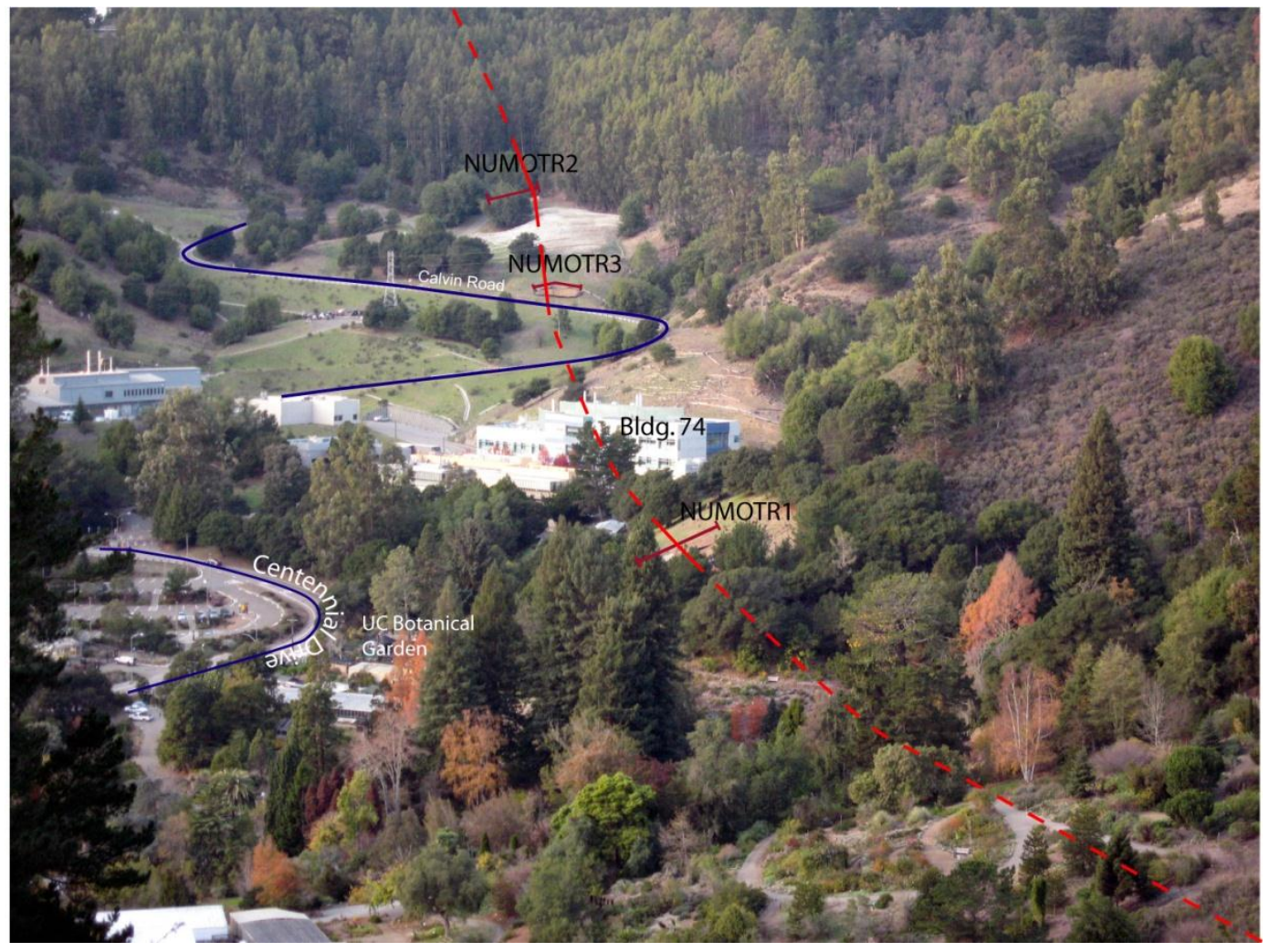

Figure 3-52. View from the Fire Trail of three open NUMO trenches. The lengths of NUMOTR01 and TR02 are approximate. Centennial Road and Building 74 are used as point of reference.

Over about five working days, a team of five geologists, including four from CRIEPI, logged the trenches. Trench TR1 and TR2 were the longest (max. $20 \mathrm{~m}$ long) and deepest (over $4 \mathrm{~m}$ deep) trenches, while Trench TR3 was the shallowest, less then $1.5 \mathrm{~m}$ deep and about $10 \mathrm{~m}$ long. Only the walls facing north were logged.

A detailed description of the trenches has been conducted by the CRIEPI team, including comprehensive logging and sampling(see Kiho et al, 2009 for details). In this section, only the main structures will be described and compared with observation of faulting described in previous geotechnical reports. 


\subsubsection{Chronology of Trench Excavation}

最初のトレンチの掘削箇所は GPL（General Purpose Laboratory）建設の予備地質調査で WLA がトレンチ観察を行った場所（図参照）から $20 \mathrm{~m}$ 程度南に選定した。当初、安全性を考慮して階段 状に掘削する仕様であったが、結果的には幅 $5 \mathrm{~m}$ 、深度 $6 \mathrm{~m}$ 、奥行き $10 \mathrm{~m}$ のほぼ垂直な切羽が掘削さ れた（以後 NUMO-TR0 と呼ぶ）。12月 9 日の掘削当日の午後簡単な壁面の観察を行った際、Wildcat 断層として考えられる SanPablo 層とClaremont 層の境界が WLA のレポートに基づき当初推察してい た位置より $5 \mathrm{~m}$ 程度東側にずれていた。このことから、WLA の観察した Wildcat 断層は地すべりに より西にずれて傾いたとの推測が立てられる。この付近の地層は $\mathrm{C}$ 等級の未固結のゆるんだ土砂の 被りの為、安全規制上階段状にすることは不可能で、壁面を 45 度のスロープに掘削する必要が生じ た。しかし、安全基準をクリアするまで切羽を大きくし、土砂を掘削移動させる事が予算と場所の制 約上困難となった為、この NUMO-TR0 トレンチは止む無く埋め戻しとなった。

次に掘削する箇所の選択枝としては北側に移動し、WLA のトレンチの近くに掘削するかあるいは、 埋め戻した箇所のさらに南側に移動するかであった。前者はWLA のレポートから基盤岩や断層の深 度や位置がほぼ予測できることから、確実に断層を切ってトレンチが掘削できると予想できた。反面、 最初に掘削し埋め戻したトレンチで観察された断層の位置とは矛盾する。このことから、最終的には さらに南側に $20 \mathrm{~m}$ 移動した地点で掘削することと決定した（図参照）。このトレンチを以下 NUMO-TR1 と呼ぶ。

北の 2 号トレンチの掘削箇所は基盤岩が露頭している Fire Trail 沿いも候補であったが、散歩やジ ヨギングをする住人が多い為、安全性を考えて避けた。Fire Trail に隣接している UC バークレー校 の Field Station for Behavioral Research (FSBR) 敷地内も候補に挙げた。しかし、FSBR 内では Wildcat 断層は Moraga 層と Claremont 層のコンタクトであると予想される。FSBR 付近の Moraga 層は貫入岩 の可能性も捨てきれないこと(Brimhall, 2009, personal communication)、断層が正確に何処を通ってい るか不明な事から、FSBR 内でのトレンチ掘削も断念した。Harding Lawson Associates（1980）は過去 に FireTrail から南に下がった地点でトレンチ掘削を行い（トレンチA 図参照） Sobrante Sandstone と Orinda Clay の境界面を断層として確認している。確実に断層を切ってトレンチを掘削する目的でこ のトレンチAの南側にトレンチ NUMO-TR2 を掘削した。

NUMO-TR1、および TR2 トレンチにおいて断層が発見されない恐れがあった為、3 番目のトレン チを北と南の中間地点に掘削することに決定した（NUMO-TR3）。当該箇所は近くを通る Calvin Road を建設する際、あるいは直上の排水溝を造成する際に削られたと思われる SlickenSide のある岩石が いくつも転がっているのが見られ、基盤岩も路頭している。Jordan（2008）は切り盛りで造成した 
Calvin Road が造成されたさい、現場に立ち会って、当該場所で断層を確認していた。

\subsubsection{Faults observed in the trenches:}

\section{NUMO TR1:}

Lat: $37^{\circ} 52^{\prime} 31.99^{\prime \prime} \mathrm{N}$ and $37^{\circ} 52^{\prime} 31.42^{\prime \prime N}$ Long: $122^{\circ} 14^{\prime} 15.13^{\prime \prime} \mathrm{W}$ and $122^{\circ} 14^{\prime} 15.62^{\prime \prime} \mathrm{W}$

Trench NUMO TR1 is oriented N15E. It is about $20 \mathrm{~m}$ long and 1 meter wide, with depth varying from 2 to $4 \mathrm{~m}$ (Figure 3-53).

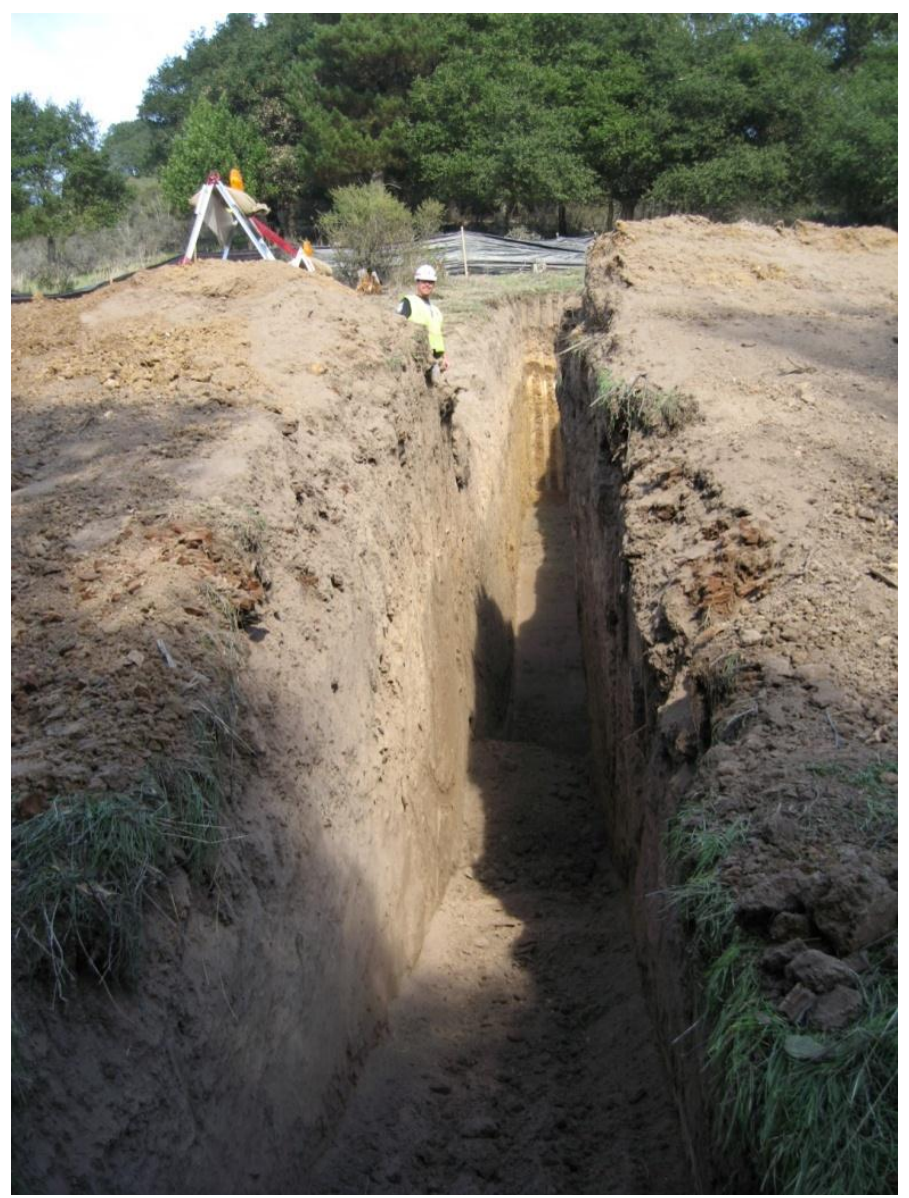

Figure 3-53. View to the east of trench NUMO TR1 before hydraulic shoring was placed.

This trench is located about $20 \mathrm{~m}$ south of trench T1 of WLA (2008). Bedrock was exposed only in the last eight meters towards to the east. Only the wall facing north was logged. The rest of 
the trench was composed of colluvium/landslide material and therefore not included in the trench $\log$ (Figure 3-54). According to the description by Kiho et al (2009), a fault trending N64W and dipping 40E was observed near the middle of the trench. The fault is defined as a thin layer of gouge between highly fractured and weathered cherts in the east and a zone of mixed layers of thin sandstone and siltstone in the west. See Kiho et al's report (2009) for a more detailed trench description.

The fault orientation and projected location matches with the Wildcat fault described in Trenches T2 and T3 of WLA (2008). This relatively low dip fault (about 40 degrees to the east) has been interpreted as part of flower structure by WLA (2008).

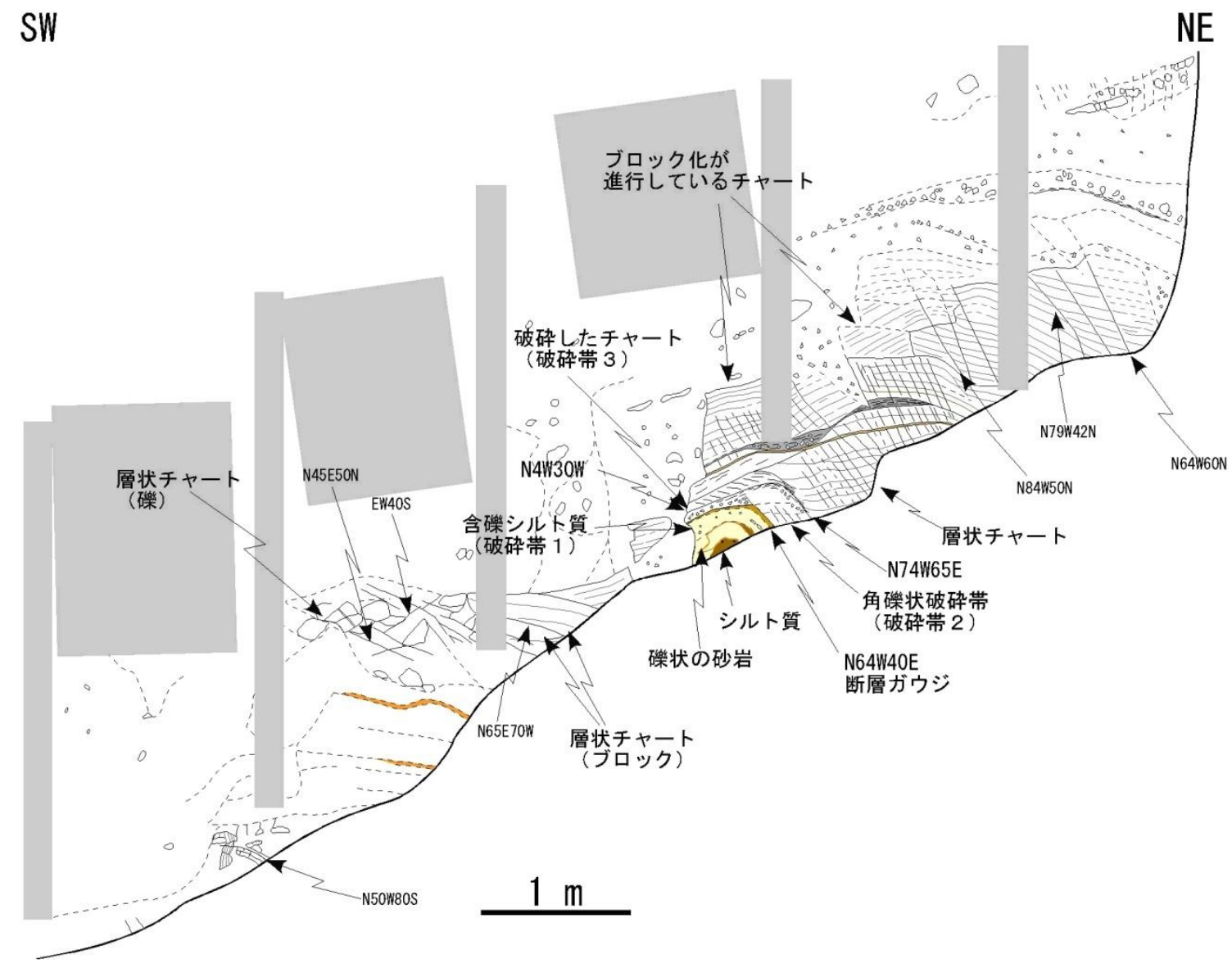

Figure 3-54. Trench log of NUMO TR1 by Kiho et al (2009) 


\section{NUMO TR2:}

Lat: $37^{\circ} 52^{\prime} 46.94^{\prime \prime} \mathrm{N}$ and $37^{\circ} 52^{\prime} 47.07^{\prime N} \mathrm{~N}$ Long: $122^{\circ} 14^{\prime} 25.70^{\prime \prime} \mathrm{W}$ and $122^{\circ} 14^{\prime} 25.19^{\prime \prime} \mathrm{W}$

Trench NUMO TR2 is oriented N79E. It is about $14 \mathrm{~m}$ long, $1 \mathrm{~m}$ wide and $4 \mathrm{~m}$ deep (Figure 3-55).

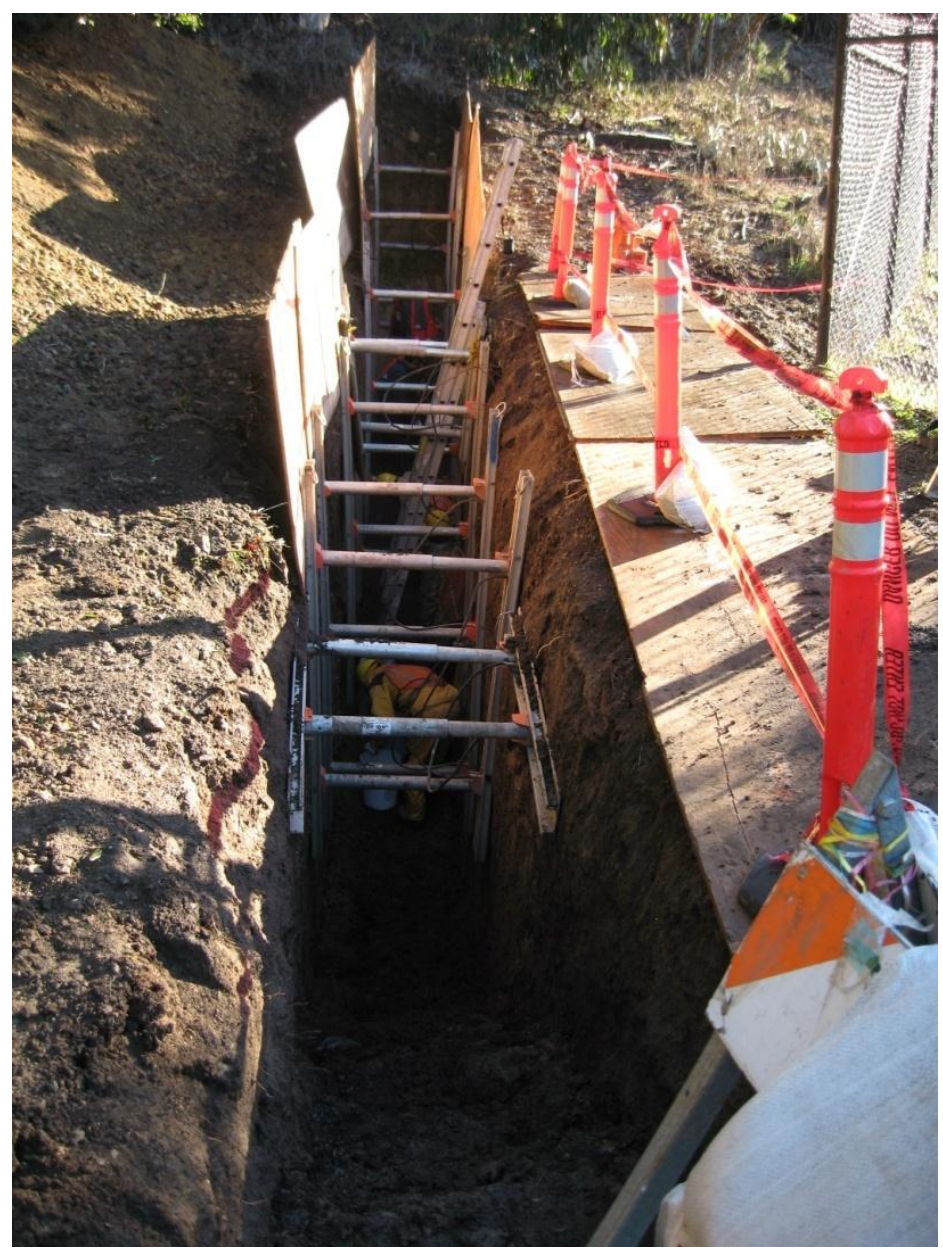

Figure 3-55. View to the east of trench NUMO TR2 near the north gate to the Fire trail.

Two main faults were observed during trench logging. A major contact fault was mapped between light-brown-medium to fine-grain, moderately consolidated sandstone, possibly of the Sobrante or Claremont Formation, and a mixture of dark-red mudstone and grey-to-light-green fine siltstone of the Orinda Formation. The fault is located in the eastern end of the trench. The photo below (Figure 3-56) taken on the wall facing east illustrates the deformation observed mostly in the lower siltstone to mudstone of the Orinda Formation. The deformation is concentrated in the plastic dark-red mudstone. The kinematic indicator includes shear bands $(\mathrm{R}$ 
and P), S-C fabric, and asymmetric features in the gray siltstone. All these indicate a right-lateral sense of shear. A sample from the contact was taken by Kiho et al (2009).

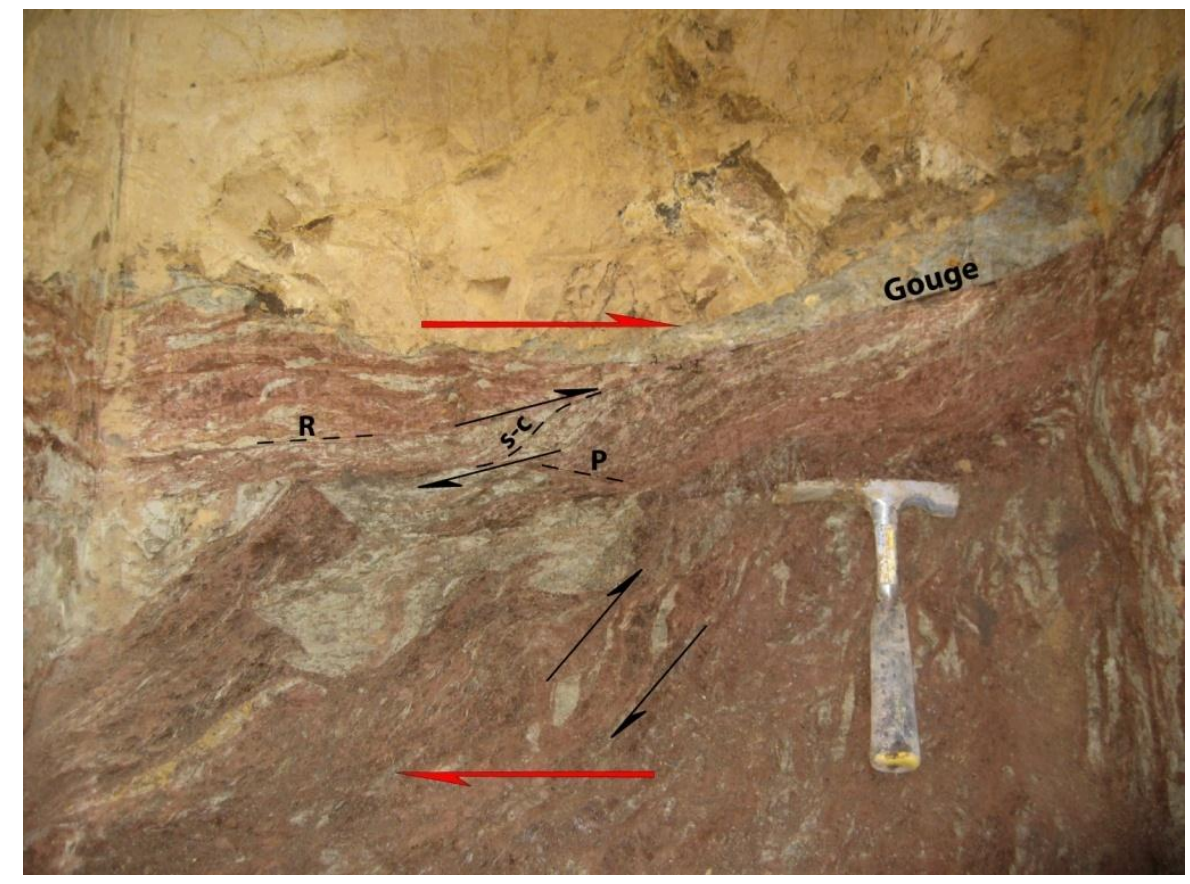

Figure 3-56. Main fault in NUMOTR2 showing main deformation concentrated in the Orinda Fm.

In more detail, thin seams of clay gouge (about $1 \mathrm{~cm}$ thick) separate portions of the deformed Orinda Formation (Figure 3-57). In the massive sandstone (Figure 3-58), the deformation is concentrated in several vertical to subvertical sets of dark seams less than $0.5 \mathrm{~cm}$ wide in average. They are cut by fractures apparently filled with calcium carbonate. 


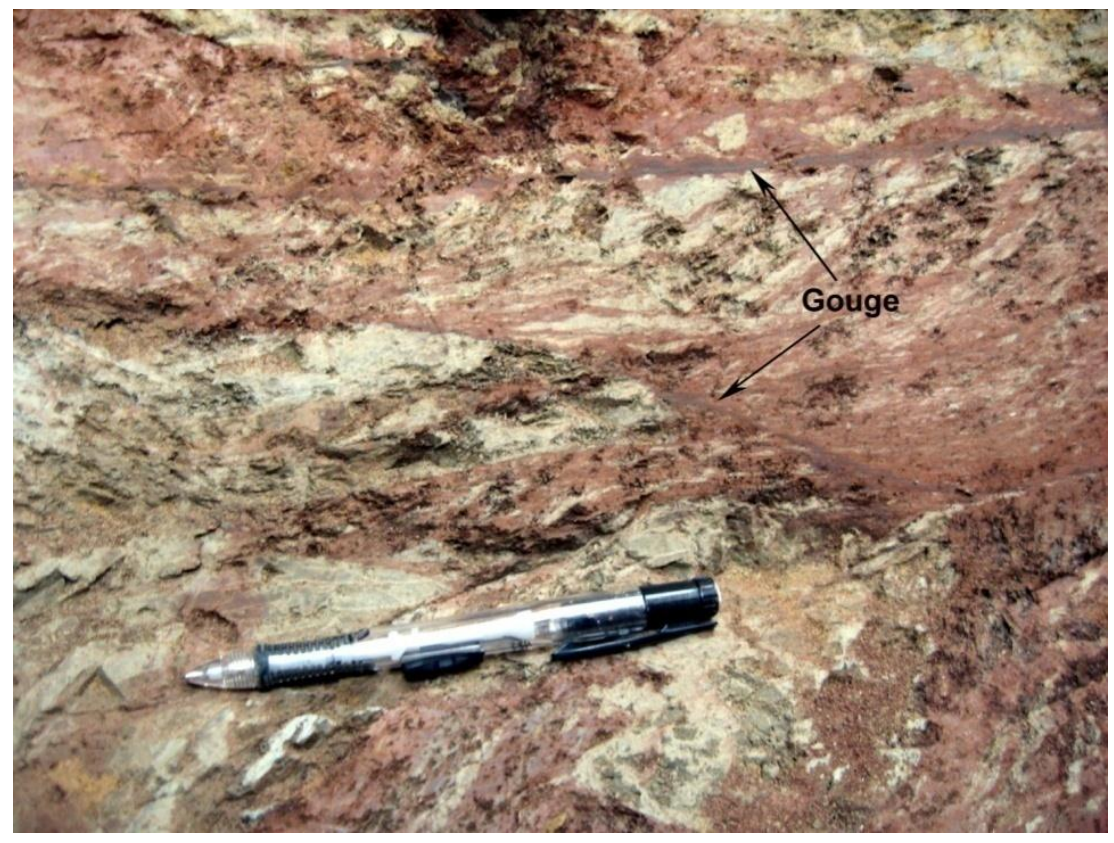

Figure 3-57. Clay gouges in faulted Orinda Formation

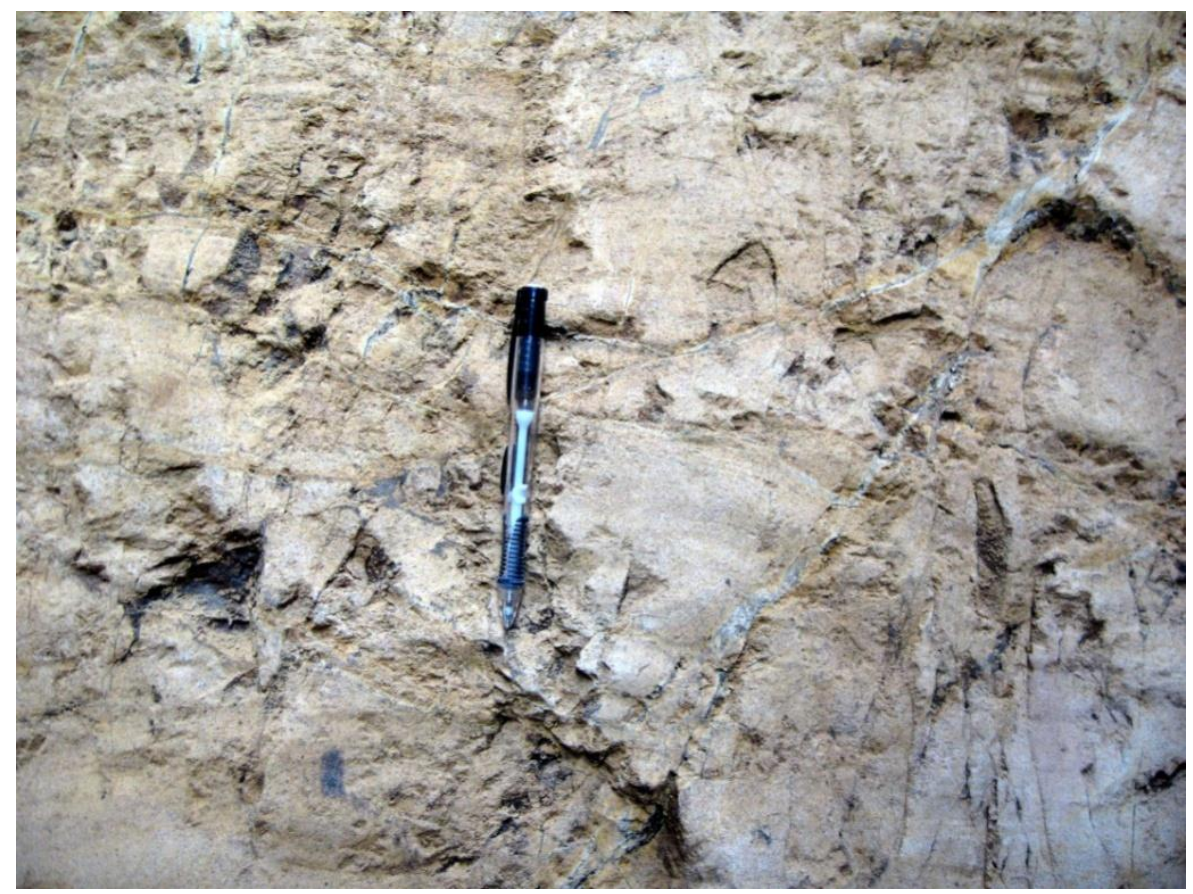

Figure 3-58. Several subvertical and subparallel dark seams observed in the sandstone

The sandstone described in NUMO TR2 is similar to that described as a fault contact in Trench A of HLA (1980). HLA also observed black-coated fractures, possible the black seams described in the sandstones of NUMO TR2. In addition, red and green clay gouge and a zone of 
highly sheared rock occur between the sandstone of Sobrante or Claremont formations and the siltstone of the Orinda formation (HLA, 1980).

The second major fault was observed in the middle of the trench. The fault orientation is northwest with low angle dipping to the northeast (Figure 3-59). The fault contacts the mottled dark red mudstone, bleached to oxidized siltstone and medium-grained green to gray sandstone of the Orinda formation with dark mudstone with scaly cleavage. In the scaly cleavage, fine slickensides are observed on the cleavage plane (Figure 3-60).

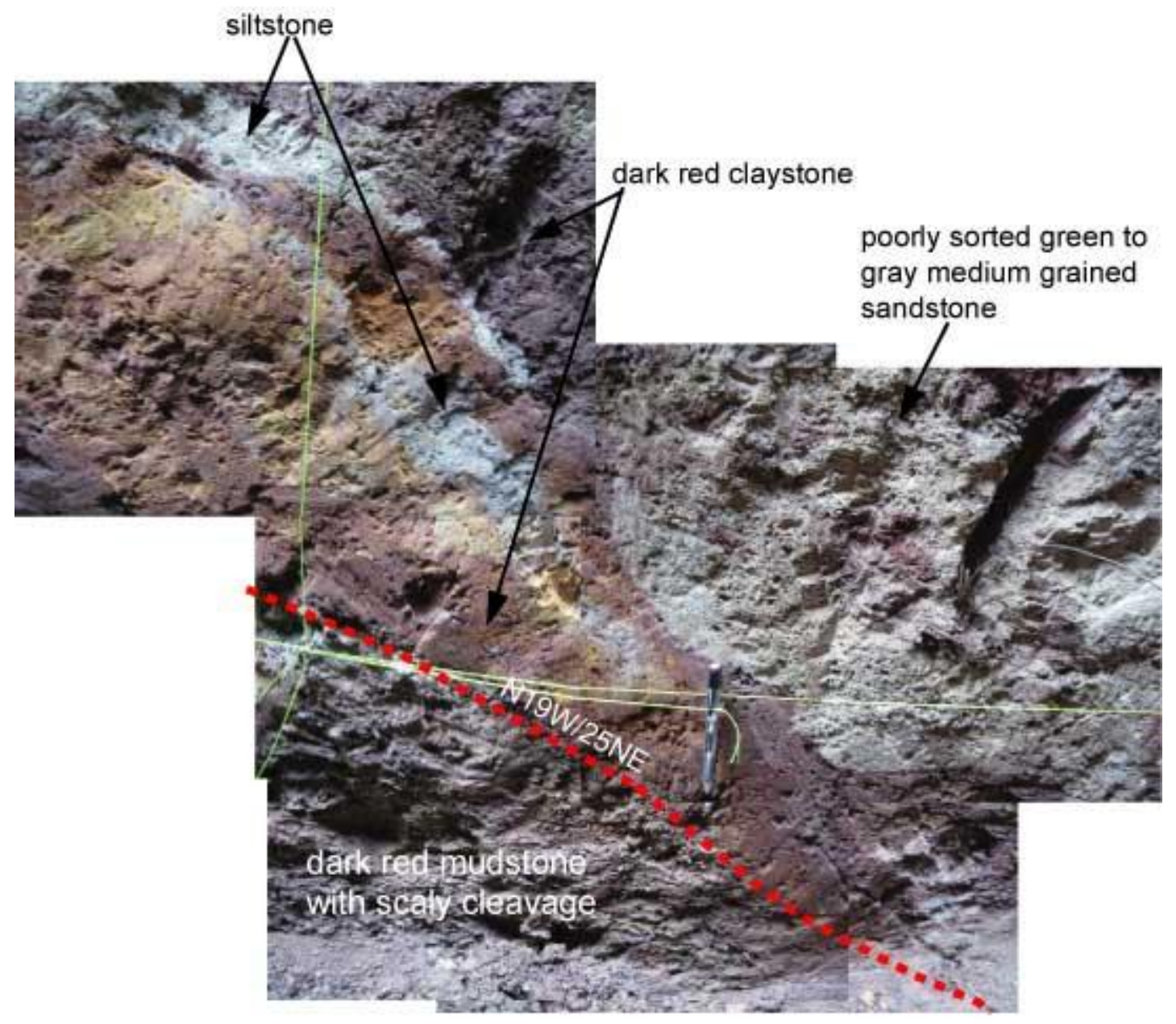

Figure 3-59. Mosaic of fault observed in the middle of NUMO TR2 


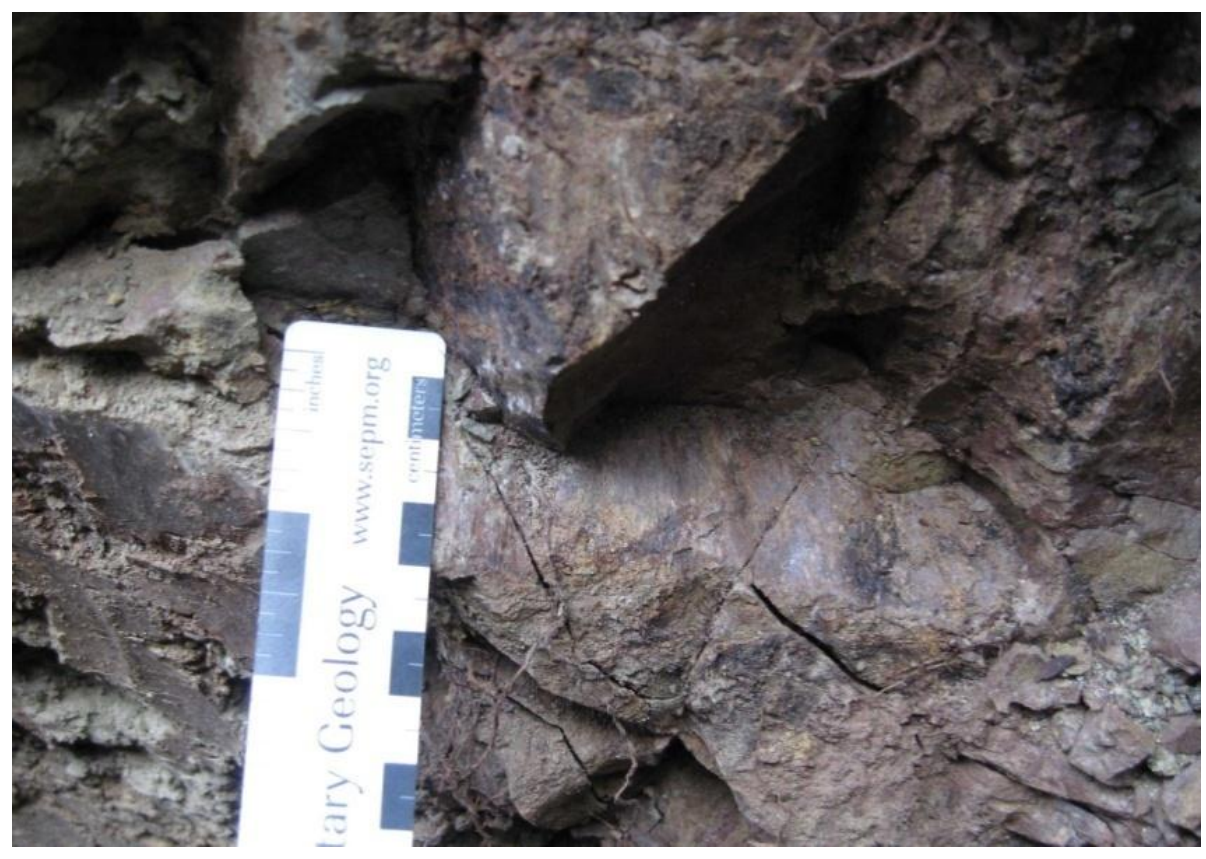

Figure 3-60. Scaly cleavage observed in dark-red mudstone, showing fine slickenside on cleavage plane

Figure 3-61 illustrates the overall distribution of geologic features in NUMO TR2. The sketch put together by CRIEPI has been described in detail by Kiho et al (2009). 
West

East
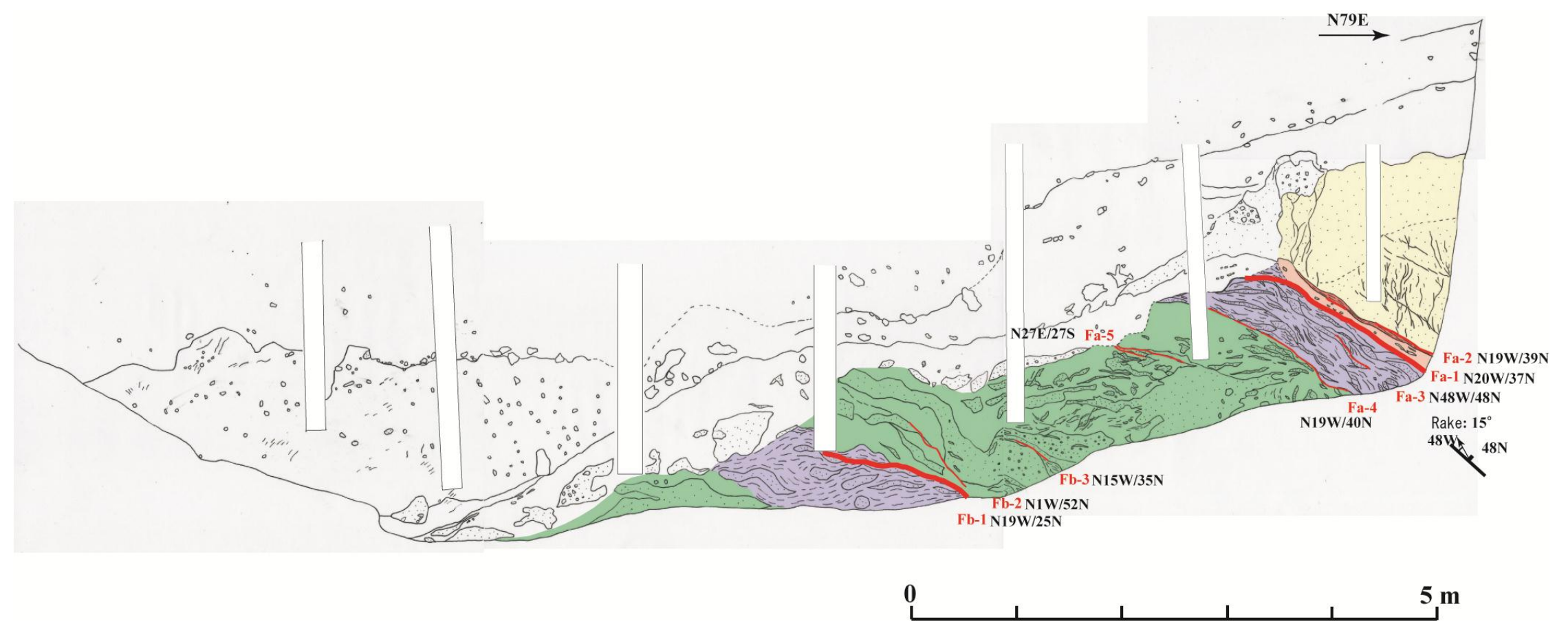

Figure 3-61. Sketch of Trench NUMO TR2. The main fault was observed in the west end of the trench. The fault is the contact between the sandstone of the Sobrante/Claremont Formation and the siltstone and mudstone of the Orinda Formation. 


\section{$\underline{\text { NUMO TR3 }}$}

Trench NUMO TR3 was excavated parallel to a ditch a few meters above the hill from Calvin Road (see Figure 3-52). It is oriented N67E and is about $10 \mathrm{~m}$ long, $1 \mathrm{~m}$ wide, and $1.3 \mathrm{~m}$ deep (Figure 3-62). During the visit by NUMO and CRIEPI personnel in September 2008, Preston Jordan led a field trip to the location where NUMO TR3 was trenched. On the ground, several blocks of cherts with slickensides were found. According to Jordan, the fault was observed during the construction of Calvin Road, back in 2001, although it was not recorded in the geotechnical reports. In the geologic map by WLA (2008), the area of NUMO TR3 is covered by a Quaternary landslide. Our field reconnaissance survey and trench work indicated that the area was mostly bedrock.

In this trench, a fault contact was observed at Lat: $37^{\circ} 52^{\prime} 43.14^{\prime \prime} \mathrm{N}$ and Long: $122^{\circ} 14^{\prime} 22.65^{\prime \prime} \mathrm{W}$.

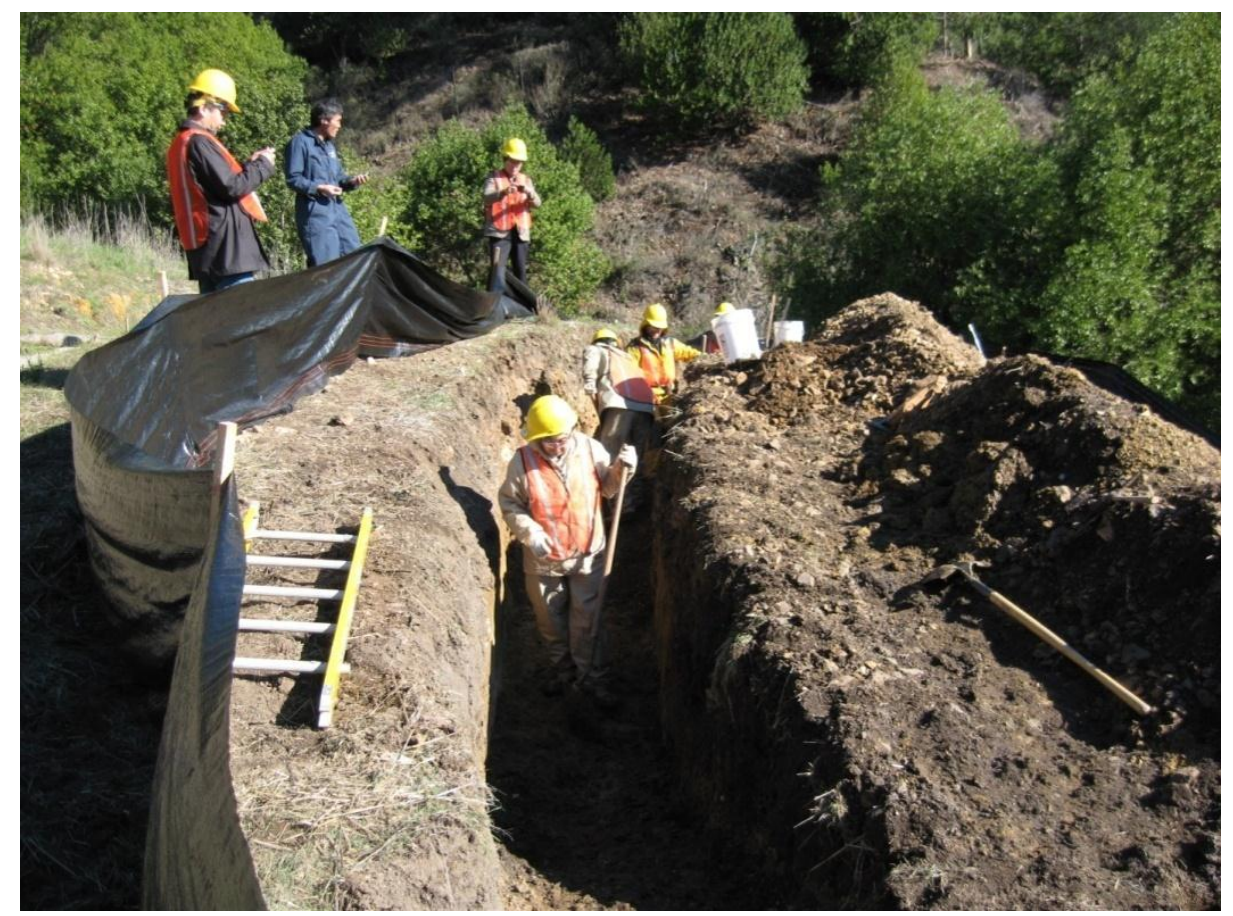

Figure 3-62. View to the east of the trench NUMOTR3

The fault zone is a sharp contact between light-green siltstone of the Orinda Formation in the west, and cherts of the Cleramont Formation in the east. In the fault contact, a 2-3 cm up to $25 \mathrm{~cm}$ thick zone of gouge was observed. In the gouge, angular fragments of siltstone and cherts were 
aligned parallel to the fault plane. The fault orientation is $\mathrm{N} 25 \mathrm{~W}$ and dip subvertically to the SW. The cherts near the fault were highly fractured (Figure 3-63).

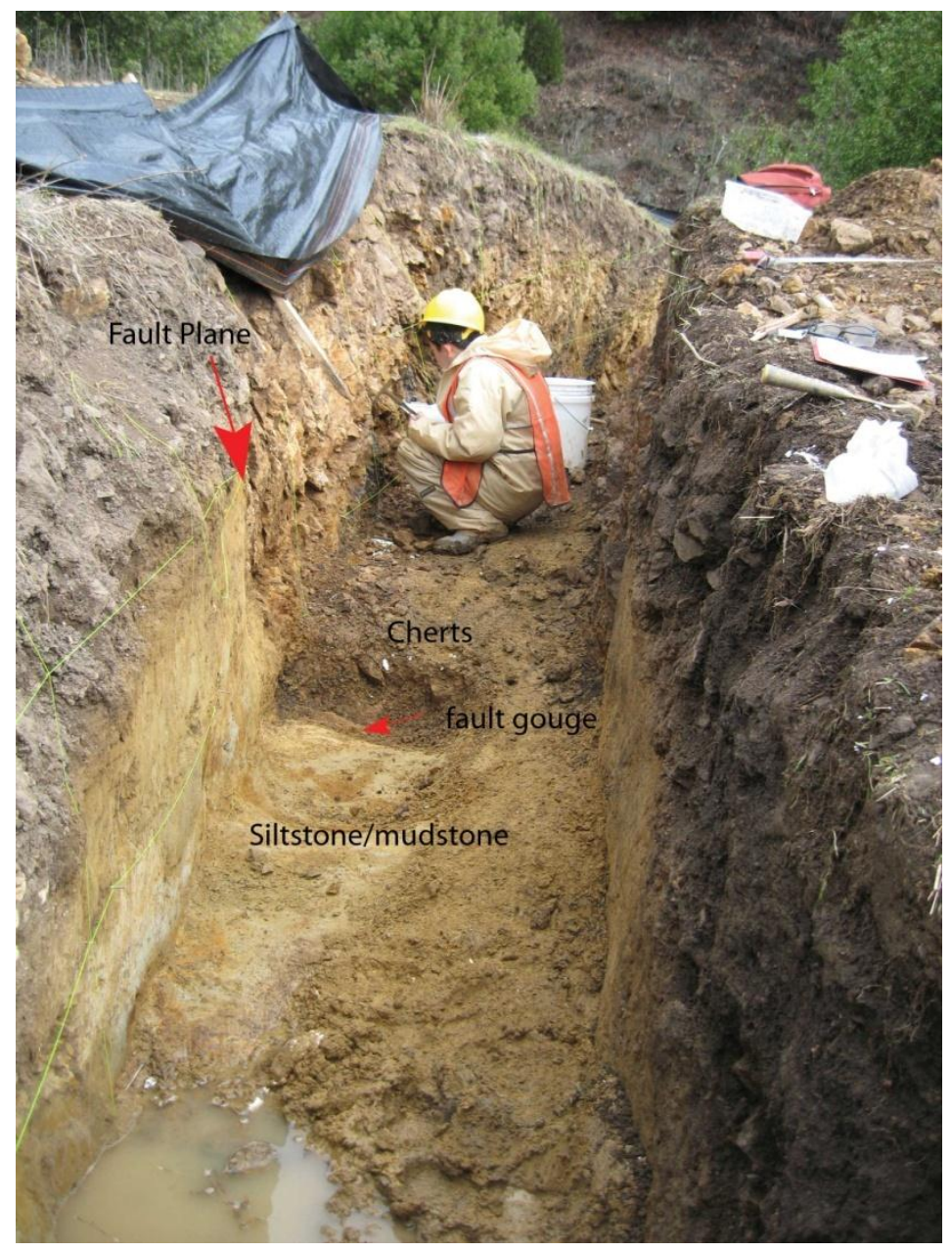

Figure 3-63. West view to NUMO TR3. Note the sharp fault contact between the Orinda and Claremont Formations

Approximately four meters east of the fault plane, dikes of weathered, well-sorted, fine-grain sandstone were observed occupying a concordant position with respect to chert bedding. Two sandstone dikes $10-15 \mathrm{~cm}$ wide were observed, containing no visible planar structures. The surrounding cherts are moderately fractured (Figure 3-64). The sandstone dikes have been described by Untermann (1935), Graham et al. (1984) and Page (1950) and are common features in the Claremont Formation. Untermann described the presence of sandstone dikes near the zone of disturbance associated with the Wildcat Fault and observed the west side of the fault. Those 
sandstone dikes assume all positions from horizontal to vertical, generally discordant to chert bedding (Untermann, 1935). Page (1950) described sandstone dikes during the Broadway tunnel construction, noting that in the tunnel, the dikes commonly crosscut surrounding strata, but in some instances they were sill-like, nearly parallel to beds of cherts and shales. Their size and shape were variable, ranging from an inch $(2.5 \mathrm{~cm})$ to at least $82 \mathrm{ft}(25 \mathrm{~m})$ in thickness, some exceeding $200 \mathrm{ft}(60 \mathrm{~m})$ in length. The shape varies from tabular to bizarre forms. In the Broadway Tunnel, sandstone dikes were not observed at the contact between Claremont and Orinda Formations, suggesting that the dikes were formed prior to the deposition of Orinda sediments because no clastic dikes were found in the latter (Page, 1950).

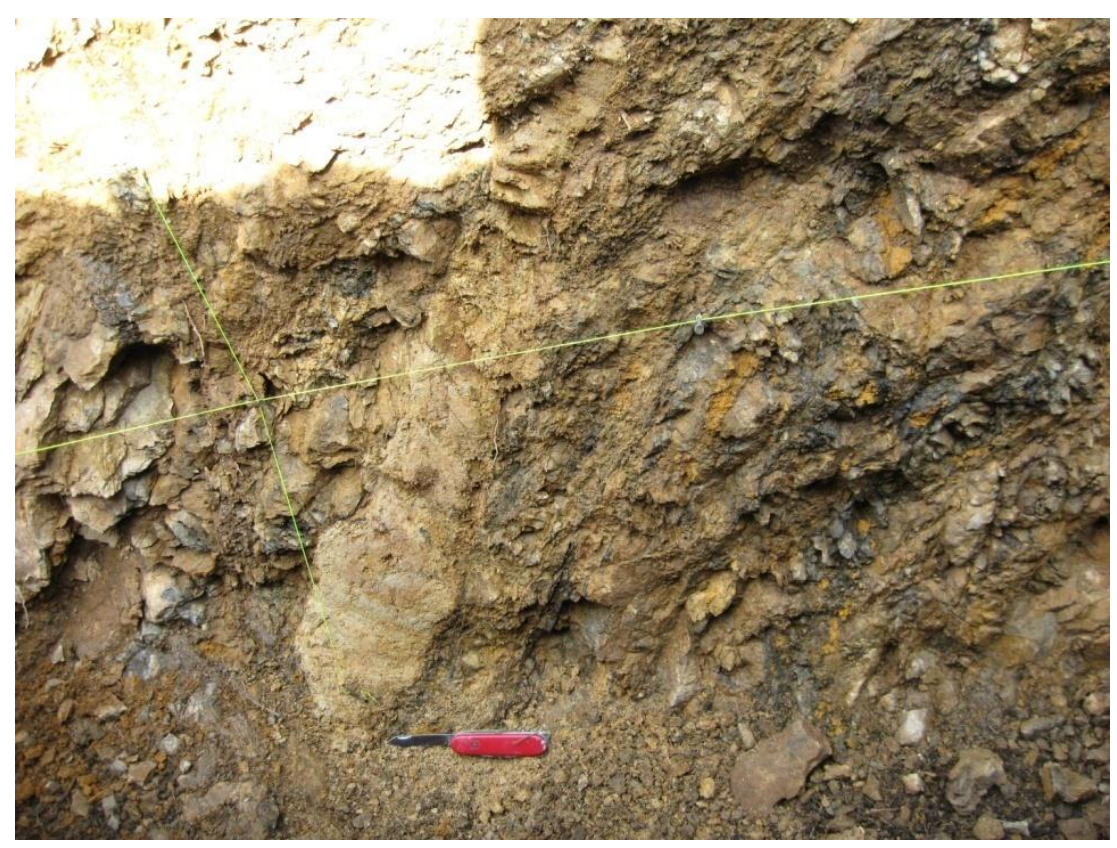

Figure 3-64. Example of intrusive sandstone dike observed in cherts of the Claremont Formation

Figure 3-65 illustrates the overall trench logging of NUMO TR3, showing the main geologic features. The cherts were moderately to strongly weathered and highly fractured. The bedding was obscured by intense fracturing and sandstone dikes. See Kiho et al (2009) for more detail. 


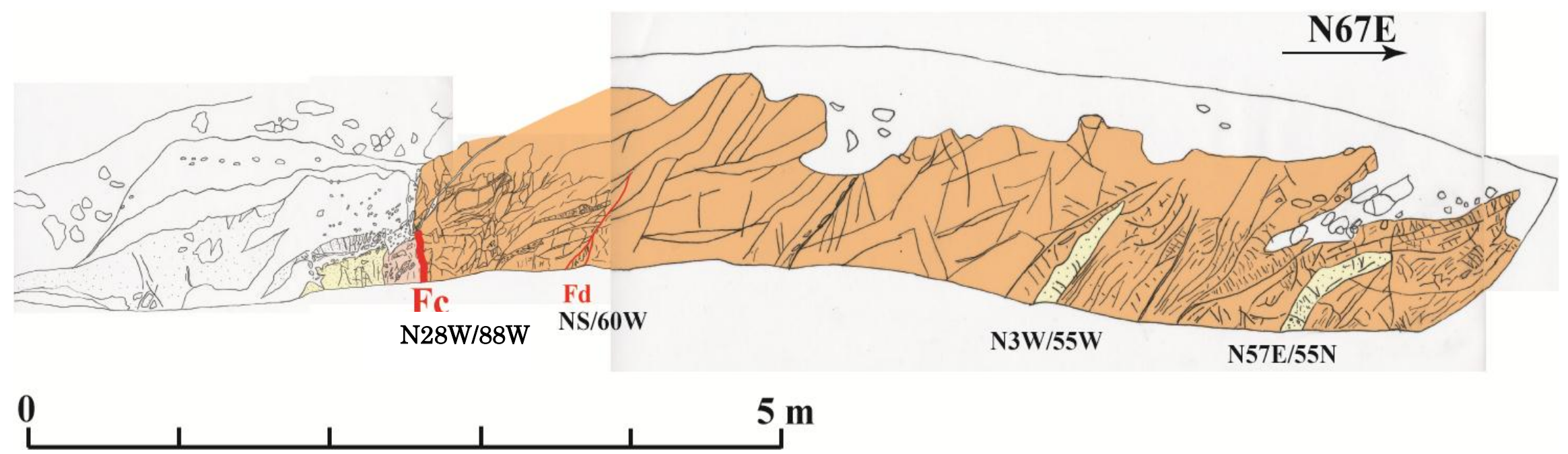

Figure 3-65. Sketch of Trench NUMO TR3, showing the main fault contact between siltstone in the west and the cherts in the east. 


\subsubsection{Summary}

We summarize the findings from the surface geologic survey and the trench studies of the Wildcat Fault its surrounding geology discussed in the previous sections.

- Fault Trace -The trace of the Wildcat fault between Grizzly Peak in the northwest and Panoramic Way and the Fire Trail in the southeast is unclear in aero-photography, owing to a lack of geomorphologic evidence. In addition, the area is highly developed, has poor rock exposure, and a complex stratigraphy including a thick sequence of landslide and colluvium. The geologic map compiled in this report is based on data from previous studies (Untermann, 1935; HLA, 1980; Kleinfelder, 2001; Gilpin, 1994; Graymer, 2000; LBNL and Parsons, 2000; WLA, 2008), and data from field and NUMO trenches. Along Panoramic Way, the fault trace is clear near the Sugar Loaf saddle, and an interesting mixing of Orinda and Claremont rock are observed to the southwest, suggesting that the fault is not composed of one single plane but rather of several shear planes.

- Fault Type-HLA (1980) found vertical slickensides in Trench A, while horizontal slickensides were reported by Untermann (1935) and observed along Panoramic Way (this report). Jones and Curtis (1991 degrees) suggested a thrusting movement along the western side of the Wildcat Fault and Curtis reported lateral movement of about $9 \mathrm{~km}$, based on displacement of volcanic rock. These evidences indicate that the fault has (1) a complex history of fault reactivation along pre-existing faults and/or splays; (2) a reverse component in addition to the strike-slip, which is common in strike-slip systems; and (3) a varying character along its length due to the heterogeneous crust.

- Fault Dip - Previous study of the Wildcat fault outside the LBNL property find faults striking northwest and dipping step to southwest (Untermann, 1935; Graham et al., 1984) to vertical (HLA, 1980, Trench A). However, the fault reported within the LBNL property (LBNL and Parson, 2000, WLA, 2008; and NUMO trenches) has a shallower dip $\left(20-40^{\circ}\right)$ and are coincidently all dipping to the northeast. The change not only in the dip angle but dip direction may be related to gravitational forces, since landslides are common features near the location where the faults were observed. This process could be responsible for changing the dip of the fault as a result of a drag fault. One other explanation for 
the lower dip could be low-angle fault reactivation, possibly related to the fact that the Berkeley Hills have been uplifting due to a change to transpressional regime since 3.6 Ma (Atwater, 1989; Sloan and Karachewski, 2006). WLA (2008) suggests the flower structure as a possible explanation for the low dip of the fault.

- Fault Contact-Faults were mapped in all NUMO trenches. In TR1, the fault is a contact between cherts of the Claremont and siltstones of the Orinda formations. In TR2, the main fault is observed as a contact between the fine sandstone, possibly of Claremont or Sobrante formations and intercalation of siltstone and dark-red mudstone of the Orinda Formation. In TR3, a clear fault contact is observed between cherts from the Claremont Formation and siltstone/mudstone of the Orinda Formation. Gouge zones were observed in all faults.

- Fault Internal Structure-The range of deformation observed from trench studies clearly shows ductile deformation concentrated in siltstone and mudstone of the Orinda Formation showing shear bands, R and P Riedel shear, S-C structure in TR2, gouge in TR1, TR2, and TR3, and fault breccia in TR1. Conversely, the deformation observed in the sandstone is focused in vertical black seams and in highly fractured cherts and siliceous siltstone, with a wide range of fracture spacing resulting from brittle deformation. Therefore, the contrast in material physical and mechanical properties is distinct between the two main formations.

- Geologic Map-A geologic map was compiled based on previous work from geotechnical and geological data, field observations, and trenching. At the scale of the map, the Wildcat Fault is shown as a singular trace in the LNBL property. However, it is known that small faults occur laterally within a short distance, as splay faults. In the south, along the Fire Trail and Panoramic Way, topographic and field evidence (such as slickensides, fracturing, and lithological contacts) indicate that the fault splays in several branches. Based on the location of the fault exposure and additional fault location from previous work (LBNL and Parsons, 2000; HLA, 1980; WLA, 2008), faults and geologic contact were traced as shown in the geologic map (Figure 3-79).

- Conceptual Model-The conceptual model for the Wildcat Fault was built by analyzing the geometry of faults observed in trenches and by evaluating fault 
descriptions from previous work. As illustrated by Graymer (2000), the Wildcat Fault is one branch in the flower structure of the Hayward Fault system. At the scale of field and trench studies, several small branches of the flower structure might be present. Two illustrations demonstrate the conceptual model for the Wildcat Fault - one in the south along the ridge by Panoramic Way, and the other representing the trench locations on LBNL property. The model along Panoramic Way suggests several fault splays apart couple of meters to hundreds of meters (from field observation and topographic features). Faulting features included (a) saddle at the Sugar Loaf ridge, (b) shear planes with slickensides in chert, and (c) highly fractured chert in contact with mixing material. The LBNL model captures trenches NUMO TR1, TR2, and TR3. The colluvium/landsllide deposit might be responsible for producing a low angle dip (i.e., drag fold), observed in trenches TR1 and TR2 and in trenches T2 and T3 of WLA (2008), while trench TR3 might represent a deeper portion of the fault not affected by gravitational sliding/creeping process.

\subsubsection{Discussions and Lessons Learned}

1. Geological investigation and trenching studies provide hands-on and direct assessment of the complexity of a fault.

2. In this exercise, a known strike-slip fault cutting through sedimentary rock was chosen. Although there have been a number of geotechnical investigations conducted in the study area from surface and subsurface surveys, dating back to the 1970s, the geology of the region is still not well understood. The stratigraphy is disrupted by the initiation of the strike-slip fault and uplift of the region. Posterior landslide and colluvium material has changed the topography and geomorphology. Site characterization in Japan would face similar challenges, because Japan is tectonically active, and past fault activity had modified the landscape.

3. Choosing the locations for trenching were time consuming. Knowing the local geology is crucial for projecting any structure, especially faults, to the surface. In the case of no surface exposure, previous work in the area and additional field survey are required to identify such features. Trench locations were chosen depending on terrain condition. 
4. In this study we were able to find a fault plane in all three trenches. At the scale of geologic map they were linked; however, lithologic variations occur along the locations where the fault was observed. The fault is a complex structure when looked at a trench scale. One example of how fault material varies within a short distance is shown in trenches NUMO TR2 and TR3. Those trenches are only about $130 \mathrm{~m}$ apart, but within that distance the fault's character changes dramatically. Not only does the fault contact change, but also the dip of the fault. It is possible that lithological variations might be responsible for changing fault geometry. This is an especially complex issue when dealing with sedimentary rock such as in the Berkeley Hills, where lateral lithological variation is large.

5. At the scale of this study, the trace of the Wildcat Fault is not linear; fault splays are expected to occur and to merge with the main trace. The faults cuts through sandstone and siltstone; cherts and siltstone; and chert and chert. Although many geologic maps only show the main fault trace, fault splays are also important in identifying and better understanding the entire fault system — and improving the conceptual model.

6. This study shows that fault dip and dip direction can change due to gravitational forces associated with landslides, tectonic uplift, and fault reactivation. These would be important aspects to take into consideration during site assessment.

7. The conceptual model illustrates the presence of a flower structure in the study area. Fault splays are likely to occur at any scale, and their distribution on planes and cross sections are likely to be complex. Bedrock of the Orinda Formation would be imprinted by a ductile deformation, while folded cherts of the Claremont Formation by a fracture network. This distinct mechanical property would directly impact the hydrologic properties of the rock.

8. As mentioned in the report "Development of Hydrologic Characterization Technology of Fault Zones," faults cutting sedimentary rock would produce deformation bands, clay smear, and gouges. Those are considered sealing features. Gouges and dark seams were clearly observed within fault zones in trenches NUMO TR2 and TR3, suggesting that the Wildcat Fault would be a barrier to the flow, based on surface geology only. 


\subsubsection{Structural analysis of faults}

木方他(2009)は LBNL に於いて掘削された 3 つのトレンチ(NUMO-TR1, NUMO-TR2, NUMO-TR3)においてマッピングを行い、それぞれのトレンチで観測された断層の構造解析 を行っている。以下は木方他(2009)からの要約である。

\subsubsection{NUMO-TR1}

木方他(2009)は TR1 で観測された基盤岩類は, 断層形成直後の状態を保持おらず、ブロッ ク化している可能性があるとして、観察結果のみを示し，Wildcat 断層に関わるより広域の 地質構造ついての議論は控えている。Figure 3-66 に北西側壁面のスケッチを示す。

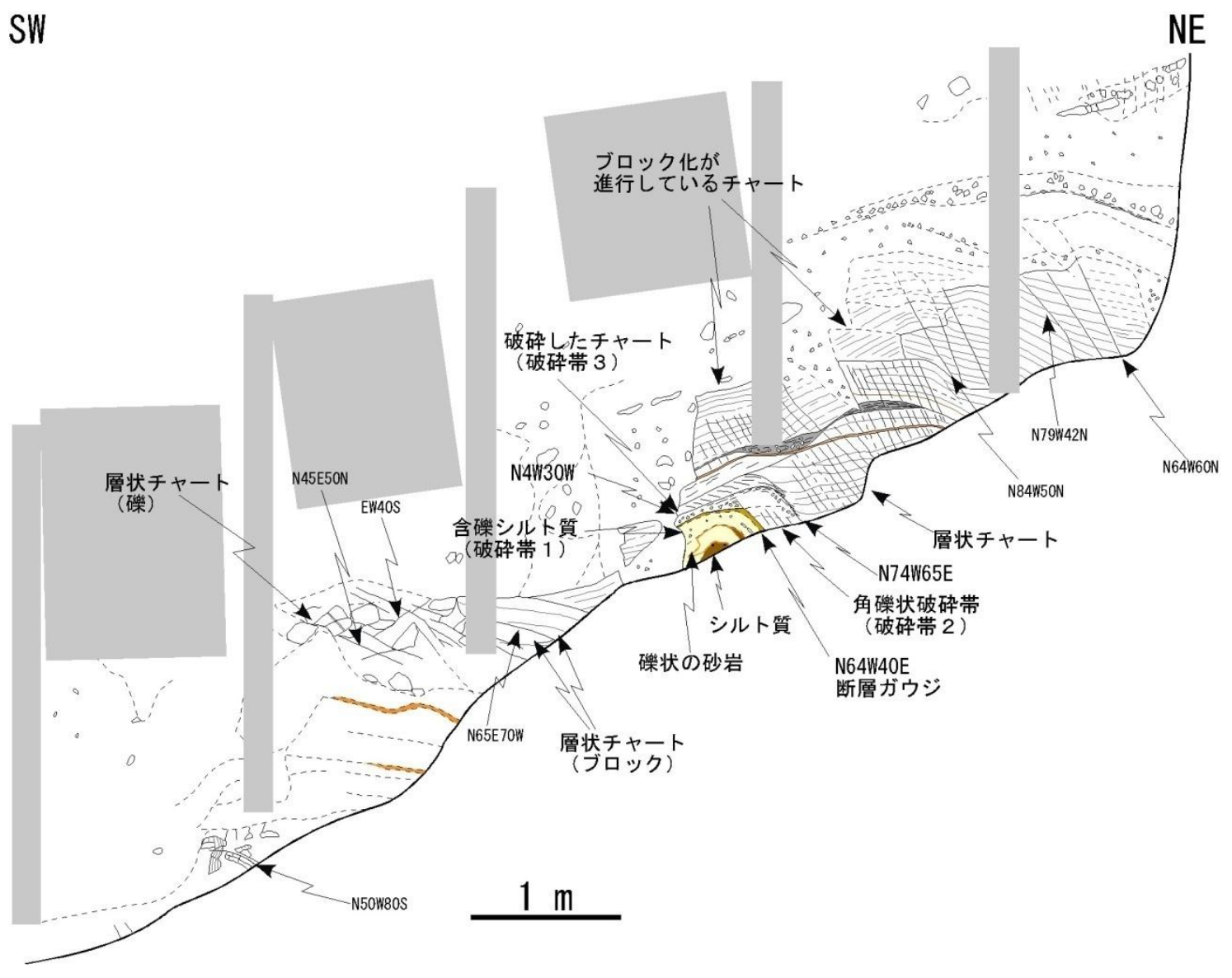

Figure 3-66. Sketch of the north face of NUMO-TR1 
Figure 3-67 に木方他(2009)が確認した断層の写真を示す。TR1 では Claremont 層が砂岩層 （おそらくSan Pablo 層群）の上盤側に断層関係で分布することを確認している。この断層 の走向傾斜は，TR3 で確認した Wildcat Fault Zone の走向傾斜（N30W40E，N17W40E）と， 空中写真判読から想定されるWildcat 断層の走向とは明らかに斜交するとしている。断層部 は南西から，(1)礫状の砂岩，(2)破砕帯 1, (3)断層ガウジ，(4)破砕帯 2 , (5)破砕帯 3 により 構成されている。以下はそれぞれの部分の木方他(2009)の観察の要約である。

(1)碩状の砂岩は，炭質物を含む細粒砂岩であり，トレンチ-3 で確認した断層の西側に分 布する砂岩層と同様であり，San Pablo 層群の砂岩に相当すると考えられるが、下記の断層 破砕帯中にシート状に取り込まれブロックの可能性がある。

(2)破砕帯 1 は磎状砂岩を囲むように幅 $10 \mathrm{~cm}$ 程度で分布し，シルト質な基質中にチャート 等の角硆を含む。破砕による細粒化，角碟化を被っていると考えられる。その境界に酸化 による褐色バンドが認められる。

破砕帯 1 の上盤側には，幅 $1 \mathrm{~cm}$ 程度の粘土が存在し，(3)断層ガウジの可能性がある。こ の粘土層の連続は不明瞭で粘土質部が存在する。

(4)破砕帯 2 は，幅 $20 \mathrm{~cm}$ 程度の角硆状破砕帯である。角磎は，硬質で細粒な砂質岩が含ま れる。上位の緩傾斜になるところは，より軟質で砂質な基質中に砂岩が礫状に含まれてい る。

(5)破砕帯 3 は, 破砕したチャート層であり, 破砕帯 2 の上位に幅 $5 \mathrm{~cm}$ 程度で分布し, 破 砕帯 2 と N74W65E で接する層状チャートにおいても接触面から $20 \mathrm{~cm}$ 程度は破砕質である。 さらに北東側のチャート層は幅 $1 \mathrm{~m}$ 以上にわたり，ほぼ東西〜西北西走向の割れ目が卓越寸 るゾーンが存在する。この割れ目発達ゾーンは断層に伴うダメージゾーンの可能性がある。 


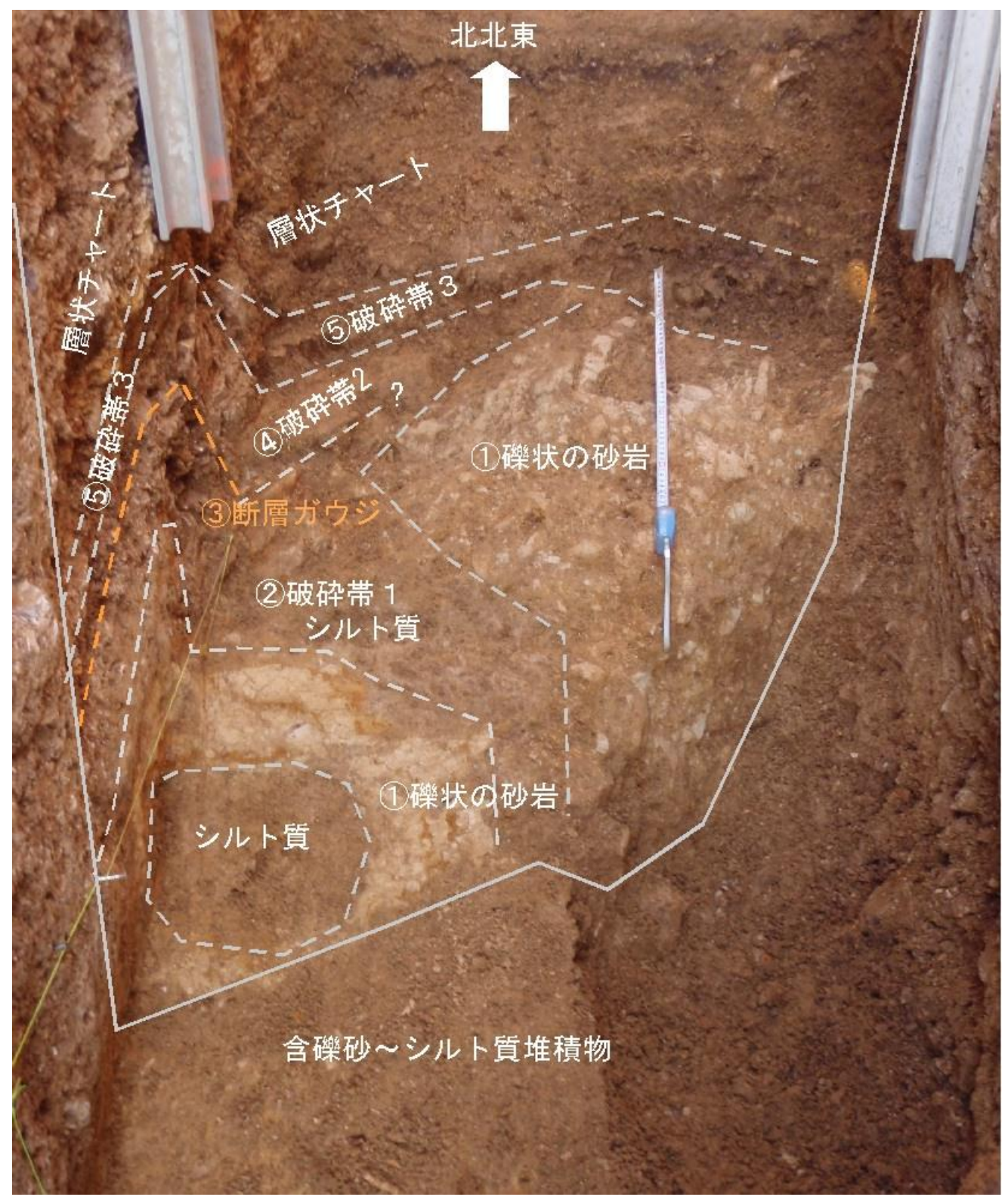

Figure 3-67. Picture of the exposed fault in NUMO-TR1. The solid line is the boundary between the bedrock and the alluvium and the broken lines show estimated boundary of the fault rock. 


\subsubsection{NUMO-TR2}

\subsection{Fault Fracture Zone and Surrounding Deformation Structure}

木方他(2009)は NUMO-TR2 において San Pablo 層に相当する砂岩と Orinda 層に相当する 泥岩の境界（Fa 断層）と， Orinda 層に相当する泥岩内に（Fb 断層）2つの断層を確認して いる（Figure 3-68）。以下は木方他(2009)の観察の要約である。

a. $\mathrm{Fa}$ 断層および周辺

Fa 断層（Figure 3-69)は連続性の良い赤褐色の断層ガウジ（幅 $5 \mathrm{~mm}$ ）を伴い、ブロック サンプル E（Figure 3-70）のC T画像においても観察できている（Figure 3-71）。Fa-1 断層 面の下盤側は Orinda 層の泥岩・砂岩起源の断層岩（幅約 $60 \mathrm{c} \mathrm{m}$ ）が分布し、全体に鱗片状 へき開が発達し，細粒砂岩のレンズ化が進行している。細粒砂岩のレンズや tail の伸びの方 向とこれらを切るせん断面とからなる葉片状カタクレーサイトと呼ぶ複合面構造が顕著に 発達している。

トレンチ北壁面における複合面構造から, Fa 断層の逆断層変位が推定される。すなわち, 中期〜後期中新世の San Pablo 層相当の砂岩が，後期中新世の Orinda 層相当の泥岩主体の層 に衝上したと考えられる。またトレンチ東壁面および底面における顕著な複合面構造から， $\mathrm{Fa}$ 断層の右横ずれ変位が推定される。以上の複合面構造は, トレンチ北壁面よりトレンチ 東壁面および底面の方が顕著に発達することから，Fa 断層は斜めずれ断層であるものの， 右横ずれ変位成分の方が逆断層変位成分より卓越するものと推定される。

Fa-1 断層（主断層）面の上盤側には幅約 $3 \mathrm{~cm}$ の断層ガウジ帯が認められ，採取したブロ ックサンプルにおいては，断層の上盤側に位置する砂岩起源の細䃯を伴う。この断層ガウ ジは上盤側の砂岩の割れ目に注入しており，過去の断層運動に伴う流体移動が推定される。 また割れ目沿いに砂岩の白色化が認められ, 流体移動に伴う変質作用も考えられる。砂岩 内の割れ目は断層から少なくとも $1 \mathrm{~m}$ 離れた範囲まで顕著に発達し、C T画像によるとネッ トワーク状に発達している様子を観察することができる。

\section{b. Fb 断層および周辺}

$\mathrm{Fb}$ 断層は主断層面（Fb-1） と副次的な断層（Fb-2,3）からなる。両断層は地下で収れんす る可能性が考えられる。Fa 断層と同様，幅約 $70 \mathrm{c} \mathrm{m}$ の葉片状カタクレーサイト帯を伴い, 右横ずれ変位センスを示す複合面構造が観察された。 


\subsection{Predicted Hydrologic Properties}

木方他(2009)によれば、断層ガウジの連続性が良く, 断層に沿って分布する葉片状カタク レーサイト帯も主体が軟質な泥岩起源で顕著な割れ目が発達していないことなどから，主 断層より下盤側は比較的透水性が低いものと推定される。一方，主断層の上盤側の砂岩は 割れ目がネットワーク状に発達し，充填されていない割れ目の存在も推定されることから， 比較的，透水性は高いものと考えられる。

\subsubsection{NUMO-TR3}

\subsection{Fault Fracture Zone and Surrounding Deformation Structure}

木方他(2009)によれば断層はClaremont 層のチャートとSan Pablo 層に相当する砂岩との境 界に認められ（Fc 断層），Wildcat 断層系の主断層と考えられる（Figure 3-72）。断層の走向・ 傾斜は $\mathrm{N} 2^{\circ} \mathrm{W} / 88^{\circ} \mathrm{W}$ で，幅の変化が著しい角礫混じりの粘土帯を伴う。ブロックサンプ ルの切断面の観察やC T解析によると, 角碩混じりの粘土帯において, 右横ずれ変位を示 す引きずり構造が顕著に認められる。断層ガウジは断層面に沿って部分的に数 $\mathrm{m} m$ の幅で 観察される程度である。

TR-3 では多くの節理面・せん断面が発達し，チャート層のレンズ化・ブロック化が進行 し, 細礫状に破砕されているゾーンも認められる。チャート層内に分布する中〜粗粒砂岩 については，級化構造が認められないこと，上方へ向かい膨縮しながらせん滅することな どから，未固結時に貫入した砂岩ダイクの可能性が考えられる。この砂岩の起源について は, 断層に接して西側に分布する San Pablo 層の砂岩が, 可能性のひとつとして考えられる。 この砂岩ダイク周辺においてはチャート層の破砕が著しい傾向にあり，砂岩の貫入に伴う チャートの破砕も推定される.

\subsection{Predicted Hydrologic Properties}

木方他(2009)によれば、TR-3 で観察された Wildcat 断層の主断層（Fc 断層）は，角礫混じ り粘土化帯を伴うものの，膨縮が著しく，断層ガウジも連続性に乏しいことから，TR-2 の $\mathrm{Fa}, \mathrm{Fb}$ 断層に比べれば透水性は高いと考えられる。主断層の西側に分布する砂岩 (San Pablo 層）は節理面が発達しブロック化が進行しており，透水性は比較的高いものと推定される。 主断層の東側に分布するチャート層（Claremont 層）は，元来，硬質な岩石であるが，断層 近傍では割れ目が発達し開口も顕著であることから，透水性は高いものと推定される. 


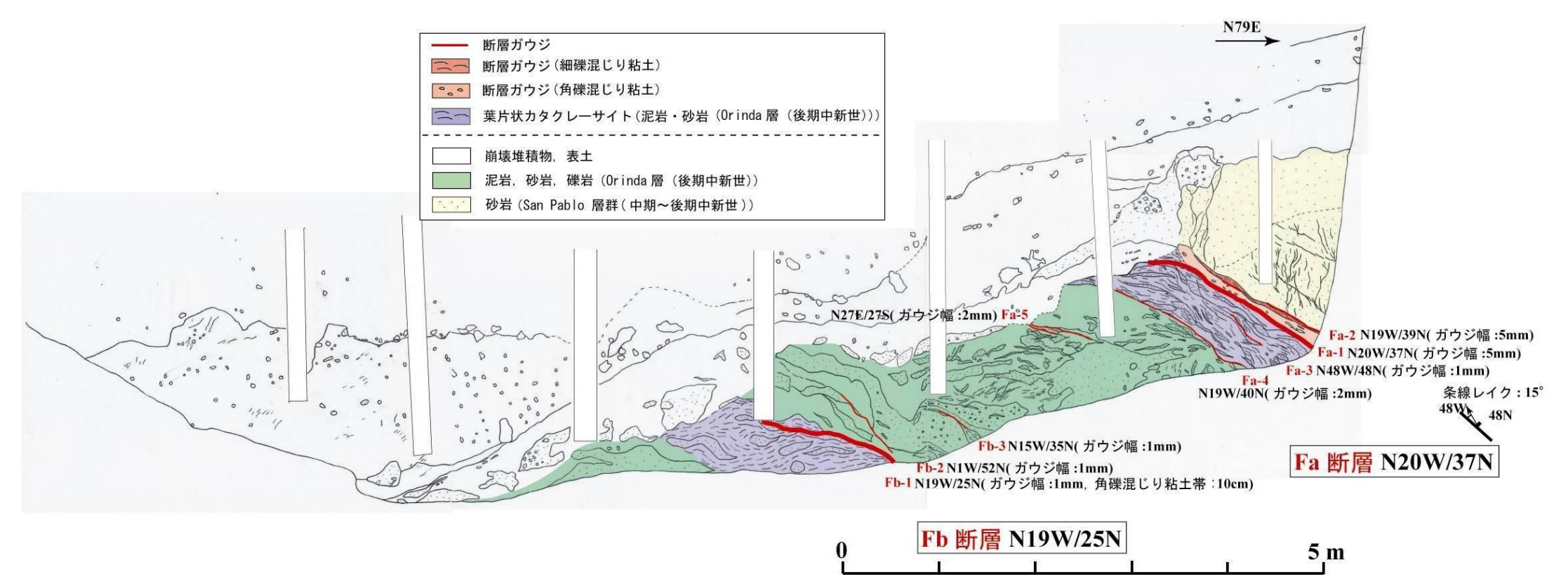

Figure 3-68. Sketch of the north wall of NUMO-TR2. (Kiho et al, 2009) 


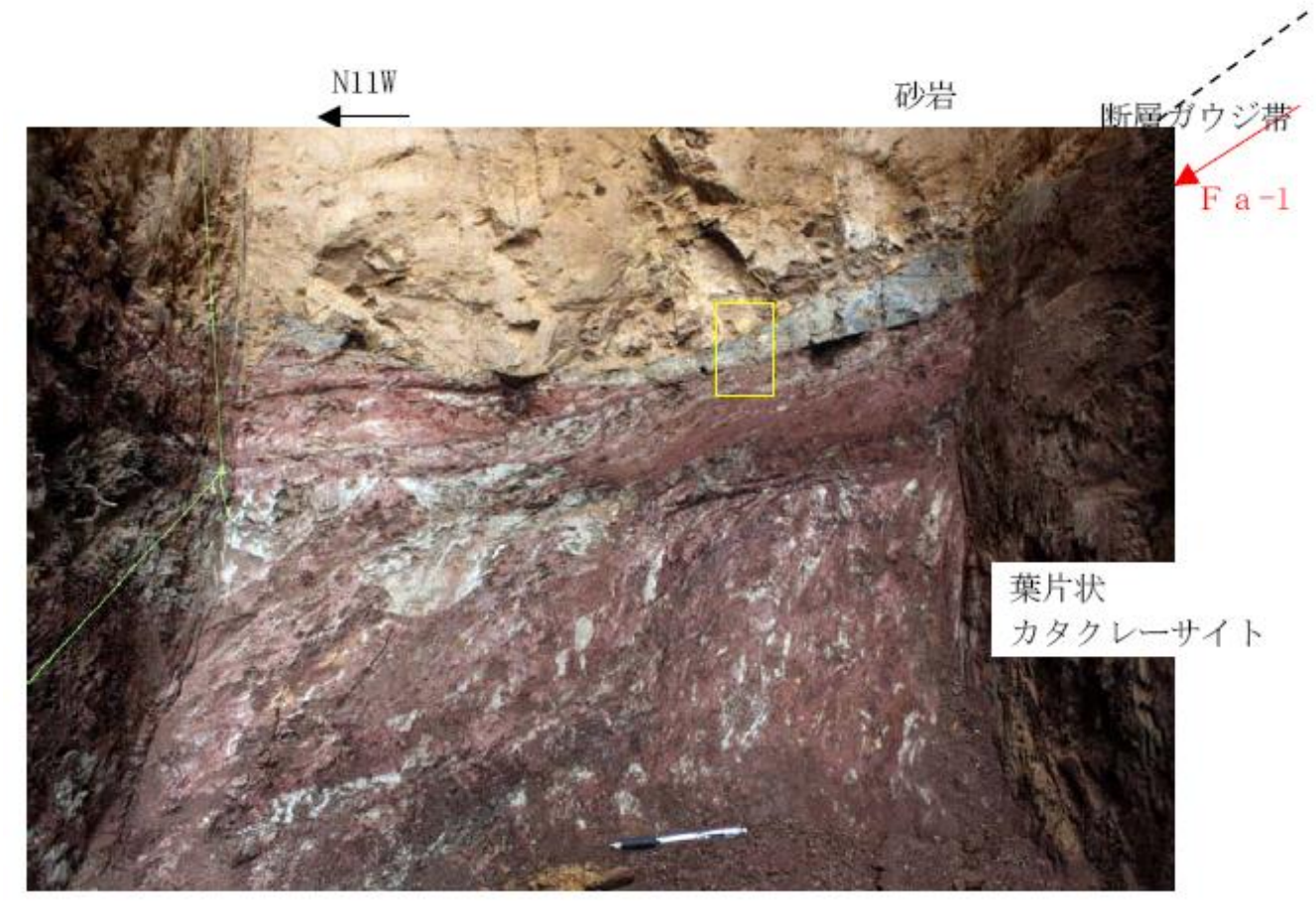

Figure 3-69. East and bottom wall of NUMO-TR2. Yellow box shows the location Block Sample E was taken. (Kiho et al, 2009)

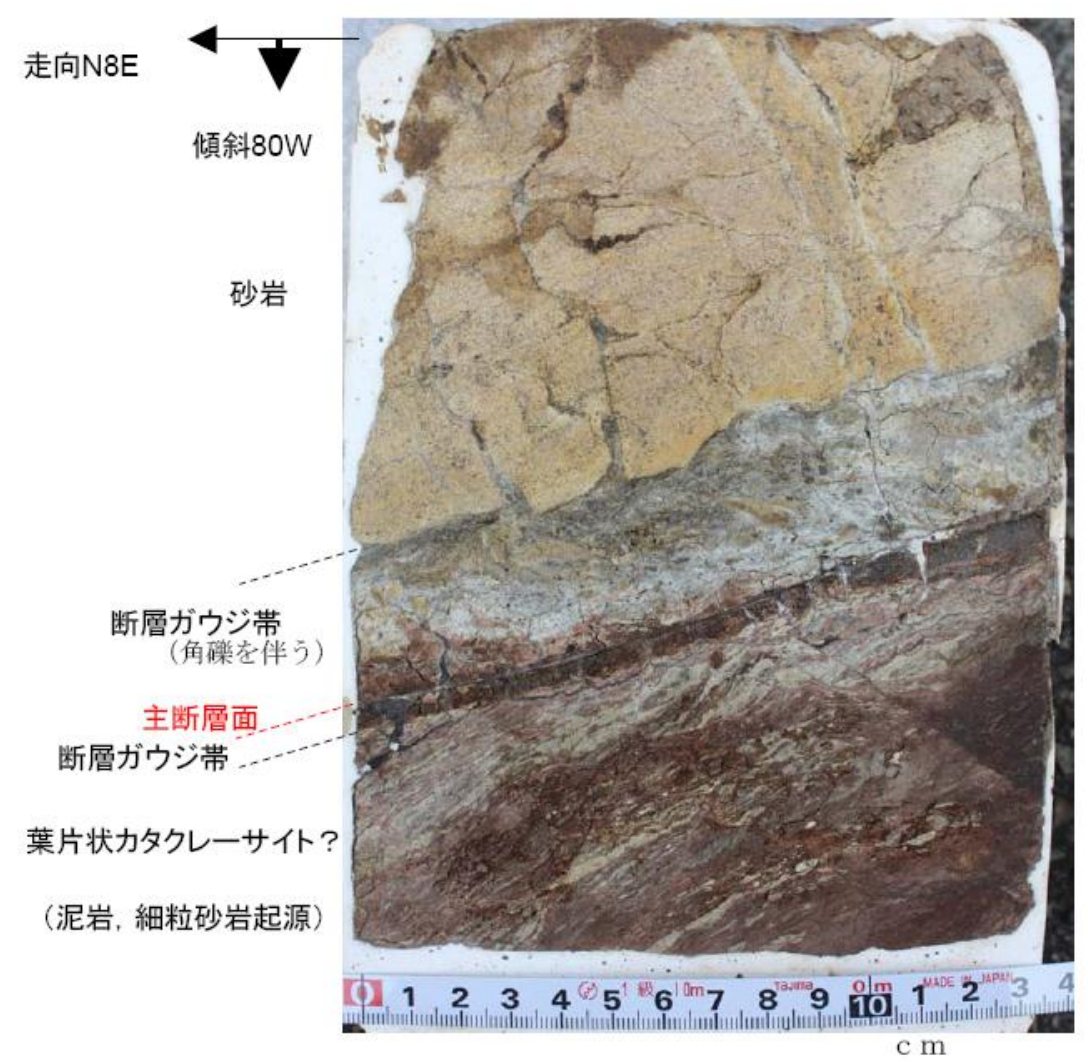

Figure 3-70. Block Sample E showing the details of Fa-1. (Kiho et al, 2009) 


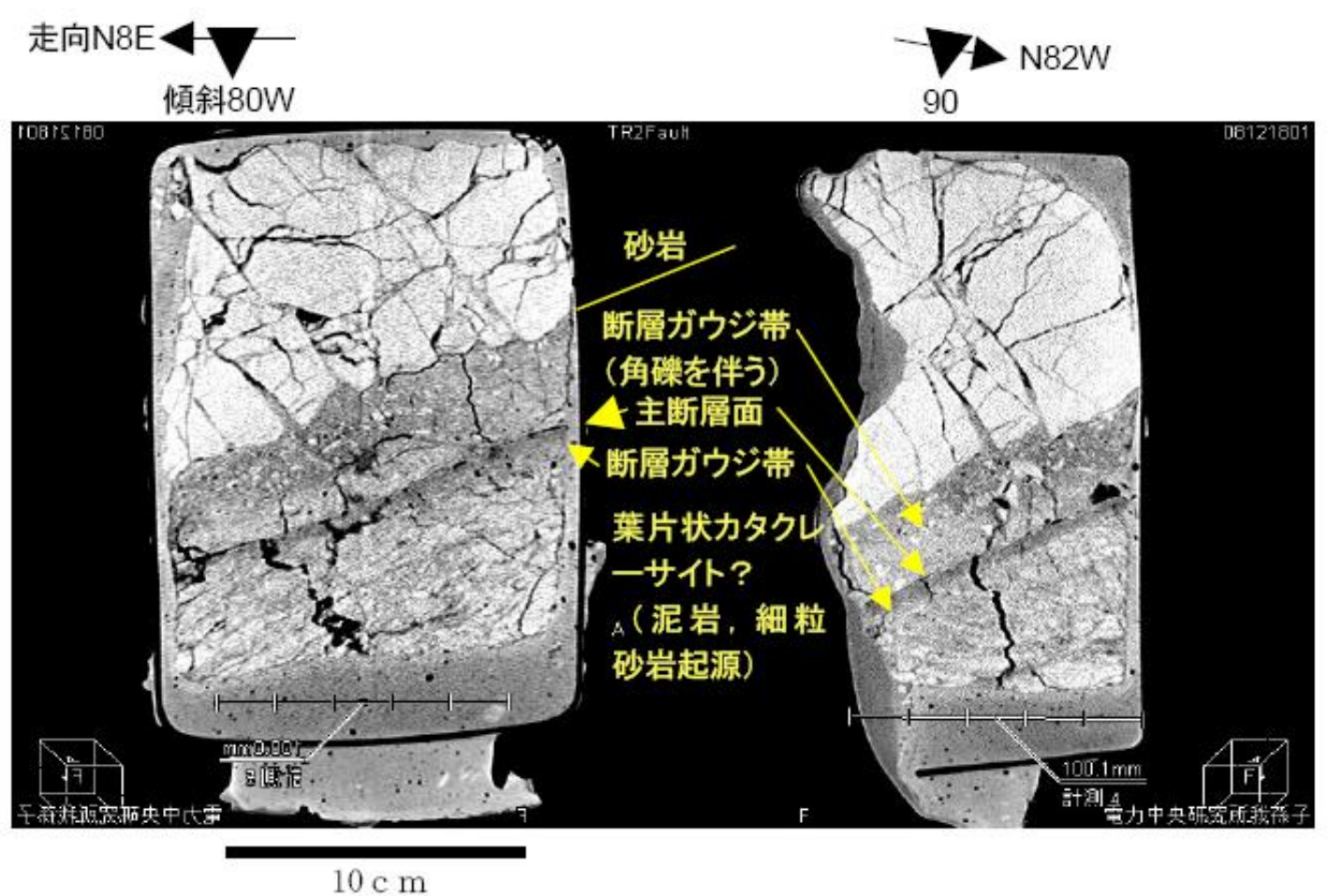

Figure 3-71. Cross sectional views of Block Sample E by CT scanner. (Kiho et al, 2009) 


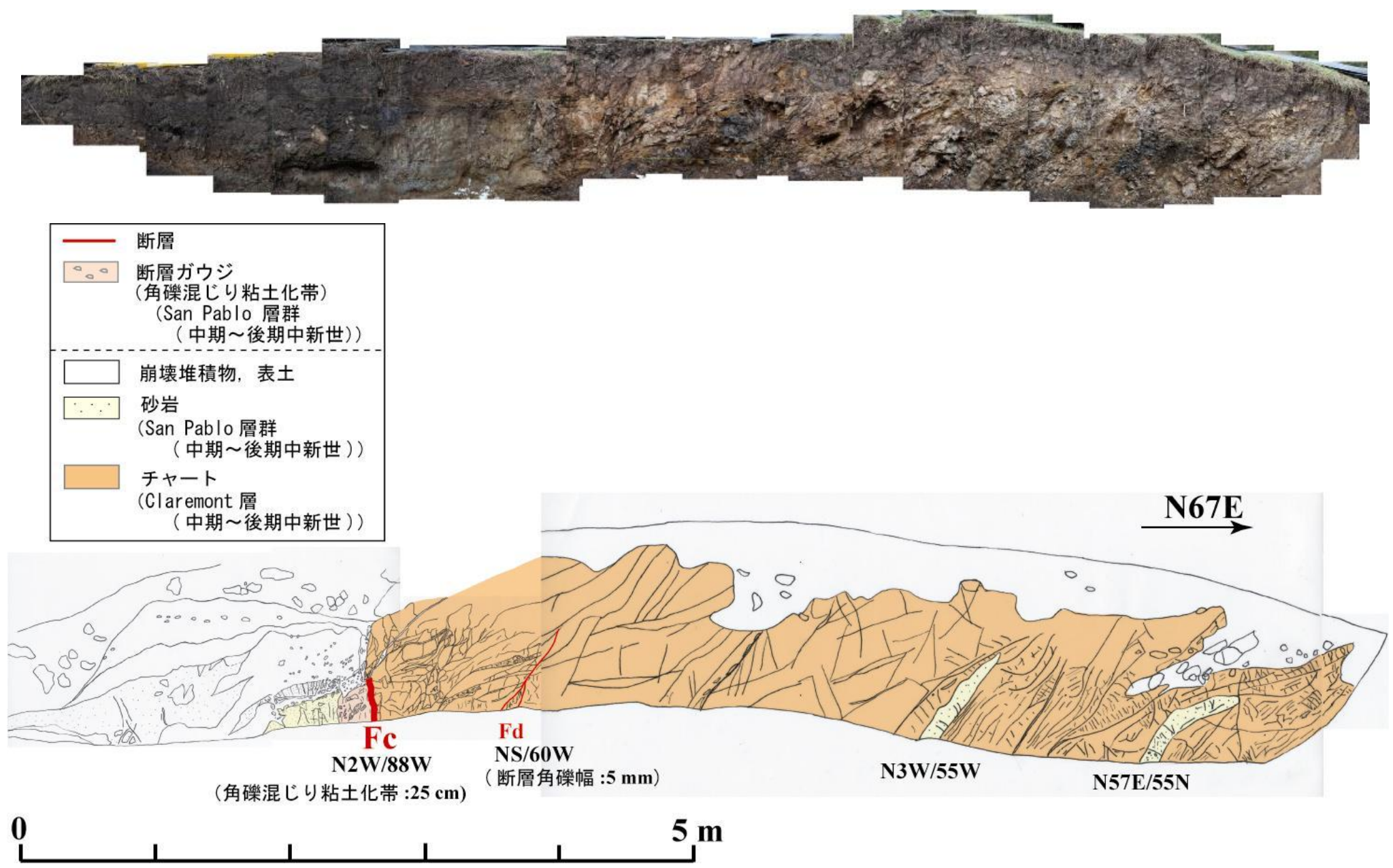

Figure 3-72. Photo and sketch of the north face of NUMO-TR3. (Kiho et al, 2009) 


\subsection{Analysis and evaluation of results}

\subsubsection{Conceptual Model}

\subsubsection{Conceptual model by Kiho et al.(2009)}

木方他(2009)は 3.1.2.1.3 章で要約した断層構造解析の結果に基づき, LBNL 敷地周辺に おける Wildcat 断層の北部区間と南部区間を対象に, 地質構造モデル(試案)を予察的に作成 している（Figure 3-73）。

\section{a. Northern Section}

木方他(2009)によれば、北部区間では Wildcat 断層周辺において、Claremont 層（チャート 主体）, San Pablo 層群（砂岩主体）, Orinda 層（泥岩主体）が分布する。San Pablo 層群（砂 岩主体）と Orinda 層（泥岩主体）の境界には，低角度の断層（ $\mathrm{Fa}, \mathrm{Fb}$ 断層）が存在する。 Claremont 層（チャート主体）と San Pablo 層群（砂岩主体）の境界には，TR3で見られた ほぼ鉛直の断層（Fc 断層）が存在する。両断層は，地下深部で収れんするフラワー構造と して推定している。低角度の断層（Fa,Fb 断層）は連続性の良い断層ガウジと葉片状カタク レーサイトを伴うことから，透水性は低いと推定される。一方，ほぼ鉛直の断層（Fc 断層） は断層ガウジの連続性が良くないことなどから、透水性は高いと推定している。

木方他(2009)は断層近傍において Orinda 層（泥岩主体）は、ダメージゾーンの幅も狭く透 水性は低いと推定している。San Pablo 層群（砂岩主体）は節理が発達し透水性は比較的高 いと考えている。当層は低角度の断層（ $\mathrm{Fa}, \mathrm{Fb}$ 断層）とほぼ鉛直の断層（ $\mathrm{Fc}$ 断層）に挟まれ 楔状に分布寸る可能性があることから，両断層の影響を被りダメージゾーンの幅は広いも のと推定している。Claremont 層（チャート主体）は断層近傍では割れ目が発達し開口して いる箇所も認められることから，ダメージゾーンの幅は広いと考えた。

\section{b. Southern Section}

木方他(2009)は TR1 では基盤の断層構造を捉えることはできなかったが，Baldwin and Givler（2008）を根拠に、Wildcat 断層を境に東側にClaremont 層（チャート主体），西側に San Pablo 層群（砂岩主体）が分布し，両者の境界に東傾斜の低角度の断層が存在するとし ている。Claremont 層内（チャート主体）には西傾斜の高角度断層が存在し、両断層は地下 深部で収れんすると考えた。これらの断層の透水性に関しては, TR3 の観察結果を参考に, 
断層ガウジの連続性が良くないと予測し、透水性は高いと推定している。また断層近傍に おける Claremont 層（チャート主体），San Pablo 層群（砂岩主体）については，TR3 の観 察結果から，透水性が高く，ダメージゾーンも比較的広いものと考えた。

木方他(2009)は LBNL 敷地の特に北部区間は伸張性のジョグに相当する可能性があると している。伸張性のジョグにおいては，正断層変位成分を有する高角度断層の前面側に， 逆断層変位成分を有する低角度断層が分岐することが知られており, TR2,TR3 の調查結果 に基づく北部区間の断層構造モデルは，これに該当する可能性があるとしている。木方他 (2009)はこのような Wildcat 断層系の右横すれ運動が，San Pablo 層群堆積時にも生じていた とした場合，同層群は伸張性ジョグ部の Pull-apart basin に堆積したため，狭長な分布を示し ていると推定できるとした。さらに San Pablo 層群の砂岩が断層運動により, 未固結な状態 でClaremont 層と接し, 断層変位時の地震動と密接に関連しチャート層に注入して砂岩ダイ クが形成され，チャート層も破砕された可能性も挙げている。またトレンチ-2，3でみられ た断層ガウジの注入やネットワーク状, ジグソーパズル状の割れ目も, 断層変位時に伸張 性ジョグ部で生じるサクションに関連し, 角礫化の進行も hydroulic implosion Breccia の形成 過程を示していると推定している。この伸張性ジョグ部は現在の水理特性に大きな影響を 与えている可能性を指摘している。 


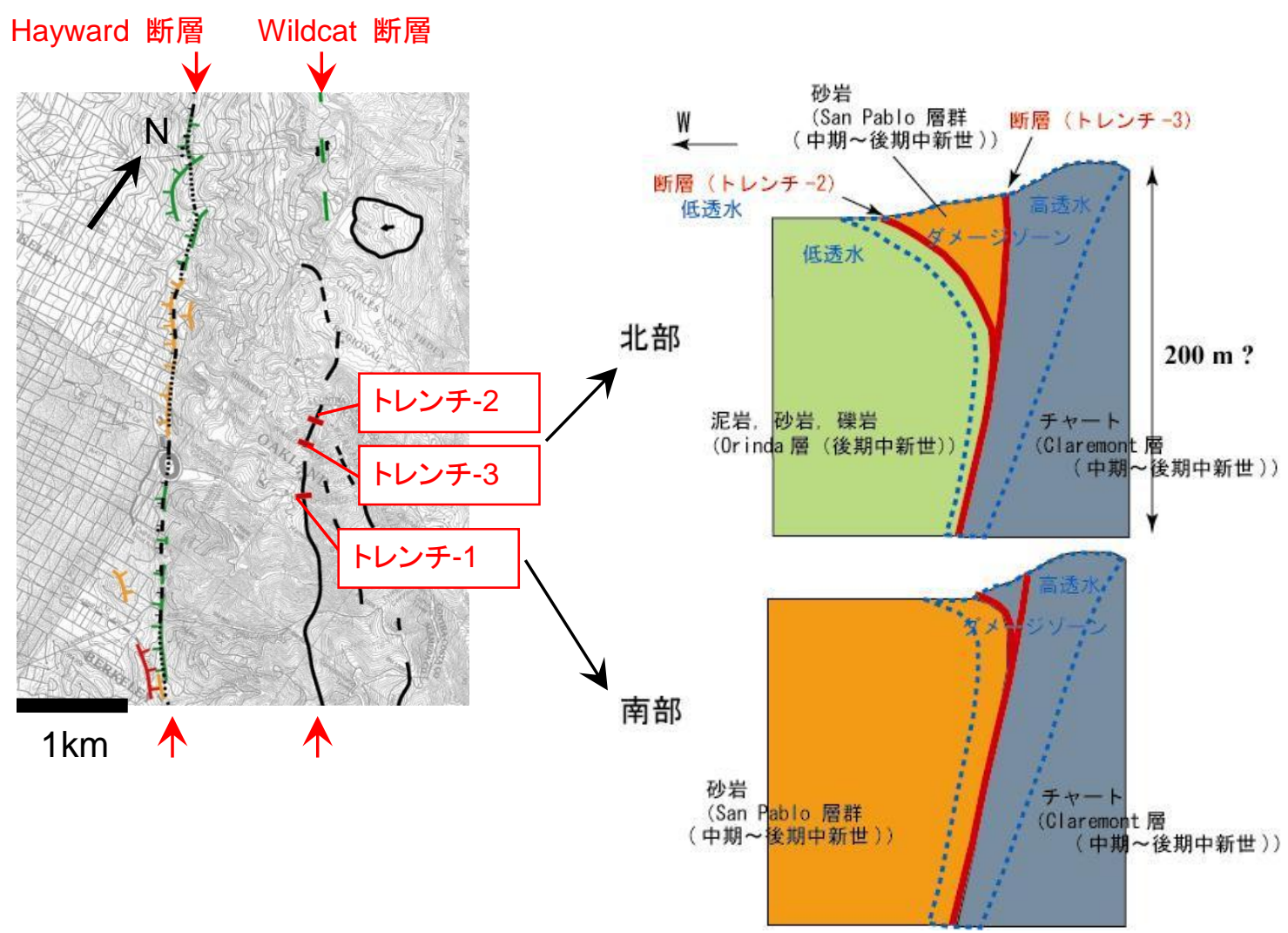

Figure 3-73. Conceptual model of the Wildcat Fault structure by Kiho et al(2009) 


\subsubsection{Conceptual Model by LBNL}

Strike-slip fault systems can result in complex fault geometries in plane view. They include a variety of shear fractures, folds, and normal and thrust faults that are associated with strike-slip faults. Bends and stepovers in the principal displacement zones (PDZ) of a strike-slip fault system generally produce either zones of extension (pull-apart basins) at releasing bends or stepovers (Figure 3-74a), or regions of compression, uplift, or pop-up structures (positive flower structure) at restraining bends or restraining stopovers (Figure 3-74b) (McClay and Bonara, 2001).
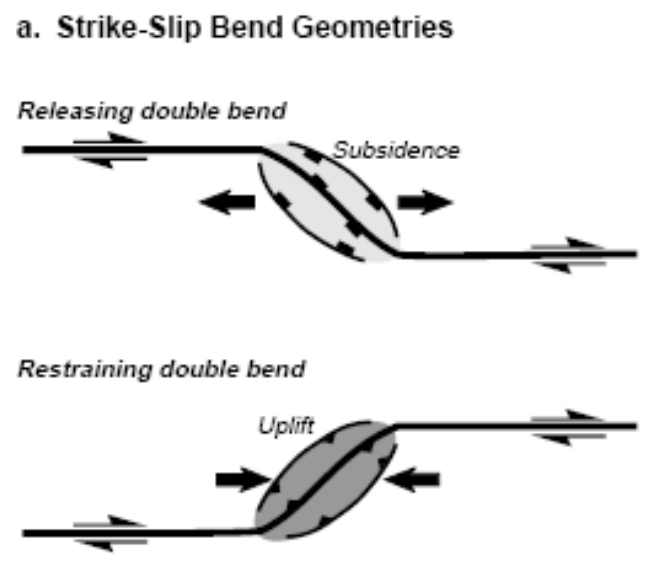

b. Strike-Slip Stepover Geometries
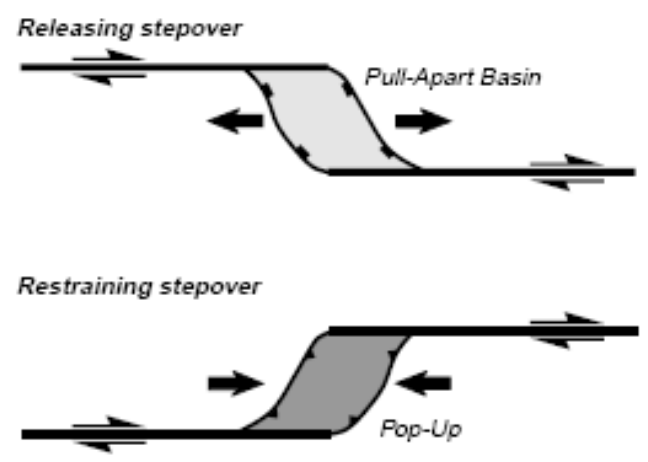

Figure 3-74. General characteristics of strike-slip fault systems in plan view: (a) Bends in the fault surface produce localized zones of extension and subsidence, whereas restraining bends produce localized zones of contraction and uplift; (b) Stepovers between two offset fault systems produce either pull-apart basins for releasing stepovers 
or pop-ups and uplifts for restraining stepovers.

In plane view, a strike-slip fault system has typically a lozenge-to-rhomboidal shape (McClay and Bonara, 2001). As shown in Figure 3-75 geologic and structural complexity increases with deformation due to block rotation, shearing, uplift, and faulting.
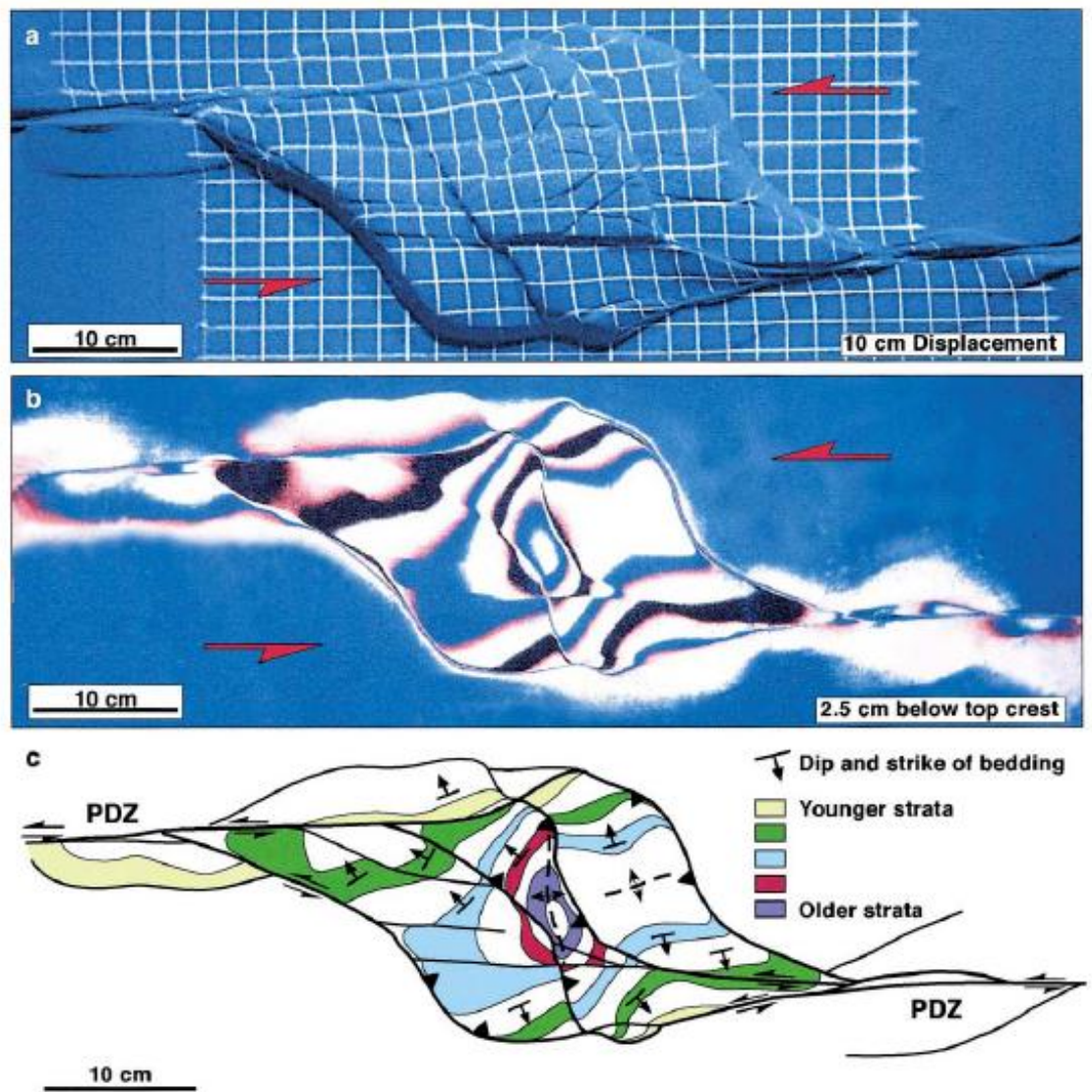

Figure 3-75. Analog model showing the complex structure generated during strike-slip faulting

In cross section, strike-slip faults frequently splay upward into outwardly branching segments that exhibit "flower" (or "palm-tree" or "horse-tail") configurations (Hatcher, Jr., 1974). It is well known that the Hayward Fault displays a positive flower structure as presented in the geologic map of Graymer (2000) (Figure 3-76). In Graymer's interpretation, the Wildcat Fault is a splay of the flower structure in the Cross Section A-A', lying between the Hayward and Moraga faults. The Moraga Fault is a high-angle reverse thrust fault with several hundred meters of slip (Graham et al., 1984). 


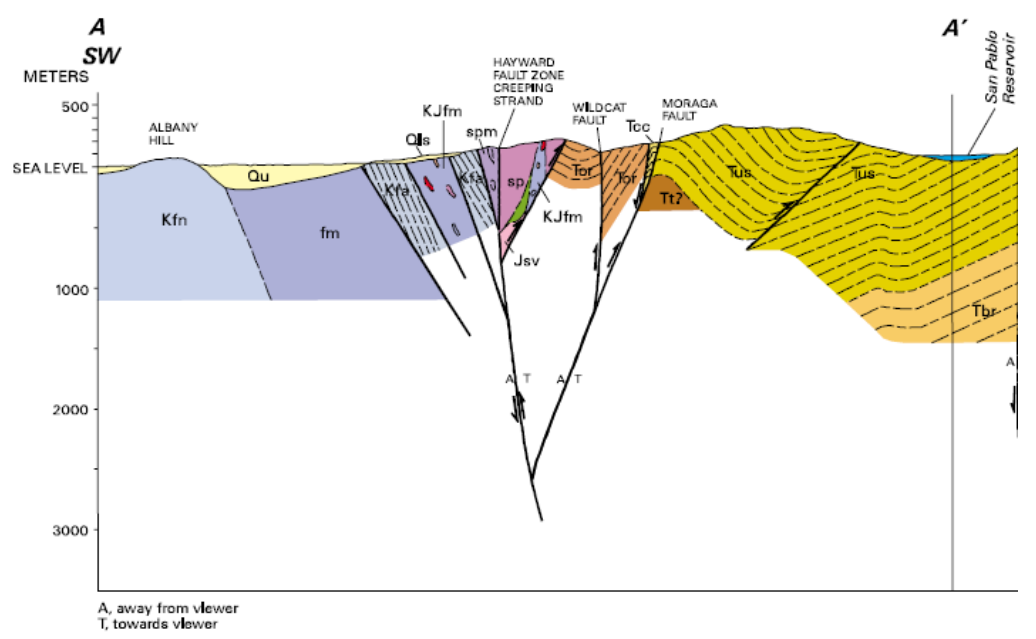

Figure 3-76. Geologic cross section of the East Bay showing the flower structure of the Hayward fault and the relationship with the Wildcat and Moraga faults (Graymer, 2000)

In the study area, two block diagrams illustrate the conceptual model based on data from field and trench studies. Figure 3-77 illustrates the fault interpretation based on fault distribution observed south of the study area at Panoramic Way. Faulted material was observed on samples by the saddle where the main fault plane lies (Untermann, 1935, Graymer, 2000). Fault splays with slickensides in cherts were found in outcrops east and west of the saddle. Narrow shear zones mixing sediments of Orinda and cherts of Claremont formation was exposed on the ground further west, suggesting several fault splays as described in section 3.3.2.2. 


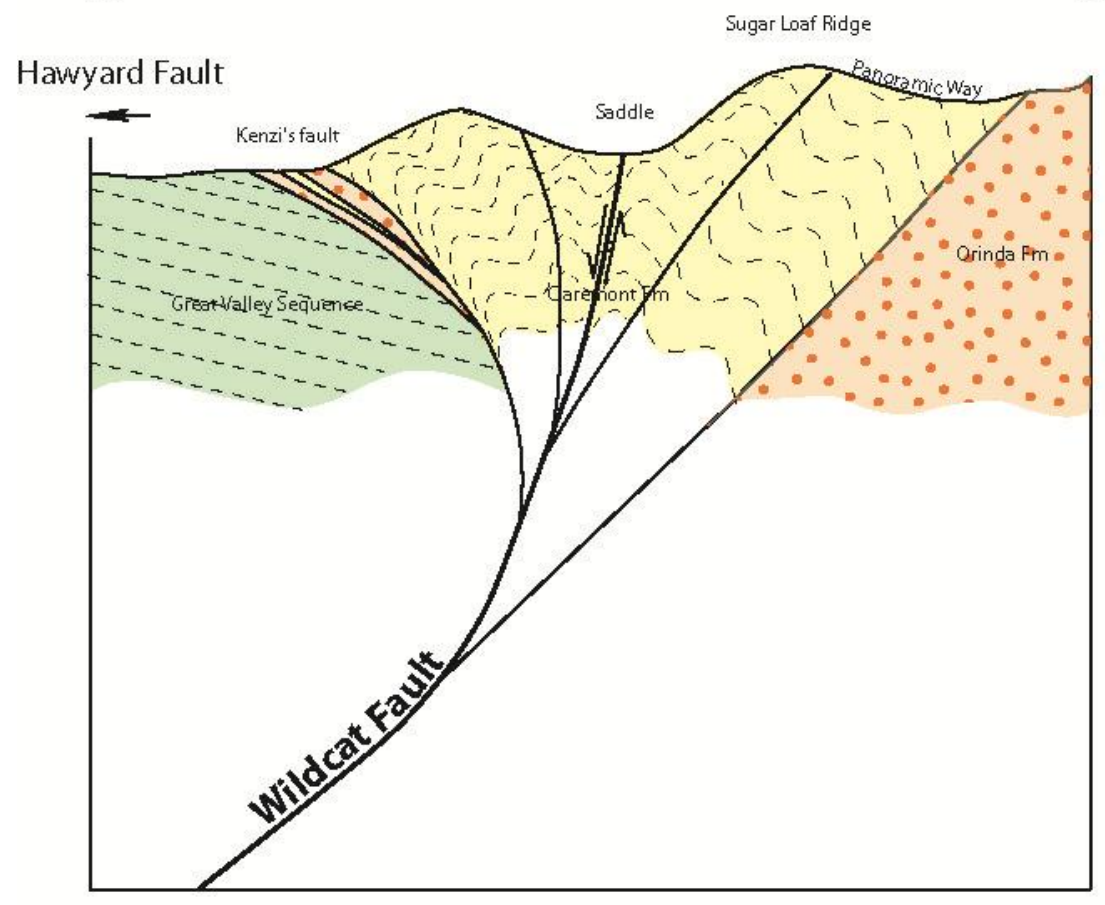

Figure 3-77. Cartoon illustrating fault geometry at depth at Panoramic Way

Trenches within LNBL are located at lower elevations compared to Grizzly Peak or Fire Trail. Because LBNL is surrounded by hills, it is common to have a thick deposit of colluvium/landslide accumulated over the years, described by previous work. Thick colluvium was also confirmed in trench NUMO TR1. The conceptual model for the fault geometry at depth within LBNL property is illustrated in Figure 3-78. It shows the main trace of the Wildcat Fault as the contact between Claremont and Orinda formations. Secondary branches cutting through the Orinda Formation were also observed in NUMO TR2 and described by Jordan (unpublished data) on splay fault near Building 74.

One peculiar fact is that fault dips observed in trenches NUMO TR1, TR2, as well as faults described in Trenches T2 and T3 of WLA (2008) consistently dip at low angles to the northeast. The low dip to the northeast was interpreted by WLA to be part of the flower structure. To the east of the Wildcat Fault, WLA (2008) observed normal faults in cherts and described in trench T1 (WLA, 2008). The evidence of low-dipping faults and normal faults suggest that the fault and fault splays have been rotating, forming drag folds as a result of gravitational sliding/creep. It seems that NUMO TR1 and TR2, along with 
WLA trenches T1, T2, and T3, represent the upper part of a fault that has been affected by surficial processes, as illustrated in Figure 3-78.

As the fault is projected along its length to the northwest towards trench NUMO TR3, the colluvium deposit is almost absent, exposing the bedrock at shallow depth as described in Section 3.3.4.3 NUMO-TR3. The fault is also a clear contact between Orinda and Claremont formations. The fault has a step dip to the southwest, and its orientation suggests that the mapped fault has not been affected by gravitational sliding/creeping. Therefore, as illustrated in Figure 3-78, trench TR3 is interpreted as located relatively deeper than trenches TR1 and TR2.

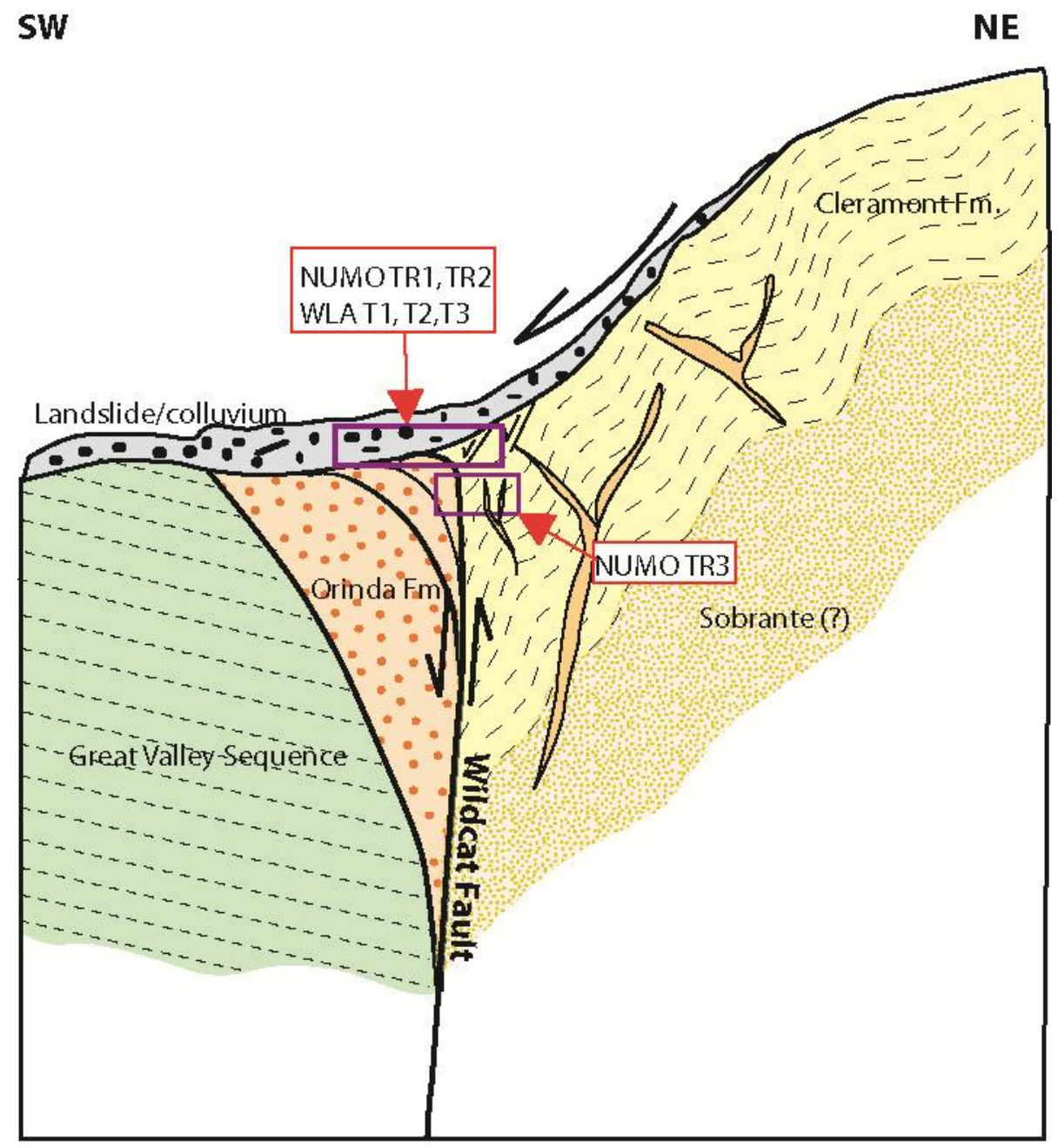

Figure 3-78. Illustration of the conceptual model of faults within LBNL property. The box in red represents trench locations. 


\subsubsection{Geologic Map}

A geologic map was compiled using data from previous studies, field and trench surveys (Figure 3-79). The location of the bedrock is based on rock exposure, trench descriptions, and borehole data. Although some of geotechnical reports state the presence of San Pablo Group near Building 74, the rock description are similar to those from Orinda Formation, therefore, no distinction were made between the two of them and only the Orinda Formation is refer in the geologic map. See Appendix 1 for a larger insert of the map. Note that the scale is in feet. This is due the fact that topographic maps in the USA do not use International System (SI). 


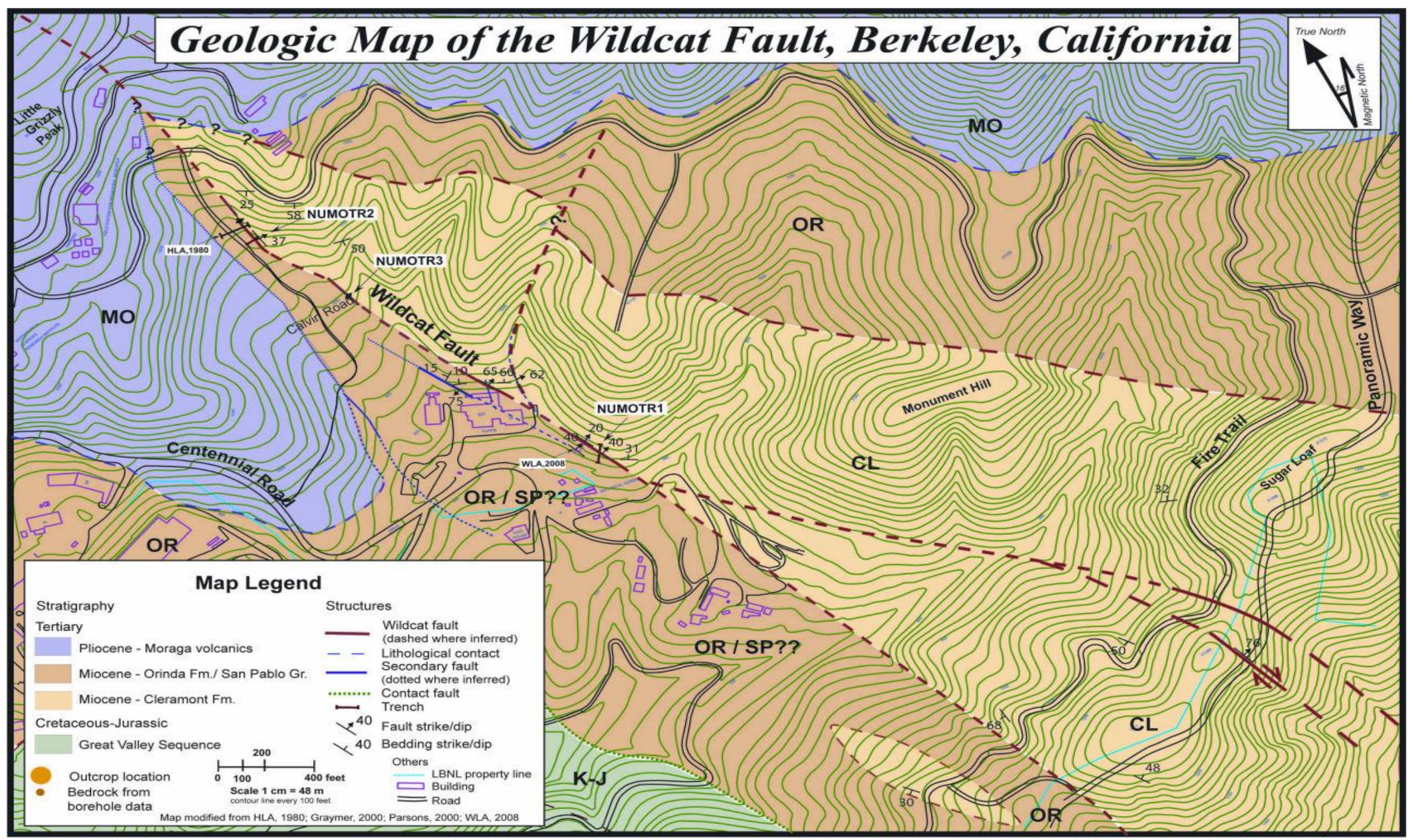

Figure 3-79. Geologic map of the Wildcat Fault, Berkeley California 


\subsubsection{D Model of the Site}

\subsubsection{Introduction}

Geological maps created by geologists are usually two dimensional in a plan view. This is particularly true when surface mapping and trenching are the only tools available for geologists to compile a geological map. Surface mapping and trenching only yield information regarding the surface geology. When information from boreholes is available, a cross sectional map or fence diagram are often drawn. However, geology is three dimensional. When faults rupture, they cut through depositional planes and displace them. It is very difficult to understand the relationship between geologic formations with only a two-dimensional map, in particular in the vertical dimension. A digital three dimensional geologic model would be very useful to visualize geologic sequences offset by faulting. When the hydrologic properties of geologic formations become available, a 3D geologic model can serve as the basis to construct a hydrogeologic model for groundwater flow and transport simulations.

\subsubsection{3D Model of LBNL Site}

Figure 3-80 shows the basic 3D GIS model, in which an aerial photo is draped over the $10 \mathrm{~m}$ grid DEM (digital elevation map) of the LBNL site and its vicinity. As can be guess from the figure, the terrain of the Berkeley Hills is very steep. The water table near the ground surface is strongly affected by the terrain as was discussed in Section 3.1.2.3.2. Based on the analysis of available geologic information discussed in Section 3.4.1, a crude three dimensional conceptual model of the site geologic structure has been created. Figure 3-81 shows the geologic structure of the model looking to the east cut by the Wildcat Fault. Figure 3-82 shows the cross-sectional view looking to the north of the model cut by a plane perpendicular to the Wildcat Fault. At this point, we have very little information at depth. The thickness of each formation is unknown. When information from planned boreholes becomes available, we will be able to verify/adjust the geologic structure of the model. 


\subsubsection{Future Plans}

We plan to incorporate additional pieces of information into the model as they become available and adjust the model accordingly. Expected additional data include those from planned trench studies on Panoramic Way and from the extension of the trench TR-2. Furthermore, we plan to drill multiple boreholes on both sides of the Wildcat Fault (see Section 3.5). Drill logs and core data should become available in the latter half of FY2009. The dip direction of the Wildcat Fault and its splays are still uncertain at depth. Abutting relationship of the geologic units on both sides of the fault at depth is unclear. We envisage using the 3D model to conduct 'what-if' scenarios to examine different hypotheses with regard to the fault movement and the resulting structure. Although we do not expect solve all the questions, we may be able to narrow the range of possible scenarios. 


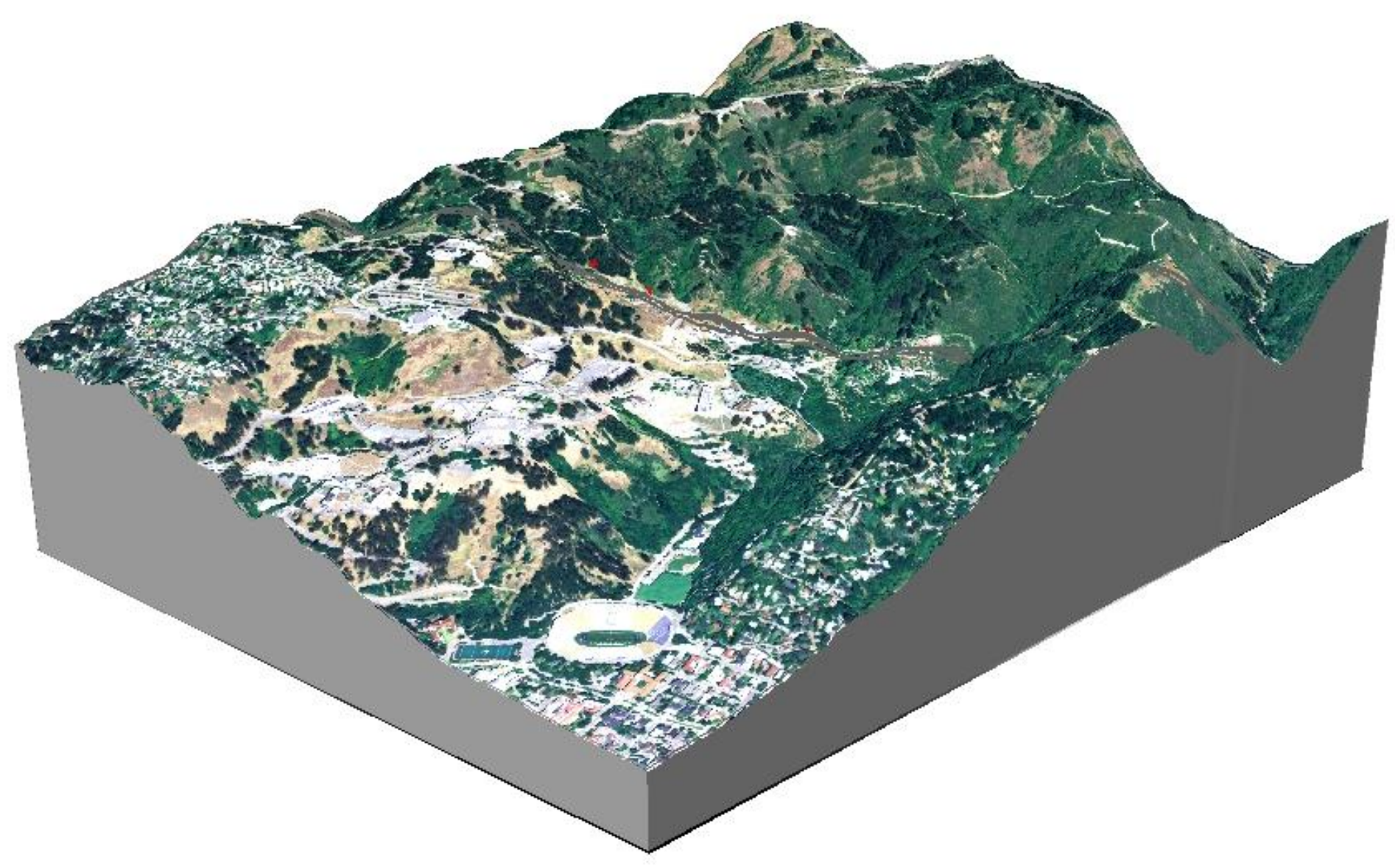

Figure 3-80. A 3D GIS model of the LBNL area with vertical exaggeration. 


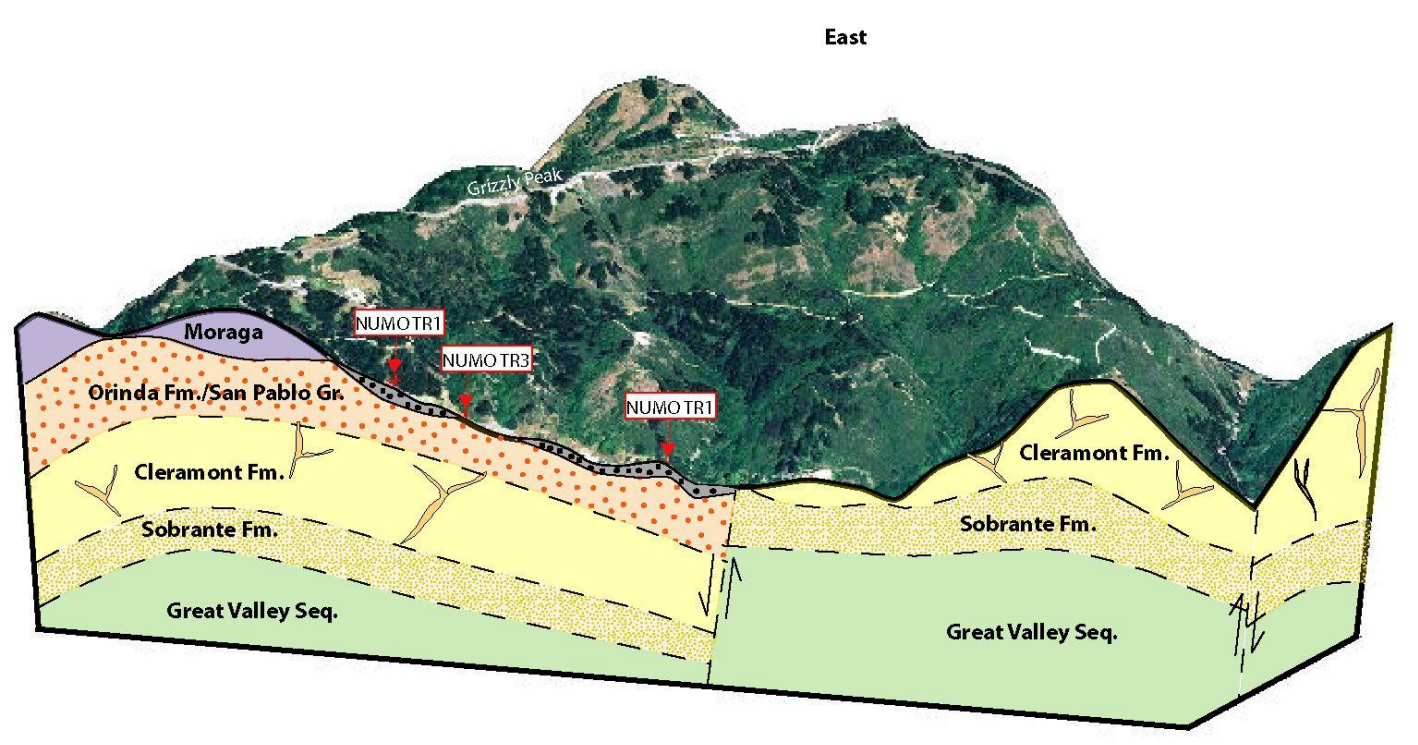

Figure 3-81. A view to the east of the Wildcat Fault plane.

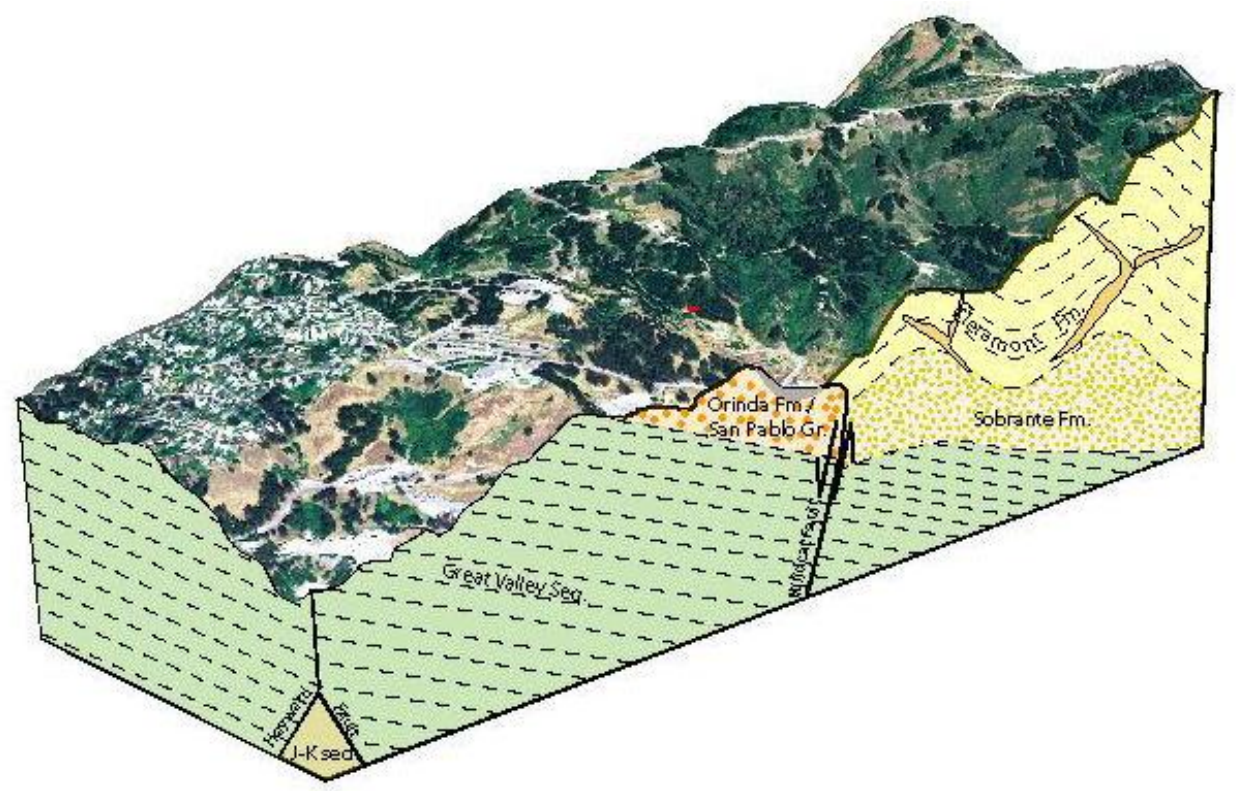

Figure 3-82 A view to the north of the cross-section perpendicular to the Wildcat Fault. 


\subsection{Planning of Borehole Investigations}

\subsubsection{Introduction}

LBNL サイトに於ける 3 箇所のトレンチ調査（第 3.3 .3 章参照）及び北側に隣接する FSBR と南側の Ridge Roadに於ける比抵抗電気探査並びに反射法地震波探査の結果(第3.3.1 章参照) を総合して照らし合わせると Wildcat 断層もしくはそれに関連した分岐断層が LBNL サイトの 東側部を南北に縦断していると断定できる。本章では、Wildcat 断層のボアホール調査の予備計 画について述べる。

ボアホール調査計画を策定するにあたり、様々な要素を考慮する必要がある。最優先すべき は水理試験を行ううえで最も有効で効率的な試験が可能なボアホール構成を創ることである。 しかしながら、実際に掘削をするには用地が必要であり、理想的な構成で掘削する事が困難な 場合が多い。また、ボアホールの掘削は地表調査段階で不明であったり不確実であったりした 断層構造についてその謎解きが出来る位置に掘削する事ができれば理想的である。

\subsubsection{Borehole Drilling Plan}

これまで述べた既存の情報、物理探査、地表調査、トレンチ調查、を総合してボアホールを 何処に掘削すれば最も効率的で効果的かの判断を行うのが理想的である。しかしながら、物理 探査やトレンチの箇所の選定でも直面した実際上の問題として、掘削リグを設置可能か否かが 大きなファクターとなる。高圧線、道路、建物、地形などの障害が大きなリミッティングファ クターである。これらの制約はわが国の候補地でも必ず問題となると予想される。

LBNL サイトに於けるボアホールの掘削の第一目的は Widcat 断層の水理性状の把握である。 無論、Wildcat 断層そのものの水理性状の絶対評価が第一目標ではなく、最終目標は断層の水理 性状の評価手法の高度化である。従って Wildcat 断層を対象としたボアホール掘削計画も Wildcat 断層の評価を正しく行いつつ、我が国でのアプリケーションを念頭に於いて計画する必 要がある。

\subsubsection{Borehole Depth and Numbers}

実際の概要調查では深さ $1000 \mathrm{~m}$ から $1500 \mathrm{~m}$ の深度のボアホールを数本掘削すると予想され るが、本プロジェクトでは $1000 \mathrm{~m}$ 級のボアホールを掘削するのは予算の制限からほぼ不可能で ある。従って、リグの大きさ、パッカーストリングの重さ等を考慮すると、深度 $100 \mathrm{~m}$ から最 
深でも $200 \mathrm{~m}$ 程度が最適であると考える。 ボアホールの掘削本数も予算、スケジュールに依 存するが、実際の概要調査と同程度と考えられる最低 3 本から 5 本のボアホールを掘削する予 定である。

予算、スケジュールを立てる都合上、何本のボアホールを掘るかを予め決めておく必要はあ るが、これらはあくまで予算作成の為と考え、結果的に何本掘るかは、各ボアホールを 1 本掘 る毎に検討評価し、調整すべきものである。これはボアホールの掘削位置や構成にも当てはま る。先に掘削したボアホールの解析速報を検討した後に次のボアホールに関する諸元を最終決 定するべきである。つまり、地質、水理的に無関係と言える程距離が離れていない限り同時に 複数のボアホールを掘削するのは極力避けなければならない。

\subsubsection{Borehole Locations}

概要調査では先ず文献調查等の既存データに基づき、一番重要かつ不確実要素を解明するべ くボアホールの位置を決定するが、それらの重要かつ不確実要素は断層に関連する場合が多い と予測される。本プロジェクトにおいては、これまでの調査から、Wildcat 断層の性状が LBNL の敷地内で未だに大きな不確実性を含んでいる。そこで次年度に掘削するボアホールの位置は 掘削リグのアクセスの可能性以外には以下の要素を考慮しながら決定する。

\subsubsection{Distance from Fault}

LBNL 敷地内の Wildcat 断層の東側は Claremont 層、西側は San Pablo 層又は Orinda 層、浅部 では Moraga 層の何れかである可能性が高い。第 3.3.1 章で述べた LBNL の北と南で行われた物 理探査の結果では、Wildcat 断層は西に $60^{\circ}$ 以上傾斜していると考えられる。従って、Wildcat

断層の西側の近傍で垂直に掘削すれば断層を貫通する可能性がある。しかしながら、最初のボ アホールで断層を貫通させるのが賢明かどうかは検討に值する。地質調査の観点からは、コア サンプルを採取する為にも断層を貫きたいところであるが、水理の面から考えると、両側の水 質と水位が異なっている場合、断層に孔を開ける事により水位の高い側から低い側へ地下水が 流れ（おそらく東側から西側へ）、水質が混ざる恐れがある。また開孔状態が続けば水頭も均 衡状態へと向かってしまう。

実際の候補地でも断層を貫くボアホールを掘削するのは深慮すべきである。しかしながら、 多くの場合、断層を貫かない限り、その性状を確実に把握するのは難しい。従って、本プロジ エクトでは当初、断層を貫かないようにボアホールを掘削、水理試験を行い、最後にコンファ 
メーションの目的で断層を貫くようにボアホールを掘削するのが賢明と考える。

\subsubsection{Water Levels}

ボアホールの位置を考える際、我が国における実際の概要調査ではボアホールの深度が深い 為恐らく問題とならないが、本プロジェクトに於いては予算の都合上、 $100 \mathrm{~m}$ 程度の深度のボア ホールを掘削予定の為、地下水位を考慮に入れなければならない。物理探査を行った FSBR や Ridge Rd.でボアホールを掘削するのは、リグのアクセスに関しては十分であり、物理探査の結 果とボアホール調査の結果が直接比較出来るという利点もある。しかしながら、FSBR も Ridge Rd. も両側に急傾斜している標高 $360 \mathrm{~m} 400 \mathrm{~m}$ の稜線沿いであり、地下水位がかなり低いと想定 される。Figure 3-83 に位置を示す SSL-1 の情報（Anderson, 2008）から推察すると地下水位は 地表から 80-90m 程度と推測され深度 $100 \mathrm{~m}$ のボアホールでは揚水試験などの水理試験が困難で ある恐れがある。一方、Figure 3-19 に示すように 74, 85 号棟付近の地下水位は地表から 10m 程度である。また、Kleinfelder (2001)によれば、貯水タンク用の道路を建設する際の調査ボー リングにおいて現在の NUMO-TR3 付近で深度 6 7m に地下水面を観測している。しかしな がらこの地下水面は宙水である可能性がある。実際、その他の深さ $10 \mathrm{~m}$ 程度の調査ボーリング では地下水面を観測していない。

\subsubsection{Candidate Drilling Locations}

断層からの距離、地下水位、アクセスの問題を総合的に考慮すると、第一候補として Figure 3-83 に黒塗りの数字で示す位置が最も適当であると考えられる。先ず、(1で示す断層の東側の 箇所に鉛直なボアホールを掘削する。Wildcat 断層が西に傾斜していれば断層を貫かないと予想 される。次に2の位置から鉛直方向に掘削する。Wildcat 断層から水平距離でおよそ70m 離れ

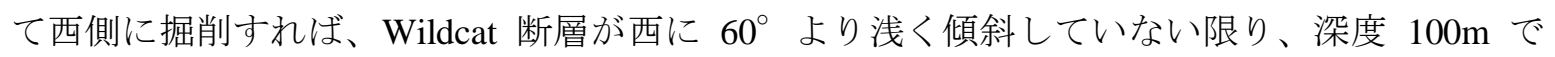
Wildcat 断層に当たることは無いと考えられる。最後にアの位置から傾斜掘りで Wildcat 断層を 貫くようにボアホールを掘削する計画である。また、Figure 3-83 の(1)、(2)、(3)の位置に掘削す る事も考慮する。

上記の(1のグループと(1)のグループの代替案として、Figure 3-84 に示すように LBNL の北 の Tilden Park Golf Course 内の緑の枠で囲った部分あるいは、LBNLの南に隣接する Botanical Garden でボアホールグループを展開する事も考慮すべきであろう。後者は掘削リグのアクセス が多少困難な可能性がある。大きなスケールで見れば図に示すように Wildcat 断層は、断層が 
確認されている 6 箇所の地点をほぼ直線で結ぶ。図の北端の Lake Anza を通り南は Ridge Road で確認された San Pablo 層とClaremont 層の境界である。

\subsubsection{Borehole Drilling}

ボアホールを掘削する際、コアボーリングをするか否かは考え方の分かれるところである。 コアボーリングはノンコアの 1.5 倍から 2 倍のコストが掛かり、ノンコアで掘削すれば同じ掘 削コストでより多くのボーリング孔の掘削が可能になる。水理学の観点から言えばより多くの ボーリング孔が存在する方がより少ない本数のボーリング孔でコアデータを得るより不確実性 の低減に役立つ(Karasaki et al, 2008)。妥協案としては、部分コアリングをするか、あるいは、 コアボーリング孔とノンコア孔を半々にする事も考慮するべきである。ノンコアのボアホール 掘削中には地質の専門家が常駐し、カッティングのログと掘削ログを行う。

また、地質状況によって掘削に泥水を使うか、清水又は Air Drill が可能かの判断を事前にす る必要がある。ケーシングは基盤岩以浅までは設置し、それ以深は可能なら裸孔を保つ予定で ある。ボアホールの径は径が小さい程、掘削コストがかからない。最近の MEMS 等に基づいた センサーは大きな径のボアホールを必要としない為、4 インチ以下程度の小さい径のボーリン グ孔を掘削する事も考慮中である。

\subsubsection{Borehole Logging}

ボアホールロギングに関しては更なる検討の余地はあるものの、全孔でコアボーリングを行 った孔に関してはスタンダードなロギングは特に行わない予定である。コアのないボーリング

孔ではカッティングログ等の掘削ログに加えてスタンダードなボアホールロギングを行う予定 である。温度検層は流入点や流動方向を推定する際に有効であるが、掘削の影響を大きく受け る為、掘削が終了し、ボアホールが安定した後に行うか、もしくは、連続的な温度分布が測定 可能な Fiber Optic Cable を利用したセンサーの埋め込みもオプションとする。

\subsection{Hydraulic Testing Plan}

水理テストは最終的なボアホール配置や、地層の透水係数にも依存するが、断層のコア、ダ メージゾーン、母岩のそれぞれの透水係数や広がりを推定する目的で行う。揚水試験が可能な ほど透水係数が高ければ揚水試験を行う。基盤岩の地表近傍は風化し透水係数が高いと予想さ れるので風化帯以深のボアホールのセクションで試験を行う。断層を貫くボアホール以外は全 
孔に渡って試験を行う。断層を貫くボアホールについては、コアデータもしくは掘削データに 基づいてパッカーで区間分けを行い、それぞれの区間について圧力試験を行う。透水係数が小 さすぎて揚水試験が困難な場合は圧入試権、もしくはスラグ試験を行う。

実際の概要調査のサイトでは断層を貫くようにボアホールを掘削するのは考慮の余地がある。 その理由は断層の遮水性を損なうおそれがあるからである。しかし、Wildcat 断層についてはた とえ損なっても被害が無いと考えられることから、最後に検証の目的で断層を貫くボアホール で試験を行うのが理想的であると考える。 


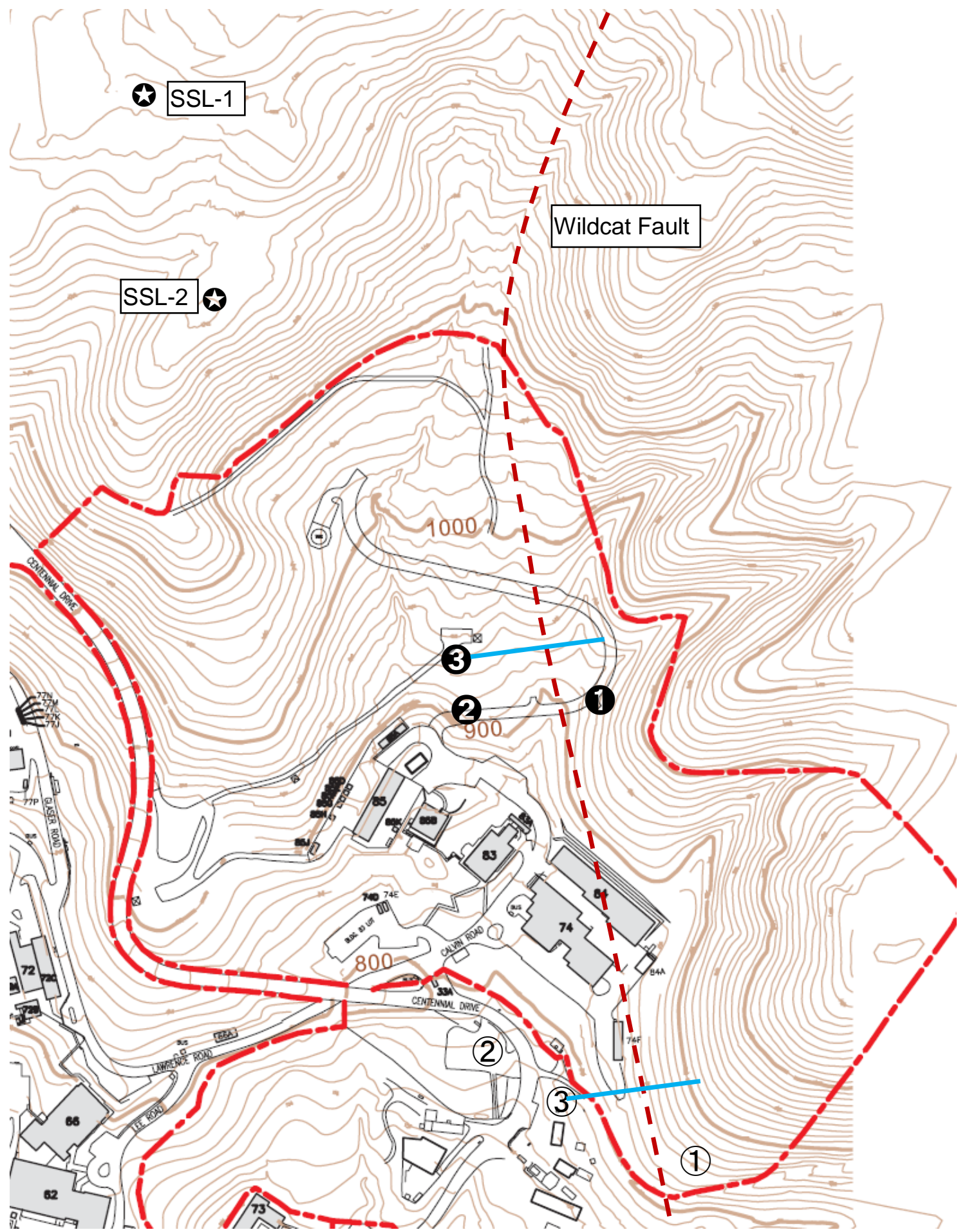

Figure 3-83. Potential borehole locations and existing deep boreholes SSL-1 and SSL-2 in relation to the Wildcat Fault. 


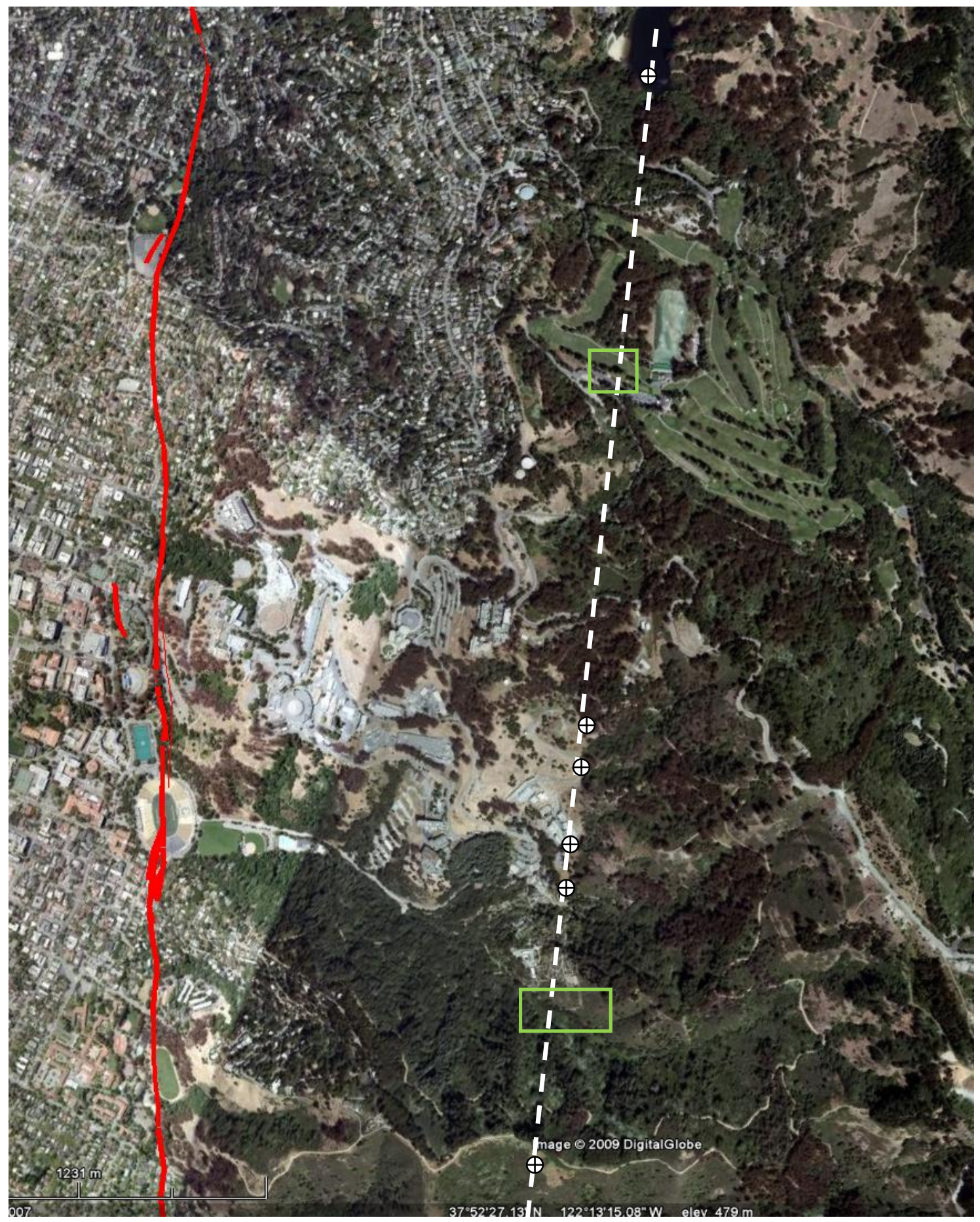

Figure 3-84. Hayward Fault (red) and Wildcat Fault (white). Symbols show where a fault is encountered along the Wildcat Fault Green squares show potential drilling locations outside LBNL property. 


\subsection{References}

Anderson, R., verbal communication, 2008.

Aydin, A., 1982, The East Bay hills, a compressional domain resulting from interaction between the Calaveras and Hayward-Rodgers Creek fault, in Hart, E.W. Hirschfeld, S.E., and Schulz, S.S., eds., Proceedings conference on earthquake hazards in the easternn San Francisco Bay Area: California Division of Mines and Geology Special Publication 62, p.11-22.

Atwater, T., 1998, An Animated Tectonic History of Western North America - a series of short computer animations, offered with narrative text via a web page

Bishop , C.C., Knox R.D., chapman R.H. Rodgers D.A., and Chase G.B., 1973, Geological and Geophysical Investigations for TriCities Seismic Safety and Environmental Resources Study. California Division of Mines and Geology Preliminary

Black, W., Geophysical Investigation Wildcat Fault, Berkeley, California, Letter Report to the Regents of the University of California, Job No. 08-684.03, March 2009.

Kiho, K., K. Ueta, K. Miyakawa, T. Hasegawa, S. Tanaka, T. Sasaki, M. Hamada, H. Suenaga, S. Kanazawa: CRIEPI Technical Report for Development of investigation and characterization technology of fault zone hydrology, CRIEPI, 2009.

Curtis, G.H., 1989, Late Cenozoic volcanic rocks of the central Coast Range, in Wahrhaftig, C., and Sloan, D., Geology of San Francisco and vicinity, Field trip guidebook T 105: Washington, D.C., American Geophysical Union, p. 33-35.

Daley, T., E. Karageorgi, T. McEvilly, LBNL High Resolution Seismic Reflection Profiles Site Characterization Program Status Report - January 1996

Daley,, T., High Resolution VSP Surveys in Shallow Ground Water Monitoring Wells at Lawrence Berkeley Laboratory, LBNL, RCRA Facility Investigation Report, 2000.

Dames \& Moore, 1962, Soil Investigation, First increment, Proposed Animal Bioradiological Laboratory, Lawrence Berkeley Laboratory Berkeley, California. Report \# 236_00001

Geo/Resource Consultants, Inc., 1994, Geotechnical Investigation. Replacement Hazardous Waste Handling Facility. Lawrence-Berkeley Laboratory, Building 85, Berkeley, 
California. GRC job number 1393-000. Report \# 339_085. pp.133

GeoRecource Consultants, Fault Investigation Building 85 Hazardous Waste Handling Facility, Lawrence Berkeley Laboratory, Report 1746-003, 1994.

Gilpin, L., 1994, Geologic Evaluation, Wildcat Fault, Human Genome Laboratory, Laboratory, Lawrence Berkeley Laboratory Berkeley, California. Report \# 396_00001

Graymer, R.W., 2000, Geologic map and map database of the Oakland metropolitan area, Alameda, Contra Costa and San Francisco Counties, California. USGS Miscellaneous Field Studies MF3242g. Version 1.0

Graymer, R.W., Sarna-Wojcicki, A.M., Walker, J.P, McLaughlin, R.J., and Fleck, R.J., 2002, Controls on timing and amount of right-lateral offset on the East Bay fault system, San Francisco Bay region, California. GSA Bulletin; December 2002; v. 114; no. 12; p. 1471-1479

Graham, S. A., McCloy, C., Hitzman, M.,Ward, R., and Turner, R., 1984, Basin evolution during change from convergent to transform continental margin in central California: American Association of Petroleum Geologists Bulletin, v. 68, p. 233-249.

Harding Lawson Associates (HLA), 1974, Geologic investigation - Building 74 addition, Lawrence Berkeley Laboratory Berkeley, California. Report \# 238_00001

Harding and Lawson Associates, Preliminary Geologic Investigation East Canyon Area, Lawrence Berkeley Laboratory, 1976.

Harding Lawson Associates (HLA), 1977, Foundation investigation - Cell Culture Facility, Lawrence Berkeley Laboratory Berkeley, California. Report \# 183_00063

Harding Lawson Associates (HLA), 1980, Wildcat Fault Study Bio Medical Laboratory II Project Lawrence Berkeley Laboratory Berkeley, California. Report \# 041-0020

Harding Lawson Associates (HLA), 1982, Geology of Lawrence Berkeley Laboratory. HLA Job no. 2000,135.01. Report \# 042_00

Harding Lawson Associates (HLA), 1985, letter provides our evaluation of the proposed library site located along the southwest edge of the existing paved parking lot west of Building 74. Report \# 164-0001

Jones, D.L. and Curtis, G., 1991, Guide to the geology of the Berkeley Hills, Central Coast 
Ranges, California in Geologic Excursions in Northern California: San Francisco to the Sierra Nevada, California Departmanent of Conservation, Division of Mines and Geology. Special Publication 109, pp 63-73

Jordan, P., Wildcat Fault Observations at the Building 84 excavation, Internal Report, LBNL, \#359-084, July 1997.

Jordan, P., Personal Communication, 2008.

Karasaki, K., Tiemi Onishi, and Yu-Shu Wu, Development of Hydrologic Characterization Technology of Fault Zones, LBNL-1635E, 2008.

Kleinfelder, Geothechnical Investigation - Proposed road and water tank Lawerence-Berkeley National Laboratory, Berkeley California. Report \#384_00002, 2001.

Lawson, A.C. and Palache, L., 1900, Geological Map of Portion of the Berkeley Hills

LBNL, RCRA Facility Investigation (RFI) Report, September 2000, . http://www.lbl.gov/ehs/erp/html/documents-rfi-2000.shtml

LBNL, Environmental Restoration Program Quarterly Progress Report and Annual Status Summary, 4th Quarter, July-September, 2004.

LBNL, Environmental Restoration Program Quarterly Progress Report, Fourth Quarter and Annual Status Summary Fiscal Year 2006, July to September, 2006.

LBNL, Environmental Restoration Program Quarterly Progress Report and Annual Status Summary, Fiscal Year 2008, 3rd Quarter, April-June, November 2008.

LBNL and Parsons, 2000, RCRA Facility Investigation Report for the Lawrence Berkeley National Laboratory ENVIRONMENTAL RESTORATION PROGRAM. A Joint Effort of Environment, Health and Safety Division and Earth Sciences Division Lawrence Berkeley National Laboratory University of California Berkeley and Parsons Engineering Science, Inc.

McClay, K. and Bonora, M., 2001, Analog models of restraining stepovers in strike-slip fault systems, AAPG Bulletin, v.85, n.2, pp. 233-260.

Maliave, B., 1965, Geologic Map, Lawrence Radiation Laboratory, Omnitron Site Study. Dec.26 1965. 
Simpson, R.W., 2000, Watching the Hayward Fault, Science, 18 August 2000. pp. 1147-1148. http://www.sciencemag.org/cgi/content/full/289/5482/1147

Page, B.M., 1950, Geology of the Broadway Tunnel, Berkeley Hills, California. Economic Geology, v.45, pp.142-166.

Sloan, D., Karachewski, J., 2006, Geology of the San Francisco Bay Region (California Natural History Guides) no. 79. 337p.

Subsurface Consultants, Geologic Evaluation Wildcat Fault, Human Genome Laboratory Lawrence Berkeley Laboratory, Berkeley California, 1994.

Untermann, B. R., 1935, A study of the Wildcat fault in the Berkeley Hills. MS Thesis, University of California Berkeley

US Geological Survey, 2008, Understanding Earthquake Hazards in the San Francisco Bay Region. The Hayward Fault - Is it due for a repeat of the powerful 1868 Earthquake? USGS Fact Sheet 2008-3019.http://pubs.usgs.gov/fs/2008/3019/fs2008-3019.pdf

William Lettis and Associates, Surface-fault Rupture Hazard Investigation of the Wildcat Fault Proposed General Purpose Lab, Lawrence Berkeley National Laboratory, Berkeley, California, November, 57p, 2008. 


\section{Summary and Conclusions, Lessons Learned}

\subsection{Summary and Conclusions}

Here we briefly summarize the findings and conclusions from the studies conducted in FY2008. These studies include: literature survey on fault zone hydrology, analysis and compilation of existing information of the Wildcat Fault, aerial photo analysis, geophysical, surface geologic and trench investigations of the Wildcat Fault and the surrounding geology.

- Based on a comprehensive literature survey on the relationship between hydrologic and geologic properties of faults, it was concluded that faults can be classified into eight different types based on various geometric and geological attributes. These types may be used to indirectly infer the hydrologic properties of faults.

- An investigation flow diagram specifically designed for fault zone characterization was developed.

- Based on the analysis of aerial photographs of the Wildcat Fault it is postulated that the fault may have different properties in the north and in the south of LBNL.

- Combined analysis of electrical resistivity surveys and seismic reflection surveys conducted on the Panoramic Way on the south and at Field Station for Behavioral Research on the north yielded the images of the Wildcat Fault: one steeply dipping to the west and another shallowly dipping to the west. However, multiple interpretations are possible.

- Three trenches were excavated, in all of which at least one fault was encountered. Detailed mapping and structural analysis were conducted in these trenches.

- Based on a structural analysis of the faults observed in the trenches, it is suggested that the low angle faults may be low permeability and the high angle fault may exhibit relatively high permeability.

- A geologic map was compiled based on previous work from geotechnical and geological data, field observations, and trenching. Although the Wildcat Fault is shown as a singular trace in the LNBL property. The fault may splay in several branches.

- A conceptual model of the Wildcat Fault have been developed, which assumes that 
some faults may be a part of the flower structure or splays of the Wildcat Fault.

- The question of whether the portion of the Wildcat Fault in LBNL property is part of an extensional jog structure or transpressinal structure is unanswered. Further analysis in the coming years should shed more light on the question.

- Borehole drilling plan and hydrologic testing strategy were developed. Hydrologic properties of the Wildcat Fault will be investigated through borehole drillings in the coming years.

\subsection{Lessons Learned}

本節では主として 2008 年にLBNL で行われた現地調査における Lessons Learned を列挙する。 本プロジェクトと実際の処分場候補地での概要調査の為の現地調査を比較すると本プロジェク トの規模は格段に小さいが、ほぼ同様な手順や手法が用いられていることから、今回の研究で 得られた経験は実段階でも通用すると考えられる。

\section{Heterogeneity near Ground Surface}

20m 離れただけでも地層が全くと言って良いほど変わっている場合がある。NUMO-TR1 の掘 削に関しては実際その通りであった。William Lettis Associates (WLA)のトレンチT-2 で確認され た断層は初代 NUMO-TR1（以後 TR-0 と呼ぶ）ではそれらしき断層が予想される位置より数m 東側で確認され、さらに 20m 離れた NUMO-TR1 では断層が確認できなかった。従って、近傍 と言えど地質データを外挿する場合は細心の注意が必要である。

\section{Effects of Landslides}

急峻な斜面を有した土地では、地層や断層の走行や傾斜が地表近くでは地すべりによって移 動している可能性を考慮しなければならない。WLA のトレンチで確認された断層は東に傾斜し ていたが、初代 NUMO-TR0 ではほぼ垂直であった。また、NUMO-TR 3 で確認された断層もほ ぼ垂直の傾斜であった。この事から、WLAの断層は地滑りに影響された傾斜を示している可能 性がある。

\section{Trench Excavation}

トレンチ掘削の際は、必ず地質学の専門家が立ち会うべきである。安全確保した上で、ショ ベルカーのショベルから搬出される土砂の中身を随時観察するのが望ましい。必要ならトレン チの箇所、方向、深度をその場で変更できるフレキシビリティが望まれる。 


\section{Irretrievable Data}

特性評価に関連するデータを取得するチャンスがあれば、必ず記録しておく。暫定的なデー タであれば特記事項として注釈し記録する。すべてのデータを再取得できないデータ (irretrievable data) として扱うべきである。その理由は何らかの原因で再び同じ条件で調査が 出来ない可能性があるからである。実際、NUMO-TR0 ではトレンチ掘削途中に Tcc と Tsp のコ ンタクトが目視されたが、完成後に詳しいデータが取得可能であると考え、写真撮影、測量等 のデータ取得を一切行わなかった。しかし、安全管理上の理由で結局 TR0 は埋め戻しとなり、 断層のデータを取得することが不可能となった。

\section{Weather}

現地調査のデータの品質や調査の安全性は天候に大きく左右されるので十分余裕のあるスケ ジュールを組む必要がある。地震探査に於いては Geophone が雨の振動を拾ったり、急坂地で は大きな震源の移動に危険さえ伴う。また、電気探査も雨に左右されることから注意が望まし い。反対に、雨季の前後に測定を行い、比抵抗の時間変化（time lapse）に関して解析を行うと 断層検知の解像度が上がる可能性がある。

\section{Existing Information}

既存の地質図やその他のデータは新たな現地調査で同じデータを取得する重複を避けられ、 時間や予算の節約につながるが、その扱いに十分注意をする必要がある。多くの場合、データ が取得された状況や手法、あるいは地質図上の地質境界線や断層を表す曲線に対する根拠が不 明であり、品質が保障されなかったり、現在進行形で取得されるデータと比較して品質に関し て不均等である事が多い。従って、既存データに誤りがある可能性を常に考慮しておく必要が ある。第 2 およびセクション3.1.2.1 でも述べたが、既存の地質図を鵜吞みにする事は極力避け るべきである。

\section{Practical Constraints}

トレンチ掘削箇所や物理探査の測線を取る場所はプラクティカルな状況や制約に大きく左右 される事を覚悟しておくべきである。多くの場合、最も理想的な箇所に於いてトレンチを掘削 したり、物理探査を行えない場合が多い。例えば、空中写真のリニアメントから測線を決定し ても実際現地に赴くと急坂地であったり、塀、高圧線、その他の人工の障害物がある場合があ る。数々制約の中でベストオプションを選ぶ事が肝要である。 


\section{Alternative Plans}

複雑で予測の難しい地下の特性調査は当初の計画や予定通りに行かない事が多々ある。従つ て、概要調査の実施にはフレキシビリティが必要であり、常に代替プランを用意しておくべき である。本プロジェクトにおいてもなんらかの理由で Wildcat 断層以外の断層を調査する必要 が生じる可能性がある。Appendix 3 に代替もしくは追加のサイトとなりうる MissionFault の概 要を添付する。

\section{Time Lapse Geophysical Survey}

一般に物理探查で物性の絶対值の対比による細かい構造を検知するのは困難であるが、タイ ムラプス、つまり経時変化を捉えることによって構造が明らかになる場合がある。例えば比抵 抗電気探査の場合、乾季と雨季に 2 度調查をし、比抵抗の変化をインバージョンすると雨水が 浸透しやすい断層や亀裂がイメージできる可能性がある。今回の調査でも時間と予算に余裕が あればタイムラプス調査をすることにより断層の性状の不確実性が低減できた可能性がある。

\section{Safety Issues}

現地調査中の安全管理は最重要視されなければならない。今回の現地調査中に偶然に LBNL の安全管理体制が大幅に強化され、様々な予定変更を余儀なくされた。しかし、実際に安全管 理は現地調査の重要な柱と考え、遅延や予算の増大を避ける為にも、当初から安全管理を一体 にした調査計画を立てる必要がある。 
Acknowledgements

This work was performed under the U.S. DOE Contract No. DE-AC02-05CH11231. 


\section{Appendix 1}

Wildcat 断層における物理探査とトレンチ調査プログラム(案)

October 16, 2008 


\section{Wildcat 断層こお計る物理罙査とトレンチ調查プログラム (案)}

1. 背景

Wildcat 断層は LBNL の南北では航空写真によるリニアメントの判読や文献等からそのトレ ースが確定しているが、敷地内においては沖積層、地すべり、道路や研究棟建設等の土木工事 の影響で地表でのトレースがはっきりと確定していない部分がある。しかし、図 1 に示すよう に、4 箇所のトレンチおよび土木工事時の掘削において断層の存在が確認されており、これら はほぼ一直線上に並ぶ。また、測定された走行もほぼ一致する。これらの 4 点を直線で結べば、 ほぼ Wildcat 断層の LBNL 敷地内のトレースは確定するが、一説によれば、地表付近では Wildcat 断層はフラワー構造やステップ構造になっており、複数のトレースが存在する可能性もある。 しかし、この考え方は 84 号棟を建設中に確認された断層においてシュードタキライトが確認さ れた事実とは矛盾する。

Wildcat 断層を横切った側線において物理探査の調査、及びトレンチ掘削を行う際に、種々の 手法の物理探査やトレンチ掘削を同一箇所で実施するのが望ましい。その理由は同じ断層でも 場所によって構造および性状が異なっていたり、被りや人工物等のノイズの状況も違っており、 それぞれの手法の結果の比較が困難であるからである。しかし、全てを同一箇所で実施するに は以下の物理的制約や困難を伴う。
A）電気探査においてはガードレールや金属製の塀やケーブル等の埋設物が大きなノイズと なるので、出来る限り避ける必要がある。
B）地震探査では、起伏の激しい場所では震源を積んだトラックを乗り入る事が不可能であ る。
C）地表堆積物の被りの厚い箇所では何れの物理探査手法も鮮明さを欠き、トレンチも基盤 岩に達するまで深く掘り下げるとコストや安全面で問題がある。
D）物理探査では精度と深度(スケール)は負の相関性がある。

従って、予算・時間・立地条件等の制約の範囲内で、技術的に最適な物理探査とトレンチ調 査のプログラムを組むことが求められる。LBNL の物理探査の専門家と民間の物理探査調査会 社と検討を重ねた結果、以下に 2008 年度に Wildcat 断層で行う予定の物理探査手法を挙げる。

\section{2. 物姃罙査手法}

\subsection{Seismic Refraction Method}


屈折法と呼ばれるこの方法は側線上に並べられた受振器において側線上の異なった位置の震 源から発せられた $\mathrm{P}$ 波の到達時間を元に $\mathrm{P}$ 波速度の分布を 2 次元断面的に求め、 $\mathrm{P}$ 波と相関性 の強い岩石の剛性分布の違いから地下の構造を類推する。

\subsection{MASW (Multi-channel Analysis of Surface Wave)}

この手法は表面波（Surface Wave）の到達深度と速度は波長の関数であること、表面波と S 波の理論的相関性と $\mathrm{S}$ 波が断層や亀裂などの不連続面において著しく減衰する事を利用して地 下の $\mathrm{S}$ 波速度の分布から断層や岩層のコントラストをイメージする手法である。

\subsection{Resistivity Profiling}

地表面から地下に直流電流を流し、2 点間の電位差を測って地下の比抵抗分布を 2 次元的に 求める手法である。岩種によって電気抵抗が異なる事を利用して地下の地質構造を類推する。 地下水の TDS が多く比抵抗が小さく地層とのコントラストがあれば、地下水面がイメージでき る場合もある。

\section{3. 㸮理染查䒠施暢所}

図 1 において、（A）で示される Animal Behavior Research Center の敷地内で、上記 3 つの手 法を同一側線上で寒施する。加えて、(B)および、(C) (D) の両方もしくはどちらかで電気抵抗 探査をおこなう。従って、電気抵抗探査は合計 3 側線もしくは 4 側線、地震波探査は屈折法と MASW 法を（A）の 1 側線で行う予定である。

4. トレンチ掘尚临所

トレンチの掘削は側線（B）の近傍で行う予定である。此処では道路の建設時に LBNL の Preston Jordan によって断層の存在が確認されており、被りも比較的薄いと考えられる。

5. スケジュール

全当事者の合意が得られた後、外注の諸手続きに 2,3 週間要するので早くても物理探查測定 の実施は 11 月の初旬となる公算が強い。可能ならその直後にトレンチ掘削を行う。 


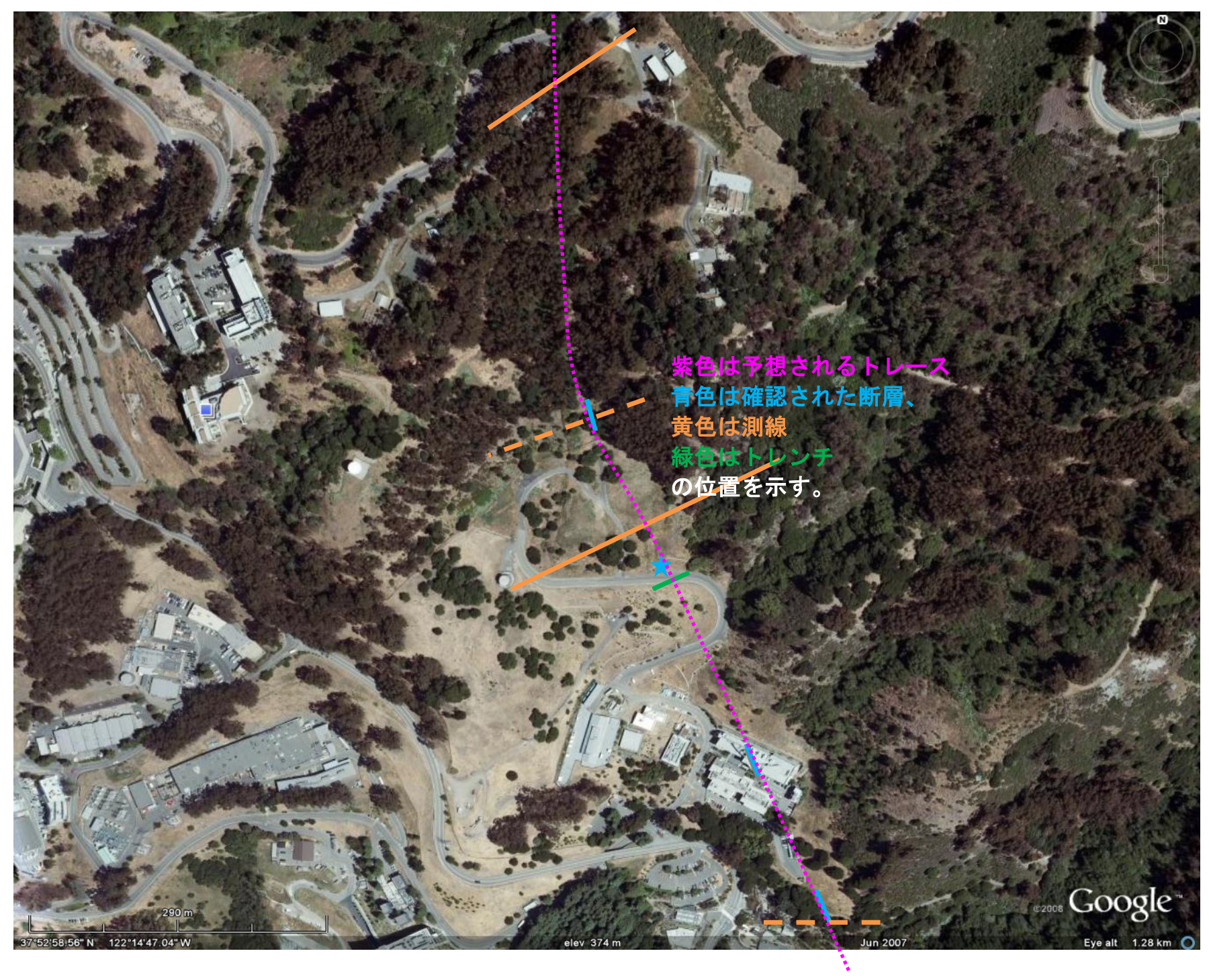

Figure A-1. Initial planned locations of geophysical survey lines and a trench. 
Appendix 2

\section{NUMO LBNL Collaborative Project Kick-off meeting agenda}

September 12, 2008 


\section{Development of Hydrologic Characterization Technology of Fault Zones}

-Kickoff Meeting and Site Tour-

A NUMO-LBNL Collaborative Project

September 12, 2008

\begin{tabular}{|r|l|}
\hline $\begin{array}{r}\text { Friday, September 12, } \\
20 \\
\text { 9AM-2:00PM } \\
\text { Rm-1099, LBNL }\end{array}$ & \\
\hline $9: 00$ am: & $\begin{array}{l}\text { Welcome and the status of Yucca Mountain Project } \\
\text { Jens Birkholzer, Head, Nuclear Waste Dept., LBNL }\end{array}$ \\
\hline $9: 15$ am: & $\begin{array}{l}\text { Status of NUMO activities and perspective of the } \\
\text { Project Junichi Goto, Science and Technology Dept., NUMO }\end{array}$ \\
\hline $9: 30$ am: & $\begin{array}{l}\text { Project Overview } \\
\text { Kenzi Karasaki, LBNL }\end{array}$ \\
\hline $9: 45$ am: & $\begin{array}{l}\text { LBNL Workplan } \\
\text { Kenzi Karasaki }\end{array}$ \\
\hline $10: 00 \mathrm{am}$ & $\begin{array}{l}\text { LBNL site geology overview } \\
\text { Preston Jordan }\end{array}$ \\
\hline $10: 25 \mathrm{am}$ & $\begin{array}{l}\text { EM and Resistivity survey } \\
\text { Erika Gasperikova, }\end{array}$ \\
\hline $10: 50 \mathrm{am}$ & $\begin{array}{l}\text { Geological survey and Trenching } \\
\text { Tiemi Onishi }\end{array}$ \\
\hline $11: 30 \mathrm{am}$ & $\begin{array}{l}\text { CRIEPI Workplan } \\
\text { Kenzo Kiho and others, CRIEPI }\end{array}$ \\
\hline $1: 00 \mathrm{pm}:$ & $\begin{array}{l}\text { Open Discussion } \\
\text { All }\end{array}$ \\
\hline $1: 30 \mathrm{pm}:$ & $\begin{array}{l}\text { Wrap up and plan for next meeting } \\
\text { Kenzi Karasaki }\end{array}$ \\
\hline $2: 00 \mathrm{pm}:$ & $\begin{array}{l}\text { Site tour } \\
\text { Wild Cat Fault, Hayward Fault }\end{array}$ \\
\hline $6: 00 \mathrm{pm}:$ & Dinner at TBD location \\
\hline &
\end{tabular}

Attendees:

\begin{tabular}{|r|l|}
\hline NUMO: & Hiroyuki Tsuchi, Junichi Goto, Satoru Suzuki \\
\hline CRIEPI & $\begin{array}{l}\text { Kenzo Kiho, Kimio Miyakawa, Keiichi Ueta, Takuma } \\
\text { Hasegawa }\end{array}$ \\
\hline LBNL: & $\begin{array}{l}\text { Jens Birkholtzer, Mark Conrad, Erika Gasperikova. Ramsey } \\
\text { Haught, Preston Jordan, Kenzi Karasaki, Tiemi Onishi, Rohit } \\
\text { Salve. }\end{array}$ \\
\hline
\end{tabular}


Appendix 3

Mission Fault at Ohlone College

-A Potential Alternative/Additional Site- 


\section{Introduction}

The Mission Fault is located between Hayward and Calaveras Fault. It is part of a contractional stepover between these two faults. The Hayward and Calaveras faults are the major component of the San Andreas Fault system in the San Francisco bay area (Fig. A3-1). The Mission Hills are the result of this contractional stepover which is accommodated by folding and reverse faulting (Jones et al., 1994; Graymer et al, 1994). Uplift of the Mission Hills was coeval with the regional uplift of the California Coast Ranges and is estimated to have commenced 3.5 Ma (Harbert and Cox, 1989 in Manaker, et al, 2005). The minimum vertical displacement on the Mission Fault is $520 \mathrm{~m}$ based on late Miocene to early Pliocene rocks. This uplift has been linked to several landslides that have occurred in the area. The trace of the Mission Fault was inferred by Hall (1958) as parallel to a fault line scarp at the base of the west side of the Mission Peak. Two concealed branches of the Mission Fault were recognized in the vicinity of the present Ohlone College campus property. According to Manaker et al, 2005, geological and seismological evidences suggested that the Mission Fault may not be the source of seismicity in the region and it's not playing a major role in slip transfer between the Calaveras and Hayward faults. 


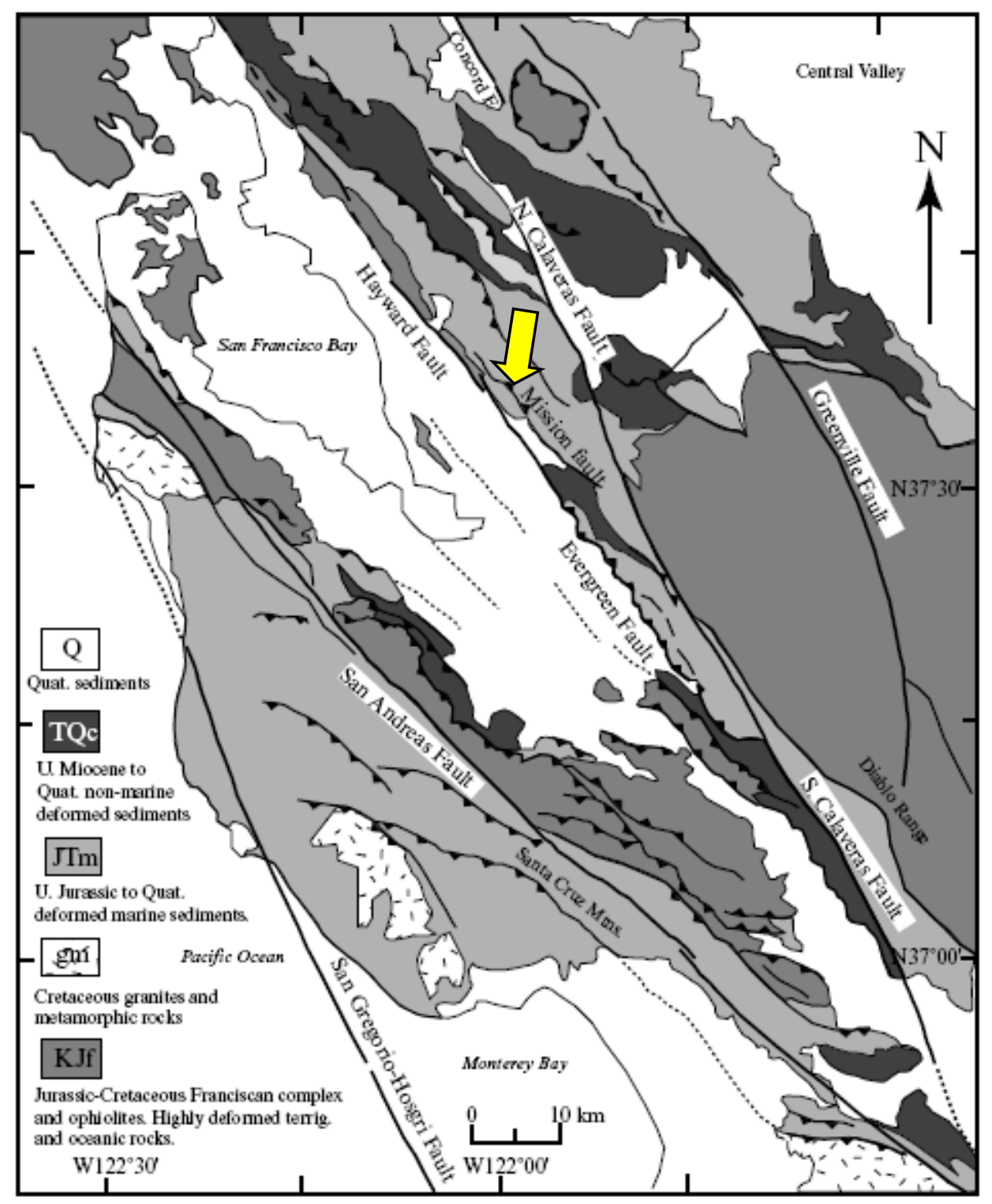

Figure A3-1- Schematic geology of the San Francisco Bay Region, California (after Manaker et al, 2005)

\section{Oholone College}

Oholone College is a community college located in Fremont, CA. It is situated approximately 64 kilometers from Lawrence-Berkeley National Laboratory (Fig. 2). 


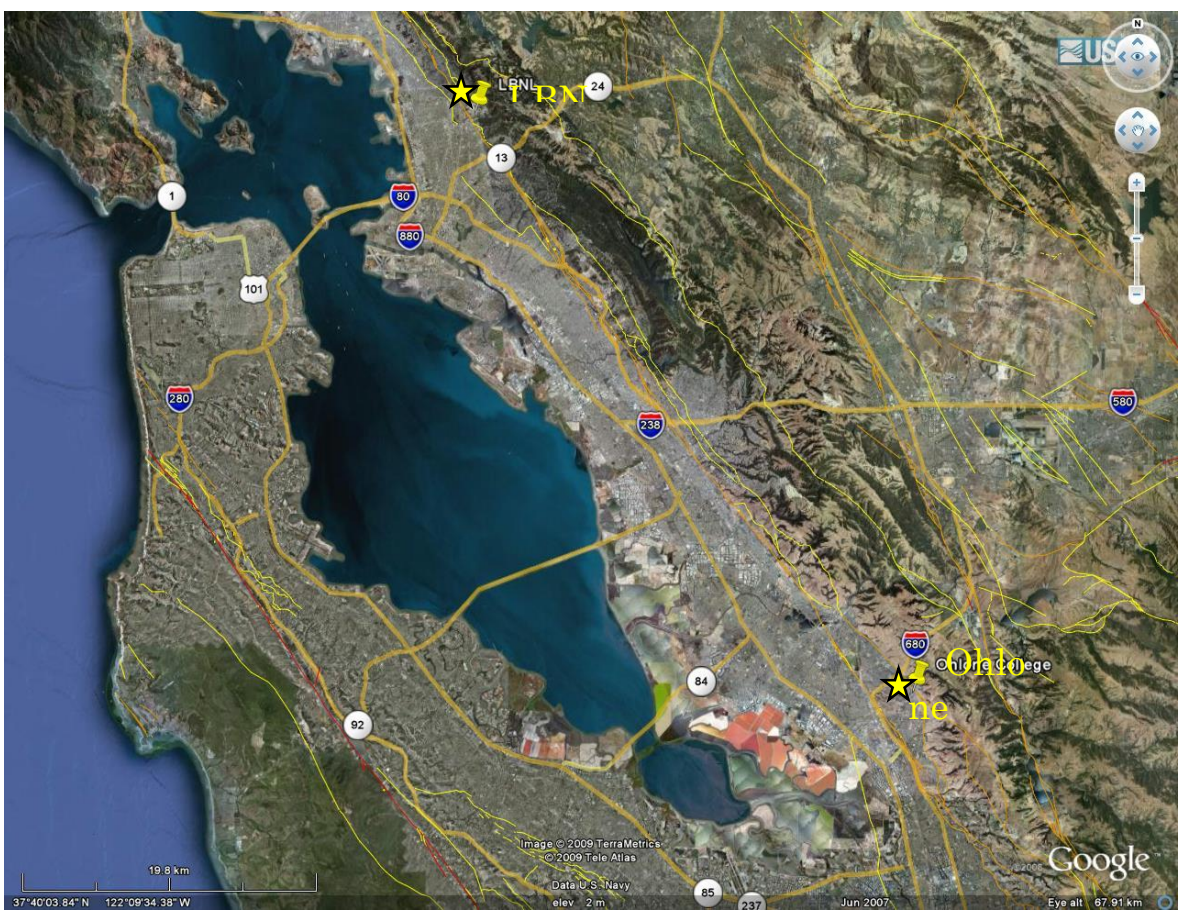

Figure A3-2 - Map showing the location of the Ohlone College relative to LBNL

The Mission Fault cuts the college property in northwest-southeast direction. The college had issues with water infiltration in the campus buildings. To solve this problem, Weiss Associates was engaged in developing a solution for groundwater intrusion at Ohlone College Campus (Fig. A3-3). Their investigation consisted of (a) establishing monitoring wells to determine the current ground water levels; (b) seismic surveys to determine the underlying geological structure and to tie it to the hydrology; (c) gathering data from borehole geophysical logs on underlying geological structure; and (d) examining core samples to provide visual samples of the hydrogeological features. This information was used to formulate a concept of the hydrogeological features of the campus. 


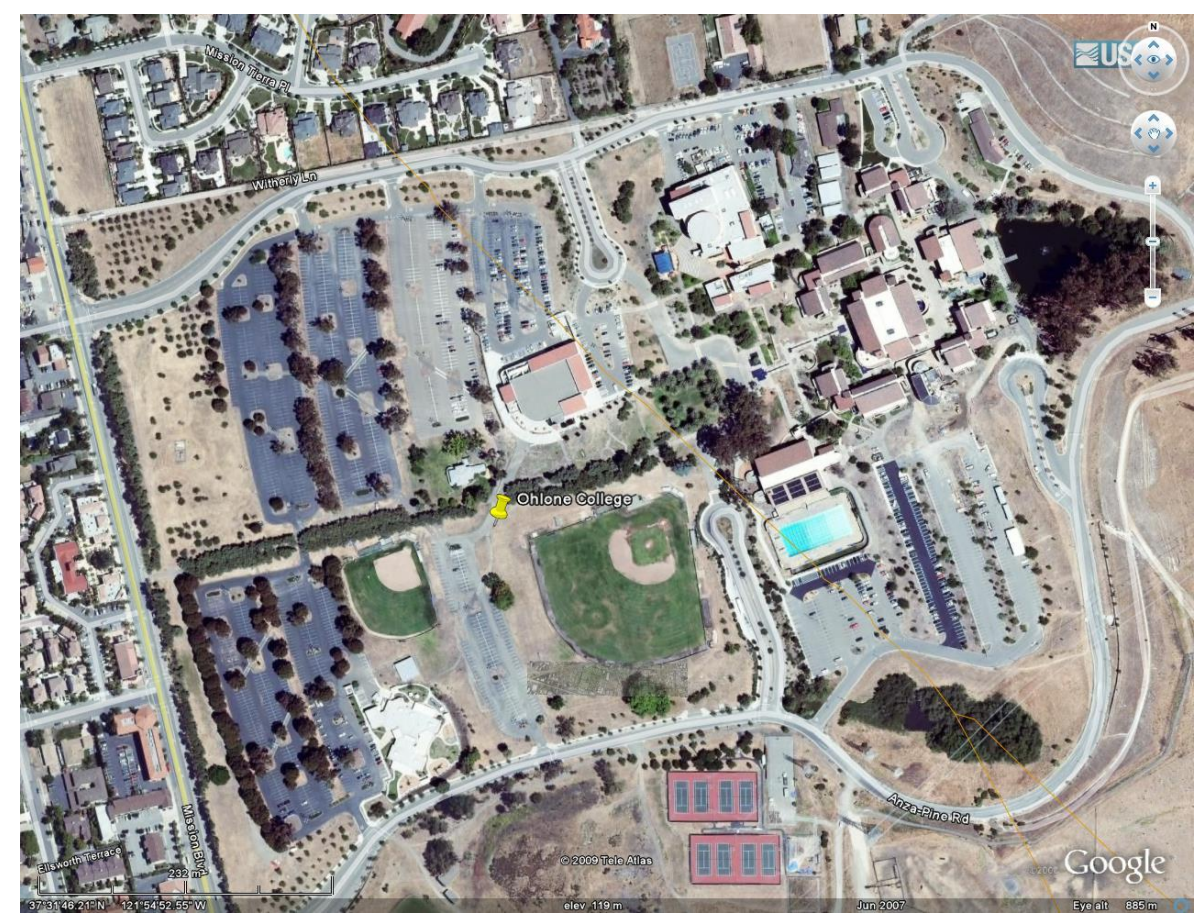

Figure A3-3 - Google map image of the Oholone College campus in Fremont, CA

\section{Geology}

The Ohlone College campus is located near to a coalescing landslide complex. The campus is underlain by channel fill and alluvial soils. The bedrock comprises the Tertiary San Pablo Group (Fig. A3-4) (Weiss Associates, 2009). The main lithologies are:

\section{Briones Formation (Tbr)}

The Briones formation is the lower part of the San Pablo Group. It consists of a massive fine to medium grained yellow to brown sandstone. The sandstone mapped as composing the hillslope immediately east of the Ohlone College campus and beneath the western campus. Briones sandstone are extensively fractured due faulting.

Neroy Formation and/or Cierbo sandstones (Tn)

The Cierbo Sandstone (Tc) is a sandstone and interbedded siltstone containing some pebbles or large cobbles (Hall, 1958), which ranges from gray or gray-brown finer-grained 
beds to blue or blue-mottled coarser-grained beds. The overlying Neroly sandstone is primarily a friable gray to bluish-purple coarse-grained sandstone (Hall, 1958). Although these bedrock units have not been mapped in surface exposures in the Ohlone College campus area, they are stratigraphically above the Briones Formation and below the Orinda Formation in nearby areas (Hall, 1958; Graymer et al., 1996, Plate 4; and Rogers and Drumm)

\section{Orinda Formation (To)}

The Orinda formation is composed by sediments deposited in fresh water such as conglomerate, sandstone, claystone, limestone, tuff and shale (Hall, 1958). This unit was mapped as overlain the Briones formation southeast of the Ohlone College campus.

\section{Irvington Gravels (QTi)}

The Irvington gravels corresponds a Pleistocene deposit and the uppermost lithofacies of the Santa Clara Formation. It is composed by poorly consolidated to semi-consolidated cross-bedded massive sandstone interbedded with some clay and large quantity of gravels. It can exceed $500 \mathrm{ft}$ in thickness.

\section{Quaternary deposits (Qu)}

Thin layers of alluvium occur in the vicinity of the Ohlone College campus. Fill material are observed throughout the campus. 


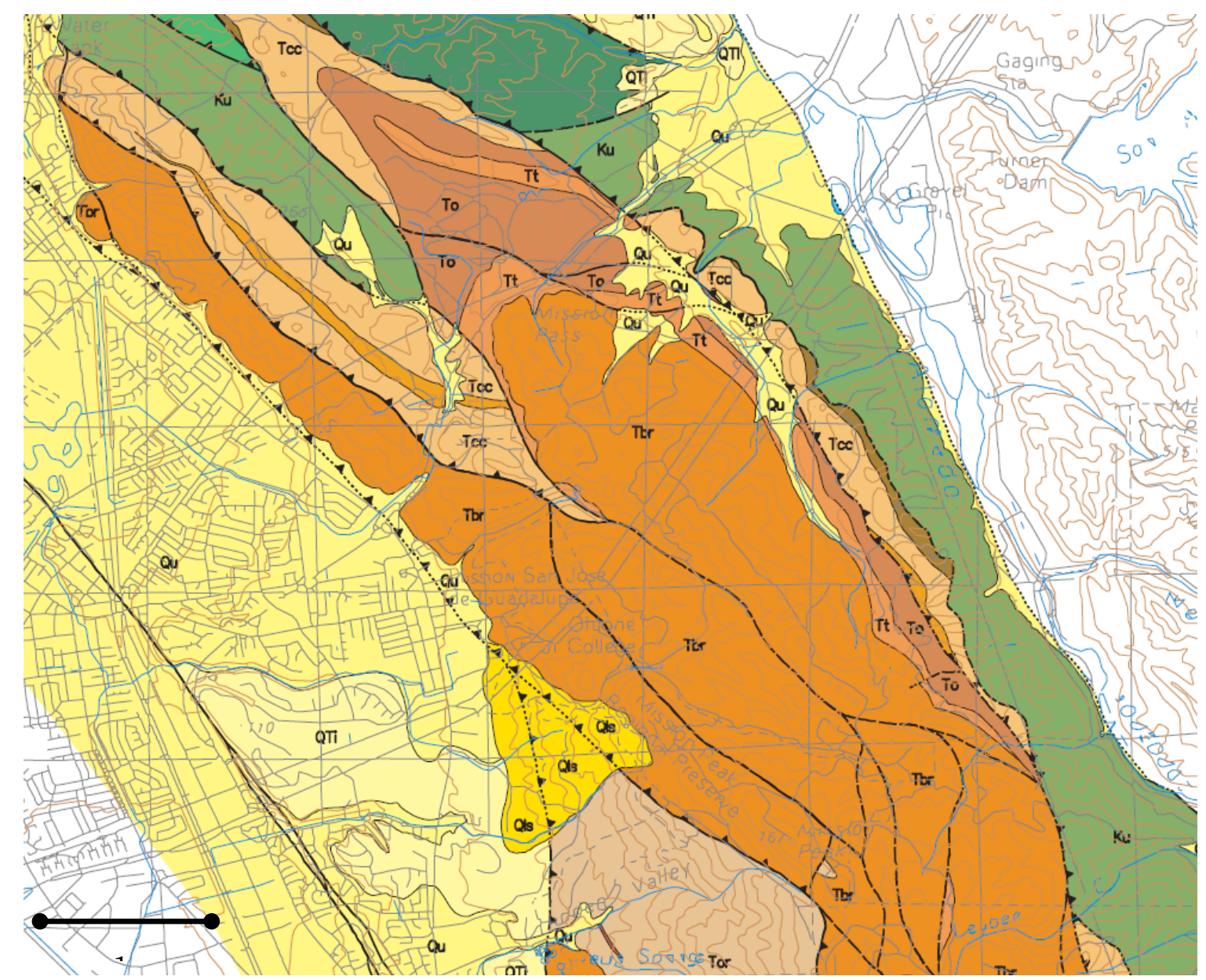

Figure A3-4 - Geologic map of Ohlone College and vicinity by Graymer et al, 1995

\section{Structures}

Hall, 1958 was the first to recognize the Mission Fault, a prominent boundary between the Briones sandstone exposed on Mission Peak and Mission Ridge, and the younger Pliocene-age non marine sedimentary rocks tightly folded in the overturned Tularcitos Syncline intermittently exposed beneath the more gently inclined slope. The Orinda beds are younger and less competent non marine sedimentary units, occupying a tightly folded prism extending southeasterly, from Mission San Jose. Because the Mission Fault is part of the stepover between the Hayward and Calaveras faults, the main feature are dominated by active thrust faults. The compression underling the Mission Fault is responsible for the uplift of Mission Hills at rate of $3 \mathrm{~mm} / \mathrm{year}$ with an estimate 1000 feet of separation between the Briones and Orinda formation based on topography and 
stratigraphy relationships (Rogers and Drumm). Microseismicity data studies by Ellswoth et al (1982) suggest that focal mechanism solutions for the Mission Fault indicated right-lateral slip on the seismically-defined fault plane, with one quake registering considerable thrust component.

Two fault branches were mapped in the campus. The westerly and less sinuous trace (also referred as the Warm Spring Fault) was interpreted as nearly vertical or steeply dipping to the northeast, while the more sinuous easterly trace was interpreted as a low-angle or reverse thrust fault.

\section{Hydrogeolgy}

The Ohlone College is part of the sub basin of the Niles Cones Ground Water Basin, located in the eastern side of the Hayward Fault in a zone called "above the fault"(Fig.A3-5). This zone is not in communication with aquifers in the west. The alluvium fan overlies the Santa Clara formation (Weiss Associates, 2009).

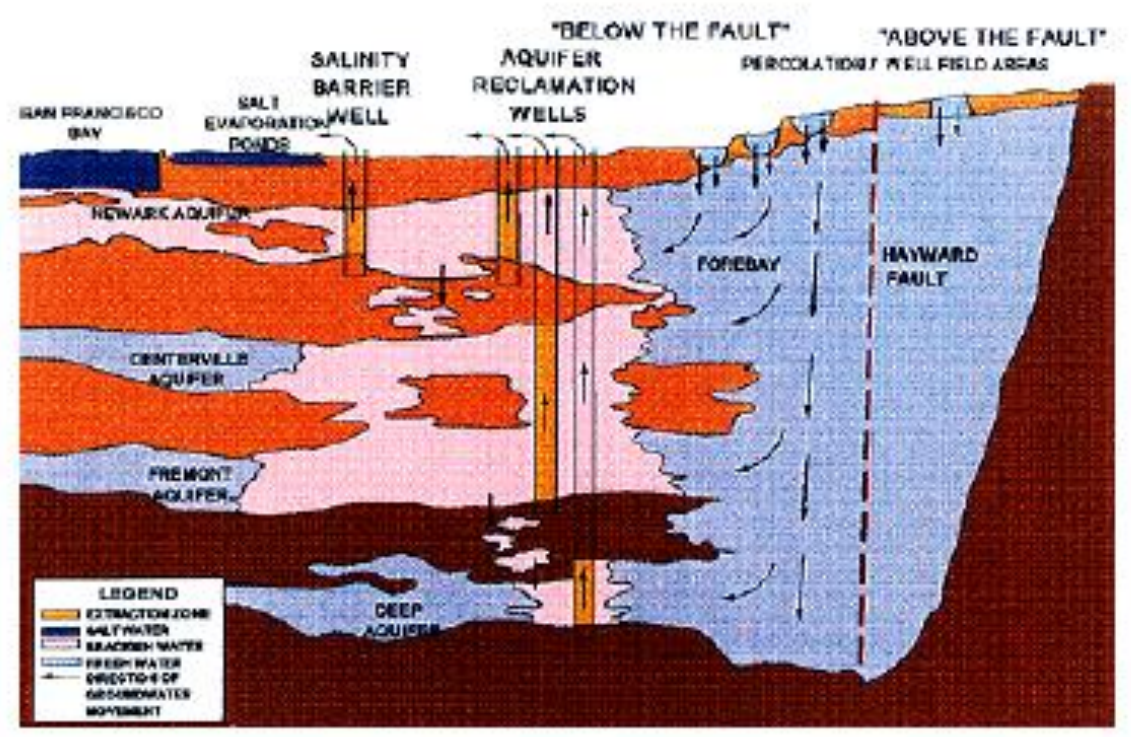

Figure A3-5 - Schematic Diagram of the Niles Cone Ground Water Basin, Southern San Francisco Bay Area, California 
Potentiometric maps of historic ground water indicate that the groundwater in the vicinity of the campus flowed approximately north-northeast to west southwest. The presence of springs also suggests that the fault may be the local ground water barrier. During six months, Weiss Associates, 2009 monitored the water level on a week day basis; however an existing extraction well (170 feet) was in place to dewater a construction site. A total of nineteen borings ( $\mathrm{P}$ series) were drilled at the site which six of them were test extraction wells located in the North, East and West of the campus. The test wells were installed to gather information on subsurface geology and hydrogeology. The depth of the boring varies between 30-70 feet below ground surface. Seasonal variation on groundwater level was observed with higher levels during rainy season.

A second set of boreholes, six W series, were drilled to collected core samples from depth between 90 and 100 feet (W -1 and W-2) and of 100- 238 feet (W3 through W-6) below sea level. Those cores were logged for lithological description, fracture analysis, core recovery information, and rock quality designation (RQD). Three of the cores (W-3, W-5 and W-6) were logged for geophysical data such as natural gamma-induction, electrical resistivity and acoustic televiewer logs. Fluid temperature and conductivity logs were performed in W-3 to identify potential permeable zones (Weiss Associates, 2009).

Groundwater elevations contours maps (for details see Weiss Associates, 2009) also showed fluctuations on groundwater levels during spring and summer, suggesting seasonal variations. The groundwater flow is generally directed to west or west-southwest from eleveation 470ft to $410 \mathrm{ft}$ (Weiss Associates, 2009).

Analyses of drill core by Weiss Associates, 2009 shows highly fractured zones at depth. Fracturing was characterized in the Briones sandstone by borehole televiewer and core logging. Major fracture zones were located about $125 \mathrm{ft}$ and $150 \mathrm{ft}$ and between $205 \mathrm{ft}$ and $213 \mathrm{ft}$ below the ground surface (Weiss Associates, 2009). 


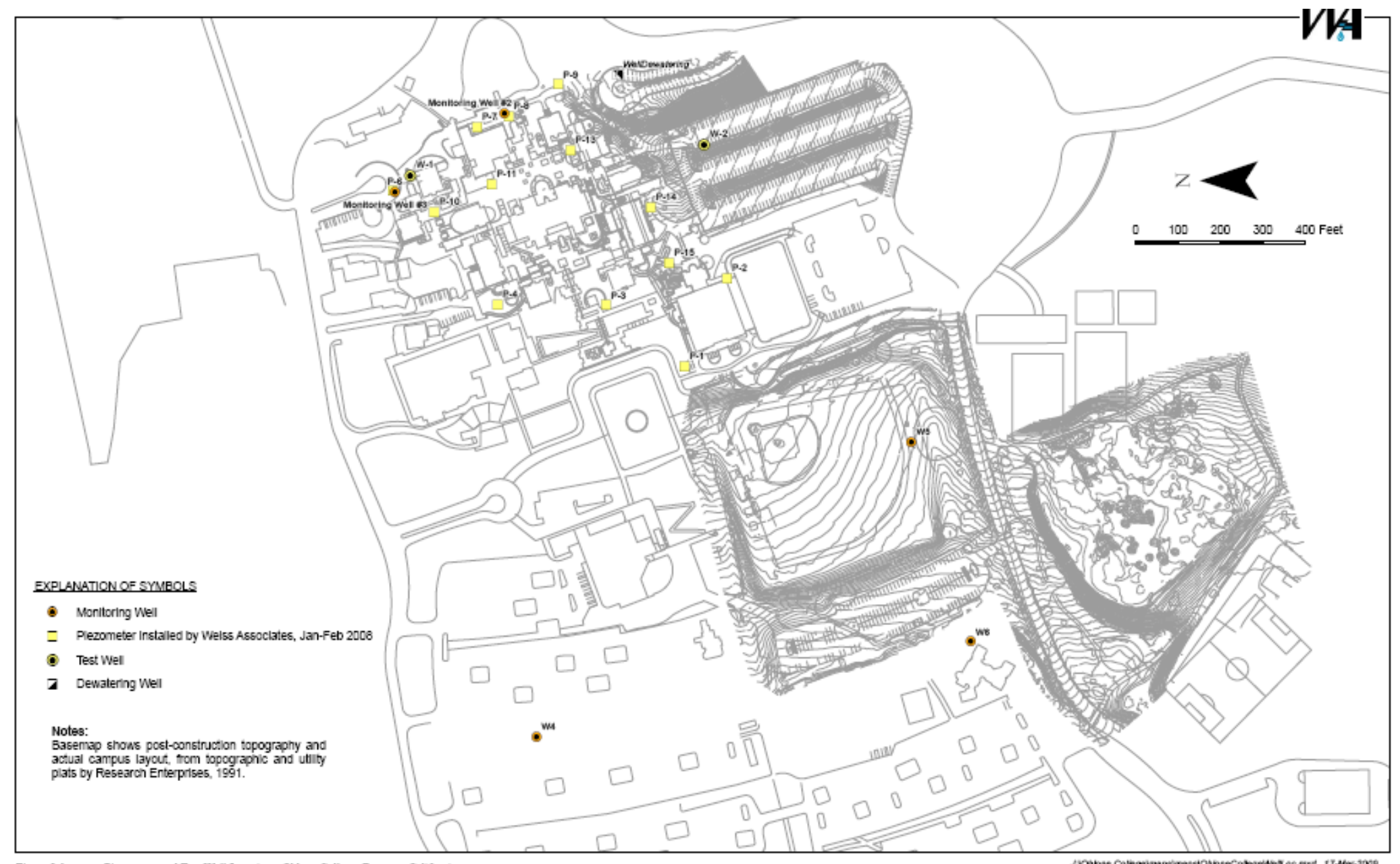

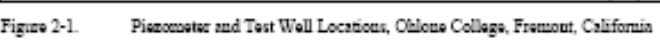

Figure A3- 6 - Piezometer and Test Well Locations, Ohlone College, Fremont, California (Weiss Associates, 2009) 


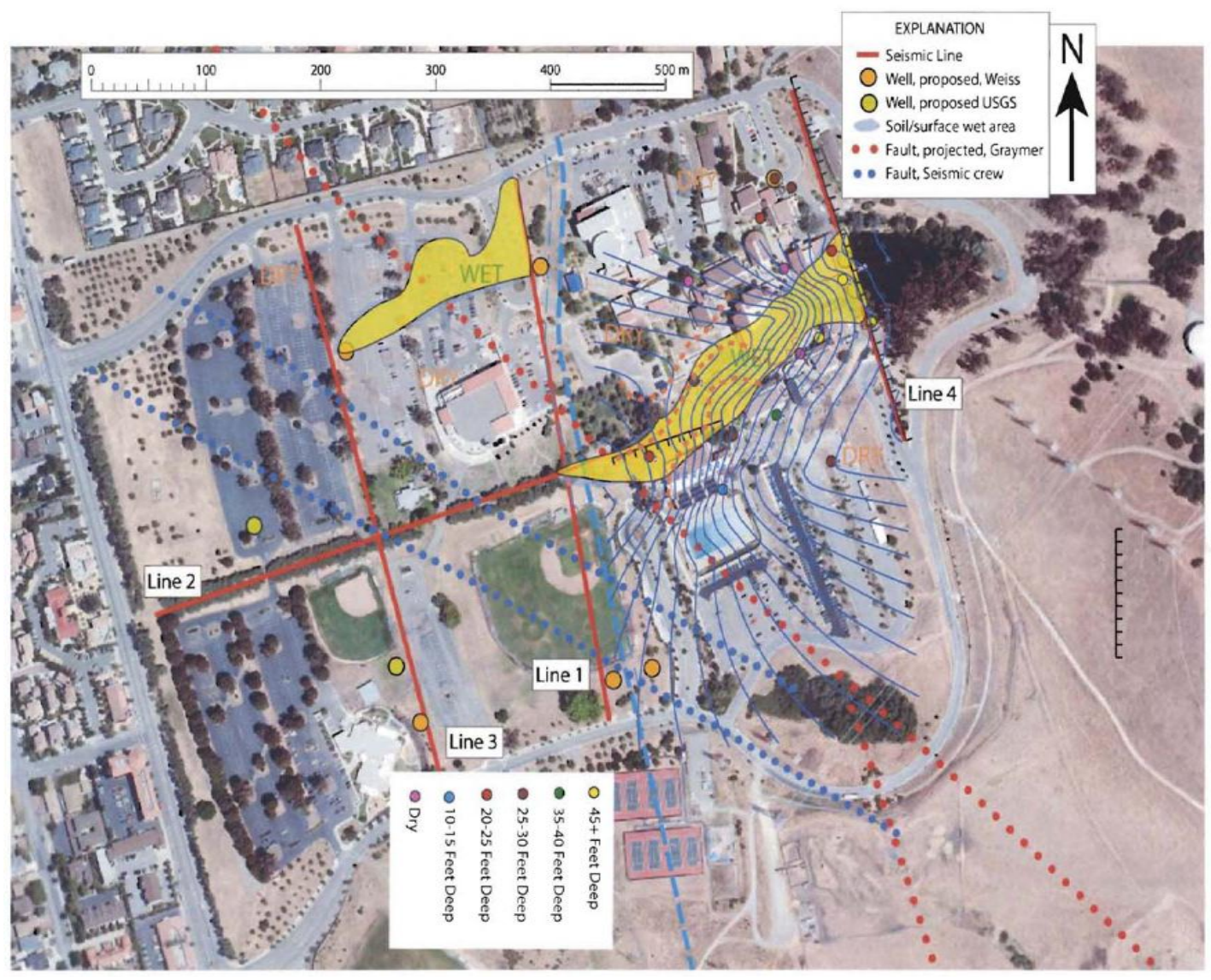

Figure A3-7 - Map showing location of historically wet areas subject to reservoir seepage,

Ohlone College, Fremont, California (Weiss Associates, 2009)

\section{Geophysics}

\section{Seismic Lines}

The subsurface hydrogeology structure was imaged by four geophysical lines, including reflection and refraction surveys. Data were acquired using a shoot-through acquisition technique and sources generated by the Betsy Seisgun and hammer. Seismic images included models of P-wave velocities, S-wave velocities, Vp/Vs ratios and Poisson' ratio

The fault trace was previously correlated with geomorphic features such as location of springs and alignment of trees (Weiss Associates, 2009). 
The seismic lines were aligned that Line 1, 3 and 4 are parallel to subparallel to each other and oriented approximately N-S. Line 2 is normal and crosses Line 1 and 3 (Fig.A3-8).

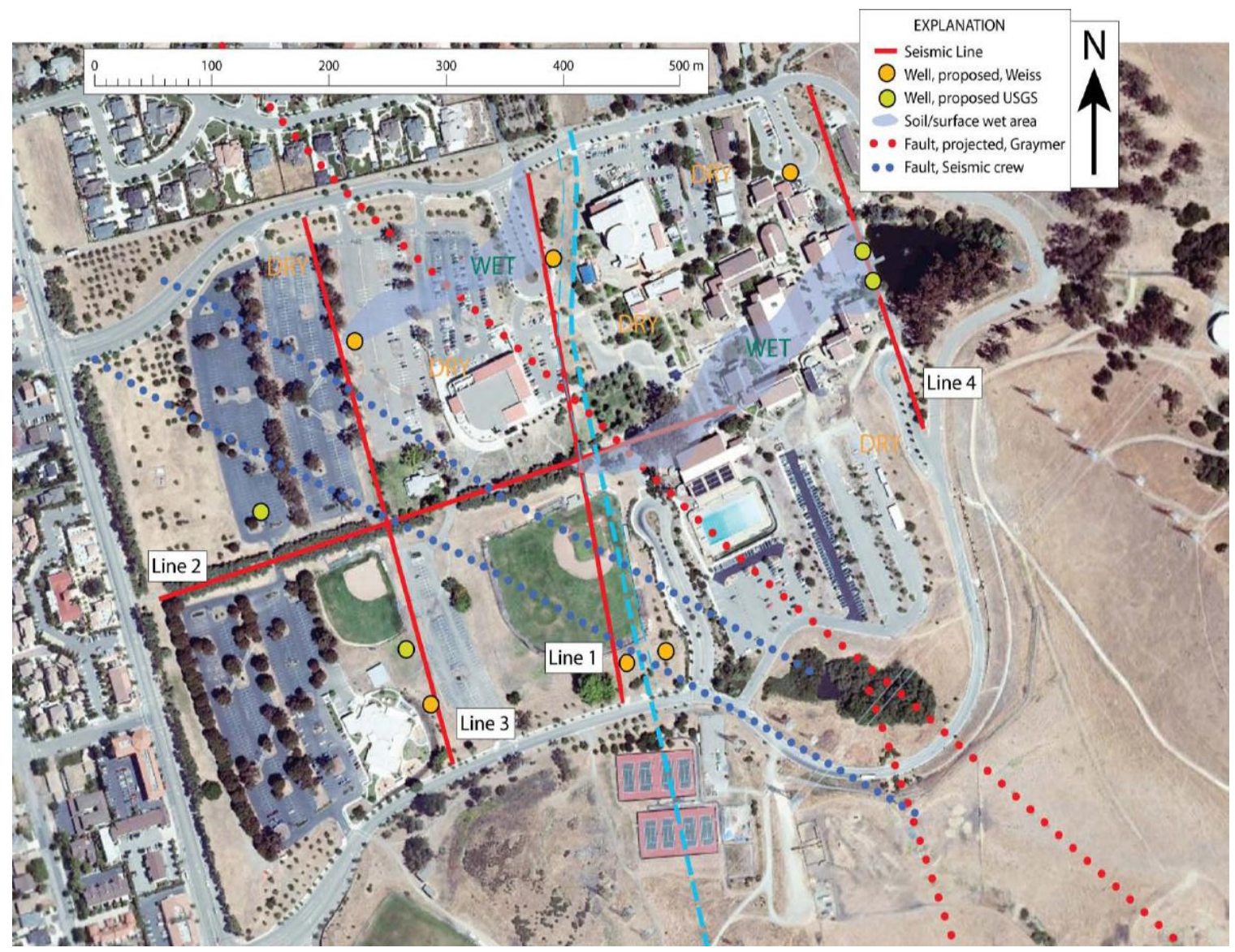

Figure A3-8 - The interpretation from the seismic lines suggests at least two surface fault expressions that trend across the western part of the Campus (Weiss Associates, 2009).

Fault zones are either expressed as low-velocity zones due to the damaged rock within fault zones or as an abrupt change in velocities across the fault zone (Aki and Lee, 1976; Mooney and Luetgert, 1982; Catchings et al., 2000 in Weiss Associates, 2009). On the Ohlone College Campus velocity images, a prominent northeasterly dipping low-velocity zone is observed along Profile 1 between meters 100 and 200 (distance) (Figure A3-9). At 
shallower depths on Profiles 2 and 3, the fault offsets relatively low-velocity rocks to the southwest from higher velocity rocks to the northeast. On seismic reflection images, faults are typically expressed by horizontal reflectors that are vertically offset across the fault zone. Along profile 1, the Ohlone College reflection image shows a prominent northeasterly dipping fault that corresponds to the low velocity zone seen in the velocity image. Similar offsets are seen along Profiles 2 and 3 along the northwestward extension of the fault. A similar, but less prominent fault is interpreted southwest of the fault described above. The USGS interprets these surface fault expressions (blue lines) to be the principal strands of the Mission Fault, which was mapped by Graymer et al., 2000 southeast of the Ohlone College Campus and projected to trend northwestward (red line) beneath the landslide deposits. Because of high noise levels, the velocity images generally show information in the upper 50-m depth range, and due to high dips in the underlying bedrock, the reflection data only provide clear images in low-angle unconsolidated sediments, which generally are less than about $40 \mathrm{~m}$ thick (Weiss Associates, 2009).

\section{Borehole Geophysics}

A second geophysical measurement came from borehole logging up to 200 feet depth in to the Briones sandstone. It suggested that fracture network in the Briones sandstone at depth was found to have a major influence on the hydrogeology in the campus. Major geophysical measurement included acoustical televiewer, electric conductivity logs, neutron and gamma-ray (Weiss Associates, 2009). 
Figure A3-9 - 3-D view of P-wave velocity models along lines 1-4, Ohlone College, Fremont, California (Weiss Associates, 2009)

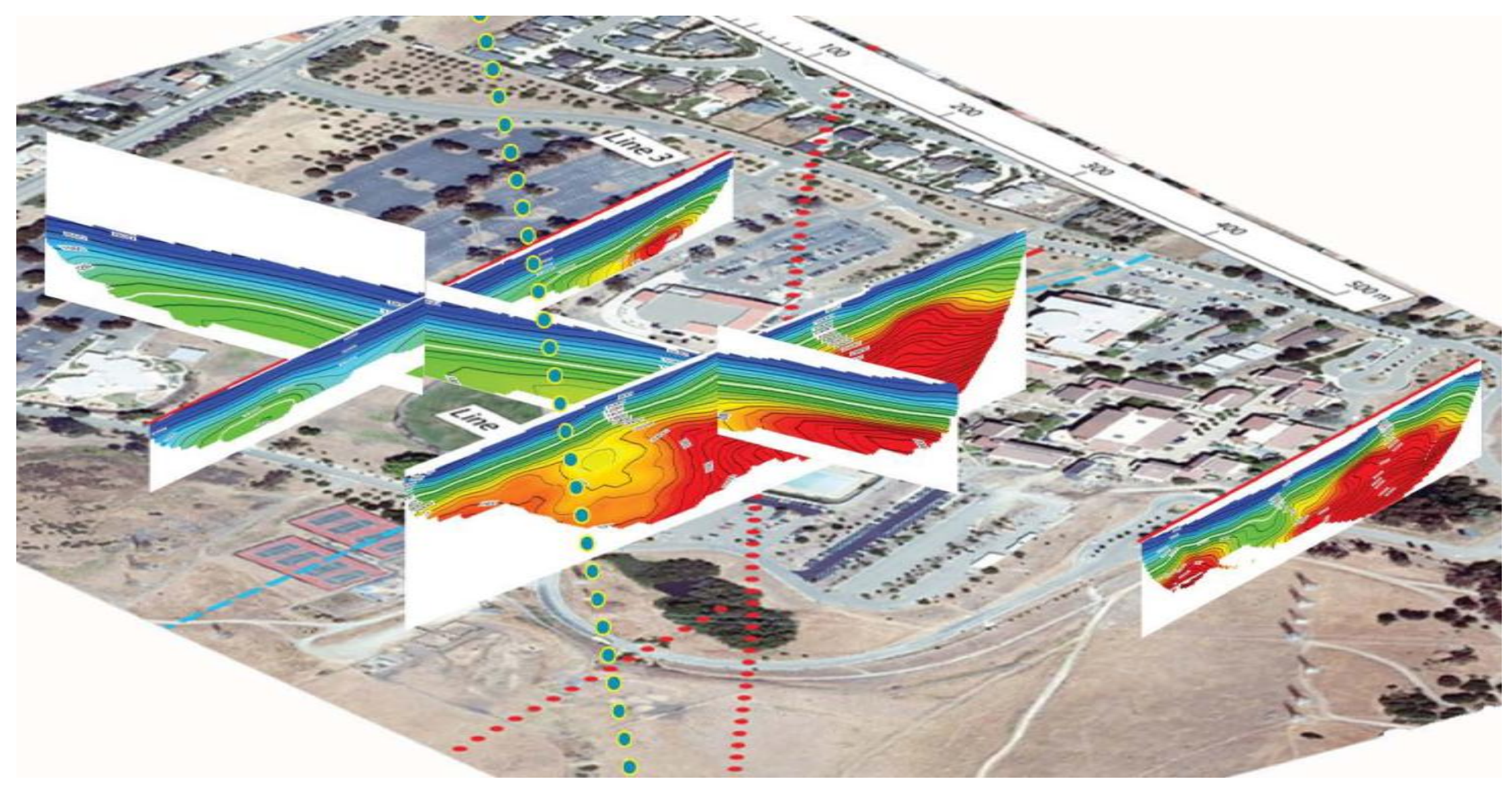




\section{Field Trip to Ohlone College on December 21, 2008}

On Saturday, December $21^{\text {th }}$, Dr. Tom Fogwell from Weiss Associates led a field trip to Oholone College. Participants included researchers from CRIEPI (Ueta, Hamada, Kanazawa, and Tanaka), NUMO (Goto), LBNL (Karasaki) and consulting (Onishi).

During this field trip, Dr. Fogwell explained the site geology, showed the location of surface springs and ponds, and the location of piezometers throughout the campus. Dr. Fogwell explained that the campus is located on the top of a shallow aquifer; and the main purpose of the present project was to develop a basic understanding of the hydrologic controls that determine the flow of groundwater on the campus. The fault does not have a surface expression but the presence of springs and water infiltration in the basement of buildings was causing structural damage. The topography clearly shows the hills on the eastern side of the campus and the groundwater flowing to the west. After examining the geological, hydrogeological and geophysical characteristics, Weiss Associates proposed having three extraction wells in the western edge of the campus. The water from these wells would be piped through a system of pipes using the effects of syphoning to assist the flow of the water. These pipes would route the extracted water around campus structures by using portions of an existing 36 inch diameter storm drainage system along the northern edge of the campus as a corridor for threading the pipes from the upper (eastern) part of the campus to the lower (western) part of the campus. It then would be connected at the lower part of the campus to a subsurface injection system consisting of non-perforated installed at approximately 30 feet below grade, and connecting to an infiltration gallery which will allow the water the re-enter the groundwater system. Details of can be found in Weiss Associates, 2009.

\section{Possible collaboration between LBNL and Weiss}

According to Dr. Fogwell, Weiss Associates is open for future collaboration on the Ohlone College project. The NUMO-LBNL project could take advantage of having a site where a well known fault exits and hydrogeological characterization is under way. The springs and ponds suggest that the fault is acting as barrier to the flow across it and the 
main flow pathway, according to Weiss Associates, 2009, is from the network fracture in the Briones sandstone. Further investigation on fault characteristics and hydrological monitoring would increase our knowledge on fault hydrology.

\section{Summary}

- Subsurface geology and hydrogeology of the site is quite complex due stepover between the Hayward and Calaveras Faults.

- It is a region of active faults (strike-slip and thrust) with micro-seismicity

- The area has active landslides due uplifting

- The water infiltration problem was solved by dewatering system in the east side of the campus.

- The combination of water level measurement and core samples showed a consistent pattern of fracturing at depth

- Seismic imaging suggests at least two surface expressions of the fault, crossing the western part of the campus.

- Fracture network in the Briones Formations at depth seems to be the main path of subsurface flow in the Ohlone College campus.

\section{References:}

Ellsworth, W.L., Olson, J.A., Shijo, L.N., and Marks, S.M., 1982, Seismicity and Active aults in the Eastern San Francisco Bay Region: in Hart, Hirshfeld and Schulz, eds., roceedings of the Conference on Earthquake Hazards in the Eastern S.F. Bay rea: CDMG Special Publication 62, p. 83-91.

Graymer, R.W., D.L. Jones, and E.E. Brabb, 1994. Preliminary Geologic Map of the iles 7.5 Minute Quadrangle, Alameda County, California. U.S. Geological Survey pen File Report 94-132. 
Graymer, R. W., D. L. Jones, and E. E. Brabb, 1995. Geology of the Hayward fault one: A digital map database, U.S. Geol. Surv. Open-File Rept. 95-597, 16 pp.

Graymer, R.W., D.L. Jones, and E.E. Brabb, 1996. Preliminary Geologic Map Emphasizing Bedrock Formations in Alameda County, California: A Digital Database. U.S. Geological Survey Open File Report 96-252.

Hall, C. A., 1958. Geology and paleontology of the Pleasanton area, Alameda and ontra Costa counties, University of California Press, 1 map, scale 1:40,000, 63 pp.

Jones, D. L., R. Graymer, C. Wang, T. V. McEvilly, and A. Lomax,1994. Neogene ranspressive evolution of the California Coast Ranges, Tectonics 13, no. 2, 561574.

Manaker, D.M., Michael, A.J. and Burgmann, R., 2005. Subsurface structure and inematics of the Calaveras- Hayward Fault stepover from three-dimensional Vp and Seismicity, San Francisco Bay Region, California. Bulletin of the seismological Society of America, 95, 2, 446-470

Rogers, J. David, and Patrick L. Drumm. Overview of the 1998 Mission Peak Landslide,Fremont,California.http:/web.mst.edu/ rodersda/hazard_mitigation_ techniques/landslides/Fremont/MP.htm

Weiss Associates, 2009. Progress report on groundwater intrusion abatement investigation for Ohlone College, Fremont, California. WA Project No. 344-1766, $480 \mathrm{p}$. 
Appendix 4

\section{NUMO LBNL Collaborative Project}

Development of Hydrologic Characterization Technology of Fault Zones

Work Plan

August 2008 


\section{Background and objectives:}

As outlined in the Project Plan, starting from FY2007 for duration of five years, this project seeks to establish effective and efficient investigation and characterization technologies for estimation of hydrologic properties of fault zones at the preliminary characterization stage followed by field tests to validate their effectiveness. In particular, the methodology development will focus on the use of hydrologic investigation and characterization technologies that incorporate the relationship between geologic and hydrologic characteristics of fault zones.

In FY2007, literature survey was conducted from various countries in the world including Japan in an effort to develop classification of faults based on geologic and hydrologic properties. Literature survey was conducted on published investigation and characterization technologies as well. Based on the results of the survey, a flow of investigation and characterization steps as well as the plans for filed validation program were developed. The literature survey on the fault zone classification revealed that there is no clear and direct relationship between the sense of displacement (normal, reverse and side-slip) and the hydrologic properties. However, it was concluded that it may be still possible to indirectly estimate the hydrologic properties of faults from geologic characteristics based on a classification by other geologic attributes. As for the literature search on investigation and characterization technologies, a comprehensive summary of geological, geophysical, hydrological and geochemical techniques that have been used at investigation sites in various countries was presented. A tentative and generic flow chart for site investigation steps was compiled. Information from three field sites in the United States was collected and investigated as potential sites for field validation exercise. A site with known faults within LBNL property was selected as an investigation site and an outline field investigation plan was drawn. Scientists with expertise in structural geology and hydrology evaluated these results and concluded that further efforts should be expended to develop fault-type classification from different viewpoints. And that there is very few field examples of hydrologic characterization of fault zones and that it is important to validate and establish characterization technologies by conducting investigation at a field site.

In FY2008, based on the 5-year project plan and on the results of the FY2007 effort, additional literature survey will be conducted to establish the procedure for investigation and characterization of fault zone hydrology with a consideration for potential relationship between geologic and hydrologic characteristics. In addition, as a part of the site investigation and validation project at the LBNL site, surface-based investigations will be conducted to understand the geologic characteristics and to construct drilling plan at the site. 


\section{Activities:}

The work activities planned for FY2008 is outlined below. A detailed plan for each investigation activity will be developed separately.

\section{Literature survey}

1.1 Investigation of the relationship between geologic and hydrologic characteristics (Domestic outsourcing)

Building on the FY2007 results, the relationship between geologic and hydrologic characteristics will be investigated based on different attributes from the previous year while using more detailed information from Japan and from literature that does not discuss hydrologic information and attempts will be made to classify fault zone hydrology.

1.2 Procedure development for investigation and characterization (Domestic outsourcing)

Based on the results of 1.1 and the Improvement and Systematization Project, the procedure that was developed in the previous year will be modified to match the style of Japanese investigation and characterization, and compile information to ultimately develop the methodology for investigation and characterization of hydrologic properties of fault zones.

2 Field investigation

2.1 Evaluation of existing information

\subsubsection{Aerial photo analysis (Domestic outsourcing)}

Using Japan's unique analysis techniques of aerial photometry, the faults at the LBNL site will be analyzed to define them in relation to the regional faulting system, the relationship to the nearby active fault, and their geometric features to provide information for building a model to be used to design borehole drilling and testing.

\subsubsection{Analysis of site information}

Available relevant information and data regarding the site geology, structure, hydrology and geochemistry at the LBNL site will be streamlined and analyzed and the most up-to-date conceptual model of the site geology, hydrology and geochemistry will be constructed. At the same time the location and the properties of faults will be estimated and incorporated in the model.

\subsection{Surface-based investigation plan}

Using available data and information and the results of the analysis of 2.1, designs for geophysics, surface-geological survey, trenching and analysis of 
groundwater will be developed and a detailed plan will be developed for each investigation activity.

\subsection{Surface-based investigation}

\subsubsection{Geophysical survey}

Taking into account the rock types and the real estate of the LBNL site, as many as three lines of electromagnetic survey (CSEM) and an electrical survey (resistivity, SP) will be conducted to estimate the geometry and the properties of the fault. If the resources and schedule allow, reflection seismic surveys will be conducted using an appropriate source.

\subsubsection{Surface geologic survey}

Geological mapping will be conducted centered around the location of the fault based on the available information and the results of the geophysical surveys. The surface petrology, deposits, and the distribution of factures and the location of the fault will be analyzed. If the fault is exposed, a detailed sketch will be made and notes will be taken. If appropriate, thin sections of rock samples will be made and microscopic, chemical and dating analyses will be conducted to understand the properties of the fault and the protolith.

\subsubsection{Trench studies}

Up to three trenches will be excavated at locations guided by the geophysical and geological surveys with a maximum length of $30 \mathrm{~m}$ and a width of $2.5 \mathrm{~m}$. The walls of the trenches will be mapped and detailed field notes will be taken including the strike, dip, the sense and the amount of displacement, deformation structure, protolith rock types, stratigraphy, metamorphism(secondary minerals and veins). If appropriate, thin sections of rock samples will be made and microscopic, chemical and dating analyses will be conducted to understand the properties of the fault and the protolith.

\subsubsection{Structural analysis of faults (Domestic outsourcing)}

Rock samples of the fault obtained from the surface survey and trenching will be analyzed using the $\mathrm{CT}$ and polished surface analysis techniques developed uniquely in Japan to understand detailed geologic properties such as the structure and deformation history of the fault.

\subsubsection{Groundwater geochemical analysis}

If deemed necessary based on the analysis of existing data and the surface geological survey described above, analyses of groundwater from the wells and streams in and near the site will be conducted to understand the chemistry, isotopes, and groundwater ages.

2.4 Analysis and evaluation of results 


\subsubsection{Hydrologic and geochemical analysis (Domestic outsourcing)}

Using the methodology developed by NUMO under the Improvement Project, the pre-existing information as well as the data from the surface investigation of the hydrologic and geochemical properties of the groundwater at the LBNL site will be analyzed and evaluated to streamline the information for model development and analysis for the planning of the drilling and testing program.

2.4.2 Analysis and evaluation of literature and surface investigation results

All the information from the literature survey and surface investigation will be integrated and the location and the properties of the fault will be reevaluated. The conceptual model will be updated accordingly. The feasibility of going forward with the plan to conduct borehole based investigation at the LBNL site will be evaluated. If deemed appropriate, the geologic, hydrologic and geochemical conceptual model will be updated and a three dimensional hydro-geologic model will be constructed and groundwater flow analysis will be conducted. If deemed the site is unfeasible, the work plan will be reevaluated and an alternative site will be considered.

\subsection{Planning of borehole-based investigation}

If the fault at the LBNL site is deemed appropriate for validation of the fault zone investigation and characterization technology, a comprehensive plan for drilling and testing will be formulated that will span for additional three years starting from FY2009 with multiple boreholes to be drilled.

3 Discussion of results and reporting

The results of the project will be discussed involving experts of hydrology and faults from domestic universities and research institutes for more technical and objective evaluation. A report will be prepared that summarizes the results of the discussion as well as the results from the FY2008 activity.

\section{Division of work and implementation structure}

NUMO and LBNL will collaborate in planning all parts of the work and evaluation of the results. Literature survey and site investigation activity will be split between NUMO and LBNL as shown in Table 1. Some portion of NUMO work that cannot be conducted directly by NUMO will be outsourced either to a domestic institution or to LBNL (Figure 1). 
Table 1: Work responsibility schedule for FY2008

\begin{tabular}{|c|c|c|c|c|c|c|}
\hline \multirow[b]{2}{*}{ FY2008 Work Item } & \multirow[b]{2}{*}{ Activity } & \multirow[b]{2}{*}{ Objective } & \multicolumn{3}{|c|}{ NUMO } & \multirow{2}{*}{$\begin{array}{l}\text { LBNL } \\
\text { Direct }\end{array}$} \\
\hline & & & Direct & $\begin{array}{c}\text { LBNL } \\
\text { contract }\end{array}$ & $\begin{array}{l}\text { Domestic } \\
\text { contractor }\end{array}$ & \\
\hline \multicolumn{7}{|c|}{ Literature survey } \\
\hline $\begin{array}{c}\text { Fault type } \\
\text { classification }\end{array}$ & $\begin{array}{l}\text { Collect and analyze } \\
\text { literature info }\end{array}$ & $\begin{array}{l}\text { Improve investigation and } \\
\text { characterization flow }\end{array}$ & & & $\bigcirc$ & \\
\hline Characterization flow & $\begin{array}{c}\text { Improve and } \\
\text { systematize flow }\end{array}$ & Develop methodology & & & $\bigcirc$ & \\
\hline \multicolumn{7}{|c|}{ Site Investigation } \\
\hline \multirow[t]{2}{*}{$\begin{array}{l}\text { Analysis of existing } \\
\text { info }\end{array}$} & Analyze aerial photo & $\begin{array}{c}\text { Estimate fault properties in } \\
\text { relation to the active fault }\end{array}$ & & & O & \\
\hline & $\begin{array}{c}\text { Collect \& analyze site } \\
\text { info } \\
\text { (literature, analysis; } \\
\text { construct geo, hydro, } \\
\text { geochem model }\end{array}$ & $\begin{array}{c}\text { Estimate geol., hydrol., } \\
\text { geochem properties } \\
\text { Location, property of fault } \\
\text { Plan surface invest, drilling } \\
\text { plan }\end{array}$ & & $\bigcirc$ & & $\bigcirc$ \\
\hline $\begin{array}{l}\text { Plan surface } \\
\text { investigation }\end{array}$ & $\begin{array}{c}\text { Design and plan work } \\
\text { activity }\end{array}$ & \begin{tabular}{|c|}
$\begin{array}{c}\text { Conduct surface } \\
\text { investigation and } \\
\text { characterization }\end{array}$ \\
\end{tabular} & $\bigcirc$ & & & $\bigcirc$ \\
\hline \multirow[t]{5}{*}{ Surface investigation } & Geophysics & $\begin{array}{c}\text { Location and properties of } \\
\text { fault }\end{array}$ & & $\bigcirc$ & & $\bigcirc$ \\
\hline & Surface geology & $\begin{array}{c}\text { Site geology } \\
\begin{array}{c}\text { Location and properties of } \\
\text { fault }\end{array} \\
\text { Hydrologic properties of } \\
\text { fault }\end{array}$ & & $\bigcirc$ & & $\bigcirc$ \\
\hline & Trenching & $\begin{array}{c}\text { Location and properties of } \\
\text { fault } \\
\begin{array}{c}\text { Hydrologic properties of } \\
\text { fault }\end{array}\end{array}$ & & $\bigcirc$ & & $\bigcirc$ \\
\hline & Fault structural analysis & $\begin{array}{l}\text { Detailed geologic } \\
\text { properties of fault }\end{array}$ & & & $\bigcirc$ & \\
\hline & Geochemical analysis & $\begin{array}{l}\text { Hydrol. and geochemical } \\
\text { properties of site and fault }\end{array}$ & & $\bigcirc$ & & O \\
\hline \multirow[t]{2}{*}{$\begin{array}{l}\text { Analysis and } \\
\text { evaluation }\end{array}$} & $\begin{array}{c}\text { Analyze hydrologic and } \\
\text { geochemical data }\end{array}$ & $\begin{array}{c}\text { Evaluate hydro., geochem } \\
\text { characterization using } \\
\text { results from Sophistication } \\
\text { Project }\end{array}$ & & & $\bigcirc$ & \\
\hline & \begin{tabular}{|} 
Analysis and evaluation \\
of literature and surface \\
investigation (geol., \\
hydrol., geochem. \\
model development, \\
groundwater flow \\
analysis
\end{tabular} & $\begin{array}{c}\text { Site geol., } \\
\text { hydrol.,geochem. } \\
\text { Properties } \\
\text { Location and properties of } \\
\text { fault } \\
\text { Develop drilling and testing } \\
\text { plan }\end{array}$ & $\bigcirc$ & 0 & & $\bigcirc$ \\
\hline $\begin{array}{l}\text { Develop drilling and } \\
\text { testing plan }\end{array}$ & $\begin{array}{c}\text { Design and develop } \\
\text { work plan }\end{array}$ & $\begin{array}{l}\text { Conduct and evaluate } \\
\text { borehole based tests }\end{array}$ & $\bigcirc$ & & & $\bigcirc$ \\
\hline
\end{tabular}




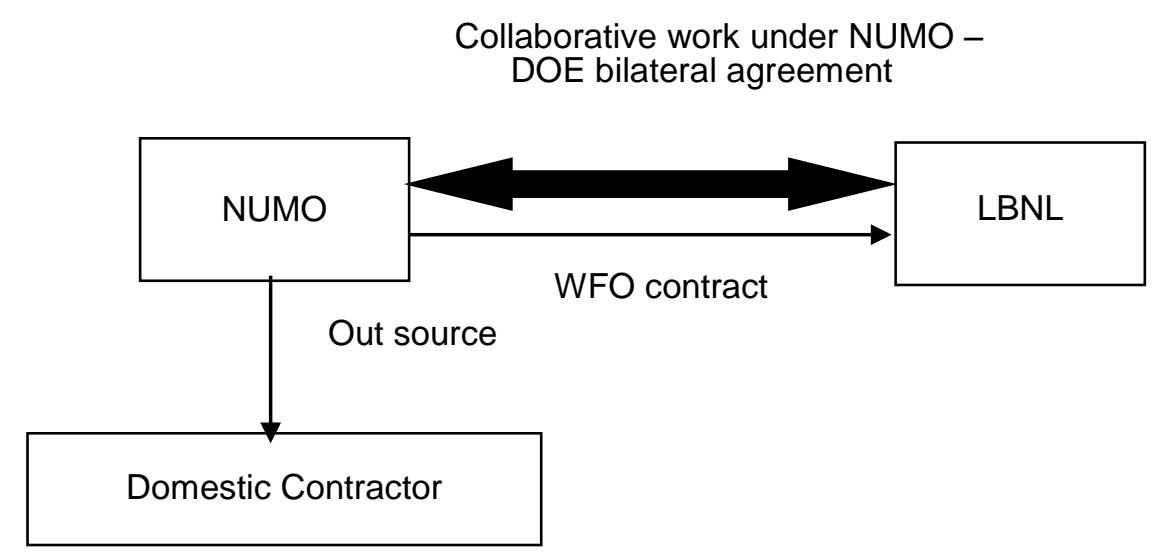

Figure 1. Execution and contract structure

\section{Schedule and Deliverables}

The duration of the collaborative work for FY2008 will be from the date contract will have signed until March 31st, 2009. Table 2 shows the work schedule, Table 3 lists the deliverables. The due date of the deliverables is March 16 th 2009.

Table 2: Project schedule for FY2008 activities

\begin{tabular}{|c|c|c|c|c|c|c|c|c|}
\hline \multirow{2}{*}{ 1. Literature survey } & 8 & 9 & 10 & 11 & 12 & $2009 / 1$ & 2 & 3 \\
\hline & & & & & & & & \\
\hline Fault type classification (DO) & & & & & & & & \\
\hline $\begin{array}{l}\text { Examine investigation\& char. } \\
\text { Flow (DO) }\end{array}$ & & & & & & & & \\
\hline 2. Field investigation & & & & & & & & \\
\hline Aerial photo analysis (DO) & & & & $\longrightarrow$ & & & & \\
\hline Collect site info \& analysis & & & & & & & & \\
\hline $\begin{array}{l}\text { Develop surface investigation } \\
\text { plan }\end{array}$ & & & & & & & & \\
\hline Geophysics & & & & & & & & \\
\hline Surface geologic survey & 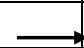 & & & $\longrightarrow$ & & & & \\
\hline Trenching & & & & & & & & \\
\hline $\begin{array}{l}\text { Sophisticated fault structural } \\
\text { analysis }\end{array}$ & & & & & & & & \\
\hline $\begin{array}{l}\text { Groundwater chemistry } \\
\text { analysis }\end{array}$ & & & & & & & & \\
\hline $\begin{array}{l}\text { Hyrol., geochem. data analysis } \\
\text { (DO) }\end{array}$ & & & & & & & & \\
\hline $\begin{array}{l}\text { Analysis of Literature and } \\
\text { surface investigation }\end{array}$ & & & & & & & & \\
\hline $\begin{array}{l}\text { Develop borehole-based } \\
\text { investigation program }\end{array}$ & & & & & & & & \\
\hline 3. Deliverables & & & & & & & & \\
\hline Write Reports & & & & & & & & \\
\hline Meetings $(\triangle:$ LBNL, $\boldsymbol{\Delta}:$ JPN $)$ & & & & & & & & \\
\hline
\end{tabular}


Table 3: List of deliverables

\begin{tabular}{|c|c|c|c|l|}
\hline Deliverable & Due Date & Send to: & No. of Copies & \multicolumn{1}{|c|}{ Notes } \\
\hline \hline FY2008 final report & March $16^{\text {th }} 2009$ & $\begin{array}{l}\text { Science and } \\
\text { Technology Dept. }\end{array}$ & 1 & Hard copy \\
\hline $\begin{array}{l}\text { Electronic file of the } \\
\text { final report }\end{array}$ & March $16^{\text {th }} 2009$ & $\begin{array}{l}\text { Science and } \\
\text { Technology Dept. }\end{array}$ & 1 & $\begin{array}{l}\text { PDF and Microsoft } \\
\text { Word format on } \\
\text { CD(s) or DVD(s) }\end{array}$ \\
\hline
\end{tabular}

